\title{
EDUCAÇÃO A DISTÂNCIA NO ENSINO SUPERIOR
}

Ensino hibrido

cajuluína

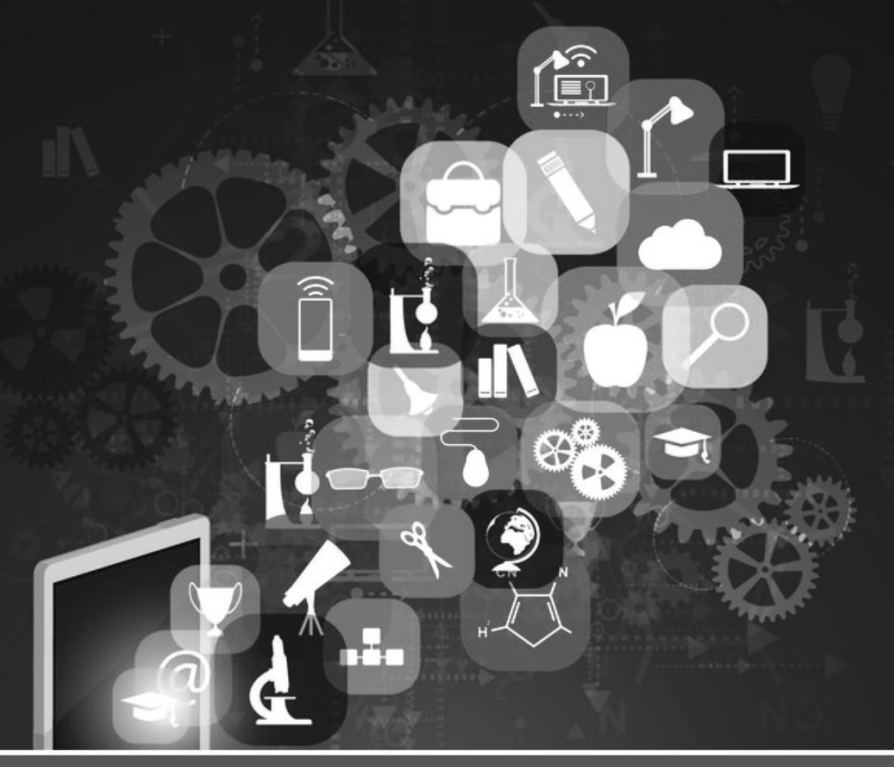

KÁTIA CILENE SILVA

QUERTE TERESINHA CONZI MEHLECKE ORGANIZADORAS 
Série Ead no ensino superior - v. 4 Coordenação: Querte Teresinha Conzi Mehlecke 


\section{KÁTIA CILENE DA SILVA \\ QUERTE MEHLECKE \\ [ORGANIZADORAS]}

Ana Karine das Chagas Vieira Antônio Soares de Oliveira Filho

Cláudia Magalhães

Cristiane Kessler de Oliveira

Danniel Cavalcante Lopes

Enoy Fernandes Pimenta

Ernandes Rodrigues do Nascimento Jéssica Ester Frutuoso de Souza

João Padilha Moreira José Wilson Cavalcante Júnior Josivania Maria Alves de Freitas

Leandro Krug Wives

Luiz Leonardo Nascimento Denicol
Luiza Helena Felix de Andrade

Marcos Evandro Cintra

Maria Auxiliadora Soares Padilha

Michela Melo da Silva

Mylani Nathalini Dantas Costa

Neferson Barbosa da Silva Ramos

Nelson Luis Eufrasio Junior

Rafael Lira

Renata Araújo

Roges Horácio Grandi

Rosangela Gonçalves dos Santos

Ulisses de Melo Furtado

\section{EDUCAÇÃO A DISTÂNCIA NO ENSINO SUPERIOR:}

Ensince hierida

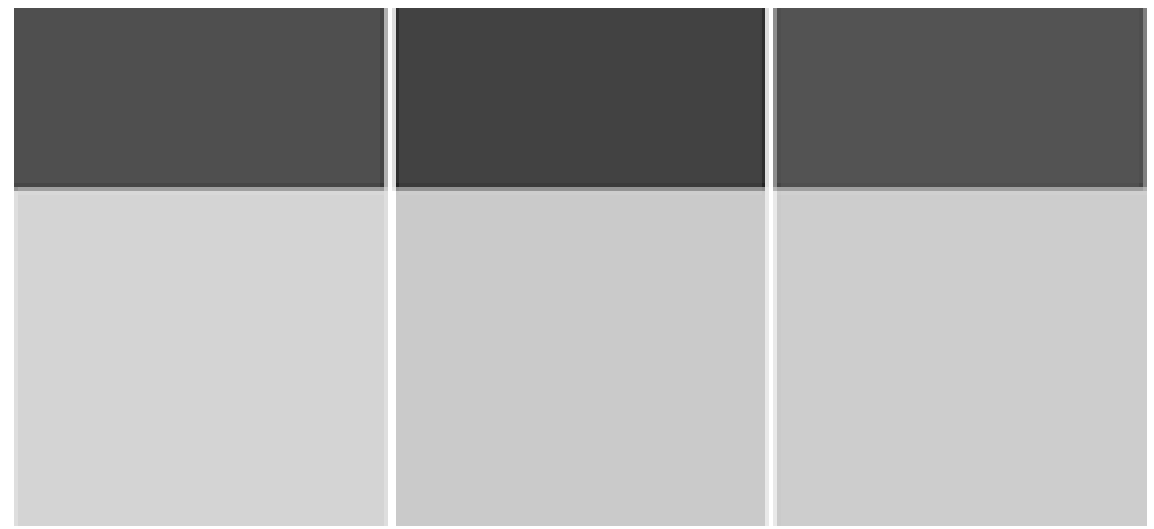


Copyright by @ 2019

Vários autores

COORDENAÇÃo EDITORIAL:

Wilbett Oliveira

EDITORAÇão ELETRÔNICA:

Semadar Edições

REVISÃo:

Dos autores

$1^{2}$ edição

Conselho Editorial

Dra. Querte Teresinha Conzi Mehlecke (UFRGS)

Dra. Susane Garrido (UFRGS)

Dra. Kátia Cilene da Silva (UFPE)

Dra. Isolina Oliveira (Universidade de Lisboa)

Dra. Maria Auxiliadora S. Padilha (UFPE)

É proibida a reprodução total ou parcial desta obra, por qualquer meio e para qualquer fim, sem a autorização prévia, por escrito, dos autores.

Obra protegida pela Lei de Direitos Autorais

[CIP-Brasil]

Catalogação na Publicação

Silva , Kátia Cilene da.

SI586e Educação a distância no ensino superior: ensino híbrido. Kátia Cilene da Silva /

Querte Teresinha Conzi Mehlecke [Organizadoras]. São Paulo: Opção livros, 2019. Série $\mathrm{EaD}$ em debate, v. 4.

ISBN: 978-85-8305-150-3

1. Educação 2. Ensino a distância. 3. Ensino superior 4. Ensino híbrido

I. Título. II. Kátia Cilene da Silva III. Querte Teresinha Conzi Mehlecke

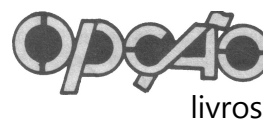

Av. Eng. Luis Carlos Berrini, 1140 - $7^{\circ}$ Andar

Brooklin - São Paulo, SP - CEP: 04571-000

Home page: www.opcaolivros.com.br

Email: contato@opcaoeditora.com

Telefones: (11) 4777-0123 


\section{SUMÁRIO}

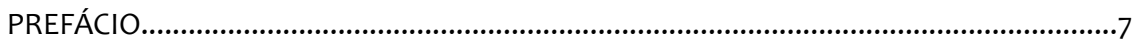

10 ASSISTENTE A DOCÊNCIA DOS POLOS DA UNIVERSIDADE ABERTA

DO BRASIL: UM ATOR PARA POTENCIALIZAR O ENSINO HÍBRIDO...........................9

Mylani Nathalini Dantas Costa

2 BLENDED LEARNING NA EDUCAÇÃO SUPERIOR: UMA EXPERIÊNCIA

DE ENGAJAMENTO DOS ALUNOS DO CURSO DE CIÊNCIA DA COMPUTAÇÃO.

Danniel Cavalcante Lopes - Kátia Cilene da Silva

3 BLENDED LEARNING EM LICENCIATURAS DE ENSINO DE CIÊNCIAS

E COMPUTAÇÃO

.31

Kátia Cilene Silva - Rosângela Gonçalves dos Santos

Ana Karine das Chagas Vieira - Michela Melo da Silva

4 PROJETOS EDUCACIONAIS NA EAD: ORGANIZAÇÃO E PRÁTICA

NA EDUCAÇÃO ESCOLAR INDÍGENA EM PERNAMBUCO.

Josivania Maria Alves de Freitas

5 AMBIENTE VIRTUAL DE APRENDIZAGEM EM DISCIPLINAS PRESENCIAIS

NO ENSINO SUPERIOR: UM EXEMPLO COM O GOOGLE CLASSROOM

Ernandes Rodrigues do Nascimento - Maria Auxiliadora Soares Padilha

6 UMA PROPOSTA DE APRIMORAMENTO DOS XMOOCS POR MEIO

DE FOCO NA PESSOA E NAS INTERAÇÕES SOCIOAFETIVAS.

Roges H. Grandi - Leandro K. Wives

7 ENSINO HÍBRIDO COMO DESENHO DE CAMINHO ALTERNATIVO

PARA A EDUCAÇÃO CONTINUADA NA SAÚDE.

Nelson Luís Eufrásio Junior

8 EXPERIÊNCIA EM METODOLOGIAS ATIVAS EM SALA DE AULA

NO ENSINO SUPERIOR

Cristiane Kessler de Oliveira - João Padilha Moreira

Luiz Leonardo Nascimento Denicol - Querte Teresinha C. Mehlecke

9 ABORDAGENS HÍBRIDAS NA EAD: O PIBID COMO ESTRATÉGIA DE PERMANÊNCIA PARA OS ALUNOS DA LICENCIATURA EM MATEMÁTICA.............125

Kátia Cilene da Silva - Luiza Helena F. de Andrade - Ulisses de M. Furtado 
10 O USO DA MÉTODO HÍBRIDA COMO POSSIBILIDADE DIDÁTICA

MOTIVADORA DE APRENDIZAGEM NA EDUCAÇÃO BÁSICA.

Antônio Soares de Oliveira Filho - Kátia Cilene da Silva

11 BRINC@RTE: A ARTEE O BRINCAR COMO EXPERIÊNCIA

INTERDISCIPLINAR NA EAD

Renata Araújo - Cláudia Magalhães - Rafael Lira

12 APLICAÇÕES DA INTELIGÊNCIA ARTIFICIAL NA RESOLUÇÃO DE PROBLEMAS CLÁSSICOS

DA EDUCAÇÃO A DISTÂNCIA.

Jéssica Ester Frutuoso de Souza - Kátia Cilene da Silva

Danniel Cavalcante Lopes - Marcos Evandro Cintra

13 O ENSINO HÍBRIDO POTENCIALIZANDO O USO DE TICS PARA ALÉM DOS MUROS

DAESCOLA. .201

José Wilson Cavalcante Júnior - Kátia Cilene da Silva

14 O PROINFO COMO ABORDAGEM HÍBRIDA DE FORMAÇÃO CONTINUADA:

O IMPACTO DAS TICS E A RELEVÂNCIA QUE PROFESSORES CAPACITADOS

PARA USÁ-LAS PODEM PROPORCIONAR À EDUCAÇÃO.

Enoy Fernandes Pimenta - Kátia Cilene da Silva

15 REDE COLABORATIVA DE INOVAÇÃO TECNOLÓGICA NA EDUCAÇÃO:

COMPARTILHANDO CONHECIMENTOS A PARTIR DA APRENDIZAGEM

NA ERA DIGITAL

Querte Mehlecke - Neferson Barbosa da S. Ramos

Maria Auxiliadora S. Padilha

SOBRE OS AUTORES 


\section{PREFÁCIO}

$\mathrm{Na}$ sociedade conectada em que vivemos, desde o advento da internet, repletos de mudanças constantes, no modo de vida das pessoas, quebrando fronteiras e distâncias geográficas, por meio da possibilidade de comunicação em tempo real, em que o avanço tecnológico impulsiona a busca permanente de novas e adaptadas formas de motivar e mover indivíduos, primando pela interação, pelo compartilhamento de ideias e conhecimentos.

$\mathrm{Na}$ história da humanidade é constante a descoberta e complexificação do conhecimento, desde a Revolução Industrial, permeando a criatividade, experimentando o lúdico, seja com a utilização de jogos digitais ou de cenários alternados baseados em realidade virtual e inteligência artificial.

O saber e o fazer docente se fundem na perspectiva da utilização de recursos das TICs, dando vida a uma rede de formação continuada docente para que se propicie ao aprendente, ser o agente principal responsável pela aquisição do conhecimento, se comprometendo com seu próprio aprendizado utilizando-se das metodologias ativas de aprendizagem, promovendo uma transformação social por meio de uma prática conscientizadora e crítica.

O processo de educar, devido a múltiplos fatores, como a rapidez na produção de conhecimento, pela facilidade de acesso de informação, deixou de ser baseado apenas na transmissão de conhecimentos entre professor-aluno. $\mathrm{O}$ empoderamento gerado a partir de indivíduos que contemplam uma sociedade da informação, que cria, produz, lê, reflete e critica o conhecimento recebido, torna o educar, ensinar e aprender algo tão ágil quanto à fala.

Neste contexto, problematizar em sala de aula, seja ela física ou virtual, não se restringe a apenas apresentar questões, ultrapassando estas até chegar à discussão dos conflitos que fazem parte e mantém o problema apresentado; mas deve ser produzido ao final do tema, a fusão do conhecimento com a prática, criando vínculos a partir de sinapses baseadas nas experiências e vivências provocadas pelo educador ao seu aprendente. 
Neste ponto, deve ser utilizado todo artefato ao alcance para despertar o gosto, a curiosidade e a criatividade que, aliados a ferramentas computacionais, darão forma ao ambiente educacional, aonde um misto de ensinar e aprender que traz consigo a vontade de revisitar e continuar a descobrir, saber, reter e praticar mais e mais, formando um ciclo com loop infinito... porque aprender e ensinar tem de ser divertido, produtivo, criativo e emocionante!

Fica o convite a ler mais e buscar inspiração com as experiências relatadas neste livro, baseadas em vivências práticas com uso de $\mathrm{EaD}$, TICs interdisciplinaridade, jogos digitais e inteligência artificial.

Boa leitura!

\section{Maria Elaine dos Santos Léon}

Mestre em Geomática pela Universidade Federal de Santa Maria 
O ASSISTENTE A DOCÊNCIA DOS POLOS

DA UNIVERSIDADE ABERTA DO BRASIL:

UM ATOR PARA POTENCIALIZAR O ENSINO HÍBRIDO

Mylani Nathalini Dantas Costa

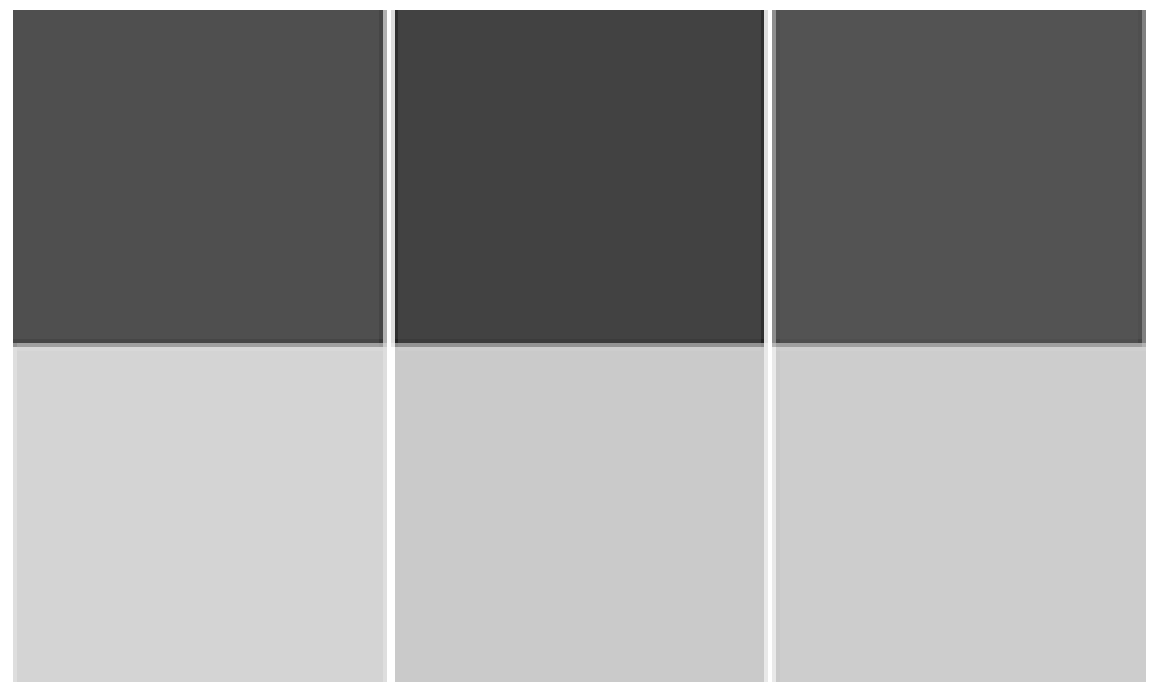




\section{INTRODUÇÃO}

A educação a distância vem crescendo bastante no Brasil e após a grande expansão que houve desta modalidade de ensino em meados de 2006, este sistema educacional teve que se adaptar as diferenças da $\mathrm{EaD}$ para o ensino presencial, de forma que algumas instituições continuaram a utilizar alguns modelos do ensino tradicional nesta nova modalidade, readaptando-se por exemplo ao ensino semipresencial.

Contudo, no decorrer de alguns avanços houve uma reestruturação curricular na EaD, enfatizando-a como totalmente a distância, exigindo do aluno a presença obrigatória no polo somente para realizar as provas presenciais e o estágio. Nesta perspectiva, diante das referidas mudanças e apesar dos cursos nas instituições públicas de ensino, em sua maioria ocorrerem totalmente a distância, percebe-se que as referidas medidas de certa forma, afastam o discente que tem interesse em aprimorar os conhecimentos da instituição. Neste contexto, a participação em atividades (presenciais) concomitantes ao curso contribuem para o ingresso de graduandos no meio acadêmico proporcionando uma nova visão quanto a formação e ao mercado de trabalho.

Desta forma, podemos englobar o ensino híbrido como um modelo no ensino o qual pode contribuir bastante para os cursos da EaD seja através da realização de eventos no polo de apoio presencial, projetos de pesquisa e extensão e outras atividades que contribuam para formação do referido profissional. Sendo assim, percebe-se que há a necessidade em elaborar, além de aplicar atividades no polo de apoio presencial possibilitando iniciação a pesquisa e a docência desses alunos.

O ensino híbrido no Brasil apesar de sua expansão em variados níveis de ensino ainda é visto como um termo novo mas que já possui aceitabilidade em sua aplicação. Neste contexto, para que possamos exemplificar metodologicamente a execução do blended learning mais conhecido no Brasil como ensino híbrido em um curso de física vimos que:

O discente primeiramente se prepara no AVA juntamente com a professora A para as atividades em sala, pratica os conceitos aprendidos com a professora B e depois revisa no AVA o conteúdo e estende seu aprendizado, o 
que os torna atores protagonistas, pois precisam dominar, alinhar, relacionar todos os conteúdos, para que consigam avançar durante a disciplina. A professora B então, conduz o encontro presencial com metodologias ativas colocando o discente como centro e a partir de um trabalho em equipe professores e discentes tornam-se parceiros nas atividades e corresponsáveis pelo processo (RIBEIRO; ANSELMO; JOHN, 2018, p. 7).

A referência acima nos mostra que no ensino híbrido há uma autonomia do aluno tanto no ambiente virtual quanto nos encontros presenciais. E após o discente exercitar virtualmente a aprendizagem com os profissionais do AVA, a referida troca torna-se mais prazerosa através da vivência e propagação dos conhecimentos por meio das experiências práticas sejam com os tutores presenciais, colegas do curso, além da comunidade externa realizadas no polo de apoio presencial.

\section{CURSOS UAB E O ASSISTENTE À DOCÊNCIA}

A oferta de cursos UAB possibilitou um maior acesso a cursos de graduação principalmente em áreas mais distantes das universidades públicas geograficamente. Nesta perspectiva, em meados de 2006 quando ocorreu uma grande expansão no acesso a cursos da $\mathrm{EaD}$. Os cursos ofertados ocorriam na modalidade semipresencial, ou seja, os alunos tinham encontros presenciais (semanalmente) não só durante a aplicação de provas. Mas com o passar do tempo, esta realidade mudou e os encontros presenciais passaram a serem obrigatórios somente nas provas (mensal a cada fim de módulo) como ocorrem até os dias atuais.

As mudanças tiveram pontos favoráveis e também desfavoráveis, como por exemplo, a necessidade de ter uma vivência maior no polo presencial envolvendo os conteúdos específicos e momentos que incentivem a iniciação à docência especificamente nos cursos de licenciatura. "A participação da educação a distância em 2006 era de 4,2\% do total de matrículas em cursos de graduação e aumentou sua participação em 2016 para 18,6\%". Censo de Educação Superior (2006, p. 7).

A ampliação da Educação a Distância se deu, principalmente, a partir da inclusão de cursos de graduação por intermédio da Universidade Aberta do Brasil - UAB os quais preocupam-se com o suporte 
de apoio presencial. Para que a estrutura de apoio presencial seja eficaz no atendimento aos alunos são necessários vários profissionais. A evasão é um fator que preocupa bastante o sistema da $\mathrm{EaD}$ no Brasil. Visando a diminuição a Capes incluiu em seu quadro de profissionais o "Assistente à Docência" para desempenhar determinadas atividades pedagógicas como Ator direto pelo funcionamento das atividades acadêmicas nos polos de apoio presencial na educação a distância.

Pode-se afirmar que a função de apoio e suporte pedagógico em um polo de apoio presencial apresenta alguns desafios. Sendo assim, sabe-se da necessidade de contribuir para diminuição do índice de evasão escolar na $\mathrm{EaD}$ o que, de imediato, remete a adoção de estratégias pedagógicas como o estímulo a interação, a motivação, o estímulo a persistência, o apoio e a assistência ao alunado para que o mesmo não se sinta sozinho apesar de cursar uma modalidade a distância. Segundo (BITTENCOURT, Ibsen; MERCADO, Luis , 2014 P 471):

[...] percebe-se que o grande problema dos alunos que estudam a distância está justamente nos primeiros anos ou semestres dos cursos, por isso a importância e o cuidado com o aluno na $\mathrm{EaD}$. O aluno muitas vezes se sente solitário, e com falta de estímulo para uma caminhada autônoma.

A partir destas concepções sabe-se da necessidade em utilizar a interação com intuito de acompanhar este aluno individualmente e/ ou coletivamente para que o mesmo não desista diante do primeiro obstáculo. Segundo Demarco e Honorato (p. 212), "dessa maneira é privilegiada a mediação pedagógica com destaque na interação e na relação entre os participantes do processo".

Pode-se afirmar que é na modalidade a distância que o discente testa todos os seus limites. São desafios como esses que permitem $o$ assistente à docência contribuir para permanência do alunado e para a conclusão de um curso superior com qualidade.

\subsection{Relato de experiência}

A partir das funções previstas em edital, elaborei um plano de trabalho especificando inicialmente as seguintes pretensões: aplicar e supervisionar as atividades que competiam ao cargo no polo de 
apoio presencial, além de divulgar prazos e o cumprimento das atividades obrigatórias por parte dos alunos. Outra ação relevante, seria a realização do atendimento aos discentes esclarecendo dúvidas relacionadas ao curso e/ou ambiente virtual de aprendizagem.

Além das demandas citadas, dentre as pretensões como Assistente à Docência vale ressaltar o acompanhamento frequente dos alunos fazendo um levantamento para que a partir das dúvidas mais persistentes pudéssemos realizar reuniões ou atividades de intervenção, sem esquecer do contato com estudantes ausentes no curso e das visitas domiciliares quando necessário através da análise de cada caso. Lembrando que esse trabalho foi pensado para ser realizado também através do contato direto com os tutores presenciais e o coordenador do polo. Veremos as atribuições postas no edital n. ${ }^{\circ}$ 01/2017- IPES (retificado em 01/11/2017) as quais mostravam as seguintes atividades que deveriam serem realizadas:

a) Trabalhar de forma articulada e colaborativa com o coordenador do polo, na organização de toda a estrutura de atendimento da tutoria presencial; na definição de horários e escalas das sessões de uso dos espaços; na coordenação; na aplicação das avaliações presenciais e em seu posterior acompanhamento;

b) Apoiar as ações gerenciais da CAPES;

c) Apropriar-se dos procedimentos acadêmicos das IPES que atuam no polo com o objetivo de apoiá-los em sua implementação;

d) Participar e apoiar projetos de ensino, pesquisa e extensão desenvolvidos pelas IPES que atuam no polo;

e) Interagir com alunos, coordenadores de curso, professores e tutores dos cursos do polo, visando a um trabalho acadêmico cooperativo;

f) Contribuir para o atendimento do calendário e do cronograma das disciplinas dos cursos em cada período letivo;

g) Fomentar e favorecer a formação de grupos de estudos entre alunos e tutores;

h)Encaminhar à CAPES relatórios de acordo com as definições da DED/CAPES;

i) Auxiliar as IPES na dinâmica do processo de atendimento tutorial, no uso contínuo uso das TIC em EaD e das ferramentas do Ambiente Virtual de Aprendizagem - AVA e nos encontros presenciais; 
j) Esclarecer dúvidas acadêmicas dos alunos, assegurando o atendimento aos estudantes, otimizando os encontros pedagógicos, entre outras atividades;

k) Auxiliar as IPES na articulação dos segmentos e na oferta dos cursos no polo;

1) Participar de capacitações promovidas pela CAPES e pelas IPES que atuam no polo;

m) Acompanhar o desempenho da tutoria dos cursos no polo, tendo em vista seu aperfeiçoamento;

n) Articular-se com os alunos, particularmente com aqueles que frequentam pouco o polo, informando-os sobre as ações realizadas no polo, buscando identificar e registrar suas dificuldades e os motivos da infrequência ao polo, visando evitar a evasão;

o) Estar presente nos encontros e nas avaliações presenciais em articulação com o coordenador do polo.

\subsection{Ações e resultados}

A primeira capacitação para exerção do cargo foi realizada por intermédio da Universidade Federal do Rio Grande do Norte UFRN. A partir disso, realizamos uma reunião com a equipe do UaB Polo Educa Grossos - UabPEG em que foi feita uma apresentação com o coordenador do polo aos tutores e toda equipe a respeito do cargo de Assistente à Docência e as referidas funções determinadas pela Coordenação de Nível Superior - CAPES para que pudéssemos fazer um levantamento sobre futuras ações a serem realizadas, visando aproximar os discentes dos cursos $\mathrm{EaD}$ ao polo para amenização da evasão, por intermédio das atividades de ensino, que seriam ofertadas aos alunos das instituições. Lembrando que as atividades realizadas e descritas abaixo, ocorreram apenas no período de 5 meses durante a execução do cargo.

Após os referidos momentos, como Assistente à Docência planejei com a coordenação do polo a realização de uma aula inaugural semestral, que até então, era realizada apenas quando os alunos ingressavam no curso. Nesta perspectiva, pensamos em dois momentos para o evento. O primeiro ofertou-se uma palestra com um pales- 
trante da Universidade Federal Rural do Semi Árido - UFERSA aos alunos sobre "A administração do tempo de estudo na EaD" visto que este tema era um desafio bastante notório para os discentes. O evento ocorreu sobre a presença de todos os coordenadores dos cursos das instituições públicas de ensino, coordenação de polo, Assistente à Docência e representantes mantenedores do município.

Em um segundo momento, os tutores se reuniriam com os graduandos e os coordenadores dos cursos da UFERSA/ UERN e repassaram informações semestrais, proporcionando um momento de dúvidas dos alunos com a coordenação, informes a respeito do AVA e divulgaram próximos eventos que ocorreriam no UaBPEG, .O evento ocorreu de forma esclarecedora e os alunos puderam aproveitá-lo como hora extra curricular na grade do curso (algo que foi pensado durante o planejamento).

Outra atividade que contou com a organização de toda equipe do polo foi a apresentação do Laboratório de Matemática do UaBPEG para os professores de Grossos- RN conhecerem os materiais concretos possibilitando o uso da comunidade externa em aulas do ensino básico de matemática. Além da equipe do polo o evento contou com a participação de alunos da graduação e tutores como organizadores do evento, gerando assim mais uma certificação. Foi um evento bastante proveitoso e que após o mesmo, vários professores do ensino básico, estão trazendo seus alunos para participarem de aulas utilizando os materiais do laboratório de matemática.

O acompanhamento sobre a situação dos alunos nos cursos também é realizada pelo Assistente à Docência, que mantém um contato direto com os tutores no acompanhamento também sobre o acesso dos discentes ao AVA.

Vale ressaltar, que atividades de extensão contribuem bastante para a amenização no índice de evasão dos alunos. Dentro desta perspectiva, através da troca de ideias com a equipe do polo foi elaborado pelo Assistente à Docência um projeto de extensão o qual havia sido pensado pela coordenação do polo mas que até então, teoricamente não tinha sido colocado em prática.

Neste contexto, o assistente à docência realizou a escrita do projeto "Preparatório Proen IFRN do UaBPEG" objetivando capacitar alunos do $9^{\circ}$ ano de Grossos - RN nos conteúdos de português 
e matemática do referido processo seletivo visando ingresso no nível médio integrado, possibilitando a participação dos alunos das graduações ministrarem aulas de reforço escolar. Sem esquecer que na etapa inicial do projeto de extensão será feita uma capacitação aos alunos da graduação visando prepará-los para iniciação à docência. No decorrer das atividades, analisaremos o desempenho dos alunos do $9^{\circ}$ ano na prova do Proen/IFRN para propor melhorias no projeto além das contribuições que o mesmo proporcionará aos graduandos quanto a iniciação à docência. Após orientações e análise, a UFRN aprovou o projeto o qual está aguardando alguns trâmites para seu início.

A presença do Assistente à Docência nas atividades do polo como reuniões, provas e encontros presenciais de todas as instituições que ofertam cursos é dever e de grande importância. Neste contexto, as ações continuam como por exemplo, através da elaboração de uma semana universitária, em que almejamos a participação de todos os alunos levando em consideração que será um evento o qual tratará de temas específicos relacionados aos cursos de graduação.

Diante das experiências no referido cargo até o momento, pode-se afirmar que o Assistente à Docência tem muitas atribuições pedagógicas a serem cumpridas. Neste contexto, é um profissional que deve estar presente em todas as ações do polo de apoio presencial, intervindo de forma positiva e participativa com toda equipe de profissionais atuantes nos cursos. Esta atuação tem bastante relação com a educação híbrida, a qual permite ao aluno atividades a distância e também presenciais no polo. Pois os conhecimentos e trocas de experiências que o aluno executará no AVA serão aplicados e aprimorados também por intermédio das ações que o polo de apoio presencial deve proporcionar.

\section{CONSIDERAÇÕES FINAIS}

Percebe-se que o ensino híbrido é um modelo de grande importância para $\mathrm{EaD}$ diante de todos os avanços e desafios ocasionados nesta modalidade de ensino. A atuação do Assistente à Docência surgiu da necessidade em contribuir de forma pedagógica para amenização do deficit de evasão e tem bastante ligação com este método de ensino diante das ações já realizadas. 
Desta forma, apesar desta nova função atuar a pouco tempo, é possível considerar que a junção da mesma com o modelo ensino híbrido nos polos $\mathrm{UaB}$ contribuem bastante para obtenção de resultados relevantes. Os mesmos relacionam-se com intervenções visando cumprir atividades no decorrer do curso e tenham como resultado a assistência, participação, estímulo a interação e a permanência dos alunos durante toda graduação.

\section{REFERÊNCIAS}

CENSO DE EDUCAÇÃO SUPERIOR. Portal Inep, 2016. Disponível em : http://portal.inep.gov.br/artigo/-/asset_publisher/B4AQV9zFY7Bv/content/mec-e-inep-divulgam-dados-do-censo-da-educacao-superior-2016/21206. Acesso em: 23 maio 2019.

EDITAL DE SELEÇÃO DE ASSISTENTE À DOCÊNCIA. n. 001/2017IPES (retificado em 01.11.2017). Disponível em: http://177.20.146.36/ index.php/editais-e-concursos/item/ipes-lanca-edital-de-selecao-de-assistente-a-docencia. Acesso em: 23 maio 2019.

RIBEIRO, Karen Santos Batista; ANSELMO, Dayse Nascimento; JOHN, Olivia Ortiz. Um estudo de caso da disciplina física termodinâmica ondas o óptica aplicada no modelo de ensino híbrido. Belo Horizonte - MG. Maio de 2018. Disponível em: http://www.abed.org.br/congresso2018/anais/trabalhos/7850.pdf . Acesso em: 20 maio 2019.

VIEIRA, Márcia de Freitas. A gestão de EaD no contexto dos polos de apoio presencial: proximidades e diferenças entre e universidade aberta ao Brasil a as instituições universitárias privadas. Doutoramento em educação na área de especialização em educação a distância e elearning (EdeL). Universidade aberta, 2018. Disponível em: https://repositorioaberto.uab.pt/bitstream/10400.2/7182/1/td_marciavieira.pdf. Acesso em: 22 maio 2019. 


\section{BLENDED LEARNING NA EDUCAÇÃO SUPERIOR: UMA EXPERIÊNCIA DE ENGAJAMENTO DOS ALUNOS DO CURSO DE CIÊNCIA DA COMPUTAÇÃO}

Danniel Cavalcante Lopes Kátia Cilene da Silva

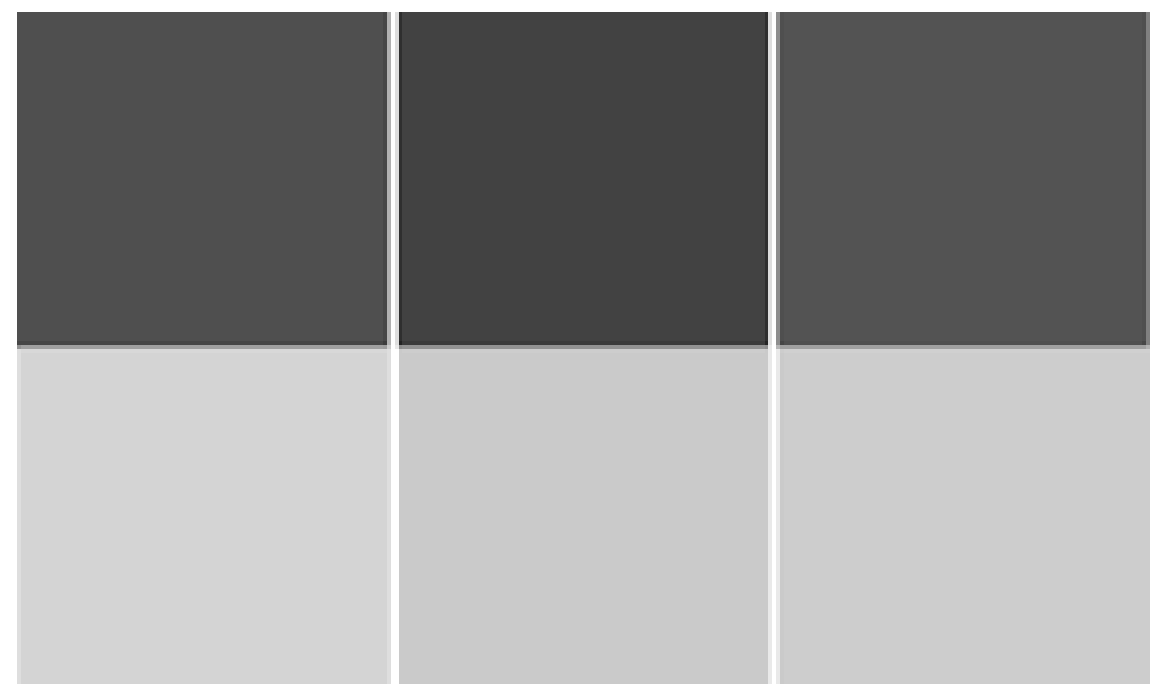




\section{INTRODUÇÃO}

No ambiente universitário, não basta que o conhecimento esteja ao alcance dos alunos, mas também é preciso utilizar métodos que permitam a construção contínua dos conhecimentos teóricos e práticos necessários à formação desses alunos. Deve-se considerar que esta construção está diretamente relacionada à qualidade nos processos de ensino e aprendizagem que, por sua vez, é influenciada por fatores relacionados ao docente, ao aluno e às condições de ensino disponibilizadas pelas instituições.

No caso das Ciências da Computação, esta área está cada vez mais abrangendo novas áreas do conhecimento e atribuindo grande valor à informação, aumentando a produção desta em grande escala, no último século. Com isso, os cursos de graduação na área de Computação e Informática estão ocupando mais espaço no Ensino Superior. Por se tratar de um curso na área de exatas, muitas vezes os conteúdos técnicos são priorizados em detrimento dos aspectos didáticos e pedagógicos.

Dado o alto índice histórico de reprovação nas disciplinas dos cursos de computação e a consequente retenção dos alunos no curso, surge a necessidade de adoção de novas estratégias de engajamento dos alunos, para além das estratégias motivacionais. Surge, assim, a preocupação com a necessidade de que o aluno tenha interesse em agregar conhecimento através das atividades desenvolvidas pela universidade e/ou curso e que seja estimulado pelo professor a obter uma formação multidisciplinar. Conforme Demo (2000, p.11), é fundamental ter-se em mente que "[...] a educação representa o principal investimento na oportunidade de desenvolvimento humano sustentado."

Para responder a essas duas necessidades, tanto de engajamento dos alunos, quanto de promover a formação multidisciplinar tão requerida no mercado de trabalho atual, o professor deve ser capaz de proporcionar ao aluno "desenvolver seus esquemas mentais, suas próprias estruturas conceptuais no que se refere à aquisição de conhecimentos e à solução de problemas mais complexos" (UFRGS, 1974, p. 45).

Neste contexto, diversos recursos de uma abordagem de ensino híbrido foram adotados em busca do maior engajamento dos alunos 
da disciplina Computação e Sociedade, do curso de bacharelado em Ciência da Computação e uma universidade federal do semiárido nordestino, a Universidade Federal Rural do Semi-Árido (UFERSA).

\section{CONTEXTO DE APLICAÇÃO}

O curso de Ciências da Computação da UFERSA foi autorizado em 2006 e reconhecido em 2012, ou seja, é um curso que chega aos seus 13 anos de existência. Nos últimos três Exames Nacionais de Desempenho Estudantil (ENADEs), obteve-se nota 4, segundo os critérios de classificação Ministério de Educação/Instituto Nacional de Estudos e Pesquisas Anísio Teixeira (MEC/INEP). Apesar dos resultados positivos, a quantidade de alunos formandos diminuía a cada semestre, pois, com exceção da primeira turma, todos os semestres seguintes, não se formavam mais que 10 alunos, considerando os regulares e irregulares.

Ao longo dos anos, em pesquisas realizadas pelos coordenadores, percebeu-se que a evasão era baixa, mas a retenção elevada. Com entrada semestral de 25 discentes e 9 semestres de duração, a quantidade de discentes com matrícula ativa estava em torno de 200 alunos todos os semestres, portanto $12 \%$ de vagas ociosas, aproximadamente. Considerando uma média de 5 discentes formados por semestre, o índice de sucesso era de, aproximadamente, $20 \%$.

Percebeu-se que a matriz curricular do curso estava desatualizada e alguns componentes curriculares tinham um elevado índice de retenção, o que desestimulava tanto os discentes, quanto os docentes, pela falta de interesse e empenho dos alunos durante o curso.

Em sua primeira versão, que ocorreu até 2017.2, o curso era no turno noturno, por acreditar-se que a maioria dos discentes trabalhavam. Porém, em pesquisas realizadas com os discentes, percebeu-se que, mesmo sendo um curso noturno, a maioria dos discentes não trabalhavam.

O Núcleo Docente Estruturante (NDE), em reunião com os professores, propôs, sendo deliberado positivamente pelo colegiado, a mudança do turno para integral e a entrada anual de 50 discentes. Com essa atitude, desejava-se mudar o perfil do discente e buscar o 
estudante profissional, que viva a universidade diariamente e, consequentemente, tenha um maior engajamento com o curso.

O novo Projeto Pedagógico do Curso (PPC), que está em execução desde 2018.1 foi baseado nas novas diretrizes curriculares dos Cursos de Computação no Brasil. Nesse novo PPC foram inseridas atividades complementares que não existiam antes, com o intuito do discente procurar informação e aprendizado extraclasse. A nova grade ficou mais flexível e mais voltada para a computação em si, podendo o discente seguir algumas linhas de formação.

Com a mudança da grade curricular, foi inserida uma nova disciplina denominada: Computação e Sociedade, pois ao longo dos 12 anos de existência do curso, percebia-se que alguns discentes ainda entravam no curso sem compreender qual seria sua atuação no mercado e sua contribuição para a sociedade, enquanto profissional da área de computação.

\section{REFERENCIAL TEÓRICO}

Com a publicação da Portaria no 4.059 , de 10 de dezembro de 2004, do MEC, a qual autorizou as Instituições de Ensino Superior (IES) incluírem, na organização pedagógica e curricular de cursos em nível superior reconhecidos, atividades semipresenciais que não ultrapassem vinte por cento da carga horária total do curso, tem crescido consideravelmente o número de universidades, públicas e privadas, que oferecem o blended learning. Quando são combinadas múltiplas abordagens de aprendizagem em prol de uma formação mista, conjugando momentos a distância e presenciais, como ambiente de aprendizagem, fica caracterizado o $B$-learning, que é a abreviatura de blended learning.

Niskier (1999) e Roca (2001) afirmam que considerando a relação dos momentos presenciais com o uso da tecnologia computacional para propiciar momentos a distância, pode-se classificar o modelo de ensino como blended learning.

O blended learning configura-se como um processo equilibrado de utilização da aprendizagem presencial (mediatizada ou não) e online, combinando as potencialidades de ambas, como apresentados 
em Voos (2003). O ensino híbrido, ou blended learning, é uma das tendências novas tendências da Educação, que promove uma integração entre o ensino presencial e online visando à personalização do ensino.

A educação híbrida traz a concepção de que as aulas sejam mais ativas, acessíveis e flexíveis, permitindo que o aluno tenha mais liberdade em seu aprendizado. A integração de conteúdo online no ambiente virtual de aprendizagem e o conteúdo presencial são os diferenciais que auxiliam o aprendizado dos estudantes e potencializam o seu engajamento no curso.

$\mathrm{O}$ acesso e uso as tecnologias de informação (TICs) é um fator importante para implantação do ensino híbrido, de forma que haja uma interação entre o ambiente virtual de aprendizagem e as aulas presenciais, como proposto por Valente (2011), que afirma que os aspectos fundamentais da implantação da sala de aula invertida são a produção de material para o aluno trabalhar on-line e o planejamento das atividades a serem realizadas na sala de aula presencial. Tais orientações foram seguidas no planejamento da disciplina de Computação e Sociedade usando metodologias híbridas.

\section{RELATO DE EXPERIÊNCIA}

A disciplina Computação e Sociedade foi pensada de maneira multidisciplinar/interdisciplinar desde o primeiro dia de aula, pois a ideia foi mostrar como a computação está inserida nas diversas áreas da sociedade. Em 60 horas (4 créditos), o discente tem contato com assuntos como: a) a evolução da sociedade e a sociedade da informação; b) o profissional da computação; c) o ensino a distância e as possibilidades de atuação na área; d) software livre; e) TI verde; f) jogos educacionais; g) empreendedorismo e startups; h) indústria 4.0; i) introdução a robótica; j) aplicações da computação na saúde, na engenharia, na agronomia, na economia, na educação, no transporte público, na comunicação, na indústria; e, k) outras tendências tecnológicas. Transversalmente aos temas trabalhados na disciplina são abordados aspectos como ética profissional, cidadania, trabalho em grupo, criatividade, autonomia/proatividade e espírito empreendedor. 
$\mathrm{Na}$ matriz curricular anterior, percebeu-se que muitos dos discentes eram reprovados por faltas, ou seja, desistiram da disciplina antes mesmo de terminar o semestre. Sendo Computação e Sociedade uma disciplina introdutória, na qual deseja-se apresentar as tendências tecnológicas e de mercado na área de computação, para estimular a participação e a pesquisa dos discentes, foram pensadas atividades para todas as aulas.

Com o objetivo de fidelizar o aluno à disciplina, optou-se por uma avaliação continuada e formativa, abrindo mão da prova tradicional, e adotando uma proposta de avaliação realizada ao longo do semestre, composta por atividades presenciais e online, participação nas aulas e desenvolvimento de pesquisa, sistematização/apresentação dos resultados de pesquisa e redação de texto científico.

\subsection{Ações desenvolvidas}

Durante a realização da disciplina foram disponibilizadas videoaulas, atividades online, orientações online e um MOOC, para além das atividades presenciais realizadas em sala de aula.

Como atividades online foi solicitada a redação de textos em quatro oportunidades: a) uma Resenha sobre o texto "O impacto da tecnologia de dados na sociedade do futuro"; b) um relato da percepção dos alunos sobre os cursos online; c) a opinião dos alunos sobre a regulamentação da profissão de informática no Brasil; e, d) uma análise do filme "Revolution OS" sobre a criação do Linux.

Também foram disponibilizadas três vídeo aulas: a) sobre o "Histórico da EaD"; b) sobre as "Ferramentas, funções e profissionais envolvidos"; e, c) sobre as "Possibilidades de atuação profissional na EaD”.

No que se refere ao uso de ambientes virtuais de aprendizagem, o Sistema Integrado de Gestão Acadêmica (SIGA) foi utilizado durante toda a disciplina, bem como foi apresentado aos alunos o Open redu, ambiente virtual de aprendizagem em nuvem.

Foi solicitado que cursassem um Massive Online Open Course (MOOC), sobre a Indústria 4.0, para que quando a aula presencial sobre o assunto fosse realizada os alunos pudessem interagir mais e colaborar durante o desenvolvimento dos conteúdos. 
Para estimular o aspecto empreendedor, foi solicitado aos alunos que descrevessem as categorias de startups, elencassem um segmento de atuação e desenvolvessem uma proposta de criação de uma startup de produtos/serviços de computação.

O estímulo à interação, construção colaborativa e trabalho em equipe foi estimulado através da proposição de seminários sobre temas emergentes na sociedade contemporânea: segurança de dados, informática na saúde, realidade virtual e aumentada, informática na educação, computação quântica, transporte compartilhado/autônomo, inclusão digital/acessibilidade, robótica, STEM, automação residencial, economia/criptomoedas e comércio digital. Por fim, foi proposta uma visita técnica ao Porto Digital, em Recife - PE, para que os alunos pudessem ver in loco a aplicação profissional dos conhecimentos da sua área de formação.

\subsection{Percepções dos alunos}

No primeiro semestre de oferta da disciplina, ao final do semestre, foi aplicado um questionário, para o discente que desejasse comentar a experiência na disciplina. Dez discentes preenchem o questionário de forma espontânea.

Um dos alunos cita a diversidade de materiais e mídias utilizados como um diferencial, como segue:

$<$ ALUNO 1> Achei a disciplina bastante interessante e apresentou o conteúdo de forma bem descontraída e clara, com toda certeza posso afirmar que todas as expectativas foram alcançadas, porém, sempre há espaço para melhorar. Sobre os pontos positivos, gostei dos métodos de avaliações e as metodologias de ensino que o professor apresentou, uso de vídeos, programas e plataformas para melhorar o nosso processo de aprendizagem e o acesso à informação.

Já outro aluno destaca o aspecto de humanização dos conteúdos técnicos apresentados, a saber:

$<$ ALUNO 2> A disciplina foi muito proveitosa e possui um teor diferenciado na formação humanística do profissional das áreas exatas/tecnológicas. Adorei a maneira como ela serviu de matéria introdutória ao campo 
da computação. Achei particularmente interessante o fato de explorarmos questões como software livre e o posicionamento acerca da regulamentação da profissão; senti falta de mais discussões que girassem em torno da ética na profissão. A maneira como os textos e as tarefas foram distribuídos me soaram bem espaçados e eu gostei da abordagem voltada para leituras e interpretação de temas.

O aspecto da construção colaborativa e do trabalho em equipe, bem como proposta de avaliação continuada foram citados por um dos alunos como um diferencial da disciplina, como segue:

$<$ ALUNO 3> Gostei muito da disciplina. Se a intenção era dar uma visão panorâmica do uso da computação na sociedade, mostrando sua contribuição das diversas áreas que iremos estudar e suas aplicações no ambiente onde vivemos, então atingiu o objetivo. A metodologia de ensino adotada foi outro diferencial pois mostrou aos alunos a necessidade do trabalho em grupo para um aprendizado compartilhado. As aulas práticas como a dos robôs Lego foram muito divertidas. Por fim, o método de avaliação contínua foi outro diferencial.

O aspecto motivacional do engajamento com o curso também foi citado por outro aluno:

$<$ ALUNO 4>A melhor disciplina até agora!!!! A disciplina foi muito importante, principalmente para leigos na computação

Também a metodologia adotada foi citada como ponto positivo para a oferta da disciplina com uma abordagem híbrida, como citado:

$<$ ALUNO 5> Achei o modelo de aula dado pelo professor muito legal e diferente, o que não deixa de ser instrutivo também, uma troca de ideias durante as aulas muitas vezes se torna bem mais instrutiva do que as aulas mais ortodoxas onde um professor fala e aluno ouve, na minha opinião só teve pontos positivos no que diz respeito a disciplina. Em resumo, ótima disciplina. Obrigado!

Outro aluno também destaca a importância e a eficácia da abordagem de avaliação continuada, a saber: 
<ALUNO 6> Achei uma ótima disciplina de início de curso, aborda bem as características da computação no contexto social... Dos vários pontos positivos, cito um que mais se destaca, o fato de não ter provas, acho o meio de avaliação usado em sua disciplina mais eficaz do que fazer provas objetivas.

O último destaque é dado pela fala de um aluno que ressalta a importância de se trabalhar a redação científica, como segue:

$<$ ALUNO 7> Foi uma ótima disciplina, que conseguiu mostrar os caminhos que um formado em ciência da computação conseguiria ir e deu oportunidades de extensão para alunos que se interessaram, os pontos mais positivos foram as atividades feitas em sala que fizeram treinar a escrita, pois muitas pessoas ainda não tinham feito um artigo sequer na vida, ou até mesmo um relatório.

$\mathrm{Na}$ segunda oferta da disciplina foi solicitado, na primeira semana de aula, que os discentes respondessem qual sua expectativa em relação a disciplina, sendo que dezesseis discentes responderam ao questionário e cujos resultados são apresentados no quadro 1.

Quadro 1- Expectativas dos alunos em relação à disciplina

Uma disciplina dinâmica.

Aprender com os feitos já realizados pela tecnologia para influência em um futuro melhor para a humanidade. Para transformar a computação em algo bom para a sociedade.

Saber um pouco mais como age o ramo da computação na sociedade.

Ter uma visão mais ampla do potencial da computação como meio de transformação social e como todos as mudanças tecnológicas influenciam o cotidiano das pessoas.

Minha expectativa é o conhecimento teórico, talvez o prático, e a computação aplicada a sociedade, com inclusão etc...

Gostaria que soubesse um pouco mais sobre a maravilha que e a computação além do mais, como ela é interagida com a sociedade hoje em dia.

Compreender melhor as possibilidades que o curso proporciona, assim como o papel do mesmo na nossa sociedade

O que eu espero da disciplina é refletir dentro dela acerca dos impactos da computação e seus avanços na nossa sociedade em todos os âmbitos, seja no mercado, na medicina, no psicológico, na criação de sentido e tudo que gira em torno de nós... 
Acho que a disciplina falará da sociedade e de como os computadores em conjunto da informática influenciam e interagem com ela.

Aprender mais sobre a importância da área da Ciência da computação na sociedade, com suas aplicações e finalidades.

Uma forma de melhor valorizarmos e área com vários pontos de vista relacionados a ela.

Acredito que a disciplina vá nos introduzir a situação do sistema da informação (computação, internet, etc..) na sociedade, do princípio até a atualidade, e talvez oque achamos que poderá ocorrer futuramente.

Espero que a disciplina mostre os laços que a computação tem com a sociedade, não se baseando apenas em cálculos, mas também em aulas teóricas.

Tal disciplina de extrema importância na vida acadêmica de nós, os alunos, na qual precisamos da base ofertada por essa matéria pra seguir.

Aparentemente uma disciplina voltada para as áreas de humanas, sendo de extrema importância. E por sua vez, ter debates que engloba o curso ciência da computação no mercado de trabalho de maneira social. O uso da ética e senso comum espero que seja debatido em sala também.

Quero conhecer algumas das profissões em que posso atuar ao término do curso, já dando um foco maior na área acadêmica

Minha expectativa é de que possamos aprender e ver de um lado mais humano o objetivo de estarmos cursando ciência da computação, afinal como o professor disse na sala de aula a área da computação é uma disciplina de meio e não de fim.

Espero conseguir manter o foco ate o final e não reprovar em nenhuma matéria, aprendendo ao máximo e desenvolvendo uma boa lógica computacional

Fonte: Elaborado pelos autores (2019)

\section{DISCUSSÃO DOS RESULTADOS}

No momento a disciplina está em sua segunda oferta. Dos cinquenta discentes matriculados na primeira oferta da disciplina apenas um foi reprovado por frequência, um foi reprovado por nota $e$ dois trancaram o curso, o que configura $92 \%$ de índice de conclusão. $\mathrm{Na}$ segunda oferta, um aluno trancou o curso e dois foram reprovados por frequência.

Alguns estudos correlatos foram encontrados como o de Neves et al. (2017), que apresenta um relato de experiência sobre o modelo proposto na implantação da modalidade semipresencial em cursos de graduação, assim como a pesquisa relatada por Amaral et al. (2018), que analisou o processo de implementação do ensino híbrido 
no ensino superior, considerando as metodologias e o fazer pedagógico de sete disciplinas curriculares distribuídas em três grandes áreas de conhecimento.

O relato de Neto e Coimbra (2018) apresenta uma proposta de currículo inovador, integrado e por competências para implementação de cursos de graduação no formato híbrido, muito próximo da proposta aqui apresentada para a disciplina Computação e Sociedade.

Já o estudo de Ribeiro et al. (2018) também parte do princípio que os profissionais no século XXI precisam desenvolver novas competências e habilidades, diferentes das possíveis de se desenvolver no modelo do ensino tradicional. Os resultados encontrados por Ribeiro et al. (2018) sobre o desempenho dos discentes na disciplina, bem como a percepção destes sobre a modalidade de ensino são similares aos encontrados até aqui, na oferta da disciplina Computação e Sociedade durante os dois últimos semestres.

\section{CONSIDERAÇÕES FINAIS}

O estudo de caso mostrou a viabilidade da adoção de abordagens híbridas como estratégia para o engajamento dos alunos do ensino presencial. Diversos pontos positivos foram citados pelos alunos que cursaram a disciplina, como promover maior interação entre eles na construção colaborativa dos conhecimentos durante a disciplina, no desenvolvimento de habilidades de trabalho em equipe, na possibilidade de percepção das diferentes áreas de atuação e possibilidades para o profissional de computação e no exercício de competências para redação científica.

Sugestões apresentadas pelos alunos na primeira oferta da disciplina como a falta de mais espaços envolvendo rodas de discussão e a necessidade de que o aluno desenvolva uma certa cultura de se organizar e ter foco fora da sala de aula, para realizar as atividades online foram implantadas na segunda oferta da disciplina.

Também foi possível perceber a motivação dos alunos em comparação com as demais disciplinas ofertadas de modo tradicional, cujo destaque foi dado pelos alunos à metodologia inovadora adota no desenvolvimento da disciplina. 


\section{REFERÊNCIAS}

AMARAL, R. C. B. M.; GOUVEA, A. P.; COSTA, R. C.; MELLO, S. R. O.; SOUZA, F. N.; MUHLBAUER, M.. Implantação do ensino híbrido em cursos de graduação nas faculdades São José: relato de experiências. Anais...24 $4^{\circ}$ Congresso Internacional ABED de Educação a Distância. Florianópolis: ABED, out 2018.

DEMO, P. Conhecer \& aprender: sabedoria dos limites e desafios. Porto Alegre: ArtMed, 2000.

NETO, S. P.; COIMBRA, J. C. P.. Metodologia para implementação de currículo integrado e por competências em cursos híbridos. Anais ... $24^{\circ}$ Congresso Internacional da ABED de Educação a Distância. Florianópolis: ABED, out. 2018.

NEVES, L. M.; HAAS, C. M.; TARCIA, R. M. L.; BULGO, F. C.. A modalidade semipresencial em um grupo educacional privado: uma proposta de ensino híbrido. Anais... $23^{\circ}$ Congresso Internacional da ABED de Educação a Distância. Foz do Iguaçu: ABED, set. 2017.

NISKIER, A. Educação à distância: a tecnologia da esperança. Políticas e estratégias para a implantação de um sistema nacional de educação aberta e à distância. São Paulo: Loyola, 1999.

RIBEIRO, K. S. B.; ANSELMO, D. N.; JOHN, O. O. Um estudo de caso da disciplina física termodinâmica, ondas e óptica aplicada no modelo de ensino híbrido. Anais... do $24^{\circ}$ Congresso Internacional da ABED de Educação a Distância. Florianópolis: ABED, out. 2018. ROCA, O. A autoformação e a formação a distância: As tecnologias da educação nos processos de aprendizagem. In: Juana Maria Sancho (Org). Para uma tecnologia educacional. Porto Alegre, RS: ArtMed, 2001, p.183-207.

VALENTE, J. A. Blended learning e as mudanças no ensino superior: a proposta da sala de aulainvertida. Educar em Revista. Edição Especial. Curitiba: Editora UFPR, n. 4, 2014. p. 79-97.

VOOS, Richard, "Blended-learning: What is it and where might it take us?" Perspectives in Quality Online Education. Sloan Consortium: 2003, volume 2, issue1- February, 3-5.

UFRGS / Faculdade de Educação / Laboratório de Ensino Superior. Planejamento e organização do ensino: um manual programado para o treinamento do professor universitário. Porto Alegre: Globo, 1974. 


\section{BLENDED LEARNING EM LICENCIATURAS DE ENSINO DE CIÊNCIAS E COMPUTAÇÃO}

Kátia Cilene Silva

Rosângela Gonçalves dos Santos

Ana Karine Das Chagas Vieira

Michela Melo da Silva

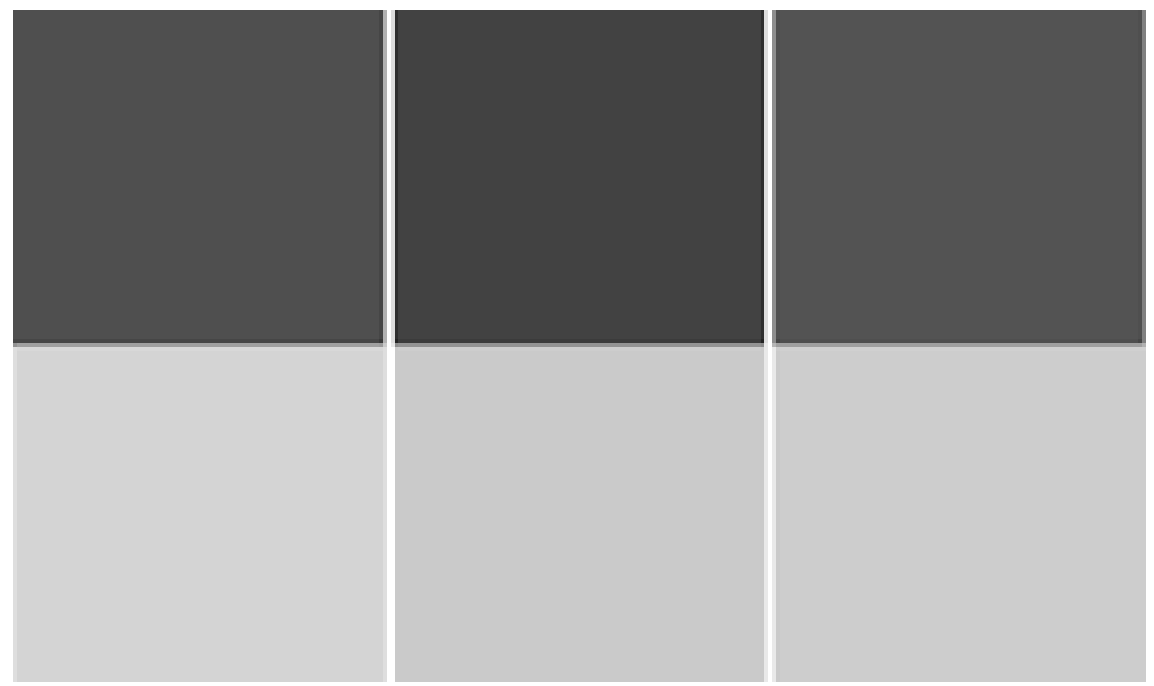




\section{INTRODUÇÃO}

Atualmente, os cursos à distância vem ganhando muito espaço nas universidades em função da política de expansão do acesso e permanência ao ensino superior, na qual a Universidade Aberta do Brasil (UAB) tem forte participação. A UAB se constitui como um sistema complexo que agrega e integra entidades governamentais em diferentes esferas administrativas, envolvendo tanto atores docentes quanto técnicos. Porém, apesar dos esforços realizados pelos atores nas mais diversas instâncias do sistema ainda existem diversos desafios para a gestão a serem superados e problemas nos processos a serem identificados e sanados para que os objetivos propostos em sua constituição sejam alcançados, principalmente no que se refere a um dos seus principais objetivos: a formação de professores da/para a Rede Pública de Educação Básica.

Neste sentido, a comunidade acadêmico/científica tem demandado esforços significativos no intuito de aperfeiçoar estruturas e práticas adotadas nos cursos a distância no país, com o objetivo de impulsionar o acesso ao Ensino Superior. Pode-se verificar os esforços das equipes multidisciplinares no auxílio à construção gradativa de conhecimento por parte dos alunos, potencializada pela mediação didático-pedagógica realizada pelos diversos atores docentes de um Ambiente Virtual de Aprendizagem (AVA). Esta realidade torna-se ainda mais perceptível nos cursos de formação de professores a distância que, além do desafio de formar profissionais a distância, agrega a este a necessidade de formar esses profissionais para o uso das tecnologias digitais em sala de aula.

Neste contexto, o presente artigo relata a experiência de oferta da disciplina de Introdução à Educação a Distância, concomitantemente, para 4 turmas das Licenciaturas em Computação, Física, Matemática e Química ofertadas na modalidade a distância, por uma universidade federal do semiárido potiguar, componente do Sistema $\mathrm{UAB}$, considerando o perfil dos alunos, as estratégias de ensino online adotadas, bem como as diferentes estratégias presenciais utilizadas como potencializadores e motivadoras, observando as respostas dos alunos a essas estratégias híbridas. 


\section{FUNDAMENTAÇÃO TEÓRICA}

Entre 2004 (ano anterior à criação da UAB) e 2018, a quantidade de instituições autorizadas pelo Ministério da Educação (MEC) a oferecer cursos Superiores na modalidade a distância cresceu de 10 para 577. A evolução do número de alunos foi ainda mais significativa, aumentando de 309.957 no primeiro ano do levantamento para mais de 1.300.000 em 2017, alta de 213,8\% (ABED, 2016). Já os dados atuais apresentados no CENSO EAD.BR (ABED, 2016, p. 7) indicam que: a) as instituições formadoras contam, em média, com 1.000-4.999 alunos; b) o número total de alunos contabilizado foi de 5.048.912, sendo 1.108.021 em cursos regulamentados totalmente a distância e semipresenciais e 3.940.891 em cursos livres corporativos ou não corporativos; c) o acréscimo no número de alunos de 2014 para 2015 foi de, aproximadamente, $29,95 \%$, e de mais $48 \%$ entre 2015 e 2016; e, d) a quantidade de instituições credenciadas para ofertar Educação a Distância $(\mathrm{EaD})$ cresceu mais de 65\%, nos últimos 10 anos.

Uma informação interessante é que $42 \%$ das instituições que ofertam EaD no Brasil encontram-se no sudeste e, destas, 22\% encontram-se localizadas em São Paulo (ABED, 2016, p. 7).

Além dos investimentos da iniciativa privada, algumas ações da política de expansão de oferta do ensino superior no Brasil também têm sido de fundamental importância para o estímulo da $\mathrm{EaD}$ no país, como o projeto da $\mathrm{UAB}$, que vem sendo implantado desde 2005 e tem o objetivo de interiorizar a oferta de cursos e programas de Educação Superior por meio da articulação com Instituições de Ensino Superior (IES) públicas já existentes.

Sobre preparação das IES para este novo contexto educacional, Franco (2013) afirma que

As Universidades brasileiras se preparam com a educação a distância em um cenário muito diferente, devido ao advento daquelas que foram chamadas 'Novas Tecnologias de Informação e Comunicação'. Esse novo cenário impõe uma constante modificação na vida das pessoas e, de maneira especial, trouxe mudanças significativas ao modo de fazer a educação a distância (p. 12). 
Este novo contexto em que a $\mathrm{EaD}$ se encontra requer dos professores em formação o desenvolvimento de novas competências; competências essas que irão fortalecê-los e capacitá-los a utilizar a $\mathrm{EaD}$ e as tecnologias digitais de forma a contribuir com o processo de ensino e aprendizagem, em vista de novos e crescentes desafios. Sobre essas novas competências, Behar et al. (2013) argumentam ser

[...] a reunião ou o conjunto de condições, recursos, elementos disponíveis aplicados em determinada situação. [...] as competências tem se ampliado para uma perspectiva além da educação profissional. Desta forma, entende-se que não são somente habilidades ou conhecimentos, mas uma combinação destes com as atitudes que irão compor as competências, indicando as várias possibilidades de sua contribuição na área educacional (BEHAR et al., 2013, p.21-22).

O desenvolvimento de tais competências tona-se ainda mais premente quando se percebe o perfil de alunos da educação básica, atualmente. De acordo com Neto e Franco (2010, p.14) a Geração " $\mathrm{Z}^{\text {"1 }}$, conhecida também como "geração silenciosa" tem característica de ser composta por crianças e adolescentes que vivem em um círculo de internet, telefone, vídeo e internet novamente.

Conhecendo esse perfil, os professores compreendem a importância da qualificação e já veem como necessidade o conhecimento e aplicação das tecnologias digitais, como afirma Rezende (2002):

$\mathrm{Na}$ virada do século, não se trata mais de nos perguntarmos se devemos ou não introduzir as novas tecnologias da informação e da Comunicação no processo educativo. [...]. Atualmente, professores de várias áreas reagem de maneira mais radical, reconhecendo que, se a educação e a escola não abrirem espaço para essas novas linguagens, elas poderão ter seus espaços definitivamente comprometidos (Rezende, 2002, p.1).

Neste sentido, já existem esforços da comunidade acadêmica objetivando subsidiar o professor com metodologias e ferramentas que potencializem o aprendizado, como o estudo apresentado por

\footnotetext{
${ }^{1}$ Geração Z, uma geração que nasceu sob o advento da internet e do boom tecnológico e, para eles, estas maravilhas da pós-modernidade não são nada estranhável. Em https://www. tecmundo.com.br/curiosidade/2391-o-que-e-a-geracao-z-.htm. Acesso em 13/05/2017.
} 
Mehlecke e Silva (2017), que apresenta dois relatos de experiência sobre a formação continuada de professores para atuar na Educação a Distância On-line em dois diferentes cenários de formação: os AVAs Eduline associado ao Google Sala de Aula e o Moodle associado ao Sistema Integrado de Gestão Acadêmico Administrativa (SIGAA).

Também foram encontrados registros de pesquisas que analisam a formação docente o uso das tecnologias digitais, como as de Maziero (2014), Santana (2011), Andrade (2011) e Campos (2008); e, ainda, a investigação de Rossi (2013) que, para além das pesquisas sobre os usos dos recursos tecnológicos, trata da elaboração de um modelo para o desenvolvimento de softwares educacionais, também com intuito de subsidiar o professor no uso dessas tecnologias.

Associadas às tecnologias digitais, precisam vir as metodologias, que viabilizam o uso didático desse recursos, como relatado em Gomes et al. (2016), no capítulo IV da Série Professor Criativo (construindo cenários de aprendizagem), no qual os autores se propõe a multiplicar experiências de aprendizagem que caracterizam uma educação criativa, priorizando as abordagens metodológicas adotadas para o uso das mais diversas tecnologias em contexto de educação formal e não formal.

Assim, pensando-se nesse novo perfil de alunos da Educação Básica, na necessidade de formação dos professores para o uso de tecnologias digitais e, ainda, especificamente no contexto da formação de professores em cursos de licenciatura a distância, buscou-se propor estratégias de mediação de aprendizagens online, considerando a influência destas na interação dos licenciandos no AVA.

\section{RELATO DA EXPERIÊNCIA}

O referido estudo foi realizado com as turmas das Licenciaturas em Computação, Física, Matemática e Química, através de uma imersão etnográfica no AVA, para realizar observações das interações dos licenciandos dos quatro cursos com os recursos do Moodle. $\mathrm{O}$ estudo foi desenvolvido durante o primeiro semestre de vinculação dos alunos aos seus respectivos cursos, buscando identificar 
quais aspectos influenciam suas interações no AVA, bem como em que medida essa influência aconteceu.

As categorias de análise adotadas no estudo foram criadas a priori, a partir da literatura de referência da área. Foram observados aspectos como a qualificação do tutor (formação, experiência profissional e experiência específica em $\mathrm{EaD}$ ), a qualificação prévia dos alunos (primeira graduação, quais cursos fizeram antes, tempo desde que concluíram o ensino médio), o uso das ferramentas (webconferência, vídeo aulas, fóruns, livros didáticos, envio de tarefas, guia da disciplina, etc), a categorização dos tipos de evasão, correlacionando-os com o desempenho obtido pelos alunos ao final da disciplina.

Posteriormente, foram correlacionados os dados das variáveis observadas para os quatro cursos de licenciatura, buscando verificar se e como a área do curso influencia nos tipos de interações dos alunos.

Para tanto, foram levantados e analisados dados sobre a caracterização da disciplina (comum aos 4 cursos de licenciatura), a caracterização dos atores docentes e a caracterização dos alunos de cada curso.

\section{Caracterização da disciplina}

A disciplina ofertada foi Introdução à Educação a Distância, que é comum à todas as licenciaturas ofertadas na modalidade a distância e que tem como objetivo aplicar as tecnologias da informação e comunicação (TICs) utilizadas na educação a distância, interagindo com as ferramentas, os colegas e os tutores, buscando capacitar o aluno para conhecer os conceitos fundamentais de $\mathrm{EaD}$, interagir no ambiente virtual de aprendizagem, compreender o funcionamento da $\mathrm{EaD}$, reconhecer a importância e a relação entre os papéis da docência compartilhada em $\mathrm{EaD}$ e os objetos digitais de aprendizagem, aplicar os objetos digitais de aprendizagem no ensino de conteúdos específicos, utilizar a tecnologia para melhor realizar o curso a distância e ampliar os conhecimentos sobre avaliação em EaD.

Concomitantemente, cursarem a disciplina 55 alunos da Licenciatura em Computação, 65 alunos da licenciatura em física, 43 alunos da Licenciatura em Matemática e 41 alunos da Licenciatu- 
ra em Química, totalizando 204 alunos distribuídos entre os polos de apoio presencial localizados nas cidades de Angicos, Caraúbas, Grossos, Guamaré, Marcelino Vieira, Natal, Pau dos Ferros e São Gonçalo do Amarante.

O conteúdo da disciplina foi organizado em três unidades, nas quais, para auxiliar o aluno durante o processo de ensino-aprendizagem, foram disponibilizados regularmente recursos como: a) Caderno didático - livro sobre o conteúdo da disciplina elaborado exclusivamente para os cursos de licenciatura a distância da UFERSA e disponível em versão digital; b) Chats/BBB - ferramenta de bate-papo, onde o aluno poderia conversar diretamente com os tutores e professores, facilitando a discussão de textos com roteiro prévio e vivência de aprendizado por meio de uma ação coletiva e interativa; c) fóruns - ferramenta de conversa escrita, onde o aluno postava sua dúvida e o tutor respondia, além de possibilitar compartilhar e discutir textos, temas diversos, links, vídeos, situações problemas e projetos didáticos; d) videoaulas - produzidas pelo professor com o apoio de uma equipe especializada, a fim de tornar mais interativo o processo de aprendizagem, através de aulas práticas gravadas em vídeo.

Os critérios de avaliação adotados contemplaram a proposição de avaliações presenciais, incluindo provas escritas e apresentações de seminários individuais ou em grupo, atividades online são, postadas diretamente no AVA, incluindo resolução de exercícios, questionários e desafios propostos.

\section{Caracterização dos atores docentes}

A professora da disciplina é graduada em Computação, com especialização em Computação, em Gestão Educacional e em Avaliação de Políticas Públicas Educacionais, mestre e doutora em Educação Matemática e Tecnológica, com mais de 20 anos de experiência em ensino e mais de 13 anos de experiência em EaD.

As três tutoras da disciplina são graduadas em Pedagogia, todas com especialização na área de educação e uma com mestrado também na área. Com relação à experiência no ensino, uma delas possui 30 anos, a segunda 20 anos e a terceira 12 anos. Todas elas 
com mais de 3 anos de experiência em EaD, sendo uma delas com experiência anterior nessa mesma disciplina.

\section{Caracterização dos alunos}

Analisando-se os alunos que já possuem outras formações, perguntou-se quem já possui graduação, quem já possui especialização e quem já possui curso técnico.

Analisando-se quanto alunos já são graduados, verificou-se que, dos alunos de computação são $20 \%$, dos alunos de física e matemática são $9 \%$ e dos alunos de química são $7 \%$.

Já os alunos que são especialistas, da computação são 5\%, da física são 6\%, da matemática são $9 \%$ e da química são $7 \%$.

Quanto aos alunos que fizeram curso técnico, da computação e da matemática são $9 \%$, da física são $15 \%$ e da química são $2 \%$.

Quanto ao tempo de conclusão do ensino médio, verificou-se que nenhum dos alunos da química e da computação conclui $\mathrm{o}$ ensino médio no ano anterior, em contrapartida à $2 \%$ da física $\mathrm{e}$ da matemática.

Já $11 \%$ da física, $5 \%$ da química e nenhum dos alunos de matemática e de computação concluíram o ensino médio entre 2 e 5 anos anteriores ao ingresso no ensino superior.

Também $2 \%$ dos alunos da computação e da matemática, $22 \%$ da física e $7 \%$ da química concluíram o ensino médio há mais de 5 anos anteriores ao ingresso no ensino superior.

Em relação aos cursos que mais são citados pelos alunos que já são graduados, apareceram Engenharia Civil, Pedagogia e Física. Já no que se refere aos cursos que mais são citados pelos alunos que já são especialistas, apareceram AEE, Enfermagem e nefrologia, Ensino de matemática e Pedagogia. Enquanto que os cursos que mais são citados pelos alunos que fizeram curso técnico são Segurança do trabalho e Técnico em enfermagem. 


\section{DISCUSSÃO DOS RESULTADOS}

Ao analisar-se os resultados encontrados foram verificados o desempenho dos alunos, considerando somente as notas dos alunos que fizeram as duas avaliações presenciais, a evasão, o uso das ferramentas e as interações no AVA.

\section{Qualificação do desempenho}

$\mathrm{Na}$ análise de desempenho identificou-se o índice de participação dos alunos por curso tanto nas atividades online quanto nas avaliações presenciais.

No que se refere às atividades online, pode-se verificar que o percentual de participação dos alunos da física (55\%) é superior aos das demais licenciaturas (matemática $49 \%$ e química $32 \%$ ), com destaque negativo para a licenciatura em computação, com um índice de participação dos alunos na avaliação presencial de somente $15 \%$.

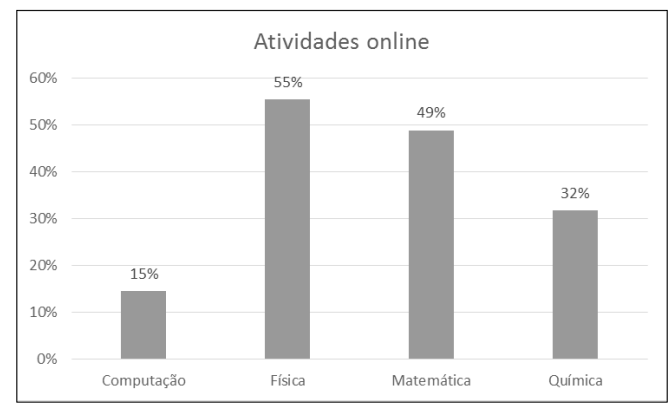

Gráfico 1 - Índice de participação dos alunos nas atividades online Fonte: Elaborado pelas autoras (2018)

Já no que se refere às avaliações presenciais, pode-se verificar que, no geral, o índice de participação dos alunos é maior do que nas avaliações online. Comparando-se o índice de participação dos alunos das diferentes licenciaturas nas avaliações presenciais percebe-se um percentual de participação dos alunos da física (65\%) é superior aos das demais licenciaturas (matemática 51\% e computação 47\%), com destaque negativo para a licenciatura em química, com um índice de participação dos alunos na avaliação presencial de somente $29 \%$. 
Kátia Cilene Silva - Rosângela Gonçalves dos Santos

Ana Karine das Chagas Vieira - Michela Melo da Silva

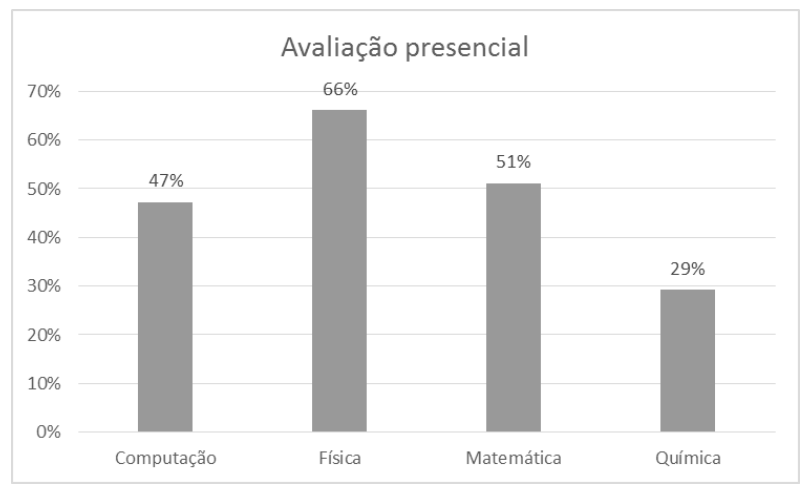

Gráfico 2 - Índice de participação dos alunos nas atividades presenciais Fonte: Elaborado pelas autoras (2018)

Assim, pode-se verificar que, para além dos diferentes níveis de participação dos alunos entre as avaliações online e presenciais, houve uma inversão entre os níveis de participação dos alunos das licenciaturas em química e computação.

\section{Qualificação da evasão}

No que se refere à evasão foram observados os alunos que: a) nunca logaram no Moodle; b) logaram no Moodle, mas nunca fizeram atividades; c) participaram no ambiente, mas não fizeram as duas avaliações presenciais; d) participaram no ambiente, mas não fizeram uma das avaliações presenciais e nem a reposição.

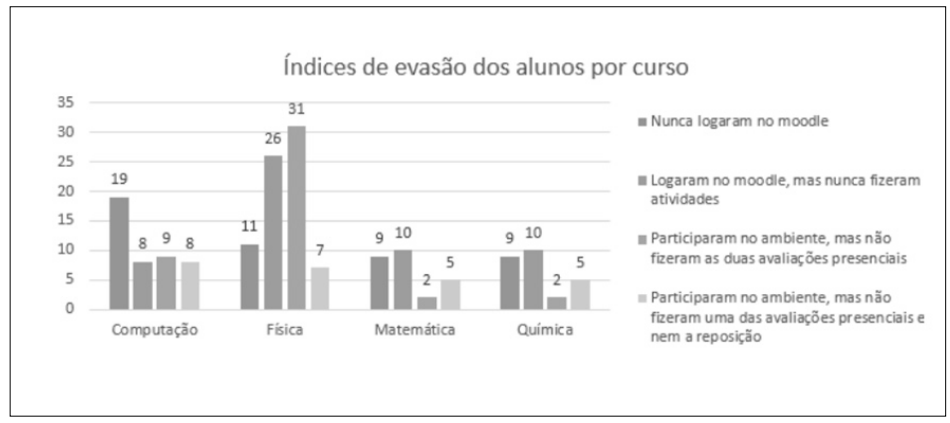

Gráfico 3 - Índice de evasão dos alunos por curso

Fonte: Elaborado pelas autoras (2018) 
Verificando-se a evasão dos alunos das quatro licenciaturas no que se refere aos tipos de atividades, pode-se verificar que, de modo geral, o curso de física foi o que teve maior índice de evasão e os cursos de matemática e química foram os tiveram menor índice de evasão.

\section{Qualificação do uso das ferramentas}

Ao qualificar-se o uso das ferramentas do AVA pelos alunos das quatro licenciaturas identificou-se que não foram apresentadas dificuldades técnicas, tampouco de conteúdo, porém houve desinteresse em usar a ferramenta, principalmente quando os alunos percebiam que não havia nenhuma nota como recompensa pelo uso da ferramenta. No entanto, quando os alunos viram que suas dificuldades foram resolvidas demonstraram um pouco de distorção na interpretação sobre o que seria a webconferência e suas atribuições. O mesmo se percebe em relação aos fóruns temáticos e aos fóruns de dúvidas.

Tal reação dos alunos no uso das ferramentas somente não se reflete no envio de atividades, no acesso ao guia da disciplina, ao Livro didático e as Vídeo aulas.

\section{CONSIDERAÇÕES FINAIS}

Como resultados importantes pode-se citar o diagnóstico do uso das ferramentas pelos licenciandos, considerando dificuldades técnicas, desinteresse em usar, dificuldades com o conteúdo e com a compreensão/interpretação de texto e enunciados, bem como a qualificação das interações identificando possíveis motivos para cada um deles ocorrer, dado a influência da área do curso e dos demais aspectos observados.

Considera-se, então, que o tema do qual trata o presente artigo é contemporâneo e de relevância para área de educação a distância, pois pode ser utilizado com ponto de partida para um replanejamento da prática pedagógica do professor, tanto no que se refere aos recursos utilizados no ambiente virtual de aprendizagem, quanto a abordagem proposta para utilização de atividades presenciais que garantiram o engajamento dos alunos nas disciplinas atra- 
vés da adoção de uma abordagem híbrida de ensino para os cursos de licenciatura a distância.

\section{REFERÊNCIAS}

ABED (org.). CENSO EAD.BR 2015: Relatório analítico da aprendizagem a distância no Brasil. Curitiba: InterSaberes, 2016.168p.

ANDRADE, L. A. R. Educação a distância e ensino presencial: convergência de tecnologias e práticas educacionais (Tese de Mestrado). Campinas: Unicamp, 2011.

BEHAR, P. A. (Org.). Competências em educação a distância. Porto Alegre, RS: Penso, 2013.

CAMPOS, F. A. C. Tecnologias da informação e da comunicação e a formação de professores: um estudo em cursos de licenciatura de uma universidade privada (Monografia de especialização). Belo Horizonte: UFMG, 2011.

FRANCO, S. K. Apresentação do livro Competências para educação a distância. Porto Alegre, RS: Penso, 2013, p. 11-13.

GOMES, A. S.; BITTENCOURT, I. I.; PONTUAL, T.. Educação criativa: multiplicando experiências para a aprendizagem (Série professor criativo, IV). Recife: Pipa Comunicação, 2016.

MAZIERO, S. M. B. Política e diretrizes para o uso de tecnologias educacionais no Paraná: formação e mediação docente (2003-2013). (Monografia de especialização). Curitiba: UFPR, 2014.

MEHLEQUE, Q. T. C. ; SILVA, K. C. Formação de professores para atuar na ead: planejamento, desenvolvimento e avaliação. In: Congresso Internacional ABED de Educação a Distância, 2017, Foz do Iguaçu. Anais... $23^{\circ}$ Congresso Internacional ABED de Educação a Distância. Rio de Janeiro: ABED, 2017. v. 1.

NETO, E. S; FRANCO, E. S. Os professores e os desafios pedagógicos diante das novas gerações: considerações sobre o presente e o futuro. Revista de Educação do COGEIME, a. 19, n. 36, janeiro/junho 2010.

REZENDE, Flávia. As novas tecnologias na prática pedagógica sob a perspectiva construtivista. Revista ENSAIO - Pesquisa em Educação em Ciências, v. 2, n 1, mar.- 2002, p. 1 a 18. Disponível em: 
http://www.univates.br/virtual/file.php/3345/tecnologias_rezende. pdf Acesso em 15 maio. 2018.

ROSSI, R. QETIC: modelo de qualidade para produtos educacionais baseados nas tecnologias de informação e comunicação (Tese de Doutorado). São Paulo: Universidade Presbiteriana Makenzie, 2013. SANTANA, A. F. R. Educação a distância, políticas públicas e seus desdobramentos na formação de professores (Dissertação de Mestrado). Uberlândia: UFU, 2011.

SILVA, K. C. A atuação docente em cursos superiores de computação e informática a distância: formação docente e estratégias de ensino online. Mossoró: Edufersa, 2016. 


\section{PROJETOS EDUCACIONAIS NA EAD: ORGANIZAÇÃO E PRÁTICA NA EDUCAÇÃO ESCOLAR INDÍGENA EM PERNAMBUCO}

Josivania Maria Alves de Freitas 


\section{INTRODUÇÃO}

O presente artigo aborda sobre Projetos Educacionais na $\mathrm{EaD}$, sua organização e prática na educação escolar indígena em Pernambuco. A narrativa explicativa do trabalho realizado traz o relato experiencial da professora autora do material didático e formadora do curso de aperfeiçoamento a distância- Formação para a Gestão Etnoterritorializada da Educação Escolar Indígena, da Universidade Federal de Pernambuco- Centro Acadêmico do Agreste (CAA), Caruaru-PE.

Discutir sobre a educação a distância vai além de agregar as diferentes abordagens sobre sua importância e necessidade pelo seu potencial inovador, a qual tem se expandido em diversos contextos de aprendizagem por meio das possibilidades das tecnologias digitais, mas também da sustentabilidade e da qualidade do processo de ensino e aprendizagem para os sujeitos envolvidos.

A sustentabilidade e qualidade em EaD é entendida como especificidades que envolvem a formação do professor autor-formador, do professor-tutor, a elaboração do material didático, a orientação didática, pedagógica e metodológica dos cenários de aprendizagem no virtual; considerando contextos educacionais diversos entre eles: cenário para ensino semipresencial, ${ }^{1}$ online, blended learning ou, ensino híbrido, ou seja, conforme a Arquitetura Pedagógica (AP) do curso, o ambiente virtual de aprendizagem(AVA) e o modelo conceitual / teoria didática a ser utilizada na prática pedagógica do modelo metodológico de ensino.

Nessa perspectiva, a Secretaria de Educação do Estado de Pernambuco por meio de suas atribuições, percebendo a luta e resistência dos povos indígenas em buscar uma formação adequada que não exigisse descaracterizar o seu modo de vida, por sua ancestralidade, a qual protege e garante o desenvolvimento sustentável das comunidades indígenas; em 2014, solicitou ao Ministério da Educação (MEC),

1 Semipresencial: modelo de ensino que envolve obrigatoriamente atividades no ambiente virtual e no presencial. Geralmente incumbida de peso avaliativo por porcentagem, ou seja, cada atividade desenvolvida tem um peso avaliativo na dinâmica do processo de ensino-aprendizagem. No contexto da formação indígena em Pernambuco, as atividades desenvolvidas a distância tinham peso de $70 \%$ do curso, e as presenciais $30 \%$. 
uma formação semipresencial através do curso de aperfeiçoamento da Educação Escolar Indígena.

Assim, o curso de aperfeiçoamento "Formação para a Gestão Etnoterritorializada da Educação Escolar Indígena" foi desenvolvido pelo Centro Acadêmico do Agreste (CAA), da Universidade Federal de Pernambuco (UFPE); que em colaboração/parceria com a Secretaria de Educação Continuada, Alfabetização, Diversidade e Inclusão (SECADI), propôs uma formação semipresencial que atendeu aos polos de Arcoverde, Caruaru e Floresta. O qual contemplou os doze (12) povos indígenas em Pernambuco, tendo início entre o período de 2014-2015 e sendo finalizado entre o período de 2016-2017.

A relevância de manter a qualificação de profissionais indígenas que atuam na Educação Escolar Indígena partiu do princípio de sua formação acadêmica, pois, em sua maioria concluíram o ensino superior em centros acadêmicos completamente diferentes do contexto escolar e cultural indígena do qual são oriundos. Logo, os projetos de atuação estratégicos dentro dos princípios políticos de escolarização do povo indígena não são contemplados no currículo formal acadêmico.

Portanto, por compreender que esses profissionais indígenas aldeados não são orientados em seus princípios éticos e territoriais, constituídos nas políticas indigenistas de berço e/ou de língua materna na vida acadêmica; culturalmente entende-se que comprometem a formação de futuras gerações de educandos em processo de escolarização indígena.

Para tanto, é necessário que nas escolas indígenas apreciem diferenciadas construção e reconstrução histórica, política e de concepções autônomas que valorize a língua materna e as ciências; evitando que os laços culturais das futuras gerações sejam rompidos.

Nesse sentido, o módulo desenvolvido para formação da Educação Escolar Indígena a distância priorizou a atuação pedagógica com base em projetos integrativos por Povo, tendo em vista o processo de escolarização indígena e os princípios práticos de uma ação educativa contextualizada.

O material didático intitulado Projeto Integrado e Participativo na Educação Escolar Indígena, escrito para formação de profis- 
sionais indígenas em Pernambuco compõe o quarto capítulo do livro Formação para a Gestão Etnoterritorializada da Educação Escolar Indígena; organizado pelos professores coordenadores da Formação a saber: Jaqueline Barbosa da Silva, Denise Clementino Souza, Everaldo Fernandes da Silva. O livro inclui vários autores e foi publicado pela Editora UFPE/Recife-PE, no segundo semestre de 2018.

Conforme definido na introdução do livro supracitado, o capítulo 4, escrito pela professora formadora do curso de formação, discute o projeto societário dos Povos indígenas de forma contextualizada, tendo destaque as dimensões e modos organizativos e projetuais das políticas indigenistas e de diversidade linguística, cujos estruturantes de gestão alcancem impactos emancipatórios no processo de escolarização.

A partir do capítulo publicado foi formalizado a organização dos módulos de aprendizagem a distância. Os módulos tiveram sua base teórica curricular formativa (ementa) relacionada as questões históricas, sociais e legais fundamentadas na escolarização indígena; com pressuposto nas políticas indigenistas, integradas a metodologia de momentos presenciais e a distância. Assim, efetivando à prática pedagógica através de cenários de aprendizagem na plataforma Moodle.

O objetivo geral do módulo propôs conhecer as diversidades de projetos educacionais na prática pedagógica, e a sua relação com as políticas e a diversidade linguística por meio dos percursos e construções dos seus impactos; bem como os desdobramentos no processo de escolarização dos Povos indígenas por meio das tecnologias, visando às dimensões; organização e prática pedagógica que foram desencadeadas ao longo dos anos.

O direcionamento dos estudos para a formação à distância foi organizado na plataforma Moodle, a partir dos capítulos definidos no material didático da professora autora e formadora. Cada módulo/capítulo informava o que seria estudado/aprendido e, na sequência, a meta que deveria ser atingida ao final de cada proposta didático-pedagógica no ambiente virtual.

O curso de formação foi integrado ao modelo semipresencial e utilizou de quatro recursos fundamentais: a) o material didático (on-line e impresso) produzido pela autora e formadora do curso semipresencial; b) ambiente virtual de aprendizagem com seus de- 
vidos cenários modulares; c) polos presenciais com bibliotecas, laboratórios de áreas específicas e de informática, equipamentos para webconferências e/ou videoconferências; e, d) professor / tutor especializado à disposição dos cursistas on-line e presencialmente.

Dessa forma, será apresentada a estruturação teórica sobre a diversidade de projetos, as dimensões, organização e as estratégias utilizadas na plataforma Moodle que objetivou formar profissionais indígenas aldeados, à prática efetiva para o processo de escolarização de educandos indígenas por Povo.

Assim, a seguir, além da estrutura teórica que fomentou e organizou o curso de formação à distância para o contexto específico, o leitor será direcionado à narrativa experiencial para compreender a estruturação pedagógica de sequências e estratégias didáticas através de possibilidades das tecnologias digitais. E para finalizar as considerações finais

\section{POLÍTICAS DE PLANEJAMENTOS: \\ RELAÇÃO COM OS PROJETOS EDUCACIONAIS}

A abordagem pedagógica para desenvolver projetos educacionais que sejam integrados e participativo na educação escolar indígena, abre um leque de discussão pela relação das políticas públicas para Educação Escolar de uma forma em geral; e alicerçada em um novo paradigma educacional que amplia a prática incluindo o respeito à diversidade linguística, considerando os aspectos de interculturalidade, bilinguismo, multilinguismo e etnicidade em seus diferentes níveis e etapas da educação nacional, torna-se ainda mais desafiador na prática formal.

O desafio da prática está alicerçado a emergente mobilização política indigenista direcionada à proteção de seus territórios e recuperação da autonomia face ao poder tutelar. A partir da mobilização desenvolveram-se, no contexto da diversidade linguística indígena, reflexões e exigências sobre o papel da instituição escolar, visando o processo de continuidade identitária e cultural de desenvolvimento e apoio aos projetos diante do contexto educacional atual (FREITAS, 2018); conforme assegura a Carta Magna (2005): "Na educação esco- 
lar, os povos indígenas tem o direito ao uso de suas línguas maternas e processos próprios de aprendizagem, o respeito e proteção a seus valores e manifestações culturais".

Em consonância com a Política e a Diversidade Linguística Indígena, a LDB 9.394, de 20/12/1996, o artigo 79, enfatiza alguns princípios fundamentais, deixando claro que a União, a partir da colaboração com agências federais de fomento à cultura e de assistência aos índios, deve desenvolver programas para oferta de educação escolar bilíngue e intercultural aos povos indígenas.

A União deve apoiar técnica e financeiramente os sistemas de ensino no provimento da educação intercultural às comunidades indígenas, desenvolvendo programas integrados de ensino e pesquisa [...] com os seguintes objetivos: a) fortalecer as práticas socioculturais e a língua materna de cada comunidade indígena; (b) manter programas de formação de pessoal especializado, destinado à educação escolar nas comunidades indígenas; (c) desenvolver currículos e programas específicos, neles incluindo os conteúdos culturais correspondentes às respectivas comunidades; (d) elaborar e publicar sistematicamente material didático específico e diferenciado (LDB 9.394/96, 2010, p.55-56).

O desenvolvimento de programas integrados de ensino e pesquisa, que dialoguem com os desafios para vivência das políticas de planejamentos e a sua relação com os Projetos Educacionais intercultural das comunidades indígenas instituídos ao papel da União; são fortalecidos a partir da LDB 9394/96 quando atribui, em seu discurso, autonomia suficiente às escolas para organizarem seus respectivos currículos, desde que seja respeitada a base comum para o desenvolvimento do Projeto Político Pedagógicos (PPP).

A ação para o desenvolvimento de projetos educacionais parte do princípio de que o planejamento deve ser de natureza político-social e interdisciplinar no que concerne às ações pedagógicas. Assim, como defendido pela LDB 9394/96 em sua posição pedagógica quando cedeu lugar ao planejamento por objetivos, e que o mesmo atendesse aos requisitos de uma educação de qualidade, o que inclui: experiência prévia, competências, capacidades, atitudes, procedimentos, valores, reflexão crítica; levando-nos a compreensão de que o planejamento anual não pode, nem deve ser apenas um momento isolado no calendário escolar. 
Planejamento é um instrumento que antecipa e constitui o conhecimento numa ação; é, portanto, a reflexão da ação desenvolvida antes e durante uma prática que traduz a distância, o desejo e a realidade do que se propõe na manifestação do saber-fazer.(FREITAS, 2012).

Portanto, cabendo práticas e vivências diversas que são ocultas no currículo formal institucional quando se trata das escolas indígenas. Tornando-se inconcebível planejamento de gestão padrão, totalmente descontextualizado com vivências práticas educacionais que não correspondem, nem colaboram efetiva, nem afetivamente com o contexto cultural da escolarização indígena.

A gestão das escolas indígenas é um conjunto de ações, procedimentos e meios que contribuem para atingir os objetivos da escolarização indígena, zelando pelo Projeto Político Pedagógico e contribuindo para fortalecer os projetos de sociedades dos Povos Indígenas; tendo em vista que a gestão das escolas é exercida por seus próprios membros comunitários.(FREITAS, 2018).

Para que a escola indígena possa assegurar os eixos do Projeto Político-Pedagógico, através da Gestão de Programas, é necessário que o modelo de gestão das escolas esteja estruturado de acordo com a organização social, política e territorial dos Povos Indígenas. Cada um dos povos indígenas tem um modelo próprio de organização social construído no contexto das relações sociais, históricas, culturais e religiosas, que ainda são vivenciadas atualmente. (FREITAS,2018, p. 137).

Portanto, um sistema escolar que não existe esforço significativo no sentido de transformar, intervir e progredir frente aos problemas e tomadas de decisões políticas educativas de natureza pedagógica, tanto o planejamento quanto a sua relação com os projetos educacionais ficam seriamente comprometidos, ou até mesmo inviabilizado.

Conforme aponta a LDB 9394/96 quando descreve que o planejamento deve ser resultado de ações educativas como: observações, registros, reflexões, sínteses, avaliações e replanejamentos. Dessa forma, o planejamento envolve uma demanda de atividades que precisam estar em sintonia com o projeto político-pedagógico da instituição escolar, visando configurar as novas ações em seus projetos educacionais. 


\section{DIVERSIDADE DE PROJETOS EDUCACIONAIS}

\section{NAS ESCOLAS INDÍGENAS}

As escolas indígenas têm modelos de gestão diferenciados. Nesse sentido, o modelo de gestão escolar e de funcionamento em Pernambuco foi elaborado a partir das decisões políticas de professores (as) indígenas envolvidos no processo e por diversos representantes dos povos indígenas, no Estado; após discussões e frequentes encontros com membros da Comissão de Professores Indígenas de Pernambuco (COPIPE). (FREITAS, 2018).

A proposta foi romper com os modelos de projetos impostos pelo sistema educacional brasileiro, para recriar os próprios desenhos, concepções e métodos de funcionamento, a partir da organização sociopolítica dos Povos indígenas, que estão inseridos e vivenciam o processo de ensino e aprendizagem como direito legalizado em seus diversos formatos.

Todo projeto da escola é, também, um projeto político por estar intimamente articulado ao compromisso sociopolítico com os interesses reais e coletivos da população majoritária. É político, no sentido de compromisso com a formação do cidadão para um tipo de sociedade. [...] $\mathrm{Na}$ dimensão pedagógica reside a possibilidade da efetivação da intencionalidade da escola, que é a formação do cidadão participativo, responsável, compromissado e criativo. Pedagógico, no sentido de definir as ações educativas e as características necessárias às escolas de cumprirem seus propósitos e sua intencionalidade (VEIGA, 1996, p. 12).

Assim, os projetos educacionais são compostos de multifaces por possuírem características particulares e específicas, que correspondem a uma determinada proposta, dentro de um percurso teórico, didático e metodológico para sua construção e organização de uma determinada dimensão institucional, como destacado a seguir.

\subsection{Projeto político-pedagógico}

O Projeto Político Pedagógico é constituído em um processo democrático de tomada de decisões, com envolvimento de todos, pela discussão, análise e posicionamento. Contudo, sendo estrutu- 
rando em nível pedagógico e político; cujo objetivo é contemplar a organização do trabalho pedagógico.

Nessa perspectiva o PPP busca superar relações corporativas e autoritárias, de competições e conflitos diminuindo ou tentando eliminar o que o processo da prática educativa identifica e conceitua como fragmentação escolar. (FREITAS,2018, p. 128). Logo, em se tratando da prática, o docente consegue perceber que o projeto em discussão é organizado em dois níveis: o pedagógico e o político, conforme aponta Veiga (1996) diferenciando-os.

O projeto é político porque ao planejar, intencionamos a formação de um determinado tipo de homem, escola e sociedade, levando ao comprometimento da concretização desta intencionalidade; sendo necessária a intervenção nesta direção. $O$ projeto é pedagógico porque é efetivada as concepções através da ação educativa, na qual promove uma reflexão. (FREITAS, 2018).

Por se tratar de um projeto não existem receitas infalíveis, tão pouco prontas e acabadas. Pois pressupõe e, é intensificada por uma busca constante de possibilidades viáveis à efetivação e a motivação do trabalho pedagógico; o que exige um trabalho de pesquisa e reflexão sobre a realidade cultural, étnica e suas dimensões quanto à prática docente pensando numa perspectiva não excludente.

Portanto o projeto político-pedagógico deve ser elaborado, executado e avaliado de forma coletiva, compartilhada e socializada, no qual implica diagnosticar a realidade escolar a partir da realização de levantamentos em conjunto com a comunidade, situação social, econômica, política e cultural da mesma. Conforme descrito na LDB 9394/96, o PPP deve considerar alguns aspectos, dentre eles merecem destaque:

O perfil do profissional a ser formado; objetivos gerais específicos do curso; descrição do currículo pleno oferecido; bibliografia básica; número de vagas e turno de funcionamento; relação de docentes e especificação da composição (Titulação); acervo da biblioteca; apresentação das instalações e equipamentos(Infraestrutura). 


\subsection{Projeto didático e institucional}

No meio educacional, ainda, encontramos uma confusão de conceitos entre os projetos didáticos e projetos institucionais, estratégias estas utilizadas que são bastante significativas, no entanto, pouco internalizada por profissionais em suas dimensões e escolhas na prática pedagógica.

Projeto didático é uma forma de planejamento estratégico para organização do tempo e dos conteúdos, cuja dimensão pedagógica está relacionada/vinculada a uma situação-problema. Seu principal objetivo é articular estratégias didáticas diversas para que o aluno aprenda e dimensione propósitos sociais.

Nessa perspectiva necessita de um produto finalizado para ser apreciado, o que ampliará o sentido às práticas escolares, tornando os sujeitos aprendizes corresponsável pelo processo de ensino e aprendizagem. Assim, evitando a fragmentação de conteúdos curriculares.

Os projetos didáticos ou pedagógicos são planejados e organizados de diversas formas, como sabemos a metodologia de projetos não é algo inédito no meio educacional, pois, em diversos momentos escolares transformou-se em modismo, logo, tornou-se em muitos contextos educacionais centros de interesse. O que é lamentável!

Os projetos institucionais envolvem todos os ciclos de aprendizagem e turnos existentes na instituição escolar, ou seja, todo o público-alvo escolar deverá ser contemplado; visando um mesmo objetivo a partir de propostas de ações educativas para o processo de aprendizagem.

No processo não existe obrigatoriedade de um produto finalizado ou propósito social para realização do trabalho. Contudo, quando no projeto é definido um tema gerador, cada professor deverá organizar e planejar quais conteúdos serão contemplados com base no tema, e quais objetivos deverão atingir.

Assim, as atividades desenvolvidas devem considerar um tema gerador e, que a partir dele desenvolvam temáticas diversas; eliminando o planejamento baseado nas necessidades específicas de aprendizagem por aluno. 


\subsection{Projeto de intervenção}

O Projeto de Intervenção é um plano didático-pedagógica, pois permite a sistematização de ideias oriundas das inquietações do professor na constante produção e reelaboração de projetos educacionais (FREITAS,2018, p.133).

Nesse sentido, permite a concepção teórico-metodológica do docente e a oportunidade de estudar as análises realizadas de forma contínua e sistemática, assim como das situações advindas do contexto escolar, próprio de cada área de ensino, com suas particularidades e especificidades disciplinares.

Portanto, o projeto de Intervenção Pedagógica tem como finalidade delinear a intencionalidade das ações a serem implementadas e contempladas na escola. Tem, nesse sentido, uma relação direta com as atividades curriculares previstas, bem como as produções a serem realizadas.

Assim, o principal objetivo do projeto de intervenção é aprimorar o desempenho dos educandos, visando ampliar e consolidar habilidades para superar níveis de dificuldades. Para tal, a gestão escolar precisa direcionar esforço para viabilizar e colaborar com o processo. A função da gestão escolar é coordenar, planejar, organizar, dirigir e avaliar a ação educativa desenvolvida na escola (CENTRO DE CULTURA LUIZ FREIRE, 2013).

\section{DESIGN METODOLÓGICO: CENÁRIOS NO AVA}

O design metodológico apresentado a seguir, descreve o cenário de aprendizagem desenvolvido no curso de formação continuada a distância de profissionais indígenas, cujo perfil são: professores do ensino fundamental e médio, gestores escolares (diretores e vice-diretores), coordenadores pedagógicos, técnicos dos sistemas públicos de ensino das escolas indígenas do estado de Pernambuco.

Todos oriundos de formações acadêmicas diversas e por lideranças comunitárias dos povos indígenas (coordenadores por Povo, Caciques, etc); envolvidos no processo e pertencentes a doze (12) Povos indígenas aldeados no estado, a saber: Atikum, Fulni-ô, Kam- 
biwá, Kapinawá, Pankará, Entre Serras, Pankararu, Pipipã, Truká, Tuxá, Xukuru e Pankaiuká.

Os quais têm seu processo de escolarização garantido na formação ofertada por 121 escolas distribuídas em áreas indígenas de quinze (15) municípios pernambucanos: Águas Belas, Buíque, Cabrobó, Carnaubeira da Penha, Floresta, Ibimirim, Inajá, Itacuruba, Jatobá, Pesqueira, Petrolândia, Poção, Salgueiro, Tacaratu e Tupanatinga.

Os elementos mediadores que subsidiaram as estratégias didáticas para o processo de ensino e aprendizagem na formação continuada dos diversos profissionais indígenas foram organizados por módulos.

Cada módulo correspondia a um capítulo direcionado no material didático, produzido e disponibilizado na biblioteca on-line do AVA, assim como foi distribuído nos polos presenciais uma semana anterior ao início do curso objetivando uma leitura prévia do módulo a ser vivenciado à distância.

Dessa forma, os três primeiros momentos na plataforma foram organizados a partir do uso de fóruns e chats temáticos estruturados sob as seguintes perspectivas:

a) Momento 1 - Síncrono: Apresentação do profissional no chat temático. No chat todos se apresentaram formalmente e falaram das experiências profissionais nas escolas indígenas. Houve reconhecimento entre os Povos, participação ativa e aprendizagem coletiva sobre as incumbências de cada função ocupada nas escolas indígenas pelos profissionais;

b) Momento 2- Fórum: Contextualização cultural. A atividade solicitava uma ação prática informal em que o cursista se identificasse culturalmente e, no processo, explicasse o porquê da escolha. A ação deveria ser representada a partir de uma música, poema, verso, frase (letra ou áudio), tirinha (verbal), imagem (não verbal), gif (verbal ou não verbal), vídeo (gravado no smartphone pelo cursista) ou pesquisado no Youtube (tempo mínimo 3 e máximo 5 minutos). A exemplo, a professora formadora realizou a abertura com sua contextualização cultural através de um vídeo gravado no smartphone para que o fórum fosse sequenciado colaborativamente; 
c) Momento 3- Fórum: Conhecimentos prévios- Projetos integrados na escola indígena. A atividade solicitava que os profissionais sintetizassem, em um parágrafo, o que compreendiam por prática didática através de projetos integrados na escola indígena. A abertura da sala foi vislumbrada conforme imagem.

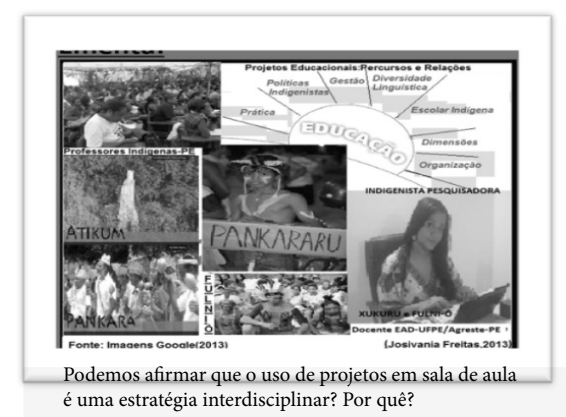

Figura 1 - Print da ementa do curso Fonte: Freitas (2018, p. 123)

A imagem trazia um mapa mental para articulação das ideias sobre a integração dos projetos, proporcionando a colaboração no fórum. A cada duas postagens no fórum uma intervenção colaborativa acontecia entre os profissionais, tutores e professora formadora.

\subsection{Aplicação e discussão dos módulos}

Os cenários desenvolvidos para o curso de formação foram estruturados por banners que direcionaram cinco (5) módulos com propostas e indicações estratégicas estruturadas no ambiente virtual de aprendizagem, vinculado a plataforma Moodle; conforme descrito a seguir.

No Módulo 1- objetivou ampliar conhecimentos sobre as diversidades de projetos na educação e sua relação com as políticas e a diversidade linguística indigenistas. $\mathrm{Na}$ atividade foi desenvolvido um clipping. O que é? Um conjunto de coletâneas realizadas através de reportagens, artigos, entrevistas, pesquisas, matérias de jornais, entre outros, cujo objetivo é abordar conteúdo específicos ou de áreas de interesse do público-leitor; produzindo uma coletânea ou 
acervo de informações através de contribuições diversas, inclusive, em redes digitais.

A proposta para a produção do clipping foi que formassem grupos de cinco (5) participantes no fórum de discussão; escolhessem uma estrutura de Projeto e realizassem uma pesquisa em redes digitais, conforme orientações discutidas nos exemplos de projetos: político- pedagógico, didáticos, institucionais e de intervenção; em seguida o grupo deveria pesquisar uma das formas de projeto e, resumidamente, explicar qual é a proposta do projeto pesquisado, e o que o grupo mudaria no mesmo; para finalizar deveriam organizar os dados e produzir um texto. $\mathrm{O}$ uso de livros didáticos, coleções, revistas, reportagens em redes, etc, também foram disponibilizados, links de acesso, como contribuição aos grupos que desejaram utilizar.

O Módulo 2 - teve como saberes desenvolvidos a compreensão do processo de gestão de programas, a cultura bilíngue dos Fulni-ô e dos impactos da escolarização indígena. Assim, a proposta da atividade foi denominada de Telecine. Os cursistas foram convidados à assistir dois documentários sobre Educação Escolar Indígena de outros estados, disponíveis no Youtube (Ver http://www.youtube.com/watch?v=yyu-PX5KHBk; http://www.youtube.com/watch?v=cWUZCJQZlRw).

Após assistir aos documentários registraram as suas impressões no fórum temático da sala de aula virtual, interagindo e socializando com o professor formador, professor-tutor e colegas; estabelecendo relações entre os filmes a partir da seguinte questão: Há, nos documentários, ações significativas que tenham alguma relação com os princípios do Modelo de Gestão Escolar Indígena em Pernambuco? Fórum: Discutindo Impressões do Telecine em Rede Digital

O Módulo 3 - orientou sobre o Projeto integrado e participativo para educação escolar indígena etnoterritorializada. A atividade solicitada- "Aprendendo e Praticando" - foi desenvolvida no primeiro encontro presencial. Os cursistas discutiram sobre os projetos didáticos a serem desenvolvidos na Escola Indígena, a partir dos Eixos para Escolarização Indígena, a saber: Eixo Terra - Para os povos indígenas, o território é um lugar sagrado, por ser uma habitação natural que abriga os seus antepassados, e os dos seus filhos e filhas. Eixo Identidade - A identidade dos povos indígenas nasce e se constrói em seus territórios. Ela é (re)encontrada através do patri- 
mônio deixado pelos mais velhos. A identidade indígena é sempre (re)elaborada: nas formas de convivência, no espaço e no tempo, a partir do cotidiano e da relação com os encantados, quando lutam pela reconquista da "Mãe Terra". É assim que recriam o universo, a história e os conhecimentos. Eixo História- Conhecer a história dos povos é condição essencial à continuidade das identidades. Sobretudo quando crianças, pois elas precisam ter como referência de vida os seus antepassados, aqueles que vivenciaram uma história de sofrimento, perseguição, mas também de resistências, conquistas e lutas. Eixo Organização - A organização social e política dos povos indígenas é outro elemento importante para sustentação da educação escolar indígena. As organizações internas têm como característica fundamental a garantia da participação de todos os membros da comunidade. Através dessas organizações, são realizados processos de lutas e conquistas, garantindo o direito à escola, à saúde, à política agrícola, dentre outros. Eixo Interculturalidade - É compreensível que cada povo tenha uma cultura própria, diferente uma das outras. Na sociedade em que vivemos, há diferentes formas de vestir, pensar, agir e trabalhar. Cada grupo social tem a tendência de achar que seu modo de vida é o mais correto. Isso tem causado, na história, práticas de intolerância, desrespeito e discriminação (CENTRO DE CULTURA LUIZ FREIRE-CCLF).

No Módulo 4 - objetivou o conhecimento da organização e compreensão da prática pensando a construção de um projeto didático. A atividade solicitada proporcionou a organização de um cronograma para desenvolver projetos. As orientações foram disponibilizadas no Prezi (http://prezi.com/udbhhqh-ojhi/organizacao-de-um--cronograma-para/). Após direcionar os grupos, conforme proposta da escolarização indígena por Eixos e Povos, orientado no capítulo do livro, os cursistas apresentaram o trabalho desenvolvido no segundo encontro presencial. Assim, fizeram uso de recursos e ferramentas tecnológicas diversas, disponíveis no polo da UFPE/ Campus Agreste, Caruaru-PE.

O Módulo 5 - proporcionou uma reflexão sobre o pós-colonialismo a partir da organização e prática de projetos na educação escolar indígena. A proposta da atividade foi a elaboração de um projeto didático, baseado no roteiro disponibilizado no blog da professora 
formadora. Em seguida, os grupos, por distribuídos entre a escolha de um dos Cinco Eixos que norteiam o PPP, anexaram na plataforma a atividade desenvolvida.

\section{CONSIDERAÇÕES FINAIS}

A escola indígena, de acordo com a normatização do Conselho Nacional de Educação, é uma categoria específica de escola, com normas e procedimentos jurídicos próprios, em função do ensino intercultural, multilíngue/bilíngue, específico, diferenciado e comunitário.

No percurso de construção desse subsistema é necessário concretizar um marco legal que contemple efetivamente as instituições educativas de cada Povo indígena, a territorialidade e sua dinâmica sociocultural, a formulação de leis e as normas específicas para esse sistema. Assim, contemplando as peculiaridades da escola indígena e a definição de orçamentos específicos e necessários no processo para fomentar a educação escolar indígena.

Portanto, se os professores que irão atuar na escola indígena não conhecer os princípios práticos vivenciados na ação educativa, enquanto profissionais, estarão propícios a cortar o laço cultural das futuras gerações por não possuir políticas educacionais específicas, que respeitem o território de cada povo indígena. Logo, o curso de formação continuada é um direito constitucional dos profissionais indígenas diante do processo de formação acadêmica.

\section{REFERÊNCIAS}

ALMEIDA, M. R. C. de. Os índios na história do Brasil. Rio de Janeiro: Editora FGV, 2010.

BRASIL. Plano de Desenvolvimento da educação. razões, princípios e programas. Brasília: MEC, 2007.

FREITAS, Josivania Maria Alves de. Projeto Integrado e Participativo na Educação Escolar Indígena. In. SILVA, Jaqueline Barbosa da., SOUZA, Denise Clementino; SILVA, Everaldo Fernandes da. (Orgs.). Formação para a gestão etnoterritorializada para a educação escolar 
indígena. Recife: Editora UFPE, 2018.

. Manifesto em favor de uma educação escolar indígena de qualidade. Brasília: MEC, 2008.

- Gestão das escolas indígenas em Pernambuco: documento preliminar atualizado no seminário de Pesqueira. Centro de Cultura Luiz Freire, 28 a 30 de agosto de 2006.

. Plano de Desenvolvimento da Educação: razões, princípios e programas. Brasília: MEC, 2007.

LDB - Lei de Diretrizes e Bases da Educação Nacional-9.394-96. Ed. Brasília: Câmara dos Deputados, Coordenação Edições Câmara, 2010. Disponível em: <http://bd.camara.gov.br/bd/>.

SECADI. Educação Escolar Indígena: diversidade sociocultural indígena (res)significando a escola. Cadernos Secadi 3. Brasília: MEC, 2007. 
AMBIENTE VIRTUAL DE APRENDIZAGEM EM DISCIPLINAS PRESENCIAIS NO ENSINO SUPERIOR: UM EXEMPLO COM O GOOGLE CLASSROOM

Ernandes Rodrigues do Nascimento Maria Auxiliadora Soares Padilha

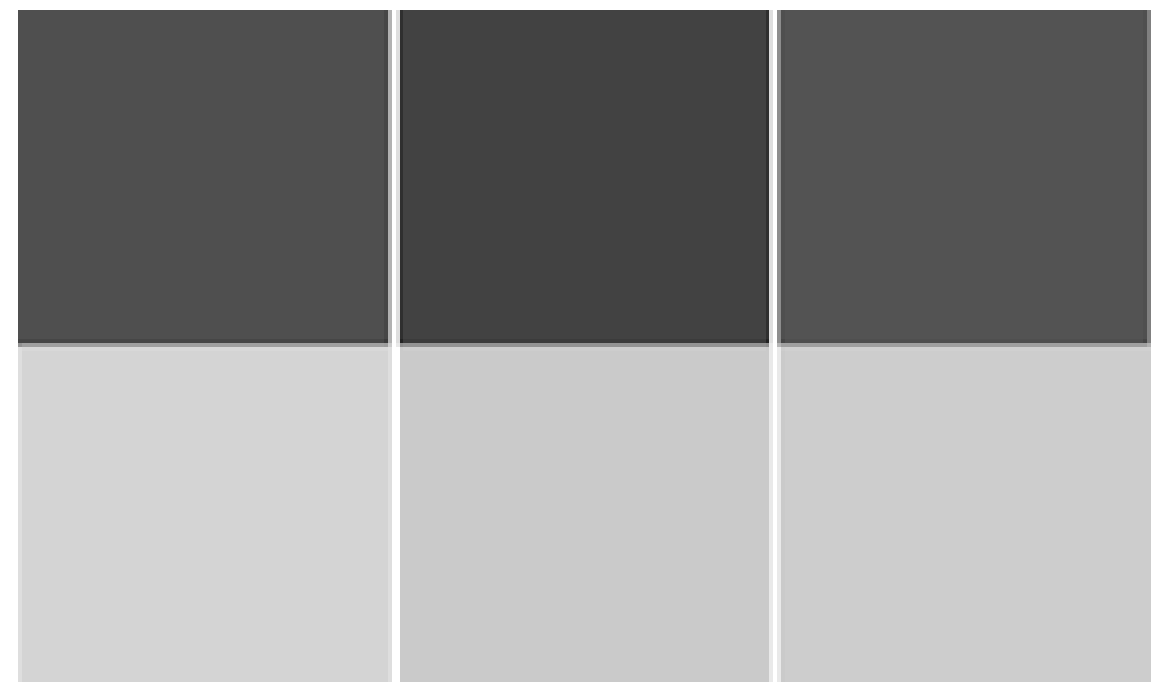




\section{INTRODUÇÃO}

O acesso ao ensino superior nunca foi tão disponível como nos tempos atuais. Em um passado não tão distante, esse nível de formação era exclusivo para as elites brasileiras, oriundas de um ensino fundamental e médio de alta qualidade.

No Brasil, a primeira universidade surgiu por volta dos anos 1912, mas registros mostram que, um século antes, foram criadas as primeiras escolas de medicina, engenharia militar, pintura, escultura, desenho e arquitetura (ALVES, 2007; 2011; ALVES; PASCUETO, 2008; CACETE, 2014; SEMESP, 2015; SOUZA; 2008).

Nas décadas seguintes, à passos lentos, outras universidades foram criadas, mas somente em 1961, por meio da Lei de Diretrizes e Bases da Educação (LDB), o Governo fundou as Universidades Federais em vários estados brasileiros. Contudo, somente após 1970 a busca por esse nível de formação se expandiu.

Pelo fato de as Universidades Estaduais e Federais não conseguirem atender a demanda contínua por formação superior, diversas instituições de ensino superior (IES) foram criadas, sobretudo nos últimos 10 anos, ultrapassando a quantidade de duas mil IES no território nacional, deixando de ser um ambiente próprio para a elite e se popularizando, principalmente a partir de programas de financiamento estudantil do Governo Federal (ALVES, 2007; 2011; ALVES; PASCUETO, 2008; CACETE, 2014; SEMESP, 2015; SOUZA; 2008).

$\mathrm{O}$ crescimento exponencial da educação superior ultrapassou a barreira da presencialidade, estendendo-se também à educação a distância, a qual aumentou mais de 35\% nos últimos anos (SEMESP, 2015). Atualmente, ingressar em uma faculdade ou universidade ficou mais acessível, principalmente pela quantidade de oferta de cursos nas modalidades presenciais, semipresenciais e a distância, tornando o ensino superior mais próximos às classes mais populares.

Os primeiros registros da educação a distância $(\mathrm{EaD})$ datam de 1833, na Suécia, através de um curso de contabilidade. E, dez anos depois, iniciaram os cursos por correspondência na Inglaterra, utilizando-se dos serviços postais. Em 1856 foi a vez dos alemães terem contato com a modalidade e, só em 1874, os cursos a distância che- 
garam aos Estados Unidos da América. Contudo, somente em 1982 a modalidade chegou aos cursos universitários, iniciando pela Universidade de Chicago.

Aos poucos a educação a distância foi se expandindo pelo mundo, chegando ao Brasil em 1891 como curso de datilografia, passando pelas Escolas Internacionais em 1904 e pela rádio e televisão em 1923. Contudo, ela só foi regulamentada para utilização no ensino superior em 1996.

Há mais de 100 anos a educação a distância está presente no Brasil, mas apenas nas últimas décadas voltou a se destacar, graças às tecnologias digitais de informação e comunicação, possibilitando levar a formação superior aos lugares mais remotos, desde que se tenha sinal de TV ou internet. No passado, contava-se com suporte de apostilas, fitas cassetes e correspondências. Hoje, utiliza-se de plataformas digitais, ambientes virtuais modernos, recursos de gamificação, aplicativos para celulares, smartphones e tablets, além das iniciativas com a realidade virtual.

Apesar do avanço tecnológico e das iniciativas das instituições de ensino superior em oferecer uma educação de qualidade, por vezes, muitas variáveis são deixadas de lado, tais como: estilos de aprendizagem, metodologias ativas, gamificação, aprendizagem experiencial, ambientes simulados, adaptative learning, conteúdos personalizados a partir da avaliação diagnóstica, entre outras. Não se utilizar destas variáveis nos ambientes virtuais de aprendizagem significa não acompanhar as mudanças sociais, profissionais e educacionais presentes no contexto atual. Assim, pode-se analisar que o progresso dessa modalidade vem acontecendo, pois a cada dia novos modelos de ambientes educacionais são pensados para potencializar a aprendizagem nessa modalidade.

Por outro lado, desde 2001 as IES podem introduzir disciplinas virtuais nos cursos presenciais, limitando-se à $20 \%$ carga horária total (BRASIL, 2001). A partir dessa data, outras portarias foram publicadas pelo Ministério da Educação (MEC) enfatizando a integração da $\mathrm{EaD}$ no ensino presencial (BRASIL, 2004; 2016), tornando obrigatória a avaliação presencial nas disciplinas virtuais (BRASIL, 2016) e, posteriormente, ampliando essa oferta em até $40 \%$, desde que a IES seja credenciada para a oferta de cursos totalmente a distância e que 
tenha os mesmos cursos em ambas as modalidades, reconhecidos e com conceitos satisfatórios (BRASIL, 2018).

Com a possibilidade de inserir disciplinas virtuais em cursos presenciais, muitas IES perceberam a possibilidade em reduzir custos operacionais criando disciplinas comuns em todos os cursos e transformando-as em virtuais. Contudo, muitos foram os problemas, dentre os quais destacamos: a) utilizaram o mesmo conteúdo das disciplinas presenciais nas ofertas virtuais, sem adaptações, sem considerar as necessidades específicas da modalidade; b) implantaram as disciplinas virtuais sem preparar as pessoas para a mudança, gerando insatisfação e rejeição; c) muitos professores que atuavam em uma única área ou disciplina que foi convertida para o modelo virtual, foram demitidos, pois a IES precisaria de único professor para produzir os conteúdos; d) ambientes virtuais de aprendizagens (AVA) complexos, dificultando a rotina dos estudantes e o trabalho de tutoria dos professores. Sendo esse último item o nosso objetivo de discussão.

A partir da evolução das tecnologias digitais de informação e comunicação e sua integração aos processos de ensino e aprendizagem, os AVA passaram ser utilizados também nas disciplinas presenciais, dando suporte aos professores e estudantes para compartilhamento de conteúdo e extensão da própria aprendizagem. Assim, os ambientes virtuais de aprendizagem deixaram de ser exclusivos da educação a distância ou das disciplinas virtuais e passam a fazer do cotidiano da educação superior.

Nascimento (2013) apresenta alguns indicadores de qualidade e faz um comparativo entre os LMS (Learning Management System) - Sistemas de Gestão da Aprendizagem) utilizados por oito IES durante janeiro e fevereiro de 2010, destacando pontos importantes e essenciais em todo o processo de aprendizagem virtual. Porém, nos últimos dez anos, diversos outros LMS foram criados ou ganharam força no mercado educacional, especialmente pelo aumento da oferta da educação a distância, dentre os quais destacamos: Blackboard - um dos AVA mais caros comercializados no Brasil, Canvas - LSM Americano e recém chegado ao país, EdModo - AVA criado nos EUA e disponibilizado gratuitamente para uso por professores e estudantes, Google Classroom - Sala de aula virtual criada pelo Google e que vem ganhando destaque entre professores, por sua facilidade de uso, por ser intuitivo aos estudantes. 
Contudo, apesar de muitas IES ainda não terem implementado um AVA institucionalmente, vários professores, por conta própria, utilizam diversas ferramentas tecnológicas na condução de suas aulas, dentre elas encontramos o Google Classroom, o que nos levou a seguinte inquietação: quais são os desafios enfrentados pelos professores e estudantes ao utilizarem a sala de aula Google?

Foi objetivo desta pesquisa conhecer os desafios enfrentados pelos professores e estudantes ao organizarem suas aulas por meio do Google Classroom, além de identificar as potencialidade e fragilidades dessa sala de aula virtual.

\section{AMBIENTES VIRTUAIS DE APRENDIZAGEM}

Os Ambientes Virtuais de Aprendizagem - AVA - são LMS (Learning Management System), sistemas de gestão de aprendizagem, desenvolvidos para utilização via web por meio de qualquer browser. Normalmente eram utilizados, exclusivamente, como espaços de aprendizagens para cursos totalmente on-line. Hoje, além do seu papel essencial à EAD, também é utilizado em aulas presenciais como suporte tecnológico ao trabalho docente, onde serão publicados e compartilhados conteúdos, realizadas atividades formativas, realizados fóruns de dúvidas, etc.

De acordo com Ribeiro, Mendonça e Mendonça (2007, p. 3):

Os Ambientes Virtuais de Aprendizagem são softwares educacionais via internet, destinados a apoiar as atividades de educação à distância. Estes softwares oferecerem um conjunto de tecnologias de informação e comunicação, que permitem desenvolver as atividades no tempo, espaço e ritmo de cada participante.

Com o suporte das tecnologias digitais de informação e comunicação - TDIC, é possível integrar centenas de recursos pedagógicos para potencializar a aprendizagem dos estudantes, tais como: simulação de situações reais, gamificação, áudios e vídeos, atividades colaborativas, dentre outros. Quanto maior for a integração entre as TDIC e os AVAS, maior será a diversidade de recursos e de cenários pedagógicos. 
Ao discutir a integração das TDICz às aulas presenciais, incluindo os AVA, faz-se importante compreender, segundo Kenski (2003, p. 21) que: "O homem transita culturalmente mediado pelas tecnologias que lhes são contemporâneas. Elas transformam suas maneiras de pensar, sentir, agir. Mudam, também, suas formas de se comunicar e de adquirir conhecimentos".

Nos AVA, quando nos referimos à $\mathrm{EaD}$, percebemos como forte a interação entre estudantes, professores, e tutores, além da relação com o conteúdo e atividades a serem desenvolvidas e aprendidas. Normalmente, os AVA contam com ferramentas de gestão e acompanhamento dos cursos/disciplinas, buscando auxiliar o processo de ensino e aprendizagem.

Por outro lado, quando os AVA são utilizados como ferramenta de suporte às disciplinas e cursos presenciais, espera-se que a aprendizagem seja expandida, possibilitando que o professor inclua em seu planejamento pedagógico metodologias ativas, como por exemplo: aula invertida (BERGMANN; SAMS, 2015) e gamificação (BURKER, 2015).

Dentre os diversos fatores de sucesso na educação a distância, as interações se destacam como essenciais, sejam elas síncronas ou assíncronas, normalmente dependem exclusivamente do AVA. Moraes (2002) afirma que a interação entre professores e estudantes, em todas as situações de aprendizagem, é um dos itens que requer total atenção, por ser extremamente importante, pois é por meio dela que acontece a partilha de experiências, a construção de conhecimentos. Por outro lado, na disciplina presencial, a interação é direta, entre professor e estudante em sala de aula, disponibilizando-se no AVA os textos para leitura, os vídeos com explicações complementares, etc.

É importante lembrar que a aprendizagem é um processo que se constrói por meio das interações sociais, conduzindo os estudantes ao desenvolvimento de habilidades e competências, fazendo-se uso da mediação e da linguagem (VYGOTSKY, 2001), passando pelo desequilíbrio, assimilação e acomodação (PIAGET, 1979). Ao mesmo tempo, planejar o ambiente educacional e as etapas necessárias ao aprendizado é essencial (GAGNÉ, 1980), especialmente no contexto atual da sociedade, o qual demanda novas competências pessoais e profissionais. 
No entanto, para que os Ambientes Virtuais de Aprendizagem sejam eficazes e eficientes, devem explorar o máximo das tecnologias digitais de informação e comunicação existentes, dos softwares educacionais, oferecendo ao aluno livre acesso aos recursos necessários para que ele mesmo possa construir o seu conhecimento.

Vesce (2008) explica que os softwares educacionais devem ser projetados a partir de metodologias que contextualizam o processo de ensino e aprendizagem. Eles não são simples programas de computador, mas um sistema que envolva recursos de interação, possibilitando ao aluno desenvolver sua cognição, por meio de desafios e estímulos. Para tal, precisa-se de uma equipe multidisciplinar e um Projeto Político Pedagógico que transcreva as diferenças inerentes à aprendizagem por meio de recursos digitais, discussão esta que corrobora com Almeida (2010) ao abordar a emergência para a construção de um web currículo.

De acordo com Nascimento (2013), para que um AVA atenda às reais necessidades de formação, precisa-se incluir: a) Exercício e Prática: pode funcionar como uma avaliação diagnóstica; um teste de conhecimentos; uma simulação que demande determinada prática; pode integrar tentativas de erros e acertos, conduzindo o estudante ao desenvolvimento da sua aprendizagem, incluindo níveis diferentes de dificuldade. b) Tutorial: pode apresentar a resolução de uma questão ou o uso de uma nova ferramenta. c) Jogos educacionais: trazendo desafios que possam ser superados; testando habilidades cognitivas e motoras; memorização, quando importante para a formação. d) Hipertextos e Hiperdocumentos: conectando partes de textos para que o estudante escolha o caminho a seguir; conectando itens que estão fora do AVA, como vídeos do YouTube, artigos científicos em periódicos, mapas virtuais de cidades e países. e) Recursos Visuais: dimensionar o tamanho e tipo de fonte; utilizar as cores de forma adequada e criando possibilidades para inclusão (ex. pessoas daltônicas). f) Métodos e Critérios de Avaliação: utilização de avaliação prévia, diagnóstica, formativa e somativa, enriquecendo as formas de conhecer e mensurar a aprendizagem do estudante, fornecendo ao professor indicadores para a gestão do seu trabalho.

Ao mesmo tempo, precisa-se refletir sobre os indicadores de qualidade que venham a servir para melhorar o AVA e os recursos 
disponíveis, especialmente: as condições de acessibilidade; a clareza e simplicidade nos textos, vídeos e comunicações; a consistência entre o projeto pedagógico, o perfil do egresso e os conteúdos disponibilizados; o acompanhamento efetivo do desempenho e desenvolvimento dos estudantes; a flexibilidade e o respeito ao ritmo dos estudantes, possibilitando que eles possam escolher os melhores caminhos para sua aprendizagem; e a quantidade de conteúdo, evitando excessos e sobrecargas ou que venham a deixar os estudantes ociosos, sentindo-se abandonados.

\section{PERCURSO METODOLÓGICO}

Esta pesquisa qualitativa foi desenvolvida a partir de um estudo de caso (YIN, 2015), utilizando-se da observação participante (ANGROSINO, 2009), com o propósito de descrever os desafios enfrentados por professores e estudantes ao se utilizar o Google Classroom como ambiente virtual de aprendizagem em uma disciplina de um curso superior presencial.

Foram sujeitos deste estudo sete professores e dez estudantes do curso de administração de uma faculdade instalada na cidade do Recife, na qual foi implantado o pacote Google Suíte, trazendo o Google Classroom como uma das ferramentas disponíveis aos professores e estudantes como sala de aula virtual.

Os dados foram coletados a partir das salas de aula virtuais e dos depoimentos dos professores e dos estudantes durante as reuniões de encerramento de semestre ocorrida em junho de 2019, momento em que o pesquisador esteve presente na condição de professor e observador.

Entre fevereiro e junho de 2019, os professores do referido curso passaram a utilizar em suas aulas o Google Classroom como suporte no processo de ensino e aprendizagem. Durante esse período, tivemos acesso às suas salas virtuais, analisamos a organização e a disposição dos materiais. E, ao final do semestre, durante a reunião de encerramento com os docentes e a última reunião com os líderes de turma, observamos seus comentários quando foi questionado sobre as dificuldades que eles sentiram durante o referido semestre. 


\section{ANÁLISE E DISCUSSÃO DOS RESULTADOS}

Ao analisar o ambiente virtual dos professores, percebemos que apenas 1 dos 7 professores tinha conhecimento sobre design instrucional ou quaisquer outros recursos que o ajudasse a criar a sala virtual e organizar o ambiente. Aos demais, faltavam-lhes experiências com EAD e com AVA.

O Google Classroom é relativamente simples, possuía na época da pesquisa um menu com três opções, atualmente, como pode se ver na figura 1, há quatro opções, sendo:

a) Mural - local que aparecem em formato de avisos e lembretes tudo que se é publicado na sala virtual;

b) Atividades - espaço para o professor publicar materiais para leitura, atividades, fóruns, questionários e avaliações;

c) Pessoas - relação dos professores (pode haver mais de um na mesma sala) e estudantes vinculados e com acesso à sala virtual;

d) Notas - item recente. Funciona como um diário de notas, possibilitando ao professor corrigir as atividades e atribuir as respectivas pontuações.

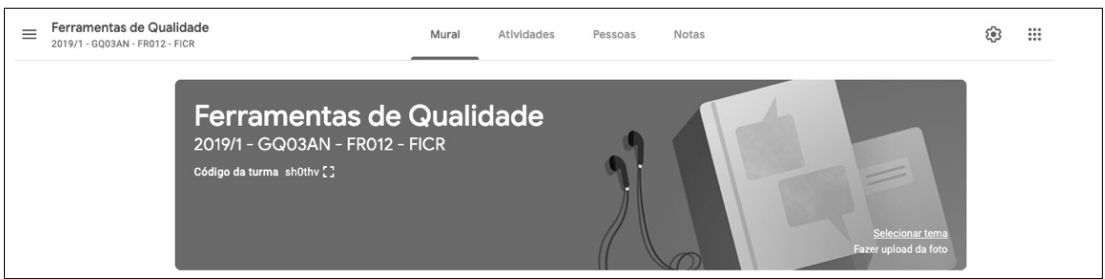

Figura 1: Mural de uma sala Google

Fonte: Elaborado pelos autores (2019)

Além do professor poder trocar a imagem de capa da sala, conforme se percebe na figura 2, ele pode adicionar e excluir estudantes, adicionar materiais, e enviar e-mails aos estudantes, além dos avisos que podem ser publicados no mural. Todo material publicado pode ser para todos os participantes da turma, assim como também pode ser para um ou alguns sujeitos, desde que o professor selecione as pessoas que terão acesso antes de publicar. 


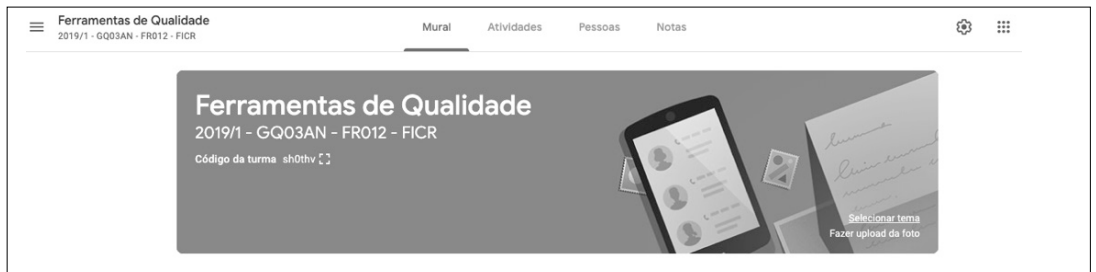

Figura 2: Mural de uma sala Google com imagem de capa trocada Fonte: Elaborada pelos autores (2019)

Ao se analisar a existência de exercícios e práticas, notou-se que em todos as salas havia algumas atividades, mas que apenas o professor com experiência em $\mathrm{EaD}$ tinha utilizado linguagem dialogada, explicando aos estudantes o que se esperava deles. Os demais, conforme figura 3, apenas colocavam a atividade, sem nenhuma orientação para realização da atividade ou uso de linguagem que fizesse o estudante se sentir 'frente a frente' com o professor.

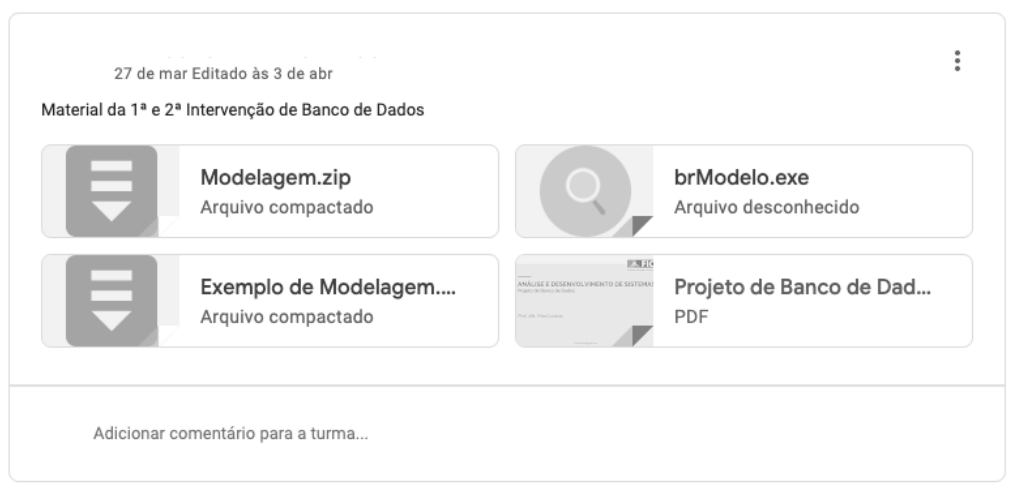

Figura 3: Atividade Publicada

Fonte: Elaborada pelos autores (2019)

O Google Classroom possui recursos de personalização do ambiente, figura 4, dentre os quais há a criação de seções, facilitando a organização e a navegação pela sala. Ainda é possível acessar a agenda do Google e conferir todos os prazos e compromisso e abrir a pasta da turma com todos os materiais publicados e armazenados no Google Drive. 
Ambiente virtual de aprendizagem em disciplinas presenciais no ensino superior: um exemplo com o google classroom

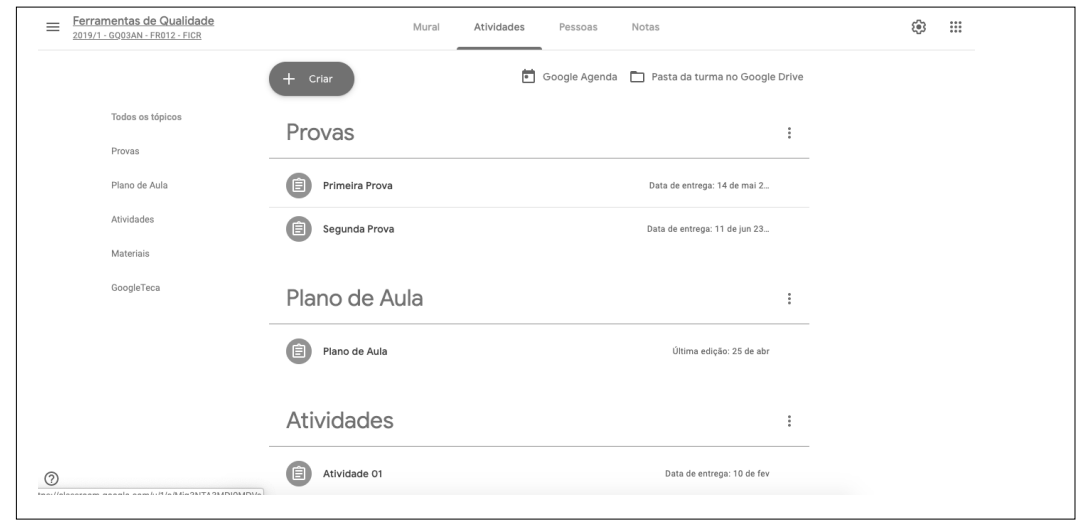

Figura 4: Ambiente das Atividades e dos Materiais

Fonte: Elaborada pelos autores (2019)

No quesito tutorial, os poucos que estavam presentes nas salas virtuais eram link para vídeos disponíveis no YouTube (figura 5) ou algum infográfico da internet, nenhum foi elaborado pelo professor. $\mathrm{E}$, quando se procurou por jogos educacionais ou profissional, nenhum foi encontrado.

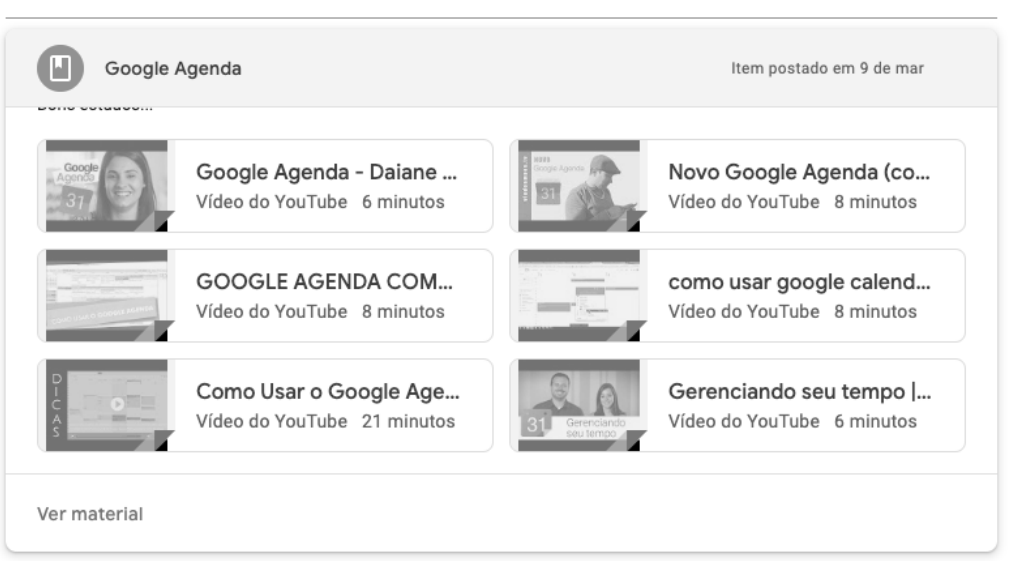

Figura 5: Vídeos publicados na sala virtual Fonte: Elaborada pelos autores (2019)

Por outro lado, em todas as salas havia algum hipertexto ou hiperdocumento (figura 6), ampliando a aprendizagem iniciada em sala de aula ou funcionando como aula invertida. Contudo, em nenhuma sala havia formatação e recursos visuais que cativassem os 
estudantes, assim como também não havia formas variadas de avaliação, sendo predominante a existência de atividades com questões objetivas, buscando apenas identificar se o estudante tinha ou não aprendido determinado conceito, mas não testava sua habilidade ou competência de por em prática o que aprendera.

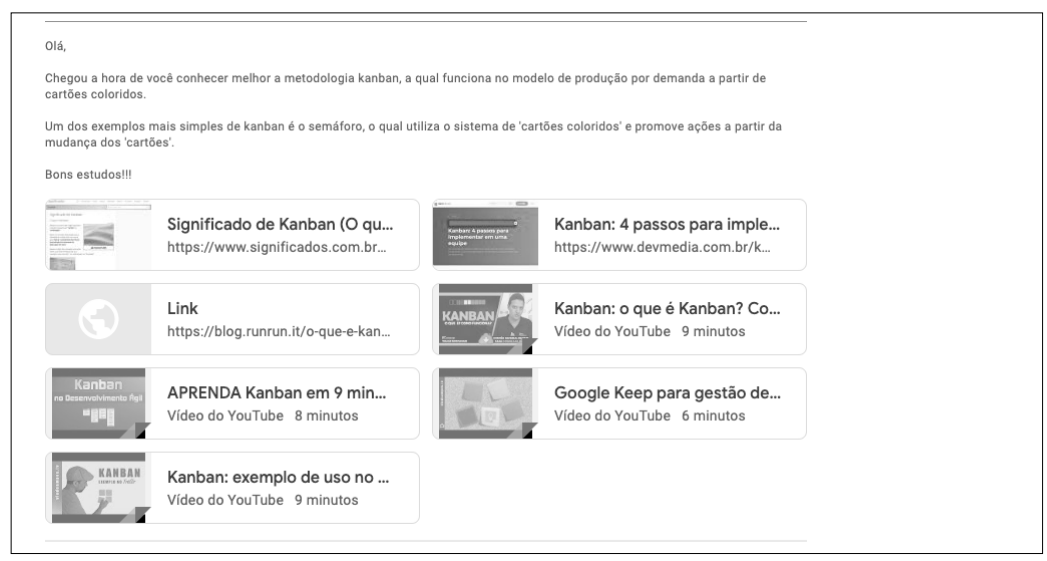

Figura 6: Materiais publicados na sala virtual Fonte: Elaborado pelos autores (2019)

Apesar de todos os professores terem participado de formação para utilização do Google for Education, a falta de prática dificulta o desenvolvimento da habilidade em utilizar o Google Classroom e algumas competências digitais, tais como: curadoria de materiais, facilidade em aprender a utilizar novos recursos tecnológicos, linguagem simples, clara e dialogada, etc.

A curadoria de materiais, em especial os digitais, vem se destacando como uma das funções dos docentes, importantes e essenciais ao contexto atual da educação (CHAGAS; LINHARES; MOTA, 2019), especialmente pelo excesso de conteúdos digitais disponíveis na rede (BOHN; SHORT, 2009; LYMAN; VARIAN, 2000), os quais nem sempre são verídicos ou de qualidade, exigindo do professor a competência para encontrar, triar, selecionar e indicar os materiais digitais mais adequados à formação dos estudantes. No contexto da educação, ao fazer a curadoria digital, o professor precisará fazer a "gestão ativa e preservação de recursos digitais ao longo do seu ciclo de vida completo" (TIBBO; HANK; LEE, 2008, p. 235), garantindo que os estudantes 
tenham acesso aos conteúdos que contribuam com a sua formação integral, além de manter sempre os materiais atualizados ao alcance deles e ensinando-os como desenvolver a sua própria curadoria.

Além de saber integrar as TDIC no processo de ensino e aprendizagem e desenvolver a habilidade de conhecer e aprender a utilizar novas tecnologias continuamente, os docentes também necessitarão desenvolver a competência da escrita clara, simples, objetiva e dialogada, essencial em ambientes virtuais de aprendizagem (BERNARDI; SILVA, 2018), ainda que utilizados como suporte às aulas presenciais, pois no AVA, o docente não está presente e o estudante, precisará ler e compreender o texto sem sentir a ausência do professor, percebendo os exemplos apresentados de forma empática.

$\mathrm{Na}$ visão dos professores, durante a reunião de encerramento do semestre, percebeu-se insegurança no uso de ferramentas do Google Suíte e confirmou-se a falta de habilidade de alguns professores no manuseio do Google Classroom. Todavia, notou-se que eles estavam motivados e engajados em melhorar suas práticas.

Outra dificuldade percebida é que, como normalmente os professores são contratados por determinada carga horária e, no ensino superior, muitas vezes eles atuam em várias organizações, o tempo para planejar e ambientar a sala virtual e o uso das ferramentas do Google Suíte é escasso, dificultando a organização e disposição de uma sala dentro dos moldes previstos para os cursos on-line. Nas IES, quando o AVA é utilizado em cursos a distância ou em disciplinas on-line, normalmente há uma equipe multidisciplinar, composta por designers instrucionais que assumem a ambientação das salas virtuais. Porém, quando o professor decide utilizar um AVA como suporte às suas aulas presenciais, ele termina se encontrando sozinho nessa tarefa: organizar as seções, realizar a curadoria dos materiais digitais, subir esses materiais, criar as atividades utilizando as diversas ferramentas disponíveis, avaliar os estudantes, tirar dúvidas e, em determinados problemas, ajudar os discentes a resolver problemas técnicos de acesso à plataforma.

Contudo, os professores pesquisados estavam felizes por poderem utilizar o Google Classroom, especialmente por ser intuitivo, por estar 'na palma da mão' dos estudantes, por possibilitar atividades colaborativas com as demais ferramentas do G. Suíte e por abrir es- 
paço para o uso de novas metodologias, como por exemplo a aula invertida (BERGMANN; SAMS, 2015), a gamificação (BURKE, 2015), dentre outras.

Ao ouvir os estudantes, percebeu-se que eles estavam integrados ao uso das ferramentas do Google, das quais algumas eles já utilizavam na vida pessoal sem a finalidade acadêmica e outras sequer conheciam antes de iniciar o semestre. Eles estavam engajados e motivados, principalmente por poder estudar e responder suas atividades em qualquer lugar e a qualquer momento, a partir de um celular, tablete ou notebook.

Alguns desses estudantes já haviam utilizados outros ambientes virtuais de aprendizagem em momentos anteriores, resultando no seguinte depoimento:

Eu já havia utilizado outras salas virtuais, como por exemplo o Moodle, porém, a facilidade em utilizar o Google Classroom e sua integração com as outras ferramentas do Google facilitou muito a nossa vida. A tela é simples, a gente sabe o que tem que fazer, está conectada com a agenda e já nos avisa quando tem atividade perto de vencer. Para mim, acho que para meus colegas também, foi uma excelente escolha ter o Google Classroom. (Estudante 1).

Os professores sinalizaram que dentre os principais desafios que eles enfrentaram estava a falta de prática em integrar as diversas ferramentas disponíveis no Google Suíte com as situações pedagógicas, pois exige deles um pensar diferente, saindo da zona de conforto para proporcionar uma aprendizagem inovadora. Percebe-se ainda que em alguns dos professores precisam mudar seu mindset ${ }^{1}$, compreendendo que o ensino tradicional sozinho nem sempre é capaz de desenvolver nos estudantes as competências essenciais ao profissional do futuro.

Por outro, os estudantes mais novos não apresentaram dificuldades ao utilizar o Google Classroom e as demais ferramentas do Google, enquanto alguns mais velhos tiveram dificuldades com a utilização do Google Suíte, demandando da Faculdade a oferta de

\footnotetext{
${ }^{1}$ De acordo com Metring (2016, sp.), Mindset é é o conjunto de pensamentos e crenças que existe dentro de nossa mente e que determina como nos sentimos e nos comportamos. Disponível em: https://administradores.com.br/artigos/mindset-o-que-e-e-como-ele-determina-os-resultados-da-sua-vida
} 
uma disciplina chamada Cultura Digital, a qual teve como objetivo capacitar os estudantes para utilizar as referidas ferramentas. Nesse sentido, observamos que não são apenas os professores que precisam se atualizar e perceber que as mudanças são necessárias para o entendimento de um novo mundo cheio de sentidos imagéticos e digitais. Os alunos nem sempre estão preparados para essas mudanças. Inclusive, porque a universidade atualmente, possui estudantes de várias faixas etárias e classes sociais, e, se a própria universidade não lhes proporciona essa oportunidade de uma formação adequada aos novos tempos, eles chegarão em suas atividades profissionais sem a preparação adequada para os novos espaços de atuação de qualquer área do conhecimento e profissional.

Em relação ao Google Classroom como ambiente virtual de aprendizagem, são fragilidades: a inexistência de relatórios gerenciais; a falta de agrupamento entre estudantes, possibilitando atividades em equipe; a falta de recursos para formatação de textos, com opções de negrito, itálico, etc. Como potencialidades, destaca-se a integração entre todas as ferramentas do Google, Figura 7, possibilitando estratégias didáticas diversas.

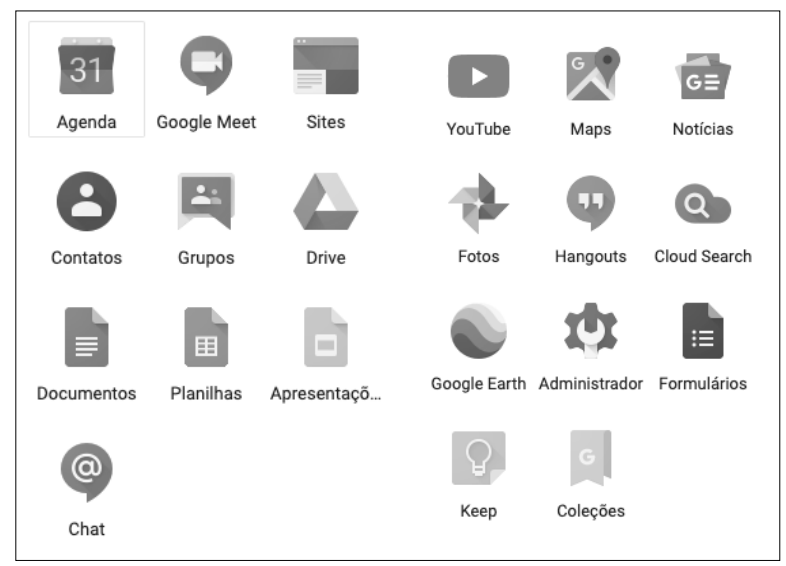

Figura 7: Integração com as ferramentas Google Fonte: Elaborada pelos autores (2019)

Os professores podem integrar documentos, planilhas e apresentações (slides) em uma atividade colaborativa, começando a atividade dentro do Google Classroom e podendo ser concluída a partir 
do Google Drive ou da própria ferramenta utilizada. Há opções de ter um arquivo por estudantes (atividade individual) ou com permissão de edição por todos (atividade coletiva). Pode-se ainda criar formulários, questionários, provas; integrar o Google Keep (sistema de quadro para check list ou roteiro a ser seguido), além de abrir possibilidades de mensagens instantâneas por meio do Google Chat e/ ou videoconferência utilizando o Google Meet.

Assim, quando os professores dominarem essas ferramentas e visualizarem sua utilidade didática no processo de ensino e aprendizagem, eles terão vencido as principais dificuldades vivenciadas neste estudo. Para isso, eles precisam ousar e enfrentar as resistências pessoais, especialmente reconhecendo que o seu mindset não é fixo, e sim um mindset de crescimento, acreditando que é possível, sim, uma prática diferente, uma postura mais afetiva, um espaço de aprendizagem que seja acolhedor e seja organizado para que haja mais ação disponibilidade, tanto do professor, quanto do alunos, para investir numa aprendizagem construtiva e profunda.

\section{CONSIDERAÇÕES FINAIS}

Apesar da fácil integração do Google Classroom com as rotinas acadêmicas, possibilitando que os professores das disciplinas presenciais utilizassem o AVA como suporte às suas aulas, ainda falta desenvolver mais suas habilidades e competências digitais, quebrando o paradigma das aulas puramente tradicionais e expandindo as possibilidades de aprendizagem dos estudantes.

Os professores conhecem as ferramentas digitais apresentadas aqui, foram treinados sobre como utilizar, faltando-lhes agora visualizar as possibilidades pedagógicas que cada uma traz à sua disciplina e às áreas de atuação.

Os professores percebem que suas dificuldades são oriundas da falta de prática, reconhecendo que eles precisam praticar mais, ousar mais, para que a mudança seja profunda e efetiva.

Há ainda a solidão sentida pelos docentes ao planejarem suas atividades e organizarem suas salas virtuais em disciplinas presenciais, pois normalmente eles não contam com uma equipe de suporte e de- 
senvolvimento, ficando sob sua responsabilidade a produção e publicação de todo o material. Esse cenário traz a reflexão sobre a necessidade de se instituir uma equipe multidisciplinar que possa auxiliar os docentes na organização e publicação desses materiais, o que facilitaria a criar padrões entre as salas e garantindo os requisitos mínimos de qualidade necessários a um ambiente virtual de aprendizagem. Além de investimentos, pelas instituições, na ampliação da carga horária de planejamento e elaboração de material didático pelos professores.

Os estudantes entendem que foi uma das tecnologias digitais, depois da $w i-f i$, que mais lhes serviram durante o semestre letivo, potencializando a sua aprendizagem e facilitando seus estudos. Contudo, destacaram que com o AVA, os professores terminam passando mais atividades, exigindo deles mais tempo para os estudos e maior dedicação.

Não foi objetivo desta pesquisa mensurar o engajamento dos docentes nem dos estudantes, assim como o seu desempenho, ficando como sugestões para pesquisas futuras, saber quanto os professores e estudantes estão engajados na utilização e integração das tecnologias digitais de informação e comunicação nos processos de ensino e aprendizagem.

Outra oportunidade de pesquisa seria avaliar as dificuldades dos professores em transferirem suas provas e avaliações do modelo físico, tradicional ao modelo digital, assim como conhecer a percepção dos estudantes sobre essas mudanças.

Sugere-se ainda que outras pesquisas sejam feitas com as salas de aula da Microsoft e da Apple, os quais ainda são bastante recentes, demandando novas pesquisas.

\section{REFERÊNCIAS}

ALMEIDA, M. E. B. Integração de Currículo e Tecnologias: a emergência de web currículo. In: ENDIPE, 2010. Disponível em: <https:// www.academia.edu/33937476/INTEGRA\%C3\%87\%C3\%83O_DE_ CURR\%C3\%8DCULO_E_TECNOLOGIAS_A_EMERG\%C3\%8ANCIA_DE_WEB_CURR\%C3\%8DCULO>. Acesso em: 10 Jul. 2019.

ALVES, G. PASCUETO, C. 200 Anos de Ensino Superior. Revista de História. 2008. Disponível em: <http://www.revistadehistoria.com. 
$\mathrm{br} /$ secao/reportagem/200-anos-de-ensino-superior $>$. Acesso em: $15 \mathrm{jul}$. 2016.

ALVES, J. R. M. A História da educação a distância no Brasil. IPAE, 2007. Disponível em: <http://www.ipae.com.br/pub/pt/cme/ cme_82/index.htm>. Acesso em: Jul. 2016.

ALVES, L. Educação a distância: conceitos e história no Brasil e no Mundo. ABED, 2011. Disponível em: <http://www.abed.org.br/revistacientifica/Revista_PDF_Doc/2011/Artigo_07.pdf >. Acesso em: Jul. 2016.

ANGROSINO, M. Etnografia e observação participante. Porto Alegre: Artmed, 2009.

BERGMANN, J. SAMS, A. Sala de aula invertida: uma metodologia ativa de aprendizagem. São Paulo: LCT, 2015.

BERNARDI, M. G. SILVA, M. J. Tutoria: os seus principais desafios. Anais... V Jornada de Didática - IV Seminário de Pesquisa do CEMAD, 2018. Disponível em: <http://www.uel.br/eventos/jornadadidatica/ pages/arquivos/V\%20Jornada\%20de\%20Didatica\%20e\%20IV\%20Seminario\%20de\%20Pesquisa\%20do\%20CEMAD\%20Saberes\%20e\%20 praticas $\% 20 \mathrm{da} \% 20$ docencia\%20-\%20eixo\%203/TUTORIA $\% 20$ OS\%20 SEUS\%20PRINCIPAIS\%20DESAFIOS.pdf>. Acesso em: 16 Ago. 2019.

BOHN, R. E.; SHORT, J. E. How much information? Report on American Consumers. San Diego: University of California, 2009.

BRASIL. Conselho Nacional de Educação, Câmara de Ensino Superior. Resolução no 1, de 11 março de 2016.

BRASIL. Ministério da Educação. Portaria $n^{\circ} 2.253$, de 18 de outubro de 2001. Diário Oficial da União, 19 de outubro de 2001.

BRASIL. Ministério da Educação. Secretaria de Educação a Distância. Portaria n. 4.059, de 10 de dezembro de 2004. Diário Oficial da União, Brasília, 13 dez. 2004. p. 34.

BRASIL. Ministério de Educação. Portaria $n^{\circ} 1.428$, de 28 de dezembro de 2018. Diário Oficial da União, 31 dez. 2018. p. 59.

BURKER, Brian. Gamificar: como a gamificação motiva as pessoas a fazerem coisas extraordinárias. São Paulo: DVS Editora, 2015.

CACETE, N. H. Breve História do Ensino Superior Brasileiro e da Formação de Professores para a Escola Secundária. Revista Educação e Pesquisa. V. 40, no 4, pp. 1061-1076, out/dez, 2014. Disponível em: <http://www. 
scielo.br/pdf/ep/v40n4/aop1109.pdf>. Acesso em: Jul. 2016.

CHAGAS, A. M. LINHARES, R. N. MOTA, M. F. Um olhar plural e heterogêneo na prática da curadoria de conteúdo digital na educação. Anais... Congresso Ibero-Americano em Investigação Qualitativa - CIAIQ, Lisboa, 2019. Disponível em: <https://proceedings.ciaiq.org/index.php/ CIAIQ2019/article/view/2244/2166>. Acesso em: 16 Ago. 2019.

GAGNÉ, R. M. Princípios essenciais da aprendizagem para o ensino. Porto Alegre: Globo, 1980.

KENSKI, Vani Moreira. Gestão e uso das mídias em projetos de educação à distância. Revista e-curriculum, São Paulo, v.1, n.1, dez. 2005. Disponível em: <http://redalyc.uaemex.mx/redalyc/ pdf/766/76610106.pdf>. Acesso em: 28 fev. 2010.

LYMAN, P.; VARIAN, H. R. How much information? The jornal of eletronic publishing, v. 6, n. 2, dec. 2000.

METRING, N. Mindset - O que é e como ele determina os resultados da sua vida? Administradores.com, 2016. Disponível em: $<$ https:// administradores.com.br/artigos/mindset-o-que-e-e-como-ele-determina-os-resultados-da-sua-vida>. Acesso em: 13 Ago. 2019.

MORAES, M. C. (Org). Educação a distância: fundamentos e práticas. Campinas, SP: Unicamp / Nied, 2002.

NASCIMENTO, E. R. Ambiente virtual de aprendizagem: uma reflexão sobre alguns ambientes virtuais utilizados no Brasil. Recife: Bom Livro Editora, 2013.

PIAGET, S. Aprendizagem e conhecimento. Rio de Janeiro: Freitas Bastos, 1979. RIBEIRO, N. E. MENDONÇA, G. A. de A. MENDONÇA, A. F. A importância dos Ambientes Virtuais de aprendizagem na EaD. 2007, Goiás. Disponível em: <http://aveb.univap.br/opencms/opencms/sites/ve2007neo/pt-BR/imagens/27-06-07/Cognitivas/trabalho_115_ alzino_anais.pdf >. Acesso em: 26 fev. 2010.

SEMESP. 2015. Mapa do ensino superior no Brasil. Disponível em: $<$ http://convergenciacom.net/pdf/mapa-ensino-superior-brasil-2015.pdf>. Acesso em: Jul. 2016.

SOUZA, P. N. História do ensino superior. Universia, 2008. Disponível em: <http://universidades.universia.com.br/universidades-brasil/historia-ensino-superior/historia-do-ensino-superior.pdf $>$. Acesso em: Jul. 2016. 
TIBBO, H. R.; HANK, C.; LEE, C. A. Challenges, curricula, and competencies: researcher and practitioner perspectives for informing the development of a digital curation curriculum. Archiving 2008, Bern, 2008. Final Program and Proceedings. Springfield: Society for Imaging Science and Technology, 2008.

VESCE, G. E. P. Softwares educacionais. 2008. Disponível em: <https://www.infoescola.com/informatica/softwares-educacionais/>. Acesso em: Jul. 2011.

VYGOTSKY, L. A construção do pensamento e da linguagem. São Paulo: Martins Fontes, 2001.

YIN, R. K. Estudo de caso: planejamento e métodos. 5. ed. Porto Alegre: Bookman, 2015. 


\section{UMA PROPOSTA DE APRIMORAMENTO DOS XMOOCS POR MEIO DE FOCO NA PESSOA \\ E NAS INTERAÇÕES SOCIOAFETIVAS}

Roges H. Grandi

Leandro K. Wives

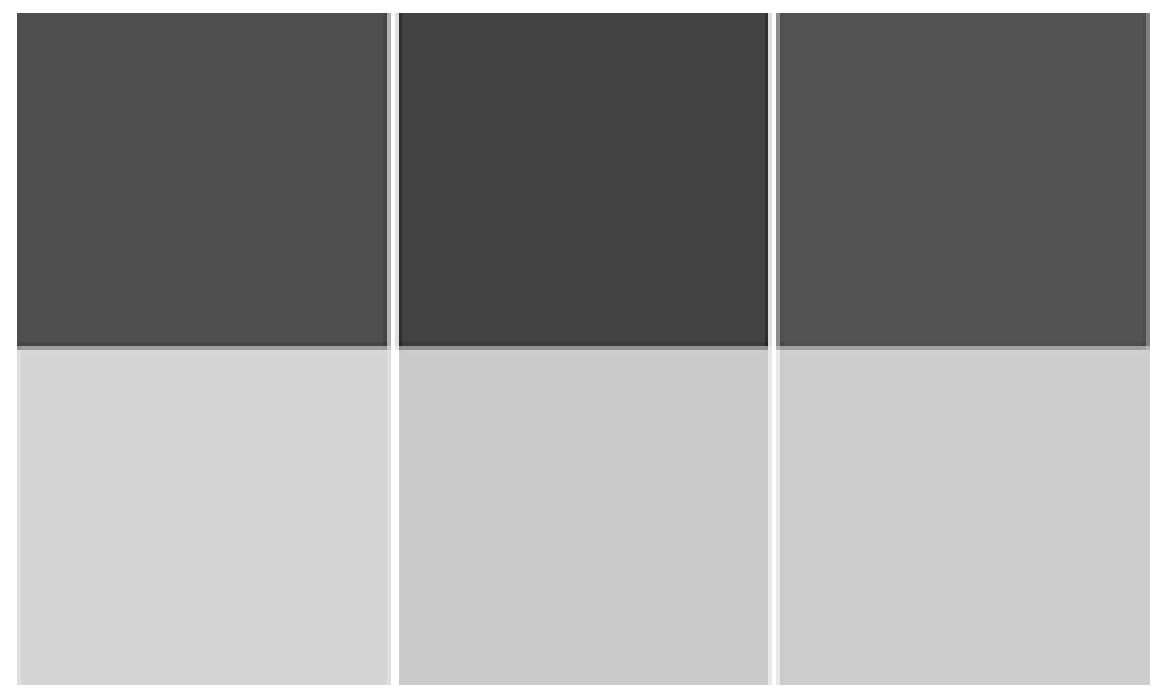




\section{INTRODUÇÃO}

Os primeiros sistemas de gestão de aprendizagem (LMSs) ${ }^{1}$ como o Ekko e o Moodle foram idealizados para apoiar processos tradicionais, geralmente organizados em turmas de quantidade limitada de alunos. Surgiram então os cursos online abertos e massivos (MOOCs) ${ }^{2}$, plataformas educacionais que, diferentemente da geração de software anterior, foram concebidos para oportunizar a aquisição de conhecimentos em proporções mundiais e quantidades massivas de alunos. Os MOOCs tiveram origem no movimento dos recursos educacionais abertos (REA) e foram inicialmente baseados no modelo conectivista (cMOOC). Para o conectivismo (Siemens, 2008):

(a) a aprendizagem é um processo de conectar fontes de informações, as quais podem ser buscadas em dispositivos não-biológicos;

(b) a aquisição de conhecimentos baseia-se na diversidade de opiniões;

(c) a capacidade de saber é mais importante do que se sabe em um determinado momento;

(d) promover e manter conexões é fundamental para a aprendizagem contínua;

(e) o objetivo da aprendizagem é adquirir conhecimentos precisos e atuais;

(f) a capacidade de perceber conexões entre noções, ideias e conceitos é uma habilidade fundamental e

(g) decidir o que aprender é, em si, um processo de aprendizagem.

Universidades de elite norte-americanas perceberam o potencial de uma ferramenta capaz de agregar milhares de alunos por turma. Surgiram então os MOOCs estendidos (xMOOCs) que provêm cursos abertos e online com base em estratégias pedagógicas tradicionais, tendo um tutor (professor) como autoridade, objetivos e conteúdo programático predefinidos, avaliações e certificações. Em um segundo momento, universidades europeias perceberam nos MOOCs uma ferramenta de aprendizagem ao longo da vida. $\mathrm{Na}$ terceira e atual fase, incorporaram-se os cursos de desenvolvimento contínuo profissional (EADTU, 2018). Um breve resumo da história dos MOOCs é apresentado na Figura 1.

${ }^{1}$ Acrônimo em inglês de Learning Management System.

${ }^{2}$ Acrônimo em inglês de Massive Open Online Course. 


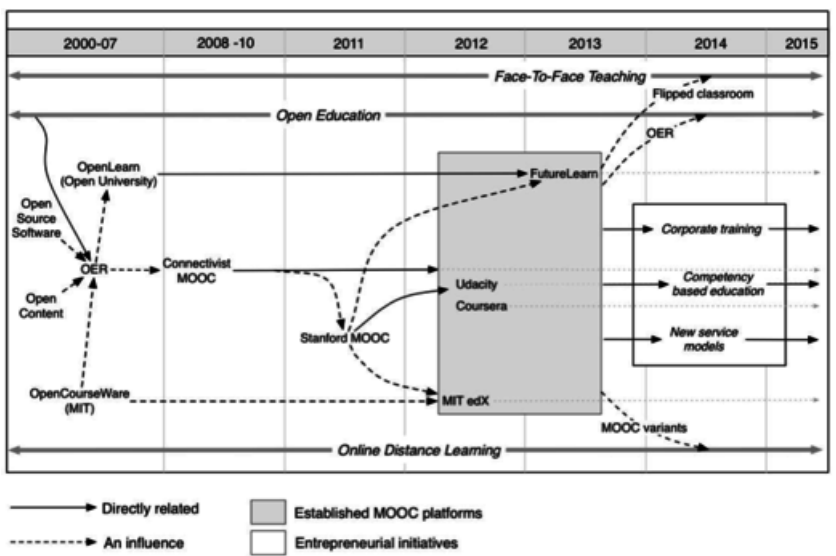

Figura 1. História dos MOOCs - Fonte: Yuan (2015)

Fonte: EADTU, 2018

No quesito quantidade de matrículas, o sucesso das principais plataformas xMOOCs é indubitável: Coursera, edX, XuetangX, Udacity, FutureLearn, todas registram milhões de estudantes. Todavia, assim como a educação à distância $(\mathrm{EaD})$ provocou, e ainda provo$\mathrm{ca}$, questionamentos sobre como realizar melhor a aprendizagem, os xMOOCs com seus cursos globalizados e turmas muitas vezes heterogêneas compostas de quantidades elevadas de alunos nos trazem várias perguntas que permeiam as esferas pedagógica, administrativa e tecnológica, dentre as quais:

i. Personalização: Como prover para cada aluno uma experiência personalizada e otimizada de aprendizagem?

ii. Interatividade: Como promover interações pedagógicas efetivas de colaboração, cooperação e feedback, considerando aspectos afetivos, cognitivos, sociais, tecnológicos e biofisiológicos dos sujeitos do processo de ensino-aprendizagem?

iii. Adaptabilidade: Como tratar a heterogeneidade de nível educacional, idade, necessidades, interesses, cultura, idioma, dialeto, fuso horário em cursos que podem ter milhares de estudantes matriculados? iv. Avaliação: Como utilizar as avaliações mais como instrumento para oportunizar um aprendizado efetivo e, complementarmente, para medição de resultados?

v. Continuidade: A média das taxas de finalização dos cursos é expressivamente baixa. Como elevá-las? 
Ao tempo que se reconhece a importância pedagógica dos MOOCs conectivistas, por uma questão de foco os aprimoramentos aqui são dirigidos aos MOOCs estendidos devido ao alcance que esse modelo tem obtido junto à sociedade.

\section{FOCO NAS PESSOAS E NAS INTERAÇÕES SOCIOAFETIVAS}

A abordagem proposta de focar os $x M O O C s$ nas pessoas e nas interações socioafetivas tem como base aspectos pedagógicos recomendados por Behar (2019, p. 1-5):

O sujeito da $\mathrm{EaD}$ individual é entendido, a partir dos pressupostos de Piaget, como o sujeito psicológico, caracterizado pelo que é particular e subjetivo (Piaget, 1983). Desse modo, o indivíduo é caracterizado em três dimensões: a cognitiva, a afetiva e a social. Todas elas são suportadas pelo sistema biofisiológico (Dolle, 1993). A partir do momento em que as tecnologias digitais passaram a fazer parte da $\mathrm{EAD}$, esse conceito foi adaptado e se fez necessária a construção de uma nova dimensão: a tecnológica.

A primeira análise, que norteia as demais, é o nível de suporte que os xMOOCs têm ou poderiam oferecer às necessidades e aos interesses dos sujeitos da $\mathrm{EaD}$. A importância que se dá em buscar entender e atender aos anseios, aos projetos de vida de cada um provendo atendimento pessoal, personalizado, vem do humanismo de Rogers (1959), para quem a aprendizagem deve servir de instrumento para a autorrealização. O suporte a essas almejos dos sujeitos da $\mathrm{EaD}$ pode ser suprido de três formas:

(1) Potencializando seu ambiente pessoal de aprendizagem (PLE) o qual é formado por um ecossistema de ferramentas (digitais e não digitais) que apoiam sua aprendizagem no dia a dia: na escola, no trabalho, no lazer.

(2) Adicionando características de personalização do ambiente virtual de ensino-aprendizagem (AVEA).

(3) Adotando práticas pedagógicas que favoreçam esses aspectos,

${ }^{3}$ Acrônimo em inglês de Personal Learning Environment. 
visto que ferramentas utilizadas com técnicas inadequadas produzem inevitavelmente resultados insatisfatórios.

A seguir, serão analisados esses três pontos.

\subsection{PLEs integrados aos xMOOCS}

Uma ferramenta que componha o ecossistema de um PLE deve ajudar, tanto quanto possível, as demais ferramentas oferecidas, em uma sinergia que potencializa o auxílio ao aprendiz. O ideal é que cada estudante escolha, livremente, as ferramentas que compõem esse ecossistema. Essas podem ser escolhidas individualmente ou como suíte. Em termos funcionais, uma vantagem das suítes é a integração proporcionada em nível de projeto.

É importante para um aprendiz que seu PLE seja capaz de apoiá-lo nos diversos momentos (temporalidade), nos diversos lugares (ubiquidade), nos diversos processos formais ou informais de (transversalidade). Outra característica relevante de um PLE é que ele evolua com o tempo, tanto como ferramenta (funcionalidades oferecidas), como repositório de informações: o aprendiz vai ampliando, atualizando e corrigindo suas anotações e coleção de objetos de aprendizagem (OAs). Deve-se evitar, igualmente, que coleções de OAs que participaram na construção de conceitos em sua estrutura cognitiva deixem de ser acessíveis ao aprendiz, uma vez que os mesmos poderão ser importantes para novas aquisições cognitivas.

A aprendizagem pessoal é permeada de aspectos afetivos tanto quanto a aprendizagem cooperativa, a colaborativa e os feedbacks, visto que o afeto está enredado nas teias neurológicas da razão por meio da força orientadora dos mecanismos de regulação biológica, dos quais a emoção e o sentimento são expressões notáveis (Damásio, 2012, p. 14-15). As características presentes ou ausentes de PLE em um xMOOC afetam a afetividade e os processos cognitivos em um caminho de duas vias.

Alguns exemplos de dificuldades que um estudante pode encontrar na ausência de apoio digital para apoiar sua aprendizagem pessoal nesta era do big data são mostrados no Quadro 1. Ao deixar de ter acesso a uma referência que utilizou anteriormente, prejudica- 
-se o potencial de rememoramento e acomodação dos subsunçores que acionaram a necessidade de revê-la (Ausubel, 2003).

Aprendizes que refinam suas produções, muitas vezes precisam recorrer à versão anterior para ver a diferença evolutiva e, por vezes, reverter. $\mathrm{O}$ estabelecimento de relações entre referências, anotações, mapas construídos, exercícios realizados auxilia os processos de acomodação e assimilação, já diziam Piaget e Gréco (1974). Além dos impactos negativos na qualidade e na produtividade do aprendizado, vários sentimentos de frustração, impotência, ansiedade podem advir das dificuldades de gestão da aprendizagem pessoal.

(1) Que livro foi que eu li mesmo sobre Teoria dos Grafos? Eu vi isto 5 anos atrás, mas não lembro agora.

(2) Onde foi que eu coloquei mesmo aquele mapa mental que eu fiz no semestre passado sobre energia cinética?

(3) Sim, eu vi isso na Internet, acho que foi numa página sobre ...

(4) Pena que este programa não versiona textos! Se eu tivesse a versão que escrevi anteontem ...

(5) Poxa, não tenho mais aqueles exercícios sobre Gestão de Projetos. Seria bom refazer agora que vou fazer a prova de certificação.

(6) Esses assuntos são interligados. Que pena que não tenho um programa para organizar e evoluir minhas anotações de uma forma integrada.

(7) Que chato que o professor pede para escrever as referências na forma da ABNT. Nem sei direito como fazer isso.

(8) Não devia ter jogado o caderno de TGA fora. Tinha umas dicas valiosas do professor que gostaria de me reler.

(9) Legal esta viagem! É bem como o professor de história falou. Se eu achar o PowerPoint dele vou comparar com as fotos que estou tirando,

(10) Construí vários mapas conceituais sobre Gestão Financeira. Seria bom se pudesse interligá-los e ver o resultado.

(11) Legal o texto deste site. Seria bom se eu pudesse guardar a página e destacar o que é mais importante.

Quadro 1. Exemplos de dificuldades enfrentadas por aprendizes na ausência de PLE

Fonte: Os Autores 
Existem múltiplas possibilidades de organização de suítes de ferramentas para suprir aprendizagem pessoal, colaborativa, cooperativa e feedbacks. A Tabela 1 apresenta um conjunto de ferramentas PLE selecionadas com a finalidade de potencializar variáveis que alteram as aquisições cognitivas do aprendiz (Bloom, 1984), na ótica da aprendizagem pessoal. Análise semelhante em relação a essa suíte será apresentada adiante na ótica das interações socioafetivas.

\begin{tabular}{|c|c|c|}
\hline $\begin{array}{l}\text { Ferramenta } \\
\text { xMOOC/PLE }\end{array}$ & Uso Pedagógico: Necessidades Pessoais & \begin{tabular}{|l|} 
Variável de \\
Bloom $(1984$, p. 4)
\end{tabular} \\
\hline Calendário & $\begin{array}{l}\text { Organização do tempo. É automaticamente } \\
\text { atualizado a cada inclusão, alteração ou ex- } \\
\text { clusão de evento dos cursos em que estiver } \\
\text { matriculado. Permite registro de eventos ex- } \\
\text { ternos para fornecer uma visão unificada das } \\
\text { atividades planejadas. }\end{array}$ & $\begin{array}{l}\text { Tempo de estudo } \\
\text { dedicado à aprendi- } \\
\text { zagem. }\end{array}$ \\
\hline Biblioteca & $\begin{array}{l}\text { Gestão dos OAs. Coleciona todos OAs forne- } \\
\text { cidos pelos cursos, incluindo textos, recursos } \\
\text { multimídia, softwares. Permite registro de } \\
\text { MAs externos, formando um repositório uni- } \\
\text { ficado. Inclui metadados e funcionalidades de: } \\
\text { (a) sistemas de gestão de referências e citações } \\
\text { e (b) social bookmarking. }\end{array}$ & $\begin{array}{l}\text { Aprimoramento da } \\
\text { leitura e dos estudos. }\end{array}$ \\
\hline Wiki & $\begin{array}{l}\text { Gestão de conteúdos. Permite ao estudante } \\
\text { gerir evolutivamente seus conteúdos, tornan- } \\
\text { do-se um caderno eletrônico pessoal, atualizá- } \\
\text { vel e unificado. Integra-se com a biblioteca, os } \\
\text { mapas mentais e os mapas conceituais. }\end{array}$ & $\begin{array}{l}\text { Pré-requisitos cogniti- } \\
\text { vos iniciais. }\end{array}$ \\
\hline $\begin{array}{l}\text { Banco de ques- } \\
\text { tões }\end{array}$ & $\begin{array}{l}\text { Apoio a reflexões. Permite ao aprendiz refletir } \\
\text { sobre conteúdos realizando variados exercí- } \\
\text { cios. Possui metadados que permite organizá- } \\
\text {-los por tipo, conteúdo, nível de dificuldade e } \\
\text { cursos vinculados. Registra os exercícios que } \\
\text { foram realizados com sucesso ou insucesso, as } \\
\text { respectivas datas e horários para que o apren- } \\
\text { diz possa perceber a sua evolução ao longo do } \\
\text { tempo. }\end{array}$ & $\begin{array}{l}\text { Reforço. } \\
\text { Questões de ordem } \\
\text { superior. }\end{array}$ \\
\hline $\begin{array}{l}\text { Editor de mapas } \\
\text { mentais }\end{array}$ & $\begin{array}{l}\text { Apoio a reflexões. Permite ao aluno que exer- } \\
\text { cite o relacionamento conceitual entre ideias e } \\
\text { conceitos, formando um contexto. }\end{array}$ & $\begin{array}{l}\text { Organizador avançado } \\
\text { da estrutura cognitiva. }\end{array}$ \\
\hline $\begin{array}{l}\text { Editor de mapas } \\
\text { conceituais }\end{array}$ & $\begin{array}{l}\text { Apoio a reflexões. Permite ao aluno que exer- } \\
\text { cite o relacionamento conceitual entre ideias e } \\
\text { conceitos, capacitando a formação de propo- } \\
\text { sições lógicas (Moreira, 2012). }\end{array}$ & $\begin{array}{l}\text { Organizador avançado } \\
\text { da estrutura cognitiva. }\end{array}$ \\
\hline
\end{tabular}

Tabela 1. Suíte de Ferramentas xMOOC/PLE - Uso Pessoal.

Fonte: os autores 
A Figura 2 apresenta interações em nível de aprendizagem pessoal das ferramentas que compõem a suíte da Tabela 1 . O calendário pessoal registra eventos internos (xMOOC) e externos, colaborando com o tempo que o aprendiz dedica aos seus estudos. A biblioteca registra objetos de aprendizagem internos e externos, exercendo a função direta de apoiar a leitura e os estudos. Com a função agregada de prover funcionalidades de sistemas de referências e citações, enriquece conteúdos wiki, mapas mentais e conceituais, associa referências a exercícios.

Serve também para gestão de recursos web, colecionando links, permitindo destacar trechos de páginas e realizar anotações. $\mathrm{O}$ wiki permite registrar conteúdos unificados formando um caderno pessoal em que o aprendiz registra e evolui artigos sobre os mais diversos estudos que considera importante registrar. Cadernos e anotações (eletrônicos ou não), exercícios de escrita sobre variados temas servem para formar pré-requisitos cognitivos iniciais para a aquisição de novos conhecimentos.

Os mapas conceituais são apontados por Ausubel (2003), Novak e Cañas (2008) e Moreira (2012) como organizadores avançados da estrutura cognitiva. Os mapas mentais também servem para organizar conceitos, sendo que os mapas conceituais são estruturados por proposições lógicas enquanto que os mapas mentais por contexto.

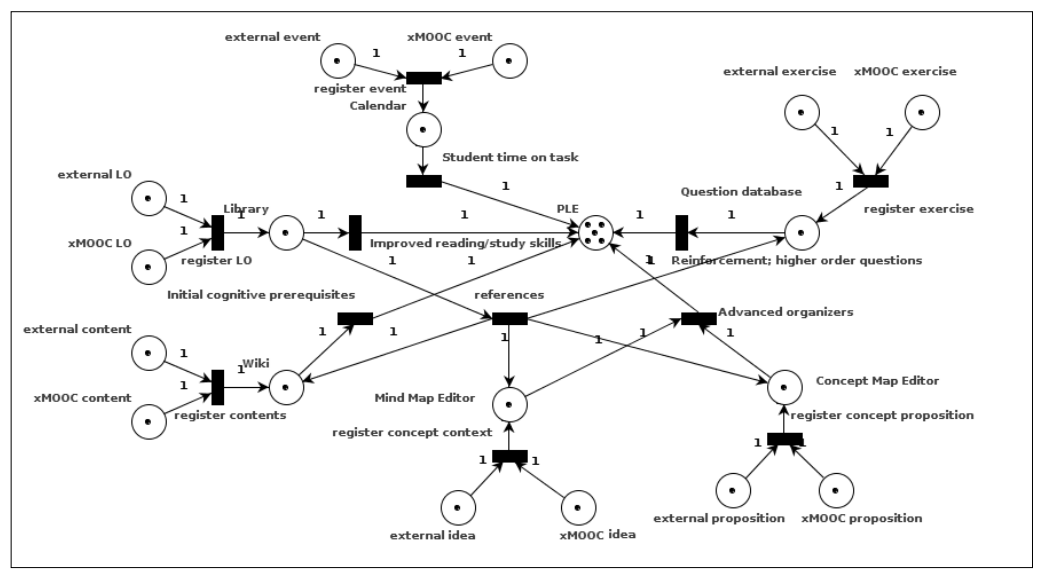

Figura 2. Formação de uma suíte xMOOC/PLE e suas interações de aprendizagem pessoal Fonte: Os autores 
Reforça-se a importância para a aprendizagem significativa, ao longo da vida, da disponibilização dos recursos xMOOC/PLE após a conclusão de cursos. A referência cognitiva de materiais já utilizados e, portanto, com significação para a estrutura cognitiva do sujeito, é relevante para o acionamento de subsunçores.

\subsection{Personalização nas Interações com xMOOCs}

A personalização da experiência do usuário está cada vez mais presente, especialmente após o advento da Web 3.0 (Behar 2019, p. 2). Em sistemas educacionais, essa personalização pode se dar por meio de sistemas tutores inteligentes (STIs), sistemas de recomendação educacionais (SREs) e funções adaptativas que, com base em abstrações de perfis dos aprendentes, oferecem conteúdos, trajetórias e interações personalizadas. As abstrações de perfis devem considerar: - os cinco aspectos dos sujeitos da EAD: biofisiológico, cognitivo, social, afetivo e tecnológico (Behar, 2019);

- a diversidade pedagógica, a multiculturalidade e a interculturalidade (Santos, 2005);

- o conceito de educação inclusiva: concepção de ensino que objetiva garantir o direito de todos à educação (UNESCO, 2019).

A adaptabilidade está associada a características físicas, aos hábitos de uso de tecnologias e aspectos afetivos. Características físicas genéticas ou adquiridas podem demandar uma série de recursos adaptativos em dispositivos de entrada e saída, tamanho e formas de imagens, alterativas para audição de mídias para resolver ou minimizar problemas motores, de acuidade visual, acuidade auditiva. Os hábitos de uso de tecnologias, assim como os afetivos, relacionam-se com o letramento digital e aos gostos, às preferências pessoais. Idosos com pouca interação com computadores de mesa, notebooks e celulares podem ter problemas em operar quaisquer desses aparelhos. Jovens habituados com celulares podem ter dificuldades em operar computadores de mesa e notebooks. Usuários Android podem ter dificuldades em utilizar iOS, e vice-versa. Quando uma dificuldade relacionada ao letramento ou aos hábitos digitais se apresentam ao aprendiz, essa pode alterar seus estados de humor e sentimentos de 
capacidade, influenciando suas atividades cognitivas. Dessa forma, é importante que as interfaces sejam adaptativas (no sentido amplo e universal da palavra) e responsivas, para atender usuários em diversas plataformas tecnológicas.

\subsection{Interações afeto cognitivas nos xMOOCs}

Uma característica importante dos PLEs - a da capacidade de realizar interações pedagógicas por meio de colaborações, cooperações e feedbacks - é tratada nesta seção, também com a finalidade de potencializar variáveis que alteram as aquisições cognitivas do aprendiz (BLOOM, 1984). Existem diversas formas de entender a aprendizagem colaborativa e a cooperativa, não raro causando polêmicas em seminários e congressos. Neste texto, adotaram-se as seguintes designações (BARROS, 1994 apud NITZKE; FRANCO 2002, p. 25):

- Aprendizagem colaborativa: relacionada à contribuição de um sujeito à aprendizagem de outro.

- Aprendizagem cooperativa: abrange o significado de colaboração e envolve trabalho comum visando alcançar um objetivo comum.

Benjamin Bloom percebia um valor muito grande no diagnóstico de dificuldades dos aprendizes que as avaliações proporcionam e no correto uso do feedback para o processo de aprendizagem (Guskey, 2007, p. 11-12). Ao se prover um PLE com capacidades de comunicação síncrona e assíncrona de tutores com tutores, tutores com aprendizes e aprendizes com tutores, forma-se uma comunidade de aprendizagem com feedback potencializado.

O uso efetivo de tecnologias de e-learning requer uma abordagem pedagógica subjacente a qual é, idealmente, centrada no aprendiz para permitir um diálogo continuo, evolutivo, entre os alunos e o tutor (Laurillard, 2002). Tais abordagens centradas no aprendiz emergem da pedagogia socioconstrutivista articulada por Vygotsky (1978) com a ideia de que o diálogo, a orientação, o feedback e as interações sociais são instrumentos de transformação do desenvolvimento potencial em habilidades efetivas (Ehiyazaryan-White, 2012, p. 174).

A Tabela 2 apresenta um conjunto de ferramentas PLE selecionadas com a finalidade de potencializar interações capazes de poten- 
cializar aquisições cognitivas e socioafetivas do aprendiz.

\begin{tabular}{l|l|l}
\hline \multicolumn{1}{c|}{$\begin{array}{c}\text { Ferramenta } \\
\mathbf{x M O O C} / \mathbf{P L E}\end{array}$} & \multicolumn{1}{c|}{ Uso Pedagógico: Interações } & \multicolumn{1}{|c}{$\begin{array}{c}\text { Técnica Pedagógica } \\
\text { Bloom (1984, p. 4) }\end{array}$} \\
\hline $\begin{array}{l}\text { Videoconferência, } \\
\text { teleconferência, } \\
\text { chat }\end{array}$ & $\begin{array}{l}\text { Comunicação síncrona com o tu- } \\
\text { tor. }\end{array}$ & $\begin{array}{l}\text { Instruções de tutoria; } \\
\text { feedback corretivo. }\end{array}$ \\
\cline { 2 - 3 } & $\begin{array}{l}\text { Comunicação síncrona com cole- } \\
\text { gas. }\end{array}$ & $\begin{array}{l}\text { Aprendizagem coopera- } \\
\text { tiva; influência de pares } \\
\text { de grupos. }\end{array}$ \\
\hline $\begin{array}{l}\text { Fóruns, mensa- } \\
\text { gens, } \\
\text { e-mails }\end{array}$ & $\begin{array}{l}\text { Comunicação assíncrona com o } \\
\text { tutor }\end{array}$ & $\begin{array}{l}\text { Instruçôes de tutoria; } \\
\text { feedback corretivo. }\end{array}$ \\
\cline { 2 - 3 } & $\begin{array}{l}\text { Comunicação assíncrona com co-- } \\
\text { legas. }\end{array}$ & $\begin{array}{l}\text { Aprendizagem coopera- } \\
\text { tiva; influência de pares } \\
\text { de grupos. }\end{array}$ \\
\hline
\end{tabular}

Tabela 2. Suíte de Ferramentas xMOOC/PLE - Interações Fonte: Os autores

\section{TRABALHOS RELACIONADOS}

Pesquisas sobre esta temática têm sido realizadas na União Europeia e nos Estados Unidos, que tem dado ênfase a dois aspectos: tratamento das evasões e apoio dos XMOOCs ao longo da vida.

Fidalgo et al. (2013) coletaram na plataforma Miríada X dados referentes a duas edições de um curso sobre software livre e conhecimento aberto. Na primeira edição, os alunos seguiram o processo de ensino-aprendizagem comumente adotado na plataforma e a taxa de finalização do curso foi de apenas $13,47 \%$. Na segunda edição, os pesquisadores intervieram formando uma comunidade de aprendizagem com os alunos do curso, a qual teve à disposição um wiki para organizar tanto o conhecimento empírico proveniente dos OAs disponibilizados pelos conteudistas do curso como o conhecimento holístico gerado durante o curso. A intervenção contou, também, com o uso de redes sociais (LinkedIn, Twitter, Identi.ca e Elgg) para a realização de debates e postagem de comentários. A taxa de finalização passou para $27,8 \%$. Um valor ainda baixo, mas duas vezes maior que a primeira edição. Esse experimento demonstra que com abordagens pedagógicas corretamente aplicadas, pode-se melhorar significativamente as taxas de finalização contribuindo, igualmente, com a sociabilização e a autorrealização dos aprendizes. 
Anders (2015) também entende que os MOOCs estão passando por um processo de amadurecimento e analisa várias teorias pedagógicas em relação aos cursos abertos e online. Compara a abordagem cognitivo-behaviorista de prescrição de conteúdos (xMOOCs) com a conectivista de conteúdos construídos colaborativamente (cMOOCs). Em relação às interações, analisa aspectos da aprendizagem individual, em grupos e em rede. A individual demanda esforços pessoais e, por definição, inclui poucas ações colaborativas, cooperativas e socioafetivas. A aprendizagem por comunidades (grupos) de aprendizagem é social, participativa, contextual. A construção do conhecimento acontece em um processo de socialização que negocia experiências individuais com múltiplas perspectivas. Nas redes, o conhecimento é distribuído, navegável, adaptativo e ativado por meio de interações com pessoas e conteúdos disponíveis. O estilo de ensino-aprendizagem é diferenciado entre pedagógico, andragógico e heutagógico. Neste contexto, a pedagogia é considerada um estilo mais direcionado, controlado por professores e instrutores. Na andragogia o aprendiz organiza os conteúdos que deseja aprender em relação às suas necessidades de desenvolvimento de competências e habilidades. A heutagogia é caracterizada pela autonomia do aprendiz, que determina seus objetivos e escolhe seus processos de aprendizagem. Enfatiza o pensamento crítico e o aprender a aprender. A análise de Anders (2015) concentra-se no aspecto das interações. Considera que o modelo de formação de comunidades (grupos) de aprendizagem consegue responder ao problema de falta interações socioafetivas, de colaboração e de cooperação percebido nos xMOOCs evitando, ao mesmo tempo, a abordagem heutagógica do conectivismo, na qual a responsabilidade pela aprendizagem fica totalmente a cargo do aprendiz.

\section{CONCLUSÕES}

Frente às características atuais dos xMOOCs - Coursera, edX, XuetangX, Udacity, FutureLearn e outros - que possuem foco na gestão dos cursos e não nas necessidades pessoais e interacionais dos estudantes, existe um amplo espectro de oportunidades de aperfeiçoá-los visando torná-las ferramentas mais adaptadas às necessidades de aprendizagem ao longo da vida e de desenvolvimento socioafetivo. 
No aspecto da aprendizagem pessoal, faltam funcionalidades em calendários para registro de atividades transversais, inclusive para dois ou mais cursos sendo realizados na mesma plataforma, demandando aos aprendentes, muitas vezes, um esforço significativo para a gestão de seu tempo. Da mesma forma, carece o oferecimento de uma biblioteca integrada, que permita o registro e classificação de objetos de aprendizagem externos. Outro problema detectado nessas plataformas é a descontinuidade de acesso a recursos após a conclusão de cursos.

Wikis adquirem valor quanto mais forem evoluindo com o tempo. Tanto para uso pessoal como coletivo, esse tipo de ferramenta passa a agregar um grande valor quando oferecida, alimentada e evoluída continuamente em médio e longo prazos. Não se percebe também a presença dessa funcionalidade com essas características nos XMOOCs atuais.

Também percebe-se ausência de visão transversal e continuada de banco de questões, que poderiam permitir ao aprendiz perceber sua evolução ao longo do tempo. Ausentes, também, são os editores de mapas mentais e conceituais, sendo de grande valor para estabelecer relações entre conceitos, reforçando a aprendizagem significativa.

Pouca ênfase se dá, igualmente, às interações cognitivas e socioafetivas em xMOOCs, configurando-se assim em ferramentas mais focadas na aprendizagem individual. O que se oferece nesse contexto são uma continuidade das ferramentas de comunicação preexistentes nos LMSs, tais como fóruns e trocas de mensagens com os tutores. Todavia, ferramentas de aprendizagem cooperativa ou colaborativa são pouco utilizadas. Interações com pares podem reforçar o sentimento de pertencimento e diminuir taxas de evasão, uma das principais fraquezas dessa modalidade.

Percebem-se, portanto, grandes oportunidades de aperfeiçoamentos no mundo dos xMOOCs referentes ao apoio pessoal, cooperativo e colaborativo (interacional) da aprendizagem, em curto prazo e ao longo da vida, conforme revelam estudos que estão sendo realizados na União Europeia e nos Estados Unidos. Tais oportunidades merecem uma análise multidisciplinar, incluindo aspectos pedagógicos, psicológicos, de gestão e tecnologia. 


\section{REFERENCIAS}

ANDERS, A. Theories and applications of massive online open courses (MOOCs): the case for hybrid design. International Review of Research in Open and Distance Learning, v. 16, n. 6, p. 39-61, 2015. AUSUBEL, D. P. Aquisição e retenção de conhecimentos: uma perspectiva cognitiva. Lisboa: Plátano Edições Técnicas, 2003.

BARROS, L. A. Suporte a ambientes distribuídos para aprendizagem cooperativa. 1994. UFRJ, 1994.

BEHAR, P. A. Recomendação pedagógica em educação a distância. Porto Alegre: Penso Editora, 2019.

BLOOM, B. The 2 sigma problem: the search for methods of group instruction as effective as one-to-one tutoring. Educational researcher, v. 13, n. 6, p. 4-16, 1984.

DAMÁSIO, A. R. O erro de Descartes: emoção, razão e o cérebro humano. São Paulo: Letras, Companhia das, 2012.

EADTU. The 2018 OpenupEd Trend Report on MOOCs. 2018. Disponível em: <https://www.openuped.eu/images/Publications/ The_2018_OpenupEd_trend_report_on_MOOCs.pdf $>$.

EHIYAZARYAN-WHITE, E. The Dialogic Potential of ePortfolios: Formative Feedback and Communities of Learning Within a Personal Learning Environment. International Journal of ePortfolio, v. 2, n. 2, p. 173-185, 2012. FIDALGO, Á.; SEIN-ECHALUCE, M. L.; GARCÍA-PEÑALVO, F. J. An integration between $c M O O C$ and $x M O O C$. Anais... II Congreso Internacional sobre Aprendizaje, Innovación y Competitividad (CINAIC 2013), n. Cinaic, p. 481-486, 2013.

GUSKEY, T. R. Closing achievement gaps: revisiting Benjamin S. Bloom's "Learning for Mastery. Journal of advanced academics, v. 19, n. 1, p. 8-31, 2007.

NITZKE, J. A.; FRANCO, S. R. K. Aprendizagem cooperativa: utopia ou possibilidade? Informática na educação: teoria \& prática, v. 5, n. 2, p. 23-30, 2002.

MOREIRA, M. A. Mapas conceituais e aprendizagem significativa. São Paulo: Centauro, 2012. v. 4 Disponível em: <http://moreira. if.ufrgs.br>. 
NOVAK, J. D.; CAÑAS, A. J. The theory underlying concept maps and how to construct and use them. IHMC CmapTools, p. 1-36, 2008.

SANTOS, M. S. dos. Pedagogia da diversidade. São Paulo: Memnon, 2005.

SIEMENS, G. Connectivism. A Learning Theory for the Digital Age. International Journal of Instructional Technology and Distance Learning, v. 39, n. 4, p. 675-685, 2011.

PIAGET, J.; GRÉCO, P. Aprendizagem e conhecimento. Rio de Janeiro: Freitas Bastos, 1974.

ROGERS, C. R. Significant learning in therapy and in education. Educational leadership, v. 16, n. 4, p. 232-242, 1959.

UNESCO. Os 17 objetivos de desenvolvimento sustentável: objetivo 4. educação de qualidade. Disponível em: <http://www.agenda2030. org.br/ods/4/>. Acesso em: 6 maio. 2019.

YUAN, L. MOOCs and Open Education Timeline. 2015. Disponível em: <http://blogs.cetis.org.uk/cetisli/2015/05/11/moocs-and-open-education-timeline-updated/> . Acesso em: 2 abr. 2019. 
ENSINO HÍBRIDO COMO DESENHO DE CAMINHO ALTERNATIVO PARA A EDUCAÇÃO CONTINUADA NA SAÚDE

Nelson Luís Eufrásio Junior

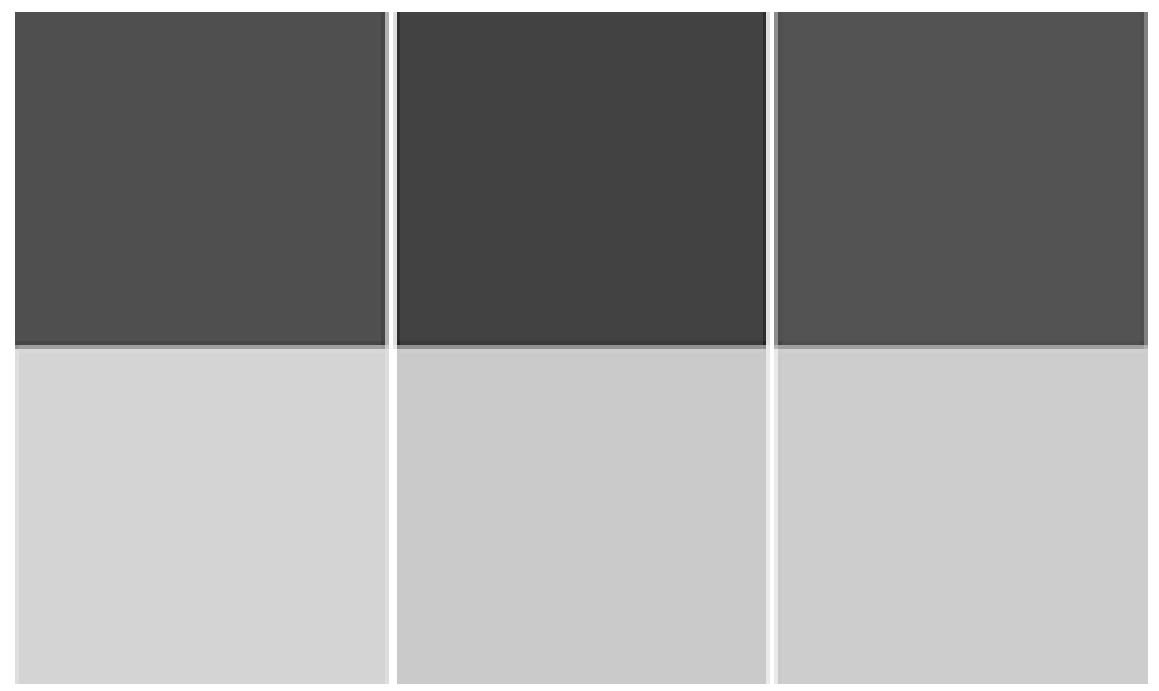




\section{INTRODUÇÃO}

A adoção de diferentes metodologias na educação continuada é uma importante iniciativa. Essa prática nos direciona para um contexto onde a formação inicial e continuada de profissionais possui visibilidade e reconhecimento por parte das instituições. É nesse cenário que pessoas atuam, dia após dia, em suas múltiplas áreas profissionais, dando continuidade aos saberes e às competências desenvolvidos em suas áreas de estudo, sejam essas na educação básica ou superior. A educação continuada viabiliza o surgimento de relações na coletividade entre pessoas, ao mesmo tempo em que emerge a valorização da pessoalidade e diversidade dos sujeitos.

Propiciar a utilização de metodologias inovadoras no contexto da educação continuada na contemporaneidade é, ao mesmo tempo, premissa e desafio. Premissa no sentido de que busca-se o desenvolvimento contínuo de competências, habilidades e atitudes em colaboradores de diferentes áreas profissionais de uma instituição; e desafio no que se refere à evolução constante, seja das metodologias como das tecnologias e dos sujeitos envolvidos nesse processo educacional. $\mathrm{O}$ mesmo acontece com a educação continuada na saúde, pois por meio desta busca-se o desenvolvimento de competências, considerando o contexto da aprendizagem dos colaboradores de uma instituição.

Nesse sentido, esse capítulo tem como objetivo apresentar o processo de criação e desenvolvimento, sob o viés pedagógico, do curso "Atualização em Prevenção e Controle de Infecções", a partir da adoção do Ensino Híbrido, organizado sob a perspectiva da Sala de Aula Invertida em sua realização, para a Irmandade da Santa Casa de Misericórdia de Porto Alegre. Fundamentado a partir da metodologia Design Thinking apresentada inicialmente pelo tripé "inspiração, ideação e prototipagem", a elaboração desse curso possibilitou a utilização de materiais didáticos personalizados, ambiente virtual de aprendizagem exclusivo e espaço para prática pedagógica simulada, considerando sempre a experiência vivenciada pelos colaboradores com o objetivo da aprendizagem significativa no âmbito da educação continuada, aqui vivenciada em um hospital. O resultado desse protótipo resultou em um curso com considerável índice de satisfação, tanto por parte dos colaboradores envolvidos em sua criação e me- 
diação pedagógica quanto pelos participantes cursistas. Tais fatores de sucesso viabilizaram sua inserção no portfólio de ações educacionais na formação inicial e continuada dos colaboradores da enfermagem da Instituição, sob a curadoria do Serviço de Controle de Infecção Hospitalar, facilitando a sensibilização e a adesão de novos profissionais para a importância da correta higienização das mãos.

\section{O Ensino Híbrido}

A utilização de metodologias ativas em estratégias de ensino e aprendizagem na educação continuada torna-se experiência diferenciada para os envolvidos nesse processo. Colaboradores de uma instituição assumem papéis de facilitadores e educandos, além de suas atividades usualmente desenvolvidas, descobrindo que a educação é processual, mediada e até mesmo problematizada na coletividade, entre facilitadores e educandos. A ação pedagógica não fica restrita ao domínio de um conteúdo específico, mas busca-se justamente a amplitude de conhecimentos adquiridos por diferentes sujeitos, aprimorando desse modo seus saberes necessários para a realização de sua prática profissional.

Nesse cenário surge o Ensino Híbrido, também conhecido por blended learning, que nas palavras de Moran (2018) pode ser compreendido como uma sala de aula ampliada, um espaço estendido, que converge a todo o momento e suas múltiplas configurações. Pensar em soluções educacionais que atendam aos diferentes e complexos contextos profissionais na área da saúde é fundamental para o desenvolvimento inicial e continuado dos colaboradores. O compartilhamento de experiências entre os profissionais faz parte da adoção de metodologias ativas no processo de ensino e aprendizagem, em que o colaborador, quando inserido na posição de educando, passa a ser o protagonista de sua evolução, bem como o responsável pelos saberes e habilidades construídos, seja nas relações estabelecidas com seus pares ou com seus colegas na posição de mediadores de conhecimento, devidamente personalizados, em alinhamento com as necessidades evidenciadas pelos colaboradores. Logo, "personalizar significa que as atividades a serem desenvolvidas devem considerar o 
que o aluno está aprendendo, suas necessidades, dificuldades e evolução - ou seja, significa centrar o ensino no aprendiz" (SCHNEIDER, 2015, p. 69). Para melhor compreensão de como pode ocorrer a convergência entre presencial e online, Horn e Staker (2015) apresentam o seguinte esquema gráfico:

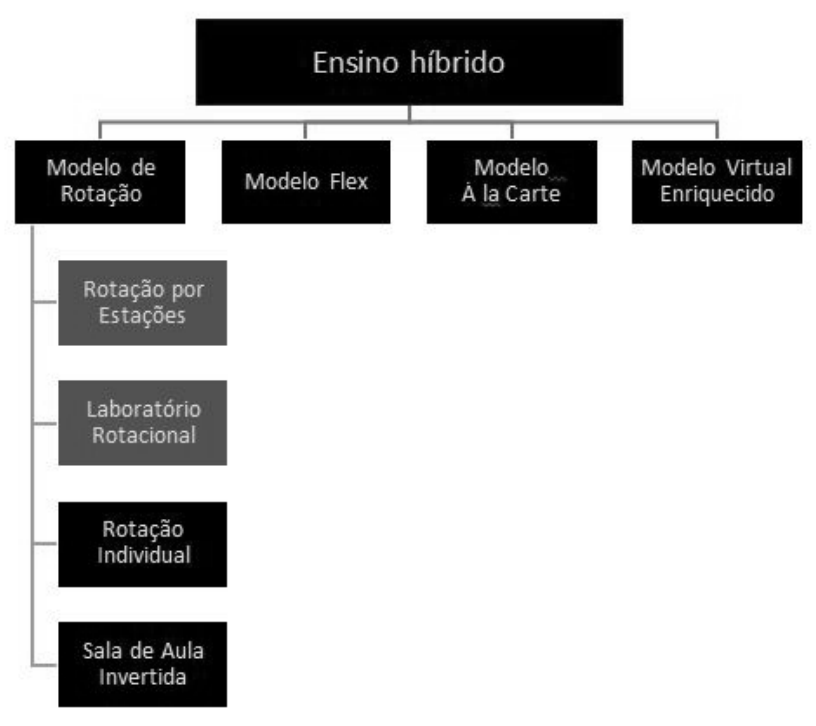

Figura 1: Modelos de Ensino Híbrido

Fonte: Adaptado de Horn e Staker (2015, p. 35)

A experiência de uma abordagem personalizada justifica a necessidade da realização de projetos e atividades em grupos/equipes, do mesmo modo que momentos de individualidade para assimilação e/ou reflexão acerca de conhecimentos adquiridos (HORN e STAKER, 2015). Essas configurações também podem ser vistas como relações híbridas, uma vez que se misturam como dois universos distintos. Assim acontece com o Ensino Híbrido, uma metodologia ativa em que situações distintas convergem, relações se estabelecem em diferentes contextos, espaços ou atividades, sejam físicos(as) ou virtuais. Por esse motivo, para a realização do curso híbrido, será adotado o modelo de Sala de Aula Invertida, pois acredita-se que é o mais adequado à proposta. Ainda de acordo com Horn e Staker (2015), sobre o Ensino Híbrido, podemos destacar: 
Ele é o motor que pode alimentar o ensino personalizado e baseado na competência. Assim como a tecnologia permite a customização de massa em tantos setores para satisfazer as diferentes necessidades de tantas pessoas, o ensino on-line pode permitir que os estudantes aprendam a qualquer momento, em qualquer lugar, em qualquer caminho e em qualquer ritmo, em larga escala. (...) A tecnologia fornece aos estudantes uma forma simples de tomar diferentes caminhos para chegar a um destino comum. Ela pode liberar os professores para que se tornem planejadores, mentores, facilitadores, tutores, avaliadores e orientadores de ensino para chegar a cada estudante de maneiras antes impossíveis. (p. 10 e 11).

Nesse sentido, o Ensino Híbrido é uma potencial oportunidade de mudança, pois possibilita não mais utilizar processos educacionais industriais e fabris. A educação é processual e dinâmica, não pode ser vista como algo estanque, uma vez que a aprendizagem acontece em seu tempo e espaço para cada um dos envolvidos.

\section{CRIAÇÃO DO CURSO}

A proposta para criação e desenvolvimento do curso híbrido "Atualização em Prevenção e Controle de Infecções" surge mediante o contato estabelecido por parte da equipe do SCIH - Serviço de Controle de Infecção Hospitalar. Esse grupo de trabalho contatou a equipe de Educação Corporativa, com a finalidade de desenvolver um curso para atender as necessidades dos profissionais em Enfermagem do complexo hospitalar Santa Casa de Misericórdia de Porto Alegre. Criar cursos para a área da saúde é uma constante na rotina da Educação Corporativa, conduzidos a todo o momento a inúmeros desafios acerca de como proporcionar a melhor mediação pedagógica diante da complexidade de conhecimentos e saberes que as múltiplas áreas hospitalares necessitam.

Nesse momento resgatamos os "três espaços da inovação" (BROWN, 2010) para nossa metodologia de criação de projetos educacionais na educação continuada, sendo são eles a inspiração, a ideação e a prototipagem. Esses três espaços convergem entre si e sua união resulta no Design Thinking, que, segundo Pinheiro e Alt (2012), é utilizado como forma de resumir um modelo de pensamento onde a abordagem de problemas, sejam eles complexos ou 
não, ou seja, o direcionamento de situações em geral ocorre alicerçado em três conceitos primordiais, a empatia, a colaboração e a experimentação. Conceitos esses que possibilitam aos profissionais envolvidos projetar soluções criativas, com foco na experiência significativa a ser vivenciada.

Ao considerarmos o contexto tecnológico em que nos encontramos inseridos na contemporaneidade de nossa sociedade, somos orientados a todo o momento buscar uma atualização em nossos processos, em nossas formações, sempre objetivando a continuidade de nossas carreiras profissionais. Dentro desse pressuposto, era preciso estabelecer um processo de criação interdisciplinar, contando com integrantes de diversas áreas profissionais do hospital, tais como Enfermagem, Pedagogia, Comunicação Social, Programação, entre outras, assim atenderíamos uma das solicitações principais: a de que o curso adotasse efetivamente o uso de tecnologias digitais no processo educacional dos enfermeiros. Na perspectiva de Brown (2010) é possível destacar que:

Em uma equipe multidisciplinar, cada pessoa defende a própria especialidade técnica e o projeto se transforma em uma prolongada negociação entre os membros da equipe, provavelmente resultando em concessões a contragosto. Em uma equipe interdisciplinar, todos se sentem donos das ideias e assumem a responsabilidade por elas. (p.26 e 27)

Ao buscarmos soluções eficazes para um problema efetivo, conscientizamos nossos enfermeiros para a importância da autonomia na aprendizagem, bem como da colaboração e cooperação na construção do conhecimento, haja visto que a mediação pedagógica pode ser considerada como fator contribuinte para o desenvolvimento de metodologias capazes de promover oportunidades que as tecnologias digitais possibilitam nos processos educacionais (SCHLEMMER, 2009).

Ao adotarmos o Design Thinking como metodologia de criação para esse curso, colocamos a experiência a ser vivenciada pelo aluno, em nosso caso o enfermeiro, no centro do processo, como objetivo de nosso planejamento. Proporcionar uma experiência envolvente e significativa a esse enfermeiro é essencial, tendo o objetivo de 
que após a realização do curso todos se sintam motivados a concretizar essas e outras ideias que ocorrem no espaço de aprendizagem híbrido. Por esse motivo, a adoção de uma metodologia de inovação para a construção desse curso torna-se essencial. É preciso evidenciar ao grupo sua importância, seu envolvimento, sua empatia como essencial para o desenrolar do projeto. Compreender a cultura da Enfermagem, dedicar tempo para esses momentos propiciam oportunidades de inovação, de descobrir soluções efetivas e duradouras para a relevância da aprendizagem aqui mediada.

No momento que então efetivamos no grupo de criação a convergência entre os três espaços de inovação, descritos por Brown (2010) como a inspiração, a idealização e a prototipagem, buscamos traduzir para o grande grupo a importância da identificação da sobreposição de critérios para o surgimento de boas ideias, conforme síntese a seguir:

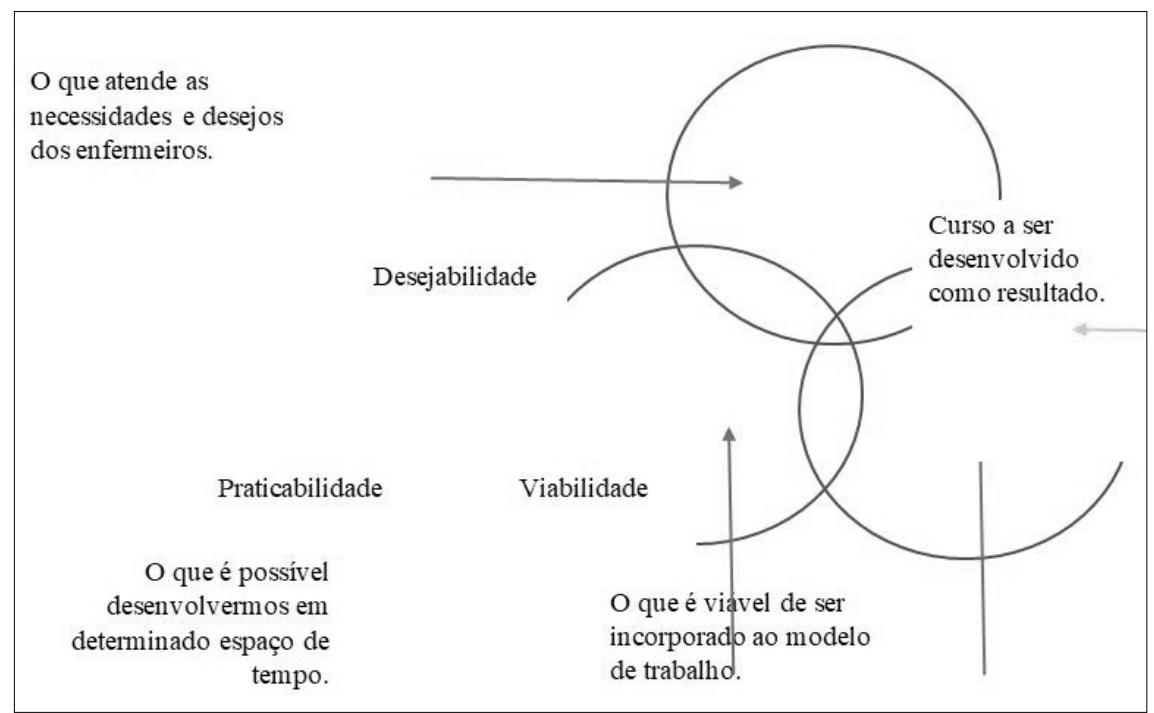

Figura 2: Critérios de sobreposição para boas ideias

Fonte: adaptado de Brown, 2010

De acordo com a imagem anterior, é preciso que ocorra uma convergência entre as ideias consideradas em cada um dos três estágios do processo de design. Segundo Brown (2010), é preciso cogitar o que é desejável e efetivamente faz sentido para as pessoas (desejabilidade), o que pode ser desenvolvido ao ponto de ser parte de um mo- 
delo de negócio (viabilidade) e, por fim, o que poderá ser experimentado para habilitar os envolvido em sua utilização (praticabilidade).

É notório que diferentes fatores podem limitar o protótipo e, consequentemente, a versão final. $\mathrm{O}$ fator tempo, na maior parte dos casos, impacta nos processos de criação, sobretudo em um hospital, onde corre-se contra o tempo a todo o momento, pois lidamos com o resgate e/ou a manutenção de vidas. Nesse sentido, o Design Thinking favorece uma cultura de otimismo em que é preciso acreditar no resultado positivo de ideias e ações. Felizmente, todos os envolvidos no processo de criação desse curso possuíam expectativas promissoras com relação a sua realização. Partindo desse princípio, realizamos alguns encontros para mapeamento de ideias em que desenharam-se as fases de inspiração, ideação e prototipagem, originando a estrutura a seguir:

\begin{tabular}{l|l|l}
\hline \multicolumn{3}{c}{ Curso: Atualização em Prevenção e Controle de Infecções } \\
\hline \multicolumn{2}{c}{ Objetivo do curso: Preparar os enfermeiros para atuar } \\
\multicolumn{1}{c}{ prevenção das IRAS }
\end{tabular}

Quadro 1: Matriz do Protótipo de Curso

Fonte: $\mathrm{O}$ autor

${ }^{1}$ IRAS - Infecções Relacionadas à Assistência à Saúde são aquelas adquiridas pelo paciente no decorrer de período de internação em hospital ou unidade básica de saúde, que não possuíam nenhuma evidência no processo de admissão. Para maiores informações, consulte bibliografia disponibilizada pela ANVISA - Agência Nacional de Vigilância Sanitária em www.anvisa.gov.br. 
O quadro anterior apresenta como se deu o processo de criação do curso híbrido "Atualização em Prevenção e Controle de Infecções", cujo objetivo geral era o de preparar a equipe de enfermagem, em sua totalidade, para atuação eficaz na prevenção de IRAS - Infecções Relacionadas à Assistência em Saúde. No estágio inicial definiu-se que o objeto de inspiração será a ampliação de conhecimentos, por parte da equipe de enfermagem sobre a epidemiologia, bem como a adequação dos processos relacionados. É importante que, especificamente para os facilitadores e multiplicadores do curso, adiciona-se como objetivo a necessidade de formação permanente de sua equipe. Após a fase de ideação, define-se que é necessário desenhar como se dará o processo de ideação, quais momentos serão estabelecidos para a aprendizagem e mediação pedagógica de conhecimentos. Então a equipe envolvida nesse projeto, sabendo que a educação é processual e não-linear definiu que o curso seria estruturado em três momentos que são:

10: Encontro inicial para apresentação do curso e do AVA Moodle, para orientações gerais de como poderá ocorrer o processo de aprendizagem. Esse momento inicial, na fase de realização do protótipo será fundamental, pois é quando a equipe de enfermagem terá contato com a metodologia de Ensino Híbrido, mais precisamente com a sala de aula invertida.

$2^{\circ}$ : Discussão dos protocolos assistenciais e sua aplicação nas atividades de enfermagem, que poderão acontecer no decorrer do curso, independente do espaço, seja esse presencial ou virtual, como forma de exemplificar que a aprendizagem é pertinente em todo o contexto. $3^{\circ}$ : Realização de simulação realística em duplas para exercício prático dos conhecimentos propostos, reflexões acerca dos conhecimentos revisitados e aperfeiçoados nessa atividade de educação continuada, bem como para conclusão fechamento do curso híbrido e seus desdobramentos futuros.

O curso encontra-se estruturado em 12 horas de atividades, sendo 4 horas especificamente para a atividade de simulação realística. As demais 6 horas dedicam-se aos estudos no ambiente virtual de aprendizagem. Essa carga horária de realização do curso pode ser gerenciada pelo colaborador no tempo máximo de 30 dias para a conclusão. A escolha pelo Ensino Híbrido, em especial pela sala de aula invertida como alternativa metodológica para a realização do 
curso deu-se em razão de que, nessa modalidade os conhecimentos teóricos são estudados no ambiente virtual de aprendizagem, com o suporte de materiais didáticos desenvolvidos especialmente para a construção do conhecimento dos colaboradores em saúde; enquanto o espaço da sala de aula será utilizado para discussões, reflexões, resolução de estudos de casos, entre outras atividades. Mattar (2017) destaca:

Dessa maneira, é possível dizer que a sala de aula invertida é uma metodologia ativa, mas que, para se concretizar, precisa, incluir nela própria outra ou outras metodologias ativas; seja como uma metametodologia, ou carregaria, como uma concha ou um caracol, outras metodologias dentro de si. (p. 40).

Em nossa Sala de Aula Invertida teremos um ambiente adicional. Contaremos com um espaço específico para a prática simulada, o Centro de Simulação Realística - CSR. É nesse espaço que realizaremos a atividade final do curso, que consistirá em exercícios de observação e ação acerca de todos os conhecimentos mediados no decorrer do curso. O diferencial proporcionado pelo CSR é ter sido planejado, desde sua construção inicial, como um espaço de exercício prático simulado, contemplando diferentes espaços, desde um consultório médico até uma sala de cirurgia, com todo o equipamento necessário para uma ambientação fiel ao ambiente que o colaborador poderá encontrar nas dependências de nosso complexo hospitalar, bem como de outros hospitais. É importante ressaltar que a existência desse espaço, extremamente importante para a aprendizagem do colaborador, é resultado de parceria entre a Irmandade da Santa Casa de Misericórdia - ISCMPA e a Universidade Federal de Ciências da Saúde de Porto Alegre - UFCSPA. 


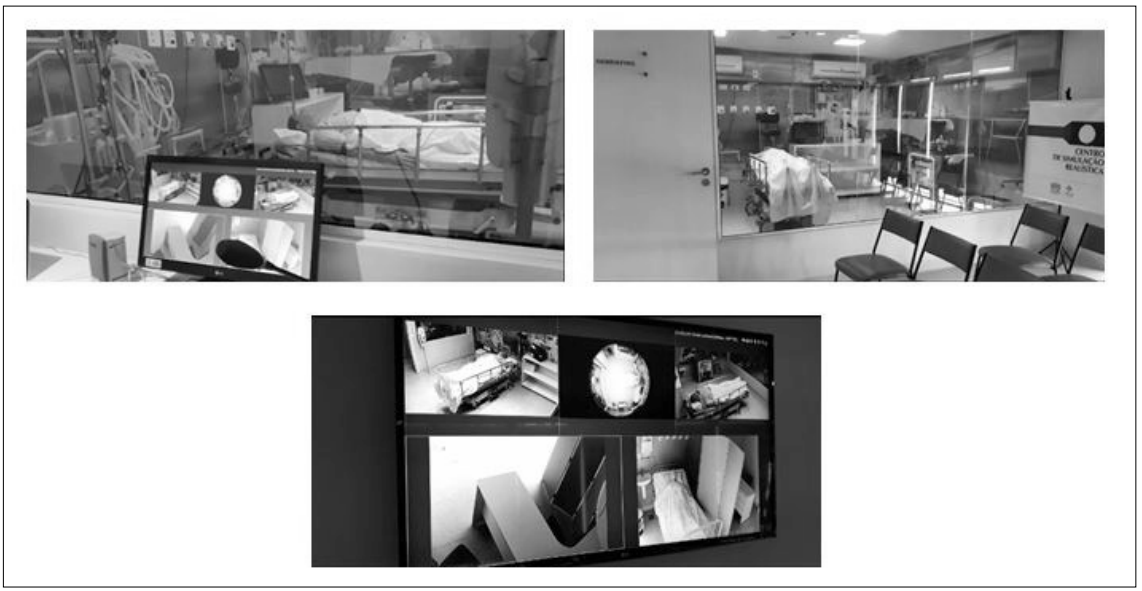

Figura 3: Centro de Simulação Realística Fonte: o autor

Do mesmo modo que o CSR foi desenhado para a realização de atividades práticas, a equipe desenvolvedora desse projeto desenhou a estrutura, em conjunto com o time de Educação Corporativa da Instituição, de como será a apresentação do ambiente virtual de aprendizagem; seus materiais didáticos, que foram desenvolvidos no editor de conteúdos HTML Microsoft Sway, sob a perspectiva de trilhas de aprendizagem; bem como atividades e estudos de casos, criados com o auxílio das ferramentas Hot Potatoes e Google Forms.

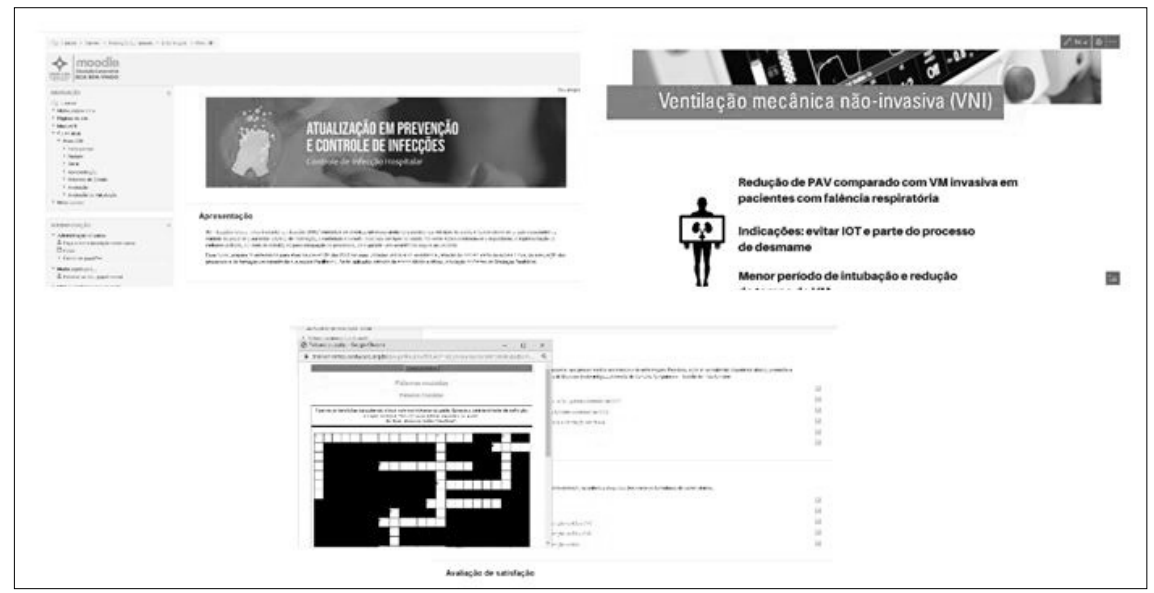

Figura 4: Ambiente Virtual de Aprendizagem e materiais didáticos Fonte: $\mathrm{o}$ autor 


\section{REALIZAÇÃO DO PROTÓTIPO}

O protótipo do curso "Atualização em Prevenção e Controle de Infecções" foi realizado com um grupo reduzido de enfermeiros, para mapeamento dos processos, compreensão das considerações emitidas pelos cursistas e facilitadores. Esse momento é fundamental, pois a instituição não possui registro anterior de ação educacional sob a metodologia do Ensino Híbrido. Outrora, as ações eram realizadas nos formatos de educação presencial ou $100 \% \mathrm{EaD}$ somente.

Foram convidados 12 enfermeiros para participarem do curso. Desses, 10 concluíram o curso, ou seja, participaram ativamente dos momentos de aprendizagem propostos em seu decorrer (sala de aula invertida e simulação realística). $100 \%$ dos concluintes classificaram o conteúdo abordado, os facilitadores e a satisfação geral como ótimo; $90 \%$ apontaram a qualidade da infraestrutura (física e virtual) como ótima. É unânime entre os participantes que o curso seja expandido para todos os enfermeiros da Instituição, mantendo seu formato híbrido por esse viabilizar maior adesão.

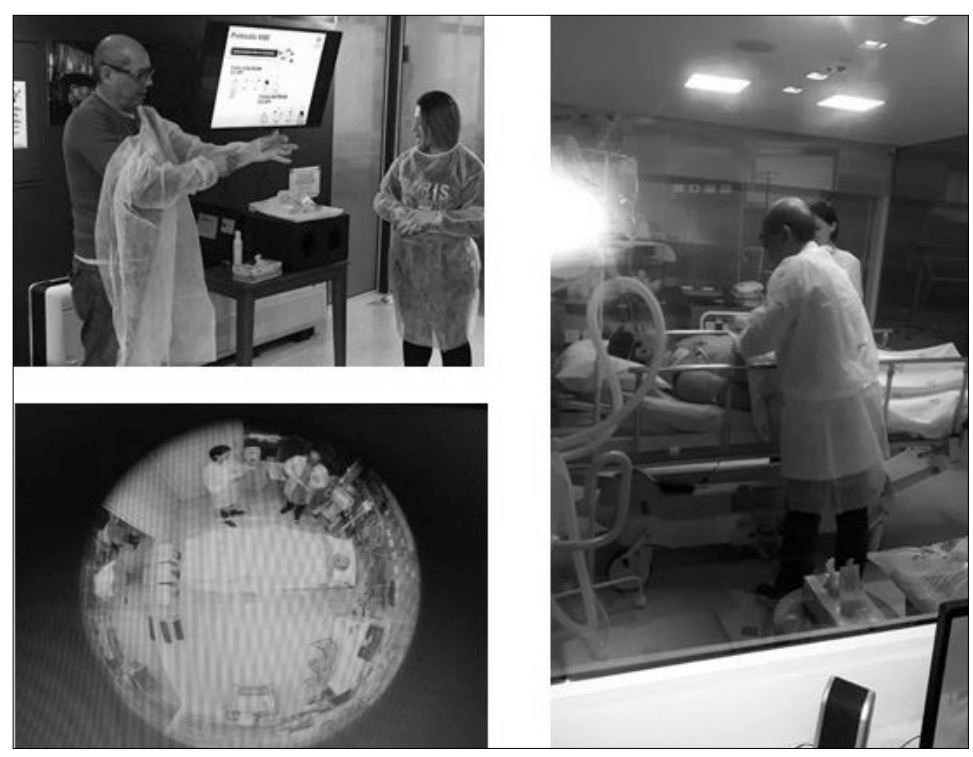

Figura 5: Realização de protótipo

Fonte: $\mathrm{o}$ autor 
Sendo essa a primeira experiência de educação continuada através da modalidade de Ensino Híbrido, sabemos que existe um longo caminho a ser percorrido no que se refere a utilização de metodologias ativas na saúde.

\section{CONCLUSÃO}

A experiência de construir e desenvolver, pedagogicamente, um curso para enfermeiros foi extremamente positiva, no que se refere a confirmação da viabilidade da proposta do Ensino Híbrido como facilitador dos processos de mediação do conhecimento e, principalmente, como fomentador de colaboradores conscientes, participativos e críticos de sua aprendizagem. Após a realização do protótipo, as equipes envolvidas na criação já evidenciam novas possibilidades de cursos e atividades em que desejam implementar metodologias ativas nos processos de educação continuada.

O processo inicial do Design Thinking como suporte para a criação foi uma grata surpresa para a equipe, pois possibilitou a execução de uma metodologia ativa na prática, enquanto era realizado o estudo de aplicabilidade de uma segunda metodologia no protótipo, fato esse que coloca o hospital como espaço de inovação educacional efetivo e, consequentemente, apresentará novos desdobramentos e possibilidades pedagógicas.

\section{REFERÊNCIAS}

MORAN, José. Educação híbrida: um conceito-chave para a educação, hoje. In: BACICH, Lilian. NETO, Adolfo Tanzi. TREVISANI, Fernando de Melo. Ensino Híbrido: personalização e tecnologia na educação. Porto Alegre: Penso, 2015.

BRASIL. Agência Nacional de Vigilância Sanitária. Medidas de prevenção de infecção relacionada à assistência à saúde. Brasília: Anvisa, 2017.

BROWN, Tim. Design Thinking: uma metodologia poderosa para decretar o fim das velhas ideias. Rio de Janeiro: Elsevier, 2011. 
HORN, Michael B. STAKER, Heather. Blended: usando a inovação disruptiva para aprimorar a educação. Porto Alegre: Penso, 2015. MATTAR, João. Metodologias ativas para a educação presencial, blended e a distância. São Paulo: Artesanato Educacional, 2017.

PINHEIRO, Tennyson. ALT, Luis. Design thinking Brasil: empatia, colaboração e experimentação para as pessoas, negócios e sociedade. Rio de Janeiro: Elsevier, 2011.

SCHLEMMER, Eliane. Colaboração e cooperação na educação online: da formação à ação pedagógica em rede utilizando a tecnologia de Metaverso. In: DAMIANI, Magda Floriana. PORTO, Tânia Maria Esperón. SCHLEMMER, Eliane. (Orgs.) Trabalho colaborativo/cooperativo em educação: uma possibilidade para ensinar e aprender. São Leopoldo: Oikos; Brasília: Liber Livro, 2009.

SCHNEIDER, Fernanda. Otimização do espaço escolar por meio do modelo de ensino híbrido. In: BACICH, Lilian. NETO, Adolfo Tanzi. TREVISANI, Fernando de Melo. Ensino Híbrido: personalização e tecnologia na educação. Porto Alegre: Penso, 2015. 


\section{EXPERIÊNCIA EM METODOLOGIAS ATIVAS EM SALA DE AULA NO ENSINO SUPERIOR}

Cristiane Kessler de Oliveira

$$
\text { João Padilha Moreira }
$$

Luiz Leonardo Nascimento Denicol

Querte Teresinha Conzi Mehlecke

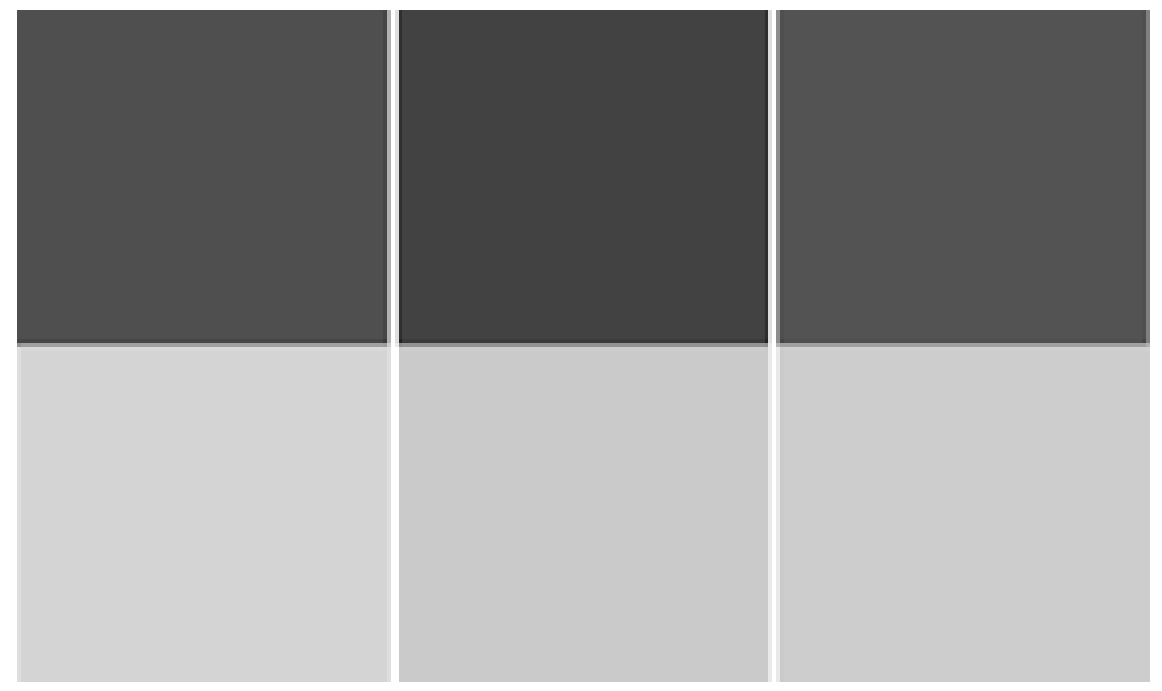




\section{INTRODUÇÃO}

As práticas educacionais vêm sofrendo constantes alterações. Até poucos anos, podia ser considerado um bom docente universitário aquele que tivesse o domínio do conteúdo a ser ministrado. No entanto, muito pouca atenção se dava à forma de transmissão desse conteúdo, o que resultava em aulas muito semelhantes, utilizando quase sempre exclusivamente a metodologia oral de exposição de conteúdos ao discente.

Nos últimos anos, no entanto, a necessidade de novas práticas tem se intensificado. $\mathrm{O}$ rápido avanço das tecnologias e o aumento na quantidade de fontes de informação, bem como a facilidade de acesso a elas, têm ampliado e possibilitado os estudos e práticas de novas metodologias. Mais do que isso, tem demandado essas novas metodologias com certa urgência, tornando-se cada vez mais importante e desafiador manter o interesse do discente no que está sendo realizado em sala de aula.

Esse novo discente, que possui toda essa informação ao alcance da mão, cuja atenção é cada vez mais difícil de obter, desafia as metodologias de ensino ditas tradicionais. Faz-se necessário estimulá-lo e desafiá-lo por meio de novas formas de ensinar, de modo a obter um discente mais engajado no processo de ensino e aprendizagem.

Tendo em vista todo esse cenário, identifica-se essas demandas com o intuito de otimizar o tempo em sala de aula e proporcionar uma aprendizagem mais efetiva voltada à prática para o mercado de trabalho. Sendo assim, a Faculdade Tecnológica FAQI de Gravataí tem capacitado o seu corpo docente para o uso de metodologias ativas em sala de aula.

A Faculdade de Tecnologia de Gravataí - FAQI, instituição comprometida com o aprendizado do discente e com a percepção das mudanças de comportamento provocadas pela ubiquidade da tecnologia e da informação, vem se preocupando cada vez mais com a construção do conhecimento e aprendizagem dos discentes. Para isso, busca nas metodologias ativas uma nova possibilidade de ensino e aprendizagem focados nos discentes. Por isso, tem investido na formação continuada de docentes voltada para as metodologias 
ativas e utilizando uma delas, como a aprendizagem baseada em problemas, para promover um ensino desafiador e com sentido a todos os envolvidos, em especial os docentes e discentes.

No meio social e acadêmico que vivemos, onde o acesso à internet está cada vez mais facilitado e nas mãos da maioria de nossos discentes, há uma integração de espaços e tempos, que faz com que este processo ocorra em uma relação simbiótica e constante entre os mundos físico e digital (MORAN, J., 2015). A educação, portanto, se torna cada vez mais híbrida, utilizando múltiplos espaços que vão além da sala de aula.

Conforme afirma Berbel (2011),

O engajamento do aluno em relação a novas aprendizagens, pela compreensão, pela escolha e pelo interesse, é condição essencial para ampliar suas possibilidades de exercitar a liberdade e a autonomia na tomada de decisões em diferentes momentos do processo que vivencia, preparando-se para o exercício profissional futuro (BERBEL, 2011, p. 29).

O discente, ao sentir-se parte importante do processo de ensino e aprendizagem, tende a contribuir mais ativamente com o processo, propondo novos temas e materiais a serem analisados e discutidos, o que pode impactar positivamente na sua vida acadêmica e profissional.

Além disso, o fato de sentir-se desafiado favorece ainda mais o engajamento deste discente no processo, o que possibilita que a aprendizagem ocorra de forma mais natural e definitiva.

Dessa forma, percebe-se a importância da formação continuada para os docentes, uma vez que com a conectividade nas mãos dos discentes, se faz necessário a busca por metodologias que atendam esse público que chega na academia com a tecnologia na palma da mão.

Os alunos de hoje crescem com acesso à Internet, YouTube, Facebook, MySpace e a muitos outros recursos digitais. Em geral, podem ser vistos fazendo os exercícios de matemática enquanto enviam mensagens de texto, postam e curtem no Facebook e ouvem música, tudo ao mesmo tempo. Muitos desses estudantes relatam que quando chegam à escola precisam se desconectar e emburrecer, já que as escolas proíbem telefones celulares, iPods e quaisquer outros dispositivos digitais (Bergmann e Sams, 2016). 
Assim posto, apresenta-se o relato de experiência com o intuito de conhecer as tecnologias e a aprendizagem baseada em problemas como metodologias utilizadas pelos docentes a partir da qualificação ofertada pela instituição.

\section{APORTE TEÓRICO}

Como aporte teórico para este estudo, buscamos em Moore e Kearsley (2013); Bacich, Neto e Trevisani (2015); Moran(2015); Araújo e Sastre(2009); Honer e Staker(2015) e demais colaboradores, conceitos de metodologias ativas, aprendizagem baseada em problemas, aprendizagem baseada em competências, ensino híbrido e as tecnologias digitais.

Partindo destes conceitos, observa-se que o ensinar e aprender, a partir das metodologias ativas, requer o repensar no fazer pedagógico, nos recursos e mídias. Fazer um "mix", um híbrido entre o presencial e o virtual, utilizando as diferentes mídias, poderá tornar as aulas mais significativas, atrativas, dinâmicas e com mais sentido para o discente. Esse "mix" pode propiciar uma aprendizagem mais fascinante pela oportunidade de "hibridizar" o ensino através do uso de diferentes recursos.

A utilização destas tecnologias pode impactar significativamente, também, no profissional que os cursos superiores estão formando. Uma vez que buscamos estudantes, e portanto futuros profissionais, proativos, é importante propor e utilizar metodologias de ensino e aprendizagem que proporcionem o envolvimento do discente, e em que estes precisem decidir, com autonomia, como os resultados serão avaliados, num processo de construção e desconstrução, que os leve ao saber (MORAN, 2015).

Segundo Bacich, Neto e Trevisani (2015), "o ensino é híbrido porque todos somos aprendizes e mestres, consumidores e produtores de informação e de conhecimento" (p.29). De acordo com os autores, em pouco tempo passamos de grandes consumidores das mídias para "prosumidores", quer dizer, consumidores e produtores de diversas mídias.

Por outra via, o modelo de educação que utiliza um "blended", a mistura do ensino presencial com o virtual, tem se popula- 
rizado no ensino superior por possibilitar que a educação avance os limites da sala de aula, utilizando a tecnologia como desejarem (MOORE; KEARSLEY, 2013).

Neste sentido, as metodologias ativas de ensino aprendizagem vem ganhando cada vez mais espaço, especialmente quando o professor está em sala de aula trabalhando uma dinâmica que provoca o aluno, desacomoda e o faz pensar. Dessa forma, o professor está também contribuindo para que o aluno esteja engajado no mercado de trabalho, que utiliza cada vez mais diferentes dinâmicas para a seleção de pessoas, por exemplo.

Percebe-se que o nosso discente chega na faculdade, segundo Munhoz (2015), com presença conectada, ele está conectado e o docente também. Colaborando, Oliveira e Gaspar in Mehlecke (2017, p.101), nos dizem que "há um apoio explícito na ubiquidade das conexões em rede entre as pessoas, os artefatos digitais e os conteúdos". Neste sentido, $a$ ubiquidade se refere ao ato de tornar o uso dos recursos tecnológicos como o computador, de forma simples e natural que as pessoas nem percebam sua presença, mesmo quando os utilizam, tal como aconteceu com outras tecnologias, como a escrita e a eletricidade, absolutamente incorporadas em nossas vidas (JUNIOR, 2017).

Ainda, a aprendizagem baseada em problemas - ABP, uma das metodologias ativas trabalhadas na formação docente, é a atualização docente pois, segundo Araújo e Sastre (2009), a ABP "também requer que o docente atualize seus conhecimentos, visto que os alunos exigem sua supervisão rigorosa e respostas às perguntas sobre novas teorias que encontram na internet ou àquelas sobre um possível estudo que venha realizar"(p.19). Deste modo, é fundamental qualificar os docentes para o uso desta metodologia ativa, pois, o docente quando qualificado, buscará as melhores formas de ensinar a partir da $A B P$.

O foco das metodologias ativas estão centradas no discente e a aprendizagem baseada na competência - $\mathrm{ABC}$, "implica aspectos de perseverança e determinação, porque os estudantes, a fim de progredir, têm de trabalhar até que estes sejam resolvidos com sucesso; eles não podem simplesmente esperar até que a unidade termine."(HORN; STAKER, p.9, 2015). 
Diante desses conceitos, a FAQI está construindo uma nova concepção para o ensino a partir das metodologias ativas as quais atendem aos objetivos e metas institucionais e não somente de curso.

\section{METODOLOGIA}

Uma vez demarcado o universo do estudo, que são os professores dos cursos superiores de Tecnologia em Processos Gerenciais e Análise e Desenvolvimento de Sistemas da FAQI Gravataí, identificou-se como metodologia adequada o estudo de caso, uma vez que o objetivo do estudo era analisar que metodologias de ensino estão sendo utilizadas na docência do ensino superior. Sendo assim, um questionário semiaberto, o qual articula as dimensões quantitativa e qualitativa, foi aplicado ao total de professores de ambos os cursos.

Segundo Yin (1994, p. 18),

os estudos de caso são a estratégia preferida quando questões "como" e "porquê" estão a ser colocadas, quando o investigador tem pouco controlo sobre os acontecimentos, e quando o foco está nos fenômenos contemporâneos dentro do contexto da vida real.

O autor também afirma que "[...] o estudo de caso é uma investigação empírica que investiga um fenômeno contemporâneo em profundidade e em seu contexto de vida real, especialmente quando os limites entre o fenômeno e o contexto não são claramente evidentes" (Yin, 2010, p.38).

Este estudo buscou, através de uma pesquisa aplicada a todos os docentes dos Cursos Superiores de Tecnologia da FAQI, Gravataí, RS, verificar se e como as metodologias ativas são utilizadas em sala de aula nos cursos superiores de Tecnologia em Processos Gerenciais e Tecnologia em Análise e Desenvolvimento de Sistemas. Esta pesquisa partiu de um questionário semiaberto, o qual é caracterizado por perguntas que devem ser respondidas pelos sujeitos da pesquisa. Segundo Barros e Lehfeld (2007), o questionário é o instrumento mais utilizado para a coleta de dados, o qual ainda pode ser aberto ou fechado. 
A partir do conceito de Yin, Barros e Lehfeld, esta pesquisa busca conhecer as metodologias utilizadas em sala de aula pelos docentes da FAQI. Para isso, foi inicialmente desenvolvido e, posteriormente aplicado um questionário a um grupo de 15 docentes dos Cursos Superiores de Tecnologia em Processos Gerenciais e Tecnologia em Análise e Desenvolvimento de Sistemas da Faculdade de Tecnologia de Gravataí, FAQI. O grupo representa o número total de docentes destes cursos na instituição. O questionário semiaberto possibilitou aos participantes assinalar as opções como também justificar as respostas. Os resultados da pesquisa foram organizados em gráficos e análise das respostas discursivas.

\section{ANÁLISE DE DADOS}

A análise do instrumento, questionário, aplicado aos 15 professores dos Cursos Superiores de Tecnologia em Processos Gerenciais e Análise e Desenvolvimento de Sistemas partiu da metodologia quali-quantitativa. O número corresponde à totalidade dos docentes destes cursos.

A análise qualitativa tomou como base as respostas descritivas e a quantitativa completou a análise a partir das respostas das questões fechadas, no intuito de compreender melhor a forma como as metodologias são utilizadas em sala de aula e as razões para essa utilização. Com o uso de análise quali-quantitativa, buscou-se compreender se e como os docentes utilizam as metodologias ativas em sala de aula, bem como a sua compreensão a respeito desses conceitos.

Partindo dos critérios qualitativos, a pesquisa identificou o perfil do docente que $66,7 \%$ dos pesquisados, têm até dez anos de magistério no ensino superior. Quando perguntados a respeito do uso de recursos tecnológicos em sala de aula, 100\% respondeu que utiliza algum recurso tecnológico em sala de aula. O mais apontado, utilizado por $100 \%$ dos entrevistados, foi o vídeo, seguido pela apresentação em Power Point ou Similar, indicado por 86,7\%; e Moodle e internet, ambos apontados por $80 \%$ dos sujeitos pesquisados.

Quanto a resposta dos docentes sobre a frequência de utilização dos recursos tecnológicos como metodologia ativa em sala de aula, todos responderam entre "sempre" e "frequentemente". 
Ao serem questionados a respeito dos motivos pelos quais consideram importante a utilização de recursos tecnológicos em sala de aula para a aprendizagem dos alunos, um dos professores pesquisados respondeu: "as tecnologias estão nas mãos dos alunos e precisamos utilizá-las em favor da aprendizagem". Isso reflete o interesse do docente em aproveitar o fascínio que as novas tecnologias provocam nos estudantes, bem como seus anseios pelo novo, e utilizá-los para aumentar a atenção e o foco também no assunto da sala de aula.

Nas palavras do professor entrevistado também podemos identificar o interesse em utilizar metodologias ativas de ensino e aprendizagem que despertem a atenção do aluno e que proporcionem uma interação maior deste com o objeto de ensino. Também podemos identificar o foco no aluno, o que é uma das principais características das metodologias ativas de ensino aprendizagem.

Neste sentido, as palavras de outro professor pesquisado complementam: "com a série de recursos tecnológicos disponíveis aos alunos fora da sala de aula, é impossível despertar seu interesse sem que em algum momento haja uma interação com esses recursos em sala de aula". Tal consideração refere a consciência do professor a respeito do uso das tecnologias conectivas de modo a colocar o aluno no centro do processo de ensino aprendizagem, onde a aprendizagem acontece em contexto de rede (OLIVEIRA e GASPAR in MEHLECKE, 2017, p. 101). Por outra via, Moran (2015, p.16) afirma que "o que a tecnologia traz hoje é integração de todos os espaços e tempos".

Em um outro momento, ao serem questionados se consideram que a utilização de recursos tecnológicos em sala de aula seria uma metodologia ativa de aprendizagem, os professores pesquisados, de um modo geral, demonstram conhecimento a respeito do tema, na medida em que respondem, por exemplo, que, para que seja uma metodologia ativa "tem que haver participação do aluno. O simples fato de utilizar um recurso de apresentação do conteúdo não significa que está envolvendo o aluno no processo.". Dessa forma, o professor demonstra o entendimento de que, para que seja efetivamente uma metodologia ativa, há que se desacomodar o aluno, trazê-lo para o centro, fazê-lo parte atuante desse processo.

Outro professor pesquisado responde que a utilização que faz dos recursos em sala de aula seria sim uma metodologia ativa, "pois 
Metodologia ativa de aprendizagem é um processo amplo e possui como principal característica a inserção do aluno/estudante como agente principal responsável pela sua aprendizagem, comprometendo-se com seu aprendizado".

Em uma outra questão, sobre as capacitações para utilização de metodologias ativas em sala de aula, $66,7 \%$ dos professores dizem ter sido capacitados para isso. Isso se deve ao investimento da instituição em preparar os seus docentes para essas metodologias.

Na FAQI, o corpo docente, juntamente com a coordenação dos cursos, reúne-se sistematicamente para discutir as práticas de ensino e o seu impacto na formação do discente. Estas práticas, a partir das metodologias ativas, estão baseadas também na $\mathrm{ABP}$ ou PBL - Problem Based Learning (Aprendizagem Baseada em Problemas), as quais aparecem como um caminho favorável à proposta curricular para os cursos, em que o corpo docente está sempre atualizado com as demandas de mercado, evidenciando através de visitas técnicas, estudo de casos e desenvolvimento e criação de novos casos empresariais, utilizando-se e socializando as experiências dos docentes e discentes. E com base nas diretrizes curriculares do catálogo nacional de curso tecnológicos, preparando os discentes baseado nas metodologias ativas.

Os Projetos Pedagógicos dos cursos da FAQI baseiam-se na premissa do levantamento contínuo das competências a serem trabalhadas em sala de aula. Esta opção de Projeto Pedagógico impacta sobre a instituição, docentes e discentes, apresentando novas características. Os discentes assumem o papel ativo e de colaboração na tarefa de gestão, pois contribui nas avaliações internas e no planejamento. $\mathrm{O}$ aprendizado contextual funde-se na base da experiência, e os projetos interdisciplinares tornam-se mais claros, produzindo uma visão sistêmica do curso e da sociedade.

Neste processo de aprendizagem a avaliação não é mais de controle e sim orientada a critérios de aprendizagem. Para os docentes o seu papel nesta proposta é ser orientador, mediador e incentivador da formação do discente com as características definidas no perfil do profissional do mercado, com competências e habilidades muito explícitas e múltiplas para a sociedade. 


\section{CONCLUSÃO}

Pensar em metodologia ativa é pensar no discente como centro do processo de ensino e aprendizagem, e no docente como motivador deste processo. Nessa perspectiva, a reflexão dos docentes sobre o uso da metodologia ativa em sala de aula é um momento necessário e fundamental. O docente só poderá saber se haverá resultado positivo se experimentar, após planejar, aplicar e avaliar os resultados da aplicabilidade de tecnologias como metodologia ativa.

Para evidenciar e também avaliar o processo, cabe ao docente registrar as experiências do uso das metodologias utilizadas e seus benefícios pedagógicos.

Neste sentido, após analisar o instrumento de pesquisa sobre o uso dos recursos tecnológicos em sala de aula como metodologia ativa, percebe-se que o potencial pedagógico no uso destas ferramentas motivam a aprendizagem. Tais evidências aparecem nas pesquisas quando os docentes relatam o uso de vídeos como fator importante e motivador das aulas. E, o uso das tecnologias em sala de aula propiciam o uso de outras metodologias como a aprendizagem baseada em problemas, a aprendizagem por competências, o ensino híbrido e a aprendizagem ubíqua. Esse conjunto de ações realizadas na FAQI demonstram, nos resultados de avaliações, que as metodologias ativas contribuem fortemente para a construção da aprendizagem e o perfil do egresso dos cursos.

Ao acompanhar o posicionamento dos atores diante das iniciativas de modificação das práxis das metodologias ativas, percebe-se que estamos trilhando por caminhos que nos levam ao novo, novo pensar e novo fazer pedagógico. $\mathrm{O}$ docente conhece a validade e a importância da utilização eficiente e eficaz das metodologias ativas e os encara como desafios e novas possibilidades de inovar. Para isso, os docentes da FAQI refletem sobre a aprendizagem permitindo uma viabilização de resultados em aulas que podem ser mais criativas e atraentes ao discentes. Neste cenário, o uso das tecnologias e de outros recursos em sala de aula na FAQI, não é novidade. O que foi apresentado neste estudo, foi o uso dela como metodologia ativa, o uso como recurso, como parte das aulas trazendo sentido aos discen- 
tes e criando uma rede de possibilidades de metodologias a partir do uso das tecnologias.

Considera-se, portanto, que o uso de diferentes metodologias ativas em sala de aula é visível através da mudança de postura de nosso discente. Quando utilizamos um vídeo, um aplicativo ou mesmo uma pesquisa na internet, um case para reflexão, um problema a ser resolvido, uma visita técnica, a aula se torna mais atrativa, mas elas por si só, não farão a diferença, a diferença está na metodologia, nos objetivos traçados para alcançar as competências do curso e da disciplina. Sugere-se estudos futuros, como forma de complementar o presente, visando a verificação, sob a ótica do discente, do impacto dessas tecnologias e das metodologias ativas no processo de ensino e aprendizagem.

\section{REFERENCIAS}

ARAÚJO, E. Ulisses; SASTRE, Genoveva. Aprendizagem baseada em problemas no ensino superior. 2. ed. São Paulo : Summus, 2009.

BACICH, Lilian; NETO, Adolfo Tanzi; TRVISANI, Fernando de Mello (organizadores). Ensino híbrido: personalização e tecnologia na educação. Porto Alegre : Penso, 2015.

BARROS, Aidil Jesus da Silveira; LEHFELD, Neide Aparecida de Souza. Fundamentos da metodologia científica. 3. ed. São Paulo, Pearson, 2007.

BERBEL, Neusi Aparecida Navas. As metodologias ativas e a promoção da autonomia de estudantes. Semina: Ciências Sociais e Humanas, Londrina, v.32, n. 1, p. 25-40, jan./jun. 2011.

BERGMANN, J.; SAMS, A. Sala de aula invertida: uma metodologia ativa de aprendizagem. Rio de Janeiro: LTC, 2016.

HORN, Michael B.; STAKER, Heather. Blended: usando a inovação disruptiva para aprimorar a educação. Porto Alegre : Penso, 2015.

JUNIOR Peter Jandl. Ubiquidade e Transparência Computing, Ubiquity and Transparency. UniAnchieta Computação. Disponível em: http://www.portal.anchieta.br/revistas-e-livros/ubiquidade/pdf/artigo8.pdf> Acesso em: 30 de março de 2017. 
MEHLECKE, Querte T. C. et al. Educação a distância no ensino superior: teoria e prática. In: MEHLECKE, Querte T. C. (Org.).São Paulo: Opção Livros, 2017. Série EaD em debate, v. 2.

MOORE, M. KEARSLEY, G. Educação a distância. 3. ed. São Paulo: Cengage Learning, 2013.

MORAN, J. Mudando a educação com metodologias ativas. [Coleção Mídias Contemporâneas. Convergências Midiáticas, Educação e Cidadania: aproximações jovens. Vol. II] Carlos Alberto de Souza e Ofelia Elisa Torres Morales (orgs.). PG: Foca Foto-PROEX/UEPG, 2015. Disponível em: < http://www2.eca.usp.br/moran/wp-content/uploads/2013/12/ mudando_moran.pdf> Acesso em: 20 mar. 2017.

Yin, R. K. Pesquisa estudo de caso: desenho e métodos. 2 ed. Porto Alegre: Bookman, 1994.

Estudo de caso: planejamento e métodos. 4. ed. Porto Alegre: Bookman, 2010. 


\section{ABORDAGENS HÍBRIDAS NA EaD: O PIBID COMO ESTRATÉGIA DE PERMANÊNCIA PARA OS ALUNOS DA LICENCIATURA EM MATEMÁTICA}

Kátia Cilene da Silva -

Luiza Helena Félix de Andrade Ulisses de Melo Furtado

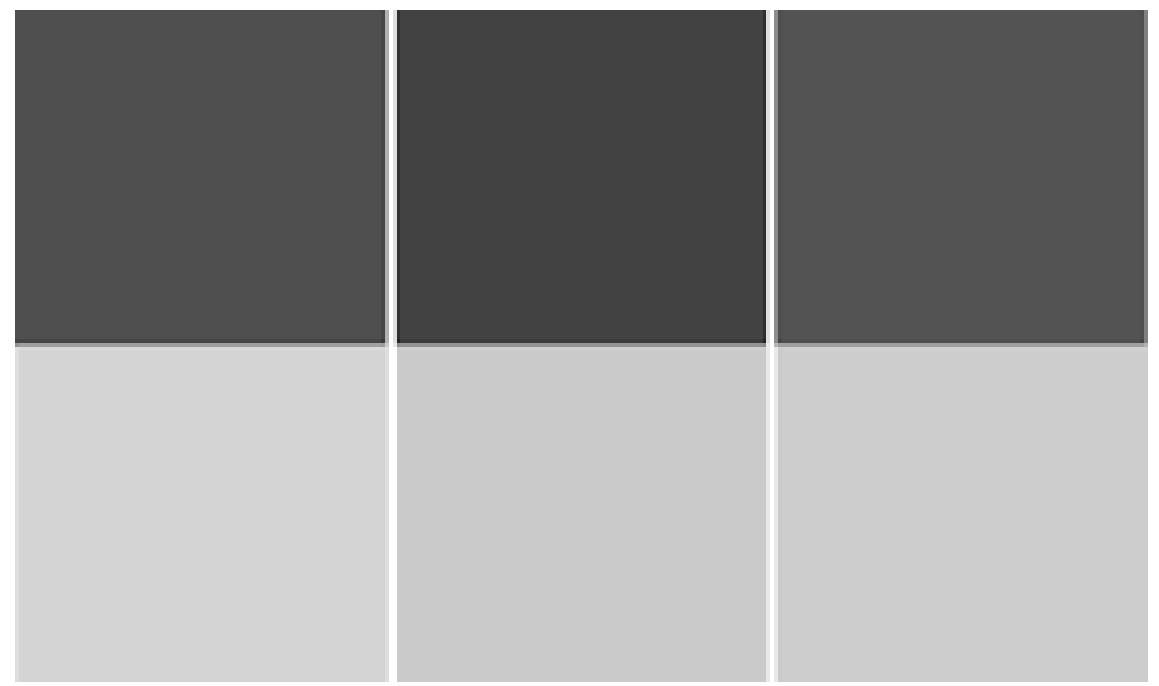




\section{INTRODUÇÃO}

O Programa Institucional de Bolsas de Iniciação à Docência (PIBID) tem como um de seus objetivos principais o incentivo à formação de docentes em nível superior para a educação básica, assim como, elevar a qualidade da formação inicial de professores nos cursos de licenciatura, promovendo a integração entre educação superior e educação básica e uma relação entre teoria e prática, como elemento fundamental para uma boa formação.

De acordo com o Censo da Educação Superior-2016, apesar do número de alunos matriculados em cursos de licenciatura ter aumentados nos últimos anos, esse número ainda é minoria dentre os alunos matriculados nesse nível de ensino. De todos os alunos matriculados em cursos de licenciatura no Brasil, $42,1 \%$ estão na modalidade a distância, ou seja, uma grande parte da formação de futuros professores se dá através dessa modalidade de ensino. O Sistema Universidade Aberta do Brasil (UAB), instituído para "o desenvolvimento da modalidade de educação a distância, com a finalidade de expandir e interiorizar a oferta de cursos e programas de educação superior no País", vem, desde sua criação, colaborando como um dos responsáveis pela formação de professores para a educação básica, uma vez que, de acordo ainda com dados do Censo da educação superior-2016, a maior parte dos alunos matriculados no ensino superior na modalidade a distância é formada por alunos de licenciatura. Onde essa formação de professores para rede básica através do sistema UAB, se dá, principalmente, fora dos grandes centros.

Nesse contexto educacional surgem diversas estratégias para potencializar os índices de permanência e a conclusão de curso pelos alunos dos cursos a distância. No caso específico das licenciaturas a distância surge, em 2010, o PIBID, cujo relato de experiência da inclusão de alunos de cursos de licenciatura a distância será apresentado neste artigo.

\section{O PIBID COMO ABORDAGEM HÍBRIDA PARA ALUNOS DA EAD}

É nesse contexto que se inserem os subprojetos de matemática EaD que foram desenvolvidos entre 2011 e 2013 em Escolas da Rede Pública Estadual do Rio Grande do Norte atendidas pela UFERSA, 
utilizando métodos híbridos para potencializar a permanência dos alunos de cursos a distância, através do engajamento destes em atividades presencial do PIBID. Por meio destes subprojetos, os professores-alunos da licenciatura em matemática foram inseridos em uma pesquisa de intervenção didática por meio da participação no Projeto Político Pedagógico das escolas desenvolvendo atividades de extensão integradas ao ensino da didática de conteúdos matemáticos com a utilização de jogos construídos com material concreto, jogos digitais e objetos de aprendizagem.

Assim, o espaço da escola pública foi o campo de experiência desses licenciando para a sua construção/constituição como educadores matemáticos durante o curso de graduação, fortalecendo o vínculo da universidade com a sociedade.

Os objetivos instrucionais de ambos os projetos tiveram como foco desenvolver ações acadêmicas da Licenciatura em Matemática a Distância da UFERSA, por meio da integração do ensino, pesquisa e extensão articulando ações da formação docente com a educação básica do sistema público, relacionando-as com as disciplinas de práticas e ensino.

Tais objetivos for alcançados a partir do estabelecimento de parcerias com escolas da rede pública buscando melhorar a qualidade do ensino de Matemática na educação básica a partir da integração de jogos digitais o objetos de aprendizagem nas práticas adotadas pelos docentes; através das quais valorizou-se mais o magistério, incentivando os professores da área de Matemática a participarem de práticas inovadoras no processo de ensino-aprendizagem. Esta participação se deu com a elaboração e desenvolvimento de experiências práticas que contribuíram para a melhoria da qualidade do ensino de matemática nas escolas parceiras. Com isso o espaço da escola pública como campo de experiência para a construção do conhecimento na formação de professores de matemática para a educação básica no uso de novas tecnologias foi valorizado e proporcionou-se aos professores de Matemática a participação em ações, experiências metodológicas e práticas docentes inovadoras, articuladas com a realidade da escola e da região do semiárido.

As atividades para o ensino-aprendizagem de Matemática nas escolas públicas foi dividido em quatro fases: a) Fase I - Forma- 
ção dos professores-alunos para o trabalho na didática de conteúdos matemáticos usando jogos construídos com material concreto, jogos digitais e objetos de aprendizagem; b) Fase II - Diagnóstico e análise a priori da situação de ensino-aprendizagem de matemática nas escolas antes da implementação dos projetos; c) Fase III - Intervenção nas escolas; e, d) Fase IV - Diagnóstico e análise a posteriori da situação de ensino-aprendizagem de matemática nas escolas com a implantação dos projetos.

Durante a realizados dos projetos nas escolas foram realizados estudos sobre a legislação vigente, os documentos norteadores (PCNs) e os projetos pedagógicos das escolas. Foram utilizados recursos de intervenção/interação como a etnografia, a realização de grupos focais e de entrevistas e, ainda, a aplicação de questionários de coleta de dados e de testagens com os alunos das escolas.

A avaliação das atividades realizadas pelos diversos atores dos projetos foi co-participativa, formativa e processual, envolvendo os gestores e professores das escolas, os coordenadores de área e os supervisores dos projetos, visando não a avaliação do sujeito, mas a avaliação dos impactos da implantação dos projetos nas escolas. Também foi incluída no processo avaliativo a autoavaliação de bolsistas de iniciação à docência, supervisores e coordenadores de área. Para cada etapa de avaliação foram elaborados instrumentos adequados às atividades realizadas e o registro das atividades/percepções dos atores envolvidos foi realizado através de relatórios parciais e finais, conforme solicitado pelas coordenações de área.

\section{ANÁLISE E DISCUSSÃO DE RESULTADOS}

Durante o levantamento de dados sobre o PIBID foi possível identificar que, no ano de 2013 - ano de realização dos subprojeto dos quais se trata o presente estudo, estavam em execução 2996 subprojetos, nas mais diversas áreas do conhecimento e regiões do país, dos quais somente 300 (aproximadamente 10\%) eram da área de matemática, aplicados à diferentes níveis de ensino, a saber: a) Ensino Infantil - 2\%; b) Ensinos Infantil e Fundamental - 1,3\%; c) Ensinos Infantil, Fundamental e Médio - 0,6\%; d) Ensinos Infantil e Médio 
- 0,6\%; e) Ensino Fundamental - 20,5\%; f) Ensinos Fundamental e Médio - 35\%; e, g) Ensino Médio - 40\% (CAPES, 2019).

Relatos de experiência como o de Cavalcante (2013) e Silva e Costa (2016) apresentam importantes resultados sobre diferentes subprojetos do Pibid, ambos com Licenciandos de Matemática.

Do ponto de vista quantitativo, a partir dos dados referentes a evasão, apresentados no censo da educação superior (INEP, 2017), temos que em 2014, na licenciatura em matemática, essa taxa chegou a $52,6 \%$, sendo que, em 2010, era de apenas 12,8\%. Esse percentual não difere ensino presencial e a distância, sendo representativo das duas modalidades de ensino. Quando consultados os dados da Coordenação de Aperfeiçoamento de Pessoal do Ensino Superior (CAPES), sobre a pesquisa com estudantes dos cursos ofertados pela UAB, o índice de desistência dos alunos chega a 17,7\% (CAPES, 2017), considerando evadidos e trancados, porém esses dados se referem a todos os cursos e não somente a Licenciatura em Matemática. Sobre taxa de conclusão da licenciatura em matemática, verificou-se que essa taxa tem aumentado nos últimos anos, pois, segundo o censo (INEP, 2017), passou de 2,4\%, em 2010, para 24,2\%, em 2014. Em relação a taxa de permanência nos cursos de licenciatura em Matemática essa taxa diminuiu consideravelmente nos últimos anos, pois passou de 84,8\%, em 2010, para 23,3\%, em 2014 (INEP, 2017).

Analisamos os dados separando os alunos da licenciatura em matemática da $\mathrm{EaD}$ em dois grupos. Um dos grupos é formado pelos alunos que participaram do PIBID e o outro grupo formado pelos alunos que não participaram do PIBID. Dentro desses dois grupos estudamos alguns índices que nos ajudaram na interpretação dos resultados.

Examinamos os dados de desistência (evasão), concluídos e ativos. Deixando claro que o grupo de desistentes é formado pelos alunos que trancaram e não retornaram e, ainda, pelos alunos que abandonaram o curso. Os índices do grupo dos alunos que participaram do PIBID (21,8\% conclusão e $20 \%$ permanência) são superiores aos índices do outro grupo ( $8,43 \%$ conclusão e $5,90 \%$ permanência) no que se refere à conclusão e permanência no curso, sendo menores no que se refere à evasão (58,18\% pibidianos e $85,65 \%$ não pibidianos).

Chegamos à conclusão que a taxa de desistência da licenciatura em matemática da UFERSA na modalidade a distância é muito alta, 
mas quando analisamos dentre os participantes do PIBID, essa taxa diminui em quase $30 \%$, ficando próximo ao nível da taxa de desistência nacional. Conseguimos ver também, que a taxa de conclusão dentre os alunos que participaram do PIBID é quase três vezes maior do que a dos alunos que não participaram do PIBID. E por fim, a permanência é maior também dentre os alunos do PIBID.

Levando em consideração a pesquisa realizada pelo sistema UAB (CAPES, 2017), a maioria dos estudantes que desistiram alegaram, como principal fator, a dificuldade de conciliar estudo e trabalho $(40,7 \%)$, sendo que em segundo lugar, foram citados fatores como organização do tempo (26,9\%) e distância do polo $(21,6 \%)$.

Já ao serem analisados os dados coletados com os egressos, participantes dos dois subprojetos do PIBID, pode-se perceber que, destes, $67 \%$ estão atuando como docentes da educação básica e $23 \%$ não. Dos $67 \%$ que estão atuando como professores, $75 \%$ atuam em na rede pública de educação básica e $25 \%$ na rede privada.

Dentre os egressos que estão atuando como professores da educação básica, 75\% atuam no Ensino Fundamental II e 25\% no Ensino Médio. Todos eles atuam em disciplinas da área de Ensino de Ciências e Matemática, porém somente $50 \%$ ministrando a disciplina de matemática, dentre os demais 25\% ministram a disciplina e Ciências para as séries iniciais do Ensino Fundamental II e 25\% ministram a disciplina de Física para as séries finais do Ensino Fundamental II.

No que se refere ao tipo de vínculo desses docentes com as institucionais de ensino nas quais atuam, foi possível identificar uma diversidade de tipos de vínculos, sendo que somente $60 \%$ são contratados, $20 \%$ são substitutos e $20 \%$ bolsistas.

Quanto a formação e capacitação dos pibidianos após a conclusão do curso de Licenciatura em Matemática EaD, observou-se que cerca de $83 \%$ deles continuou se qualificando após a conclusão do curso. Aproximadamente $67 \%$ cursaram especialização, sendo $75 \%$ destes na área de matemática e $25 \%$ fora da área. Dentre os que cursaram especialização, $50 \%$ também cursaram aperfeiçoamento. Dentre os que não cursaram especialização, 50\% cursaram aperfeiçoamento.

Analisando-se os dados coletados no grupo focal, verificou-se que todos os participantes estão atuando na área. Participaram do 
grupo focal tanto pibidianos, quanto supervisores.

Os relatos dos pibidianos nos falam sobre a importância que a participação no projeto teve para a sua formação como docentes, bem como o estímulo a continuar se capacitando. Também aparecem relatos que confirmam o estímulo à produção científica, como pode ser percebido na seguinte fala:

$<$ PIBIDIANO X> Hoje eu vejo o PIBID como uma porta de entrada para a minha carreira como pesquisadora. Todo o caminho que eu venho percorrendo hoje, através da pesquisa, eu remeto, primeiramente, a oportunidade de ter participado do PIBID. Ele me proporcionou a experiência de sala de aula, mas também a oportunidade de ser pesquisador, de elaborar artigos científicos, participar de eventos... Eu acho que o aluno da EaD que não participou do PIBID não tem a mesma vivência e a mesma visão da graduação comparado aos que participaram.

Os relatos de casos de sucesso se repetem em, praticamente, todas as falas do pibidianos, merecendo destaque para dois casos: a) o de uma pibidiana que hoje é professora da rede e atua como supervisora em um novo subprojeto do PIBID; b) o de uma pibidiana que hoje atua como Assistente a Docência da CAPES, no polo onde cursou sua licenciatura.

Há relatos, também, de alunos que entraram no PIBID já no seu primeiro semestre de graduação, sendo esta a primeira participação em um projeto. Relatam que foi uma experiência nova, que proporcionou uma nova visão sobre a matemática, inclusive incluindo a perspectiva de realização de pesquisas na área.

A pibidiana que atua como supervisora atualmente ressaltou a importância de conseguir se colocar no lugar do pibidiano, pois já foi uma, conforme relato a seguir:

$<$ PIBIDIANO Y> Uso a minha experiência como pibidiana para orientar os novos pibidianos na atuação do subprojeto. Agora tenho uma visão diferente do que quando era pibidiana. Uso o laboratório de matemática, com materiais concretos, que foi montado na primeira edição do PIBID na universidade. Como supervisora, percebo agora a influência do PIBID até no comportamento dos alunos na minha sala de aula do ensino fundamental. Percebo que a presença dos pibidianos está influenciando positivamente os alunos. 
Já na perspectiva dos supervisores o destaque é para a oportunidade que as escolas tiveram de participar de um projeto desse tipo, bem como para a turma de alunos que participou do projeto, devido à possibilidade de novos aprendizados, pois conseguiram perceber os resultados com os pibidianos e com os alunos de matemática das escolas.

Um dos supervisores, que hoje atua como preceptor em um subprojeto do Programa de Residência Pedagógica, destaca

$<$ SUPERVIDOR Z> Eram 10 pibidianos. O PIBID na escola foi um projeto que permitiu aplicar a matemática na prática, com material concreto, saindo da teoria. Chegamos a ir a Pernambuquinho para calcular o avanço das dunas sobre as casas da orla. Criamos um xadrez gigante no pátio da escola e uma sala foi adaptada para ser o laboratório de matemática, que a escola não tinha antes... Saiu da teoria e foi para a prática”.

Os relatos apresentados corroboram os dados quantitativos e demonstram o diferencial de qualidade que o programa trouxe para o curso a distância em questão, especialmente para os alunos que participaram dos subprojetos que são objeto do presente estudo.

\section{CONSIDERAÇÕES FINAIS}

Para os alunos da UFERSA, considera-se ter alcançado como resultado e consequente contribuição do PIBID, a preparação dos alunos bolsistas para a carreira docente na área de matemática em escolas públicas, bem como para a realização de pesquisas científicas sobre a prática docente em educação matemática e para a sua atuação em projetos de extensão. Já para o Curso de Licenciatura em Matemática a Distância da UFERSA, o projeto propiciou a articulação do curso com as escolas e a comunidade, contribuiu para a consolidação da proposta de formação de Licenciados em Matemática, para a melhoria da qualidade do estágio supervisionado da licenciatura nas escolas da rede pública, para a diminuição da evasão e para o aumento da valorização do magistério entre os alunos do curso.

Para os professores das escolas parceiras, foram realizadas ações de formação continuada de todos professores das escolas parceiras 
que atuaram como supervisores. $\mathrm{O}$ projeto também contribuiu para a melhoria na qualidade do trabalho desses docentes, para a melhoria da qualidade do ensino na área de matemática e para a valorização do professor da rede pública de educação básica enquanto profissional da educação. Já para os alunos das escolas parceiras, constatou-se a melhoria da qualidade da aprendizagem, bem como para o aumento do interesse destes pela disciplina de matemática, assim como o estímulo para o ingresso na universidade pública. Enquanto que para as escolas parceiras, contatou-se a contribuição para a melhoria na qualidade do ensino na escola e para o aumento da qualidade do ensino e aprendizagem na área de matemática, bem como para o aumento da frequência das atividades experimentais na escola.

Como contribuições que contemplaram todos os atores envolvidos nos projetos, considera-se a publicação dos resultados em anais de congressos e periódicos das áreas de educação matemática e tecnologias educacionais e a divulgação de resultados e projetos em eventos locais, regionais e nacionais.

Concluímos assim, que o PIBID não tem somente uma importância na melhoria da formação inicial e continuada dos professores da rede pública de educação básica, mas também é um agente importante na redução da evasão dos alunos nos cursos de licenciatura, bem como estímulo para conclusão do curso, no contexto da educação a distância.

Como continuação do trabalho que foi realizado de 2011 a 2013, aprovamos novamente PIBID no ano de 2018, cujo subprojeto está sendo desenvolvido também com alunos da Licenciatura em Matemática EaD, inclusive com uma das escolas participantes do subprojeto anterior. Como um trabalho futuro, queremos fazer a mesma análise com esse grupo de pibidianos do projeto atual e comparar as duas experiências.

\section{REFERÊNCIAS}

CAPES. Resultado da pesquisa com estudantes do Sistema UAB. Brasília: CAPES, 2017. Fonte: Fundação CAPES Ministério da Educação: http://www.capes.gov.br/uab/resultados-da-pesquisa-com-os-estudantes-do-sistema-uab 
CAPES. (28 de abril de 2019). PIBID. Fonte: Fundação CAPES Ministério da Educação: http://www.capes.gov.br/educacao-basica/capespibid/relatorios-e-dados

CAVALCANTE, J. L. Clube de matemática e a formação docente: contribuições do Pibid. In: CASTRO, P. A.(org.). Desafios e perpectivas na profissionalização docente - Pibid/UEPB. Vol. 1. Campina Grande: eduepb, 2013. p. 55-66.

INEP. (31 de agosto de 2017). Censo da Educação Superior-2016. Fonte: portal.inep.gov.br: http://portal.inep.gov.br/artigo/-/asset_ publisher/B4AQV9zFY7Bv/content/mec-e-inep-divulgam-dados-do-censo-da-educacao-superior-2016/21206

SILVA, K. C.; COSTA, M. N. D.. O uso de jogos digitais como objetos de aprendizagem no ensino da matemática: uma proposta para as escolas públicas do semiárido potiguar. In: RAABE, A. L. A.; GOMES, A. S.; BITTENCOURT, I. I.; PONTUAL, T.. Educação criativa: multiplicando experiências para a aprendizagem (Série professor criativo, IV). Recife: Pipa Comunicação, 2016. pp. 374-409. 


\section{O USO DA METODOLOGIA HÍBRIDA COMO POSSIBILIDADE DIDÁTICA MOTIVADORA DE APRENDIZAGEM NA EDUCAÇÃO BÁSICA}

Antônio Soares de Oliveira Filho Kátia Cilene da Silva

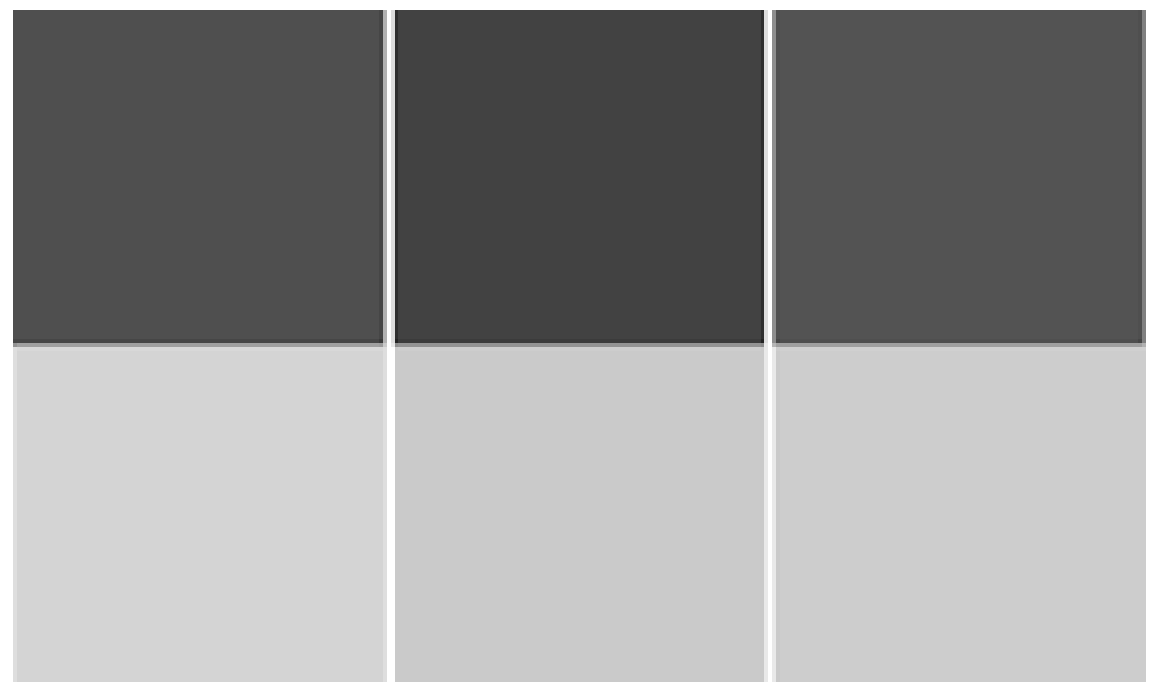




\section{INTRODUÇÃO}

O mundo contemporâneo está sem sombra de dúvidas, sendo marcado por profundas e constantes transformações, em várias dimensões da vida humana.

E nesta perspectiva de mudanças e desafios é necessário o docente reavaliar sua prática dentro deste contexto. Não é mais novidade para ninguém a tecnologia está aí em todos os contextos sócio culturais, sendo usadas de todas as formas. Mas a pergunta é: estamos usando-as de forma correta, e em particular os alunos usam-na para fins de aprendizagem? E os docentes? Seguem a mesma lógica? Esses e outros questionamentos permeiam nosso pensar.

Percebe-se que os desafios estão postos para todos educadores dentro deste contexto global na qual estamos inseridos. Somos atingidos de todas as direções com informações que atinge a sociedade de forma direta ou indiretamente, com uma velocidade tremenda, crianças, adolescente, adultos, todos, ou seja, configurando assim uma sociedade tecnológica.

Dissertando Libâneo (1998, p.15) "o mundo contemporâneo [...] está marcado pelos avanços na comunicação e na informação e por outras tantas transformações tecnológicas e científicas".

É relevante salientar que todo docente precisa ter consciência que a vida é uma caminhada de aprendizagens.

José Moran (2015, p.11) diz que "é possível ensinar e aprender de muitas formas..." e "...a educação é um processo de profunda interação humana...” (Moran, 2015, p.35). O autor afirma também que:

Os alunos gostam de um professor (a) que os surpreenda, que traga novidades, que varie suas técnicas e seus métodos de organizar o processo de ensino-aprendizagem (MORAN, 2015, p.35)

Percebe-se que os dias atuais evidenciar uma variedade de recursos e cursos online de forma exponencial e possibilita a capacitação profissional de todos aqueles que buscam novos aprendizados e crescimento na sua área profissional e educacional.

Dentre essa variedade de recursos que o contexto tecnológico nos proporciona, a metodologia híbrida, evidencia como uma grande possibilidade de aprendizagem em vários níveis da educação. É 
relevante destacar também que a metodologia híbrida é um tipo de metodologia ativa. Mas o que venha a ser metodologia ativa?

\section{METODOLOGIAS ATIVAS DE APRENDIZAGEM}

A expressão Metodologias Ativas de Aprendizagem já é um objeto de estudo de grande interesse por parte de estudiosos em várias áreas de conhecimento. Percebe-se sua utilização de forma bem simplória. É necessário um conhecimento desta nova forma de ensinar e aprender. Precisamos sair da zona de conforte e nos aventurar com os pés no chão. Por exemplo: de certa forma já utilizamos essa forma de conhecimento, quando aplicamos uma atividade para resolução de problema, ou as chamadas férias de ciências, são formas de metodologias ativas.

Delineando alguns conceitos sobre essa temática, é oportuno trazermos a lembrança um provérbio chinês em destaque, a saber: "O que eu ouço, eu esqueço; o que eu vejo, eu lembro; o que eu faço, eu compreendo". Esse pensamento foi expressado pelo filósofo chinês Confúcio, e sem dúvida tem uma relação bem direta com a aprendizagem.

Para Silberman (1996) fez uma paráfrase com esse provérbio para nos proporcionar um melhor entendimento quantos aos métodos ativos de aprendizagem expressando a seguinte redação:

Para Dantas e Oliveira (2017) diz:

A expressão Metodologias Ativas de Aprendizagem pode parecer novidade para o professor que atua no campo da EPT. Mas, pelo menos em suas formas mais simples, os professores conhecem meios de ensinar e aprender que podem ser considerados como um tipo de metodologia ativa, ainda que não sejam rotuladas ou conhecidas por essa expressão. $\mathrm{O}$ ensino por meio de projetos, assim como o ensino por meio da solução de problemas, são exemplos típicos de metodologias ativas de aprendizagem. (Dantas e Oliveira, 2017, p. 2).

O processo educacional está passando por grandes mudanças, isso não é mais novidade. É realidade! Mas a questão é! Estamos acompanhando essas mudanças, ou melhor, estamos nos motivando para nos adequar as novas mudanças? São muitos questionamentos, que estão nos provocando uma profunda reflexão na nossa vida diária e princi- 
palmente em nossa prática em sala de aula. Precisamos ter medo do futuro? Acho que não! Se for para nos proporcionar resultados positivos em várias dimensões do saber humano e em particular no processo de aprendizagem dos alunos e na prática do docente que venha mudanças.

Dissertando Moran (2015, p.11) diz:

O avanço do mundo digital traz inúmeras possibilidades, ao mesmo tempo em que deixa perplexas as instituições sobre o manter, o que alterar, o que adotar. Não há respostas simples. É possível ensinar e aprender de muitas formas, inclusive da forma convencional. Há também muitas novidades, que são reciclagens de técnicas digitais se traduz em resultados muito expressivos. (Moran, 2015, p.11).

É preciso desenvolvermos um novo olhar, para esse momento que estamos vivenciando, observando as múltiplas possibilidades didáticas para motivarmos nossos alunos e nossa prática em sala de aula. É sem dúvida uma necessidade urgente para todos aqueles que se envolve na nobre arte do educar, ou seja, no processo de ensino aprendizagem.

Moran (2015, p.31) corrobora que,

As tecnologias digitais facilitam a pesquisa, a comunicação e a divulgação em rede. Temos as tecnologias mais organizadas, como os ambientes virtuais de aprendizagem - a exemplo do Moodle e semelhantes -, que permitem que tenhamos certo controle de quem acessa o ambiente e do que é preciso fazer em cada etapa de curso (Moran, 2016, p.31).

Todo docente que almeja desenvolver com excelência sua prática pedagógica na seara educacional, e em particular em sala de aula. Ele é convocado é ter pleno conhecimento destes termos bem claro, bem entendido na sua mente e prática docente. Vamos destacar alguns termos relevantes para o bom entendimento do docente em sua prática.

\section{ENSINO HÍBRIDO}

Antes de adentrar na discussão em si, faz-se necessário definir o que venha a ser hibridismo. Para o dicionário online de língua portuguesa, hibridismo (genética) característica do cru- 
zamento em que os progenitores se distinguem por dois caracteres, isto é, dois pares de alelos. Característica daquilo que provém de naturezas distintas.

Compreende-se que o termo ensino híbrido é o uso de métodos de ensino presencial e a distância, de forma integrados, ou seja, estabelecendo atividades bem ajustadas e em forma de roteiro dentro do processo de ensino aprendizagem dinâmica. É perceptível que as aulas se tornam flexíveis e dinâmicas, mas é relevante afirmar que tudo acompanhadas por um tutor bem presente, "presente" online.

O ensino híbrido também chamado de blended learning, o método alterna momentos em que o aluno estuda sozinho - em geral em ambiente virtual - e em grupo, quando interage com seus colegas e o professor. Há diversas maneiras de adotar o ensino híbrido. Um recurso que vem sendo bastante usado é a rotação. $\mathrm{O}$ docente divide a sala de aula em várias estações com atividades diferentes, mas que se complementam. É relevante afirmarmos que uma delas pelo menos usa de plataforma digital.

Com o uso de vídeo-aula, os alunos podem aprender por meio de qualquer dispositivo com acesso à internet. Laptops, tablets ou smartphones que pode possibilitar, de certa forma a mesma qualidade do curso e possibilitam o aprendizado dos estudantes de maneira flexível e dinâmica.

No universo corporativo, o ensino a distância se tornou um grande aliado, possibilitando o treinamento e a capacitação dos colaboradores de forma mais dinâmica, prática e com custo reduzido. Todos esses recursos são extremamente enriquecedores dentro do processo de aprendizagem destes educandos, proporcionando interação, dinamismo e a aprendizagem. Precisamos enveredar por essas práticas pedagógicas.

\section{METODOLOGIA}

O trabalho foi realizado na escola Estadual Manoel João, localizada no bairro alto de são Manoel - Mossoró - Rn, tendo como público-alvo docentes do Ensino Fundamental II e discentes de $7^{\circ} ; 8^{\circ}$ ao $9^{\circ}$ anos do Ensino Fundamental II. Com o objetivo de observar se com a utilização da plataforma google classroom ou google sala de 
aula, e das videoaulas postas no ambiente, o que haviam adquirido de conhecimento de acordo com propostas inseridas.

O período de pesquisa iniciou-se no começo do ano letivo de 2019, na referida escola, e o objeto de estudo concentraram-se em três turmas todas pelo turno vespertino. Para coleta de dados foram aplicados dois questionários um para professores 15 professores e outros para 25 anos alunos, de perguntas sobre as possibilidades didáticas motivadoras para o ensino na Educação básica: as tecnologias digitais para os docentes e outro questionário para discentes com seis questões sobre o uso de vídeo aula como possibilidade didática motivadora de aprendizagem na educação básica.

Inicialmente foi feito todo um cadastramento dos alunos para a plataforma google sala de aula e depois os mesmos foram orientados para interagirem no ambiente da plataforma, ambos no início acharam estranho por incrível que pareça, mas aos poucos com orientação foram se acostumando e começaram a interagir um pouco mais. Quanto às produções das vídeo aulas, a maioria foi produzida pelo autor deste artigo e outras quando achava importante inseri-la na plataforma. Na medida em que ia desdobrando-se os conteúdos em sala de aula presencial, orientava-os há também a termos aulas virtuais para reforçarmos o conteúdo ministrado em sala de aula presencial, alguns tiveram dificuldades de interagir por vários motivos: dentre eles podemos citar: timidez, e essencialmente falta de habilidade com essa nova realidade metodológica etc.

Essa metodologia foi aplicada fundamentada conforme afirma Santos (2011): "método é um caminho a ser trilhado pelos pesquisadores na busca do conhecimento. Corroborando também diz Gil (2008),contemplamos a pesquisa de campo através de questionários para investigarmos a realidade que a temática nos proporciona para atingir um fim.

\section{RESULTADOS E DISCUSSÃO}

De acordo com a análise dos dados da pesquisa, percebeu-se que através dos questionários aplicados, foram detectadas as concepções dos docentes e alunos através da estratégia de ensino trabalhada 
em sala de aula: o google sala de aula e a utilização das videoaulas, no que tange ao processo de ensino aprendizagem dos alunos e da prática pedagógica dos docentes.

No gráfico 1, pode-se observar que $66,7 \%$ dos sujeitos já assistiram alguma vídeo aula, percentual este que contempla cerca de $2 / 3$ dos sujeitos da pesquisa.

VOCÊ JÁ ASSISTIU ALGUMA VÍDEO-AULA?

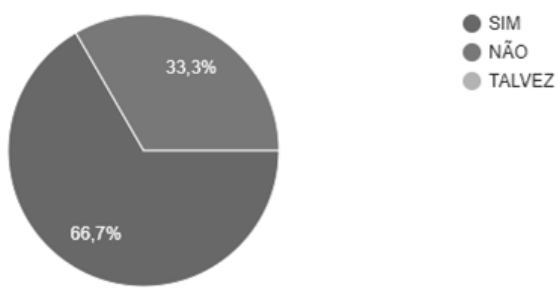

Gráfico 1 - Você já assistiu alguma vídeo aula?

Fonte: Elaborado pelos autores (2019)

Já quando questionados sobre a importância da criação e aplicação de vídeo aulas, percebe-se que nenhum afirmou não ser importante, sendo que 93,8\% responderam sim e apenas 6,2\% talvez, como pode ser observado no gráfico 2 .

COM AS VÍDEO - AULAS VOCÊ ACHA QUE OS ALUNOS APRENDEM?

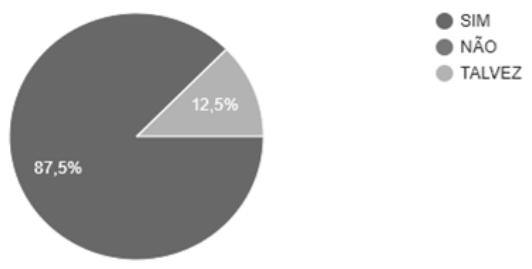

Gráfico 2 - Você acha que é importante usar vídeo aulas?

Fonte: Elaborado pelos autores (2019)

Quando questionados sobre a sua percepção a respeito da aprendizagem dos alunos com o uso de vídeo aula $87,5 \%$ respon- 
deram que os alunos aprendem com vídeo aulas, $12,5 \%$ responderam talvez e nenhum respondeu não, como pode ser observado no gráfico 3 .

VOCÊ ACHA QUE É IMPORTANTE A CRIAÇÃO E APLICAÇÃO DE VIIDEO-AULA?

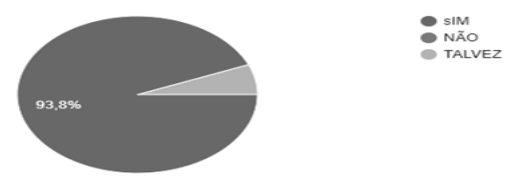

Gráfico 3 - Você acha que os alunos aprendem com vídeo aulas? Fonte: Elaborado pelos autores (2019)

Para corroborar a disseminação desse recurso didático no ensino presencial, dentro e fora da escola, foi perguntado aos sujeitos se já estudaram algum assunto com vídeo aulas; destes $81,3 \%$ disseram já ter estudado com vídeo aulas e somente $18,7 \%$ disseram que não tiveram essa experiência, como pode ser observado no gráfico 4 .

VOCÊ ESTUDOU ALGUM ASSUNTO COM AS VÍDEO- AULAS?

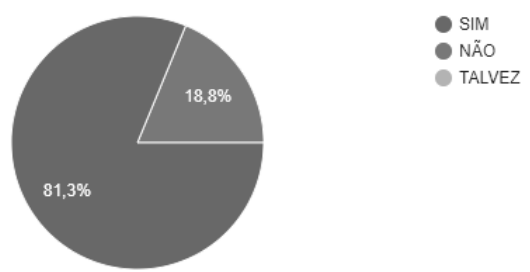

Gráfico 4 - Você estudou algum assunto com vídeo aulas?

Fonte: Elaborado pelos autores (2019)

Todos esses gráficos foram elaborados com os resultados da coleta de dados realizada com cerca de 25 alunos da escola Estadual Manoel João, em 2019, no turno vespertino. 
Quanto ao levantamento de dados realizados com os docentes, foram aplicados a 15 docentes da escola, tratando da temática "possibilidades didáticas motivadoras para o ensino na Educação básica: As tecnologias digitais - Recursos tecnológicos para educadores entusiastas".

Quando perguntados sobre se conhecem as metodologias ativas, cerca de $2 / 3(66,7 \%)$ dos professores disseram conhecer, em contraponto a $1 / 3(33,3 \%)$ dos professores que disseram não conhecer, como pode ser observado no gráfico 5 .

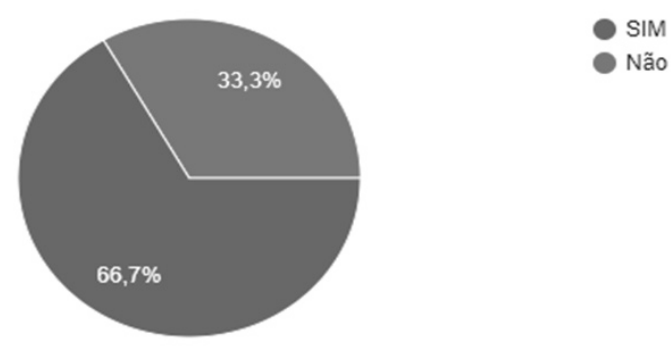

Gráfico 5 - Você conhece as metodologias ativas?

Fonte: Elaborado pelos autores (2019)

Quando questionados sobre o seu conhecimento sobre ensino híbrido, o percentual caiu para $63,6 \%$ que afirmaram conhecer e $36,4 \%$ que disseram não conhecer (Gráfico 6).

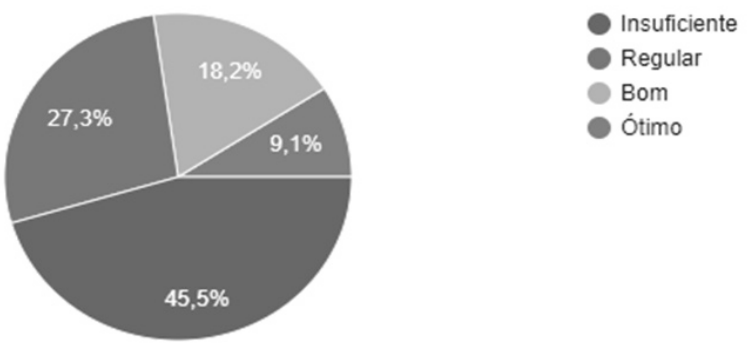

Gráfico 6 - Você tem algum conhecimento sobre ensino híbrido?

Fonte: Elaborado pelos autores (2019)

Quando questionados sobre o uso de metodologias variadas em sua prática pedagógica, os 90,9\% dos professores afirmaram va- 
riar as metodologias utilizadas, enquanto que 9,1\% afirmam que não variam.

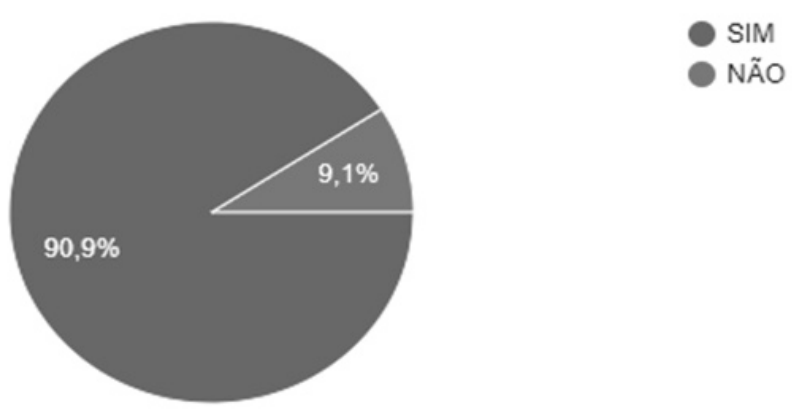

Gráfico 7 - Na sua prática pedagógica costuma variar com o uso das metodologias? Fonte: Elaborado pelos autores (2019)

Apesar de afirmarem variar o uso de metodologias em suas aulas, quando questionados sobre os recursos tecnológicos que utilizam durante as aulas os professores, em sua maioria, afirmam utilizar datashow (36,4\%) e power point (18,2\%), contemplando 54,65\% dos docentes (Gráfico 8).
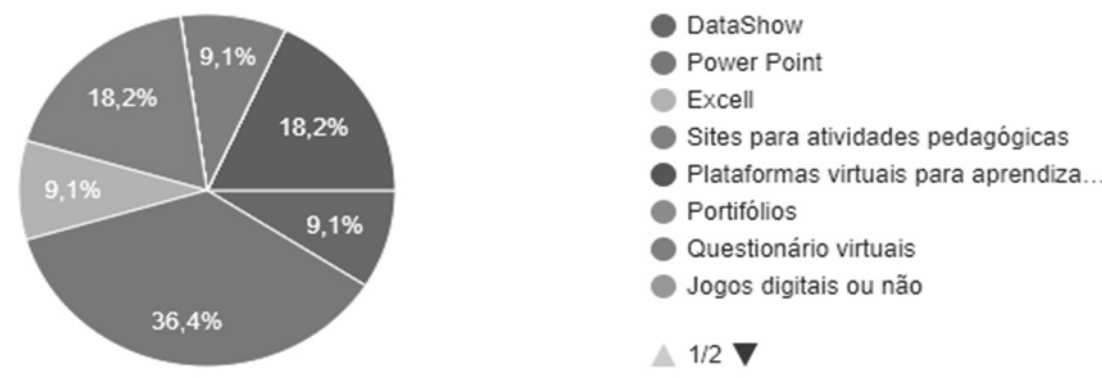

Gráfico 8 - Indique quais os recursos tecnológicos que você costuma utilizar no planejamento e durante a ministração de suas aulas Fonte: Elaborado pelos autores (2019)

Também é possível observar que recursos como "jogos digitais ou não" e "plataformas virtuais de aprendizagem" sequer são citadas. 
Quando questionados sobre os recursos tecnológicos disponíveis na escola os professores a disponibilização de datashow, Power Point, Excel e Plataformas virtuais de aprendizagem, apesar de não serem citadas como utilizadas. Já quando questionados sobre o uso de computadores para a preparação das aulas $10 \%$ dos professores não responderam. Dos 90\% que responderam todos afirmaram utilizar esse recurso para a preparação de suas aulas. Em relação ao incentivo para o uso de TICs, 72,8\% dizem que o incentivo é insuficiente ou regular, o que pode estar influenciando diretamente na prática docente (Gráfico 9).

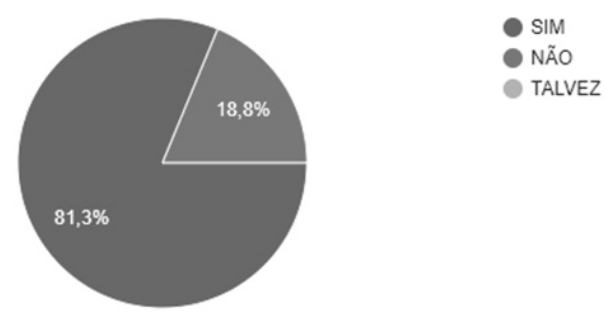

Gráfico 9 - A escola como um todo dá incentivo para o uso de TICs Fonte: Elaborado pelos autores (2019)

Outro aspecto que pode estar influenciando a prática docente é a percepção dos professores sobre a importância do uso da TICs para a aprendizagem dos conteúdos pelos alunos. Como pode ser observado no gráfico 10 , pode-se observar que somente $27,3 \%$ dos professores consideram indispensável, enquanto que $72,7 \%$ consideram com certa relevância.
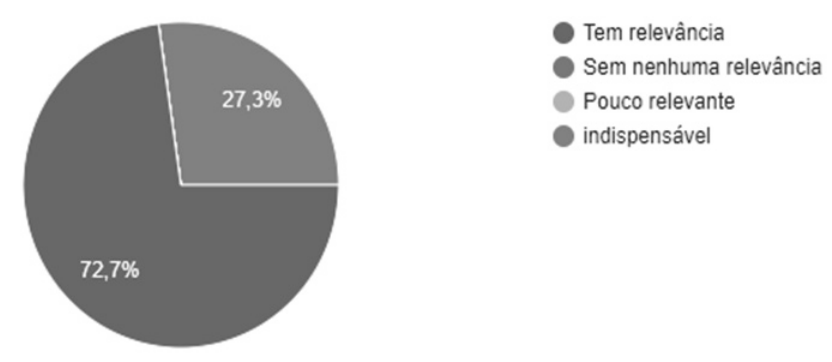

Gráfico 10 - Você considera o uso de recursos tecnológicos importante para o processo de ensino aprendizagem?

Fonte: Elaborado pelos autores (2019) 
Apesar das dificuldades apresentadas pelos professores, é sabido que a iniciativa e proatividade do professor é imprescindível para a adotação de novas metodologias ou tecnologias em sala de aula, para além das condições de infraestrutura física e lógica encontradas nas escolas.

Nesse sentido, é importante ressaltar que a prática pedagógica aqui relatada foi realizada em uma escola pública e, apesar da falta de infraestrutura, foi adotada uma metodologia de aprendizagem do ensino híbrida., a exemplo do plano de aula apresentado no quadro 1.

Quadro 1 - Plano de aula de ensino híbrido

\begin{tabular}{|c|c|c|c|c|c|c|}
\hline PROFESSOR & \multicolumn{2}{|c|}{ ANTÔNIO SOARES } & \multicolumn{2}{|l|}{ DISCIPLINA } & \multicolumn{2}{|c|}{ MATEMÁTICA/ENSINO MÉDIO } \\
\hline DURAÇÃO DA AULA & \multicolumn{2}{|c|}{ Duas ou mais de $50 \mathrm{~min}$} & \multicolumn{2}{|c|}{ No DE ALUNOS - 35} & \multicolumn{2}{|c|}{ SÉRIE/ANO: $1^{\circ}$ ano/2019 } \\
\hline METODOLOGIA & \multicolumn{6}{|c|}{ DE APRENDIZAGEM HÍBRIDA } \\
\hline CONTEÚDOS & \multicolumn{6}{|c|}{ SEQUÊNCIAS /PA E PG } \\
\hline OBJETIVO DA AULA & \multicolumn{6}{|c|}{$\begin{array}{l}\text { Identificar sequencia numérica e obter, quando possível, a expressão algébrica do seu termo. } \\
\text { Diferenciar progressões aritméticas de progressões geométricas }\end{array}$} \\
\hline $\begin{array}{l}\text { INTERAÇÕES } \\
\text { DO ALUNO }\end{array}$ & \multicolumn{6}{|c|}{$\begin{array}{l}\text { O aluno na plataforma virtual google sala de aula assistirá a vídeo aulas e aprenderá, e surgindo dúvi- } \\
\text { das, postará no ambiente de sala de aula, e acontecerá, por parte do docente, quanto do discente uma } \\
\text { interação virtual, e também em sala de aula presencial. }\end{array}$} \\
\hline \multirow[t]{2}{*}{ RECURSOS } & \multicolumn{6}{|c|}{ - Na sala de aula virtual - a utilização da internet com o auxílio da plataforma Google sala de aula. } \\
\hline & \multicolumn{6}{|c|}{$\begin{array}{l}\text { - Na sala de aula presencial - Lousa normal e demais materiais conhecidos a saber: cadernos, livros } \\
\text { didáticos etc. }\end{array}$} \\
\hline \multicolumn{6}{|c|}{ DESENVOLVIMENTOS DAS ATIVIDADES } & \\
\hline ESPAÇOS & & ATIVIDADES & TEMPO & & EL DO ALUNO & $\begin{array}{l}\text { PAPEL DO DO- } \\
\text { CENTE }\end{array}$ \\
\hline $\begin{array}{l}\text { ESPAÇO (1) } \\
\text { SALA VIRTUAL EM CASA } \\
\text { OU NÃO }\end{array}$ & & $\begin{array}{l}\text { Assistir a vídeo aula sobre } \\
\text { PA e PG na plataforma } \\
\text { google sala de aula. }\end{array}$ & $50 \mathrm{~min}$ & & $\begin{array}{l}\text { ir o vídeo quantas } \\
\text { s for necessário } \\
\text { se necessário suas } \\
\text { vações e dúvidas }\end{array}$ & $\begin{array}{c}\text { Primeiramente } \\
\text { orientar quanto ao } \\
\text { acessar a plataforma } \\
\text { google sala de aula } \\
\text { direcionando para } \\
\text { assistir o vídeo. }\end{array}$ \\
\hline $\begin{array}{l}\text { ESPAÇO (2) } \\
\text { SALA DE AULA PRESENCIA } \\
\text { Momento - } 1\end{array}$ & & $\begin{array}{c}\text { Refletir sobre os conteú- } \\
\text { dos do vídeo, destacando } \\
\text { algumas questões: } \\
1 \text { - Qual o assunto em } \\
\text { pauta? } \\
2 \text { - O assunto do vídeo } \\
\text { pode ser aplicado no dia } \\
\text { a dia. }\end{array}$ & $50 \mathrm{~min}$ & & $\begin{array}{l}\text { r, discutir sobre o } \\
\text { teúdo do vídeo. }\end{array}$ & $\begin{array}{l}\text { Fazer um registro } \\
\text { das dúvidas e con- } \\
\text { clusões do aluno. }\end{array}$ \\
\hline $\begin{array}{l}\text { ESPAÇO (2) } \\
\text { SALA DE AULA PRESENCIA } \\
\text { Momento - } 2\end{array}$ & & $\begin{array}{l}\text { Resoluções de questões } \\
\text { propostas pelo professor. }\end{array}$ & $50 \mathrm{~min}$ & $\begin{array}{r}\mathrm{Re} \\
\operatorname{pod}\end{array}$ & $\begin{array}{l}\text { er as questões que } \\
\text { em duplas ou não. }\end{array}$ & $\begin{array}{l}\text { Orientar, auxiliar } \\
\text { quando for neces- } \\
\text { sário. }\end{array}$ \\
\hline $\begin{array}{l}\text { ESPAÇO (2) } \\
\text { SALA DE AULA PRESENCIA } \\
\text { Momento - } 3\end{array}$ & & & $50 \mathrm{~min}$ & & & \\
\hline $\begin{array}{l}\text { ESPAÇO (3) } \\
\text { LABORATÓRIO DE INFOR- } \\
\text { MÁTICA }\end{array}$ & & - & - & & - & - \\
\hline
\end{tabular}




\begin{tabular}{|c|c|}
\hline \multicolumn{2}{|r|}{ AVALIAÇÃO } \\
\hline O QUE PODE SER FEITO PARA & - O docente analisa o desenvolvimento lógico matemático do discente no desdobramento das \\
\hline OBSERVAR SE OS OBJETIVOS DA & resoluções das questões propostas. \\
\hline AULA FORAM CUMPRINDOS? & - Isso no contexto da plataforma Google sala de aula com a utilização das videoaulas orientadas. \\
\hline $\begin{array}{l}\text { RECURSOS DE PERSONALIZA- } \\
\text { ÇÃO PÓS-AVALIAÇÃO }\end{array}$ & - Acompanhamento de tutoria por parte do docente. \\
\hline
\end{tabular}

\section{CONCLUSÃO}

A temática em si permite-nos concluir que a essa forma de metodologia, sem dúvida, funciona, desde que haja um bom planejamento e conhecimentos, tanto por parte dos professores e principalmente por parte dos alunos. A utilização da plataforma google sala de aula é muito interessante para estabelecer interações dentro do processo de ensino aprendizagem de qualquer área de conhecimento.

No dizer de Moran (2015),

As escolas não estão aproveitando todo o potencial que essas ferramentas trazem para que os alunos se transformem em autores, narradores, contadores de história e divulgadores. Os jovens adoram fazer vídeos, e a escola precisa incentivar ao máximo a produção de pesquisas . Moderna, como um meio contemporâneo, novo que imagem linguagem lúdica pela miniaturização da câmera, que permite brincar com a realidade, levá-la junto para qualquer lugar. Filmar é uma das experiências mais envolventes, tanto para crianças quanto para adultos. Os alunos podem ser incentivados a produzir dentro de uma determinada matéria ou dentro de um trabalho interdisciplinar (2015, p. 48).

Enfim, os docentes dentro deste novo cenário, em que estamos vivenciando essa crescente exponencial de recursos tecnológicos, a escola necessitam de novas estratégias metodológicas no processo de ensino aprendizagem. Entendo, que as plataformas virtuais como Openredu, Amadeus, Edmodo, Moodle e o Google sala de aula, todas são ferramentas de sistema de gestão de aprendizagem, para desenvolvermos esse tipo de metodologia, ou seja, metodologia híbrida, e associado a essa forma de aprendizagem, também utilizamos as vídeo aulas, evidencia possibilidades didáticas motivadoras, concretas para o processo de ensino aprendizagem de qualquer área de conhecimento . 


\section{REFERENNCIAS}

DANTAS, M. B.; OLIVEIRA, P. J. S. de. O cenário da educação a distância no Instituto Metrópole Digital. Anais... $4^{\circ}$ Colóquio Internacional de Pesquisas em Educação Superior. João Pessoa: UFPB, set. 2017. GIL, A.C. Como elaborar projetos de pesquisa. 4 ed. São Paulo: Atlas, 2008.

LIBÂNEO, José Carlos. Adeus professor, adeus professora?: novas exigências educacionais e profissão docente. São Paulo: Cortez, 1998 MORAN, José Manuel; MASETTO, Marcos T.; BEHENS, Marilda Aparecida Novas tecnologias e mediação pedagógica. 21. ed. rev e atual. Campinas, SP: Papirus, 2013. (coleção Papirus Educação).

MORAN, Mudando a educação com metodologias ativas. In: SOUZA, Carlos Alberto de. MORALES, Ofelia Elisa Torres (Orgs.). PG: Foca Foto-PROEX/UEPG, 2015. Coleção Mídias Contemporâneas. Convergências Midiáticas, Educação e Cidadania: Aproximações jovens. Vol. II.

SANTOS, João Almeida; PARRA FILHO, Domingos. Metodologia científica. 2. ed.- São Paulo: Cengage Learning, 2011.

SILBERMAN, M. Active learning: 101 strategies do teach any subject. Massachusetts: Allynand Bacon, 1996. 


\section{BRINC@RTE: A ARTE E O BRINCAR \\ COMO EXPERIÊNCIA INTERDISCIPLINAR NA EAD}

Renata Araújo

Cláudia Magalhães

Rafael Lira

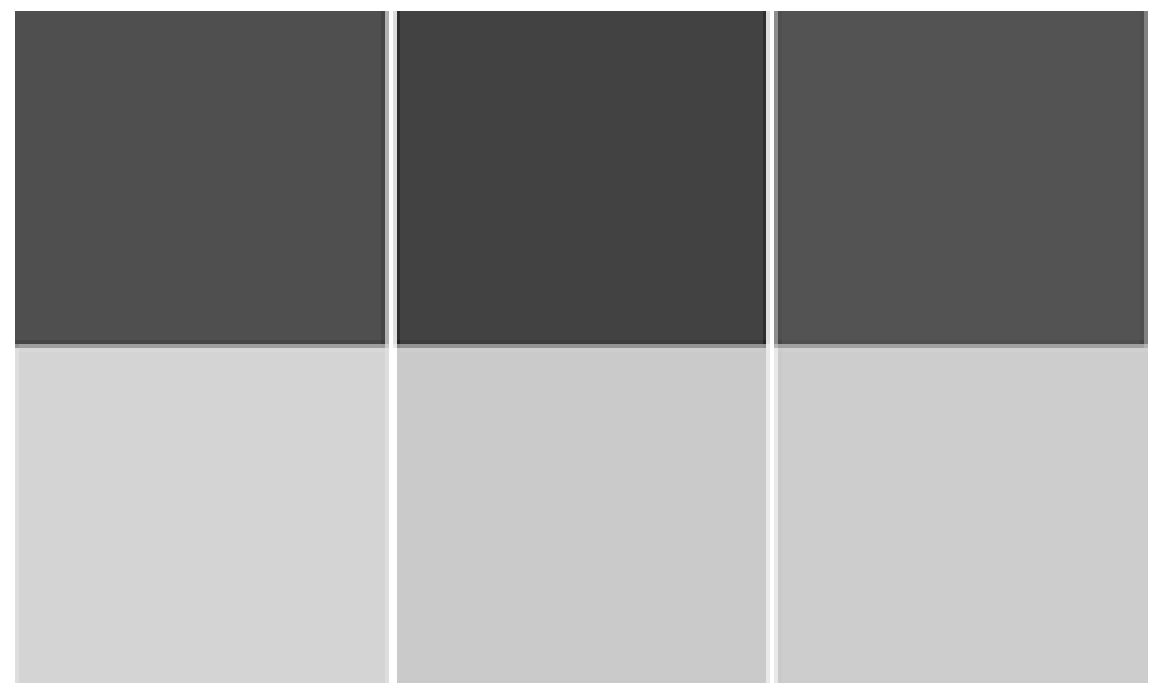




\section{INTRODUÇÃO}

O presente trabalho apresenta o relato de experência de um projeto de extensão em andamento, no ano de 2019, denominado Brinc@rte: brincando com arte para a aprendizagem da criança, realizado na Unidade Acadêmica de Educação a Distância (UAEADTec) da Universidade Federal Rural de Pernambuco (UFRPE), onde o ensino é em formato de Blended Learning, ou seja, semipresencial.

Inicialmente o projeto foi pensado para ser desenvolvido na Brinquedoteca criada em Outubro de 2018, primeiro espaço físico do brincar, como possibilidade de realização de atividades formativas e que aliasse ao espaço virtual de aprendizagem, sendo lócus de apoio ao ensino, pesquisa e extensão. Além disto, buscamos incentivar o desenvolvimento do Brinc@rte nos polos de apoio presencial dos diversos cursos de Licenciatura a Distância da Unidade Acadêmica de Educação a Distância.

$\mathrm{Na}$ atualidade, o projeto está caminhando para realização de suas atividades, oficinas, palestras, minicursos entre outros, não apenas na sede da UAEADTec em Recife, mas também nas escolas da rede pública e privada, bem como os polos de apoio presencial, como forma de não apenas integrar os alunos ao espaço como exercício acadêmico de monitoria, formação, pesquisa, extensão, mas expandir a ideia do Brinc@rte e suas experiências com todos nossos alunos $\mathrm{e}$ às comunidades locais de cada polo.

De tal modo, o debate iniciará com a temática do brincar e da arte como apoio às atividades presenciais e híbridas, a posteriori adentraremos no relato do Brinc@rte enquanto projeto de extensão, relatando a primeira ação do projeto, e, por fim, apresentaremos às considerações iniciais a respeito do mesmo.

\section{$1 \mathrm{O}$ brincar e a arte como potencializadores da aprendizagem no processo educativo presencial ou de Blended Learning}

A educação infantil, sendo um espaço de formação e socialização das crianças, constitui o momento de maior importância no desenvolvimento destas, a qual é salientada desde a Declaração Uni- 
versal dos Direitos da Criança (1959), que o Brasil ratifica em sua Constituição (1988/1990), e na Convenção sobre os Direitos das Crianças da organização das nações unidas (1989), adotada por mais de 196 países, dentre eles o Brasil, com o Estatuto da Criança e do Adolescente (ECA,1990). Este último, pontua que as crianças, consideradas de 0 a 12 anos incompletos, e os adolescentes, entre doze e dezoito anos de idade, tem direitos garantidos como educação, cultura, lazer, esporte, saúde, alimentação, dignidade, liberdade, respeito e convivência familiar e outros direitos, os quais são associados à Constituição da República de 1988. Destacamos para nossa discussão o capítulo $4 \mathrm{em}$ seu artigo 58, que discute o contexto educativo

No processo educacional respeitar-se-ão os valores culturais, artísticos e históricos próprios do contexto social da criança e do adolescente, garantindo-se a estes a liberdade da criação e o acesso às fontes de cultura (BRASIL, 1990, p.48).

Além destas legislações, temos a Lei de Diretrizes e Bases da Educação no 9394/96 que preza pela formação da criança em seu sentido integral tendo a Base Nacional Comum Curricular como direcionar das práticas educativas, considerando às características regionais e sociais, bem como da cultura e dos educandos. Assim, o brincar, sendo uma linguagem do universo da criança, é considerado como elemento primordial.

Compreendemos assim, que o brincar vem sendo legitimado há tempos, internacional e nacionalmente, reconhecendo o direito da criança ao descanso, lazer, brincar, às atividades recreativas, livres e a plena participação na vida cultural e artística.

Na visão de Kishimoto (2012), o brincar possui duas facetas, podendo ser direcionado como ferramenta para o ensino dos conteúdos ou como livre atividade. Contudo, ambos os aspectos representam igual importância no que concerne ao desenvolvimento infantil. O uso de brinquedos e jogos nem sempre foi valorizado como ferramenta importante para uso pedagógico, ao contrário, era visto como forma de recreação, uma vez considerado como dispêndio de tempo que deveria ser dedicado ao trabalho dos conteúdos escolares. Os primeiros estudos acerca da relevância do jogo na educação se 
situam desde a Roma e Grécia antiga com Platão e Aristóteles. Contudo, é a partir do século XX, com Froebel, que o jogo passa a ser entendido como objeto e ação de brincar passando a fazer parte da educação infantil, apesar dele enfatizar o jogo livre como importante para o desenvolvimento das crianças.

Tratando-se do conceito do brincar, De Conti e Sperb (2001) nos fala da importância desta atividade para o desenvolvimento infantil como sendo algo consensual entre os teóricos, entretanto, quando se fala em definir o brincar, a imprecisão permanece. Levando em consideração o âmbito histórico as autoras mencionam

\begin{abstract}
Uma das primeiras teorias sobre o brincar infantil, por exemplo, surgiu no século XVIII e entendia esta atividade como o produto de uma energia excedente (Groos,1896/1976). Já os estudiosos que dominaram as teorias do brincar na primeira metade do século XX, como Piaget (1945/1978) e Vygotsky (1933/1989), definem o brincar a partir da sua relação com o desenvolvimento psicológico mais amplo. Posteriormente, temos teóricos como Berlyne (1963) que explica o brincar como um comportamento intrinsicamente motivado; e Bruner (1972/1976) que postula o brincar como uma atividade que deve facilitar a aprendizagem e/ou a prática de comportamentos específicos. Um outro enfoque teórico (Schwartzman,1978) enfatiza as relações entre texto e contexto no brincar infantil. Dele derivam os estudos preocupados em estabelecer o papel dos diferentes contextos na estruturação do brincar (p. 1).
\end{abstract}

Podemos entender deste modo, que o brincar perpassou uma evolução no sentido de uma atividade desconsiderada socialmente e, portanto, era momento de desperdício de tempo pela criança, para uma visão que considera esta atividade como fundamental no desenvolvimento da mesma, nos diferentes contextos em que ela possa acontecer.

Adentrando as concepções acerca do brincar, estas sabemos que não são unívocas e se colocam como obstáculo devido à designação de vários termos como sinônimos, onde jogo, brincadeira e brinquedo são vistos como de mesmo significado para alguns autores e outros percebem como divergentes. Contudo, consideraremos estes termos segundo o olhar de Kishimoto (2012) que concebe o brinquedo como o suporte da brincadeira, visualiza a brincadeira como descrição de uma conduta estruturada, com regras além de designar o jogo infantil tanto o objeto quanto às regras do jogo da criança. 
Acerca da conceituação do brincar, os defensores das teorias externalistas o percebem como forma de distração e dispêndio de tempo, sendo assim, não valorizam o espaço para este na escola, o que por muito tempo influenciou as práticas educativas dos educadores da educação infantil. Em contrapartida, outros estudiosos como Piaget e Vygotsky, que discutem os processos internos que estão relacionados com o comportamento lúdico, atribuem ao brincar um papel importante para o desenvolvimento cognitivo da criança.

As produções científicas destes teóricos contribuíram para a percepção do caráter primordial desta inserção do brincar no espaço educativo bem como para as discussões e pesquisas acerca desta importante temática. O brincar se consolida como uma atividade em que a criança sente o mundo que a cerca, interagindo, conhecendo, superando obstáculos, dispendendo energia, percebendo-se neste contexto e desenvolvendo, neste caminhar, os seus futuros papéis sociais.

O brincar, segundo Piaget (2010) e Vygotsky (2015), mesmo que denominado de formas diferentes e enfatizado por eles em aspectos distintos, apresenta momentos que possibilitam o desenvolvimento da criança. Para Piaget (2010), desde o período considerado pela ação mais sensorial e imitativa, passando pela imaginação simbólica e por fim o jogo de regras, as crianças aprendem e se desenvolvem física, emocional e cognitivamente através do e pelo brincar. Para Vygotsky (2015, p.81)

O brincar é fonte de desenvolvimento e de aprendizagem, constituindo uma atividade que impulsiona o desenvolvimento, pois a criança se comporta de forma mais avançada do que na vida cotidiana, exercendo papéis e desenvolvendo ações que mobilizam novos conhecimentos, habilidades e processos de desenvolvimento e de aprendizagem.

Assim, no brincar e na interação consigo e com o outro, o jogo simbólico e suas formas de representação, que é impulsionada pela imitação, faz a criança antecipar os papéis sociais de seu contexto cultural que irá assumir quando adulta, o que traz grande desenvolvimento cognitivo, emocional e social.

Segundo Fortuna (2007) o brincar desenvolve a imaginação, afetos, competências a nível cognitivo e oriundas da interação, pois é 
por meio deste que a criança se comunica, demonstra os sentimentos que estão ocultos. Além disto, quando as crianças estão no ato do brincar, seja de forma individual ou em grupo, são vividos momentos ricos de aprendizagem.

Na visão de Borba (2006) o brincar favorece olhar o mundo de outra maneira, dando novos significados e espaço de perguntar, negociar, trocar bem como regular as ações individuais com as coletivas. A partir desta fala, podemos perceber que "os processos de desenvolvimento e de aprendizagem envolvidas no brincar são também constitutivos do processo de apropriação do conhecimento" (BORBA, 2006, p. 39). Portanto, o envolvimento das crianças em atividades lúdicas, possibilitará o crescimento saudável tanto emocionalmente quanto fisicamente, de um adulto que vivenciou na sua infância as etapas do brincar. A ludicidade dentro dos processos de ensino e aprendizagem é fundamental para humanizar os espaços da escola em todas as etapas da escolarização e trazer a dimensão do prazer e do encantamento para as experiências de aprendizagem.

É indiscutível a importância do lúdico na educação, na construção da identidade da criança em seu processo de desenvolvimento cognitivo, social e afetivo. O lúdico pode ser considerado uma grande categoria na qual se inserem subcategorias diversas, entre as quais o jogo, o brinquedo e a brincadeira. $O$ jogo pode ser entendido como um rol de atividades que podem ser realizadas em grupo ou individualmente. O brinquedo é o objeto manipulável com o qual a criança brinca, podendo ser um objeto concreto ou abstrato, imaginativo. A brincadeira é a ação de brincar ou de jogar.

A criança é um ser brincante e essa característica precisa ser cultivada ao longo de toda a vida. A atividade de brincar precisa ser resgatada e incentivada tanto na família quanto na escola, nos espaços de interação social, como praças, igrejas, clubes. O processo de aprender e o processo de brincar devem se dar juntos, em um movimento que tem como base o aprender como descoberta, curiosidade, ludicidade e interação.

Para além do tratamento do Brincar vemos a interpelação com a Arte como de fundamental importância no desenvolvimento holístico humano. Compreendemos que a Arte é a primeira forma de expressão pela qual a criança transmite ao outro o seu olhar 
e compreensão acerca do mundo em que vive, estabelecendo por meio da mesma um canal de comunicação, antes mesmo da fala e da escrita, e assim, podemos considerar a Arte como uma área do conhecimento onde o lúdico se faz presente de forma intrínseca. $\mathrm{O}$ estímulo a produções artísticas constrói no aluno uma experiência estimulante, fortalecendo as suas próprias decisões e compressão do mundo que o cerca.

A Arte é multifacetada, plural, técnica, uma tecnologia humana, uma invenção que comunica, expressa, que tem significados plurais e que se relacionam com a vivência do homem ao longo de toda sua construção socio-histórica. Na atualidade temos muitas significações do que é Arte, de suas formas de construção e inclusive da participação dos sujeitos, que antes se davam em contemplar a produção artística e hoje tem formas de interatividade com os elementos diversos desta construção humana que fascina, incluindo as tecnologias digitais de informação e comunicação. De acordo com Aguiar e Bastos (2013, p.199-200) "a arte é, portanto, em determinadas expressões mais significativas dos últimos decênios, um conceito, uma máquina produtora de conceitos e de imagens sobre si. É uma metáfora sobre a própria arte".

A metodologia criada por Ana Mae Barbosa em 1987, pioneira da Arte Educação no Brasil, denominada de Abordagem Triangular, apoiando-se nos elementos da teoria de Paulo Freire edifica um repertório no aluno para as suas produções artísticas. Os comportamentos de criação da arte aprendidos são utilizados no processo de aprendizagem em outras áreas do conhecimento e, por isso, esta é de suma relevância estar presente nos diversos níveis de formação escolar.

A abordagem triangular é uma proposta metodológica que consiste em três vertentes: Contextualização histórica, Apreciação artística e o Fazer artístico. No eixo "Contextualização histórica" é abordado o momento histórico da produção de determinada obra artística, os dados do artista, o tipo de sociedade e cultura da época, e neste o aluno compreende a importância da obra, conhece seu histórico. Na "Apreciação Artística", o aluno realiza a leitura da obra de maneira crítica, olhando para o estético da obra bem como introduzindo seus conhecimentos, sentimentos e percepções, ou seja, comentando a obra, lendo com suas lentes. No terceiro eixo temos o 
"Fazer Artístico", onde depois de conhecer a história da obra e realizar a sua leitura, o aluno assume o papel do artista a partir da criação de sua versão original da obra. Os três processos organizam o conhecimento em relação a produção artística, gerando no aluno um aprendizado efetivo (BARBOSA; CUNHA, 2012).

Podemos ver que a partir desta Abordagem Triangular, a Arte tem grande importância intelectual e cognitiva, e assim, é imprescindível os docentes investirem nas escolas em atividades relacionadas com os três eixos, buscando fazer com que os estudantes possam analisar, descrever, criar a partir do que se está estudando enquanto obra, para que se possa realmente ser construído o aprendizado de maneira que tenha significado para o aluno, sendo também criativa e lúdica.

A LDB 9394/96 em seu artigo 26, na segunda alínea coloca que o ensino da Arte é componente curricular obrigatório da Educação Básica, enfatizando suas expressões regionais, como forma de possibilitar o desenvolver cultural dos alunos, levando em consideração a cultura, economia e a realidade dos educandos. Adentrando a Base Nacional Comum Curricular (BNCC), que é o novo documento de base para a Educação em nosso país, estão garantidos os direitos de aprendizagem e desenvolvimento na Educação Infantil relacionados para além do conviver e conhecer a si mesmo, ao Brincar e também a Arte, conforme podemos vislumbrar no extrato abaixo:

Brincar cotidianamente de diversas formas, em diferentes espaços e tempos, com diferentes parceiros (crianças e adultos), ampliando e diversificando seu acesso a produções culturais, seus conhecimentos, sua imaginação, sua criatividade, suas experiências emocionais, corporais, sensoriais, expressivas, cognitivas, sociais e relacionais; Participar ativamente, com adultos e outras crianças, tanto do planejamento da gestão da escola e das atividades propostas pelo educador quanto da realização das atividades da vida cotidiana, tais como a escolha das brincadeiras, dos materiais e dos ambientes, desenvolvendo diferentes linguagens e elaborando conhecimentos, decidindo e se posicionando; Explorar movimentos, gestos, sons, formas, texturas, cores, palavras, emoções, transformações, relacionamentos, histórias, objetos, elementos da natureza, na escola e fora dela, ampliando seus saberes sobre a cultura, em suas diversas modalidades: as artes, a escrita, a ciência e a tecnologia; Expressar, como sujeito dialógico, criativo e sensível, suas necessidades, emoções, sentimentos, dúvidas, hipóteses, descobertas, opiniões, questionamentos, por meio de diferentes linguagens (BRASIL, 2018, p.38, grifo do autor). 
Percebemos que o brincar e a arte são elementos que devem fazer parte do processo educativo infantil, pois possibilita a criança desenvolver autonomia, imaginação, criatividade, explorar sua cultura de modos multifacetados, o que favorece aprendizagem.

A BNCC ainda coloca de maneira específica as competências do componente curricular Artes para o Ensino Fundamental, que devem contemplar as seguintes linguagens: Artes Visuais, Dança, Teatro e Música. Tais linguagens devem se articular de modo a promover saberes referentes tanto a produtos quanto a fenômenos artísticos, dentro de um processo de criação, leitura, construção, exteriorização e reflexão das formas diversas que se manifesta a Arte. Assim, o aluno desenvolve

A sensibilidade, a intuição, o pensamento, as emoções e as subjetividades se manifestam como formas de expressão no processo de aprendizagem em Arte. O componente curricular contribui, ainda, para a interação crítica dos alunos com a complexidade do mundo, além de favorecer o respeito às diferenças e o diálogo intercultural, pluriétnico e plurilíngue, importantes para o exercício da cidadania. A Arte propicia a troca entre culturas e favorece o reconhecimento de semelhanças e diferenças entre elas (BRASIL, 2018, p.193).

Vemos assim, que a função da Arte é de analisar, criticar e refletir socialmente sobre a realidade humana, devendo ser muito mais que adquirir códigos e técnicas. Neste sentido, Barbosa (2012) retrata que por meio da Arte é possível desenvolver a percepção, imaginação, apreender a realidade do ambiente sócio-cultural, desenvolver a capacidade crítica, a criatividade de maneira a mudar a realidade em que vive, sendo assim ator da mesma.

Só é possível construir e organizar conhecimento na área de Artes por meio de investigação, ou seja, a pesquisa é importante para a construção do saber neste componente curricular. Salienta-se ainda na BNCC as seis dimensões do conhecimento que devem ser trabalhadas na Arte: 1-Criação: fazer artístico, construir; 2-Crítica: sujeito questionar o mundo que vive; 3-Estesia: experiência sensível dos sujeitos quanto ao espaço, tempo e outros.; 4- Expressão: exteriorizar produções individuais e coletivas; $\underline{5-F r u i c ̧ a ̃ o: ~ d e l e i t e, ~ p r a z e r, ~}$ 
estranhamento, abertura para se sensibilizar com a arte; e 6-Reflexão: construir argumentos mediante as vivências em práticas artísticas e culturais (BRASIL, 2018, p. 194-195).

A Arte com suas técnicas plurais devem ser conhecidas e contempladas nos espaços educativos, pois não se concebe a humanidade sem a Arte, e, por conseguinte, não se pode ter educação no sentido pleno sem considerar a mesma. Brincar é uma forma de conhecer o mundo, ampliar os horizontes, de enriquecer a vida, de considerar a linguagem da criança e, a Arte é uma área do conhecimento onde o lúdico se faz presente de forma intrínseca. Unir Arte e Brincar em um processo de dialogicidade na Educação pode imprimir prazer ao cotidiano escolar, pois ambos fazem parte do universo da criança, uma vez que a brincadeira e as diversas formas de manifestações artísticas são estratégias que podem potencializar a conquista da autonomia e da criticidade, aprendizagem em seu sentido amplo.

O lúdico e o fazer artístico podem ser o diferencial para o sucesso de todas as aprendizagens, considerando não apenas os conhecimentos conceituais mas também os procedimentos e as atitudes, em todas as etapas da escolarização, da educação infantil até a educação acadêmica e também nas aprendizagens não formais, realizadas na interação com o mundo e com as pessoas. Logo, são também categorias que podem contribuir para o desenvolvimento da afetividade e para os processos de socialização.

Nesta perspectiva, o lúdico na educação não pode ser considerado com uma prática não seria ou de pouca relevância. O professor precisa desenvolver a consciência de que a ludicidade nas práticas de ensino é uma ferramenta muito importante, que deve ser levada muito a sério, precisa ser planejada e ter intencionalidade. sendo assim, ao organizar as atividades de ensino com a utilização de estratégias como a brincadeira, o jogo e a arte, enquanto área de conhecimento,o professor pode priorizar diferentes aspectos: o desenvolvimento da estima, do afeto, da simpatia, da empatia, dos valores. Tais aspectos são fundantes para o desenvolvimento das crianças como seres integrais e complexos.

Assim sendo, a brincadeira e a arte são formas de experiências, de múltiplos movimentos e de sensações, que alicerçam a maneira do sujeito estar no mundo. São momentos de ensinar o outro e de 
aprender, socializando, interagindo. O brincar associado à arte é uma forma de a criança expressar seu ser, suas construções sociais, meus medos, enfim, é uma maneira de entender como a criança pensa e está construindo o universo que a cerca.

Aliar o brincar com a arte pode potencializar as práticas educativas, tanto no ensino presencial como também no Blended Learning ou ensino híbrido, que significa o imbrincar do presencial e do online, e que Moran (2015) traz como um conceito amplo, alegando que é um conceito rico, complexo, que remete à mistura. Ainda segundo o autor, na educação híbrida pode remeter a saberes, valores, quando temos várias áreas juntas, seja de modo disciplinar ou não; de metodologias, com desafios, atividades, games, enfim, atividades individuais e em grupos personalizadas; temos tecnologias híbridas, que tem como cerne integrar as atividades de sala de aula com as digitais, ou seja, o ensino presencial e virtual; e, ainda fala de híbrido tanto em um currículo mais flexível e personalizado, quanto também articular o informal com o formal, sintetizando que é mistura e integrar áreas, professores e diferentes alunos, em espaço/tempo diferenciados.

Sendo assim, vemos que tanto o brincar, a arte, a interdisciplinaridade as ações de remixar conhecimentos, pessoas, tempos e espaços de educar, presencial e online, só tem a potencializar as práticas educativas seja na Educação Básica, fazendo com que se aprenda de maneira lúdica, prazerosa, criativa e significativa, seja no Ensino Superior, que prepara os profissionais para tal cenário e que precisa considerar estas singularidades para uma formação qualitativa, crítica e que vise a melhoria do processo educativo.

\section{BRINC@RTE: ESPAÇO DE EXPERIÊNCIAS FORMATIVAS NA PESQUISA E FORMAÇÃO DOCENTE E DISCENTE}

O projeto Brinc@rte surgiu a partir da criação da brinquedoteca da Universidade Federal Rural de Pernambuco (UFRPE) em Outubro de 2018. Este espaço é denominado Espaço Tec/EAD, próximo a reitoria, pertence a Unidade Acadêmica de Educação a Distância (UAEADTec), sendo de acesso também aos cursos presenciais da instituição. A brinquedoteca foi uma criação coletiva a partir da universidade, com a concessão do espaço, da UAEADtec, custeando materiais 
para sua construção e móveis, professores e sociedade, uma vez que estes doaram para o acervo desde livros infantis a brinquedos diversos, e alunos dos cursos de licenciatura, que foram selecionados como monitores e fizeram parte da arrumação e setorização da mesma.

A Brinquedoteca é composta de diversos espaços para se trabalhar com o lúdico, dentre eles: 1-Espaço da leitura e contação de histórias; 2-Espaço das Brincadeiras livres e dirigidas; 3-Espaço de Teatro; 4-Espaço de Brinquedos Regionais e de sucata, o qual podemos vislumbrar nas imagens:

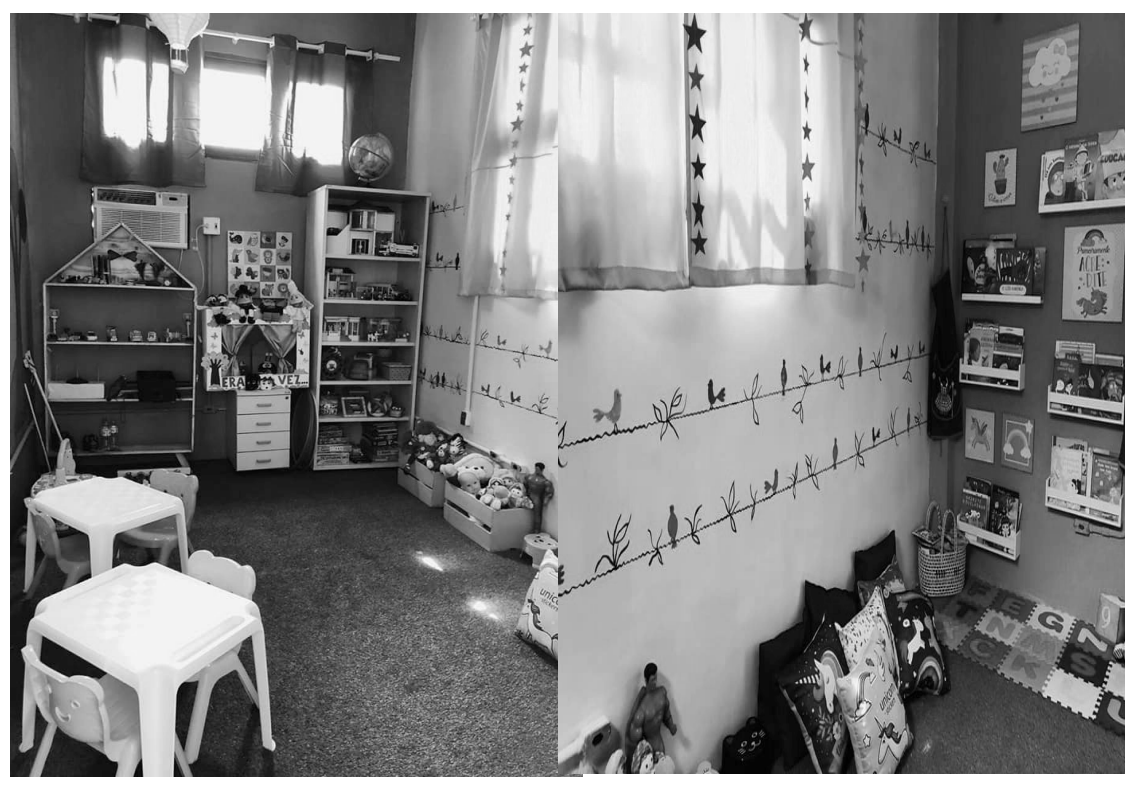

Fotos: Brinquedotec

Fonte: Equipe de Produção Audiovisual/UFRPE.

A partir de um espaço que privilegia à formação dos nossos licenciados para uma docência que considere o lúdico, o qual é preponderante no universo da criança, e por conseguinte, na Educação Básica, criamos o projeto Brinc@rte: brincando com arte para a aprendizagem da criança.

O Brinc@rte é um projeto de extensão, com foco na formação docente, o qual tem como objetivo realizar formação inicial e continuada acerca do brincar aliado a arte como forma de promover 
uma educação inovadora, interdisciplinar e lúdica tendo como público alvo docentes e discentes das diversas licenciaturas da UFRPE, Prefeitura do Recife, Escolas Parceiras privadas e públicas e Comunidade Local.

Envolvendo diversas licenciaturas que compõem a UAEADTec, como os cursos de Pedagogia, Artes Visuais, Física, História e Computação, o Brinc@rte é interdisciplinar, buscando caminhar para uma prática formativa a partir do lúdico, ativa e inovadora e, que venha a modificar a postura profissional de nossos alunos para uma Educação Básica com cada vez mais qualidade no futuro.

O projeto Brinc@rte respeita o ideário do Ensino Superior como nível educativo que tem como propósito o Ensino, a Pesquisa e Extensão interligados, o qual destaca Severino $(2017$, p.22) tal tríplice finalidade da universidade, que seria "profissionalizar, iniciar à prática de científica e formar a consciência político-social do estudante".

No âmbito do ensino o projeto dar conta da formação de profissionais licenciados, das diferentes áreas do conhecimento, tenho como eixos centrais a Educação e a Arte, mas sendo interdisciplinar com as demais ciências. Preocupa-se em realizar o desenvolvimento de competências considerando o processo de ensino de maneira construtivista e conforme coloca Zabala (2014) em suas 4 tipologias: conteúdos factuais, conceituais, procedimentais e atitudinais.

Esta preocupação com o ensino é articulada com os 4 pilares da Educação para o Século XXI, onde no Relatório para Unesco para a Comissão Internacional sobre a Educação no Século XXI, que deve ser concretizada ao longo da vida, e pontua Jacques Delores (2012): Aprender a conhecer: que seria o aprender a aprender para poder dar continuidade ao processo formativo ao longo da vida; Aprender a fazer: como forma de obter não apenas uma formação profissional, mas competências de maneira ampla, que possam favorecer as situações de sua prática e no trabalho em equipe, e portanto, aprender é essencial aos jovens nas diversas experiências sociais ou de trabalho, tanto a nível comunitário ou nacional; Aprender a conviver: que se refere ao desenvolver dos discentes da compreensão do outro e de sua interdependência, no sentido de realização de trabalhos comuns, respeitando as singularidades, e os valores como pluralismo, compreensão mútua e paz; e, por fim, o Aprender a ser: que seria 
os discentes desenvolverem sua subjetividade, personalidade, terem condições de agir de maneira autônoma, conseguindo compreender e discernir situações e com responsabilidade pessoal e social, e neste sentido, tal aprender considera as potencialidades do indivíduo de formas diversas como memória, raciocínio, sentido estético, capacidades físicas, aptidão para saber se comunicar dentre outras.

Adentrando ao âmbito da Pesquisa, entendendo a pesquisa como componente fundamental do processo de ensino, envolvemos as disciplinas dos cursos envolvidos no projeto Brinc@rte, incentivando os alunos não apenas a participar dos processos formativos, mas de também utilizarem o projeto como fonte de pesquisa.

No aspecto da Extensão, os alunos irão interagir tanto com alunos e professores das escolas municipais, como atuar na sede da Brinquedoteca em Recife, participando como monitores das oficinas e minicursos para comunidade local, levando assim o conhecimento construído ao longo do projeto à comunidade, numa forma de aprender considerando os 4 pilares da Educação do Século XXI citados anteriormente. A extensão para além de uma exigência da ação universitária possibilita aos licenciados o alcance pedagógico segundo (SEVERINO, 2017, p.32) "levando o jovem estudante a vivenciar sua realidade social". Ainda pontua o autor que a extensão se relaciona à pesquisa, tornando-se relevante para a produção de conhecimento, porque esta produção deve ter como referência objetiva os problemas reais e concretos que tenham a ver com a sociedade envolvente.

[...] a relevância temática dos objetos de pesquisa é dada pela significação social dos mesmos. É o que garante que a pesquisa não seja desinteressada ou neutra [...] por sinal, a prática da extensão deve funcionar como cordão umbilical entre a Sociedade e a Universidade, impedindo que a pesquisa prevaleça sobre as outras funções[...] (SEVERINO, 2017, p.33).

Portanto, o projeto Brinc@rte tem como propósito a formação inicial e continuada de professores envolvendo a tríade ensino, pesquisa e extensão, bem como a interdisciplinaridade das ciências e multiplicidade de espaços de atuação como forma de ser um projeto ativo, construtivo por todos, com participação de sujeitos diversos e visando em seu cenário maior unir o brincar com a arte, em suas 
diversas facetas, como processo de formação de docentes para uma educação lúdica e inovadora.

Entendemos que a interdisciplinaridade é trazida por variados autores, mas adotamos neste trabalho o olhar de atitude, de encontro, que Assumpção (2011, p.22-23) mostra no extrato que

[...] A interdisciplinaridade nomeia um encontro que pode ocorrer entre seres - inter - num certo fazer - dade - a partir da direcionalidade da consciência, pretendendo compreender o objeto, com ele relacionar-se, comunicar-se. Assim interpretada, esta supõe um momento que a antecede, qual seja a disposição da subjetividade, atributo exclusivamente humano, de perceber-se e presentificar-se, realizando nessa opção um encontro com-o-outro, a intersubjetividade.

Portanto, vemos que interdisciplinaridade é o diálogo entre as disciplinas, entre as docências, em um momento de saída do disciplinar, de ver o conhecimento de maneira atrelada, suas relações, sendo assim, segundo Fazenda (2011) ela requer ação, não sendo uma categoria de conhecimento.

É compromisso da universidade formar profissionais para a Educação Básica com qualidade, e ao nosso olhar, isso prescinde que entendam que o educar precisa estar aliado a realidade dos sujeitos aprendentes, que são as crianças e adolescentes, bem como considerar a Arte em suas diversas linguagens como elos importantes do desenvolvimento humano, considerando a interdisciplinaridade como base para um pensar holístico. O Brinc@rte, busca concretizar esta ação formativa interdisciplinar, lúdica e que venha a promover aprendizagens significativas para os discentes em formação, o que favorecerá a melhoria da qualidade dos educadores na Educação Básica, de sua práxis pedagógica.

Entendemos que é preciso desenvolver a consciência de que a ludicidade nas práticas de ensino é uma ferramenta muito importante, que deve ser levada muito a sério, precisa ser planejada e ter intencionalidade. Ao organizar as atividades de ensino com a utilização de estratégias como a brincadeira, o jogo e a Arte, o professor pode priorizar diferentes aspectos: o desenvolvimento da estima, do afeto, da simpatia, da empatia, dos valores, das relações entre os pares, 
consigo mesmo, de uma compreensão ampla e crítica do tempo social e cultural vivenciado, e assim, formar um cidadão que possa dar conta das necessidades da atualidade. Além disto, o lúdico, a arte e a associação com a interdisciplinaridade com as outras ciências como História, Física, Letras, Computação, para além da Educação e Artes Visuais, só tendem a construir um processo formativo para os discentes das diversas licenciaturas da UFRPE de modo a conscientizar da importância do holístico na formação humana, tendência esta já pontuada na atual Base Nacional Comum Curricular.

Diante do que foi colocado, chama a atenção a importância dos processos de formação de professores, em que a ludicidade e a expressão artística em suas diversas facetas, sejam entendidas como estratégias pedagógicas indispensáveis e que caminhem para um processo educativo interdisciplinar. Espera-se contribuir, ao longo do mesmo, com o fortalecimento da formação inicial e continuada dos educadores e com a construção de sua identidade docente em prol de processos interdisciplinares, em que as práticas de ensino tenham como estratégia a brincadeira, o jogo e a arte em suas mais variadas linguagens: a dança, a música, as artes visuais, incluindo as expressões digitais, a literatura, o teatro; e, também, as demais ciências, que citamos anteriormente.

Neste sentido, é importante ressaltarmos como cada um dos cursos de licenciatura de nossa unidade que estão envolvidos no projetoBrinc@rte.

O Curso de Licenciatura em Pedagogia a Distância vem colaborar na reflexão da formação inovadora dos docentes para a Educação Básica, considerando o aspecto científico, técnico, pedagógico e social, e preocupada em trazer o processo de ensino aprendizagem através de metodologias ativas, lúdicas e criativas. Dará oficina associada à formação ambiental, à consciência ecológica, mostrando como os materiais que são considerados por muitos lixo, podem se tornar criações de diversos tipos, dentre elas, brinquedos.

A Licenciatura em Artes Visuais com Ênfase em Digitais traz a produção artística e cultural e a tecnologia sendo elemento de base, e com suas diversas linguagens que consideram a Educação por um olhar amplo, lúdico e humano em suas múltiplas inteligências. Assim, haverá diversas oficinas, palestras e minicursos envolvendo temáticas 
como animação, produção audiovisual, teatro, jogos cantados, elaboração de história em quadrinhos, representação bi e tridimensional, e eventos que valorizem a arte e suas linguagens associados às disciplinas de estágio, práticas como componente curricular e produções do projeto Brinc@rte. Serão realizadas com as crianças oficinas de pintura com aquarela, origami, colagem, trabalho com mosaico de EVA, impressão por meio do exercício da monotipia, brincar e fazer arte com argila e oficina de animação.

A História assume uma perspectiva de explorar memórias, culturas, narrativas, onde as diferentes temporalidades estejam presentes e que seja reconhecida pelos sujeitos participantes. Assim, abarca os aspectos familiares, culturais, sócio-históricos, as quais são aspectos que constituem na realidade as vivências dos sujeitos no tempo. Através das múltiplas linguagens das Artes e da ludicidade, a História se aproxima das experiências dos sujeitos e das suas formas de dialogar, de ouvir, de sentir no tempo.

O Curso de Licenciatura em Física contribui com a proposta de se trabalhar com os conceitos de Eletricidade, Termodinâmica, Ondulatória entre outros, que mesmo não sendo trabalhamos na Educação Infantil e Ensino Fundamental I, fazem parte da vida das crianças. De maneira lúdica, a partir da confecção de brinquedos e/ou jogos populares como vai e vem, telefone sem fio, cabo de guerra, jogos de corda, jogo de tabuleiro, caleidoscópio, boliche dentre outros, coloca o brincar como recurso instrucional. Tal fator contribui como ferramenta pedagógica para construção de conceitos científicos de maneira direcionada, inovada e lúdica, sendo poderosa ferramenta para o ensino das Ciências. Serão discutidas as Ciências em seu sentido amplo, tratando de questões biológicas, ambientais, climáticas, geográficas, para que as crianças compreendam não apenas seu lugar no mundo enquanto ser biológico, mas a vida em sua complexidade. De tal modo, as atividades com os docentes e discentes no sentido de formação para educar para as questões ambientais com atividades lúdicas, tema transversal e fundamental para a formação humana, principalmente no século XXI, e que a Física trabalhará de modo também interdisciplinar, como as outras ciências.

Uma docente com formação na área de Letras vem com o propósito de abordar o uso da Língua Portuguesa e literaturas, com foco 
formativo na área de linguagem em suas diversas expressões como oralidade, leitura, produção de textos entre outras. Assim, será construída oficina abordando lendas do folclore brasileiro, suas contações e vivências, no intuito de incentivo à leitura pela criança. A contação de histórias é de suma relevância para a criança, pois desperta imaginação, interesse, incentivo à leitura e ao aprendizado. Através da história se tem a possibilidade de preservar as culturas, trabalhar valores múltiplos, enfim, estimular o aprendizado por meio da oralidade e caminhando para as demais expressões da linguagem.

Em relação ao Curso de Licenciatura em Computação, que tem como objetivo formar educadores com base nas áreas de computação e técnicas de informática, com ênfase em aspectos científicos, técnicos, pedagógicos e sociais, pensando na inovação da Educação, traz para o projeto a contribuição com o Brinc@rte virtual, que será um espaço virtual para divulgação dos trabalhos realizados por todos os cursos no projeto, como forma de integrar à equipe e poderem ser vistas por quem não participou presencialmente. Além disto, este lócus virtual visa disponibilizar materiais de aporte teórico para o aprofundamento da formação do público alvo do projeto, no interior e exterior a academia. O curso também traz atividades do projeto preparadas e disseminadas por tecnologias da informação, desde o processo de inscrição dos sujeitos participantes, divulgação de como ocorreu as oficinas e resultados do projeto de forma a partilhar as construções científicas ao longo do mesmo.

Também temos colaboradores no projeto de outra instituição federal que vem com a proposta de tratar o Estatuto da Criança e do Adolescente, voluntária técnica de nossa instituição, abordando o lúdico e a arte como propulsores de aprendizagem, bem como voluntários externos, que irão realizar oficinas e minicursos voltados a temática associada do Brincar e da Arte.

Apesar de mostrarmos o que cada disciplina contribui de maneira isolada, trabalhamos de forma integrada, com uma equipe que dialoga de forma contínua, para planejar às ações, contudo, sem perder cada curso sua disciplinaridade. Por sua vez, teremos diversas oficinas, minicursos e palestras que contemplam a importância do 
olhar de todas estas disciplinas em uma busca de integração, pois cada uma delas em seu objeto de estudo científico podem se aliar, por fazer parte da formação do humano, e assim, contribuem para pensarmos e concretizarmos novas formas de fazer educação.

Vemos que Arte, Educação e Interdisciplinaridade com as ciências diversas só tendem a contribuir, principalmente na Educação Infantil e séries iniciais do Ensino Fundamental I, onde a criança estar em processo de construção de sua identidade, com uma formação humana holística, significativa e cidadã. Este é o foco do Brinc@ rte, fazer com que não apenas o brincar e a Arte dialoguem, mas as diversas ciências que compõem a formação do licenciando, para que de forma interdisciplinar possa se formar e atuar em um processo de ensino e aprendizagem inovador e que considere o lúdico como elemento primordial, por fazer parte do universo simbólico da criança.

A equipe do projeto é composta por docentes das diversas licenciaturas da UAEADTec, além de monitoras voluntárias, discentes de nossos cursos, que ajudam no planejamento e realização das atividades. A primeira ação do projeto foi “O Brinc@rte na V Semana do Bebê do Recife", que aconteceu em 22 de maio de 2019, no Centro de Educação Comunitária Gabriela 2", onde foi desenvolvida atividades de Teatro de Fantoches, Contação de Histórias, Fada do Dente e orientações de escovação, brincadeiras diversas que envolveram a psicomotricidade, a ludicidade, criatividade e, a temática da edição deste ano, que era "Alimentar o presente é cuidar do futuro", como podemos ver nas imagens:

\footnotetext{
1 Este evento contempla uma das principais ações estratégicas da UNICEF de forma a garantir o cuidado com a criança até os 6 anos de idade, buscando garantir sobrevivência e direitos das crianças. A Prefeitura do Recife vem desenvolvendo desde 2015, atendendo a lei municipal 18.252/2016 que institui tal semana como forma de proteção à primeira infância com atividades que circundam tal tema, sendo sua quinta edição.

2 Para saber o trabalho inovador da CEC, desenvolvido desde 1995, na Comunidade de nova Caxangá, zona oeste de Recife, e que visa o desenvolver integral da criança de 3 a seis anos, além de apoio social e desenvolvimento sustentável da comunidade, Acesse o site: https://www.gabrielafeliz.org.br/.
} 



Fotos: Parte da Equipe Brinc@rte em Ação na CEC Gabriela Feliz Fonte: Equipe de Produção Audiovisual/UFRPE 
Nossas atividades levaram a questão do cuidado com a criança, não apenas com escovação dos dentes, mas de higiene pessoal nas atividades lúdicas e artísticas vivenciadas. Participaram das mesmas crianças de 4 e 5 anos, a equipe de monitoras, as gestoras do projeto e tivemos apoio da equipe escolar. Ao final da ação de arte e brincadeiras às crianças receberam um kit de escovação com escova e pasta dental para incentivo ao cuidado com os dentes.

A equipe do Projeto Brinc@rte ${ }^{3}$ teve um feedback positivo desta ação, tanto do ponto de vista da direção, professores e alunos ${ }^{4}$ que vivenciaram às ações ${ }^{5}$,estes últimos bastante engajados e demonstrando o quanto estavam felizes em participar das atividades. Como avaliação da ação pela equipe do projeto, vemos que ainda temos muito a caminhar para melhoria das futuras ações, mas que estamos desenvolvendo com este projeto ações primordiais de serem realizadas no âmbito do Brincar e da Arte como elementos que devem ser presentes no processo formativo da Educação Básica.

\section{CONSIDERAÇÕES FINAIS}

OBrinc@rte se coloca como um projeto de extensão da EAD/ UFRPE, que visa colocar a Arte e o Brincar como uma experiência de interdisciplinaridade em nosso modelo híbrido de educação, uma vez que busca aliar às diversas licenciaturas em prol de repensar o sentido do Brincar e da Arte na formação de nosso licenciandos, o que ao nosso olhar é primordial para que se tenha um reflexo de melhoria da qualidade da formação docente para a Educação Básica, papel da Universidade.

Além disto, o projeto busca qualificar os docentes, através de formação continuada, dialogando assim com a comunidade externa, tanto de escolas privadas ou públicas, quanto a comunidade local da

\footnotetext{
${ }^{3}$ Conheça o nosso projeto acessando o nosso instangram: @projetobrincarte e caso queira maiores informações mande para nosso email: projetobrincarte.ufrpe@gmail.com. Breve estaremos com site.

${ }^{4}$ Realizamos formulários de avaliação para a direção e professores, e para os alunos, fizemos uma ficha lúdica onde o aluno pintaria como se sentiu nas atividades desenvolvidas no projeto.

${ }^{5}$ Nossas ações no Centro Comunitário Gabriela Feliz bem como um pouco sobre o que é o projeto Brinc@rte, é possível de ser visto no vídeo: https://www.youtube.com/watch?v=ajbGEgNaT-E
} 
UAEADTec Recife, onde estamos localizados, bem como expandir às ações para os polos de apoio presencial.

Nossa primeira ação na $\mathrm{V}$ semana do Bêbe nos faz refletir que o resgate da brincadeira e da expressão artística em suas múltiplas linguagens se faz importante para a formação do aluno em seu sentido integral, como mesmo é afirmado e garantido pelas legislações brasileiras e nossa BNCC.

Brincar e Arte não são modos de preencher o tempo do aluno, mas são elementos que potencializam o processo de ensino e aprendizagem, e, por tal, precisam fazer parte do processo formativo do aluno na Educação Básica, e, deste modo, a universidade precisa atentar para trabalhar estes elementos na formação dos futuros docentes de nosso país.

\section{REFERÊNCIAS}

AGUIAR, João Valente: BASTOS, Nádia. Arte como Conceito e como Imagem: a redefinição da arte pela arte. Tempo Social: revista de Sociologia da USP, v.25, n 2, 2013. Disponível em: < http://www.scielo. br/pdf/ts/v25n2/a10v25n2.pdff> Acesso em: 28 de mai. de 2019.

ASSUMPÇÃO, Ismael. Interdisciplinaridade: uma tentativa de compreensão do fenômeno. In: FAZENDA, Ivani Catarina Arantes (Org). Práticas interdisciplinares na escola. São Paulo: Cortez, 2011, pp. 23-25. BARBOSA, Ana Mae; CUNHA, Fernanda Pereira da (Orgs.). Abordagem triangular no ensino das artes e culturas visuais. SP: Cortez, 2012. BORBA, A. M. O brincar como um modo de ser e estar no mundo. In: BRASIL, Ministério da Educação. Ensino fundamental de nove ano: orientação para a inclusão da criança de seis anos de idade, Brasília, 2006. Disponível em: <http://portal.mec.gov.br/seb/arquivos/pdf/Ensfund/ensfund9mais1.pdf> Acesso em: 28 de mai. de 2019.

. (Org.) Inquietações e mudanças no ensino da arte. São

Paulo: Cortez Editora, 2012.

BRASIL. Lei $n^{\circ}$ 9.394, de 20 de dezembro de 1996. Estabelece as Diretrizes e Bases da Educação Nacional. Diário Oficial da União, Brasília, 23 de novembro de 1996. Disponível em: <http://www.planalto.gov.br/ccivil_03/Leis/L9394.htm> Acesso em: 29 mai. de 2019. 
Base Nacional Comum Curricular (BNCC). Educação é a base. Brasília, MEC/CONSED/UNDIME, 2018. Disponível em: < http://basenacionalcomum.mec.gov.br/images/BNCC_EI_ EF_110518_versaofinal_site.pdf > Acesso em: 29 de mai. de 2019.

. Lei no 8.069/90 de 13 de julho de 1990. Dispõe sobre o Estatuto da Criança e do Adolescente e dá outras providências. Senado Federal, Brasília, 2011. Disponível em: < http://www.planalto.gov.br/ ccivil_03/leis/18069.htm> Acesso em: 29 de mai. de 2019.

. Constituição da República Federativa do Brasil de 1988. Brasília, DF: Senado Federal, 05 de dezembro de 1998. Disponível em: <http://www.planalto.gov.br/ccivil_03/constituicao/constituicao.htm>. Acesso em: 29 de mai. de 2019.

CONTI, Luciane de; SPERB, Tania Mara. O brinquedo de pré-escolares: um espaço de ressignificação cultural. Instituto de Psicologia da Universidade de Brasília. Psicologia: Teoria e Pesquisa, Jan-Abri 2001, vol.17, no.1, p.59-67. ISSN 0102-3772. Disponível em: <http:// www.scielo.br/pdf/ptp/v17n1/5406>. Acesso em: 04 de jun. de 2019. DELORS, Jacques. Educação: um tesouro a descobrir. Relatório para a UNESCO da Comissão Internacional sobre Educação para o século XXI. São Paulo: Cortez, 2012.

FAZENDA, Ivani. Interdisciplinaridade: história, teoria e pesquisa. 18 ed. Campinas: Papirus, 2011.

FORTUNA, T. R. Brincar, viver e aprender: Educação e Ludicidade no hospital. In: VIEGAS, Dráuzio. (org). Brinquedoteca hospitalar: Isto é humanização. 2a ed.Rio de Janeiro: Wak, 2007.

FREIRE, Paulo. Pedagogia da autonomia: saberes necessários à prática docente. 43. ed. São Paulo: Paz e terra, 1997.

KISHIMOTO, Tizuko Morchida. Jogos infantis: o jogo, a criança e a educação. 17. ed. Rio de Janeiro: Editora Vozes, 2012.

ONU. Declaração Universal dos Direitos das Crianças. Adotada pela Assembléia das Nações Unidas de 20 de novembro de 1959. Disponível em: < http://www.direitoshumanos.usp.br/index.php/Crian\%C3\%A7a/ declaracao-dos-direitos-da-crianca.html>. Acesso em: 01 jun. 2019.

MORAN, José Manuel. Educação híbrida: um conceito-chave para a educação hoje. In: BACICH, Lilian; NETO, Adolfo Tanzi; TREVISSANI, Fernando de Melo (Orgs.). Ensino híbrido: personalização e 
tecnologia na educação. Porto Alegre: Penso, 2015.

PIAGET, Jean. A formação do símbolo na criança: imitação, jogo, sonho e imaginação. 4. ed. Editora: LTC, 2010.

SEVERINO, Antônio Joaquim. Metodologia do trabalho científico. 24 ed. rev. e atual.. São Paulo: Cortez, 2017.

UNICEF. Convenção sobre os Direitos das Crianças. Adotada pela Assembleia Geral da ONU em 20 de novembro de 1989. Disponível em: <https://www.unicef.org/brazil/convencao-sobre-os-direitos-da-crianca >. Acesso em: 04 jun. 2019.

VYGOTSKY, Lev. S. A formação social da mente: o desenvolvimento dos processos psicológicos superiores. Organizadores Michael Cole et al. Tradução José C. Neto, Luís S. M. Barreto, Solange C. Afeche. 7. ed. São Paulo: Martins Fontes, 2015. (Psicologia e Educação). ZABALA, Antoni. A prática educativa: como ensinar. Tradução Ernani F. da F. Rosa. Porto Alegre: Penso, 2014. 


\section{APLICAÇÕES DA INTELIGÊNCIA ARTIFICIAL NA RESOLUÇÃO DE PROBLEMAS CLÁSSICOS DA EDUCAÇÃO A DISTÂNCIA}

Jéssica Ester Frutuoso de Souza Kátia Cilene da Silva Danniel Cavalcante Lopes Marcos Evandro Cintra

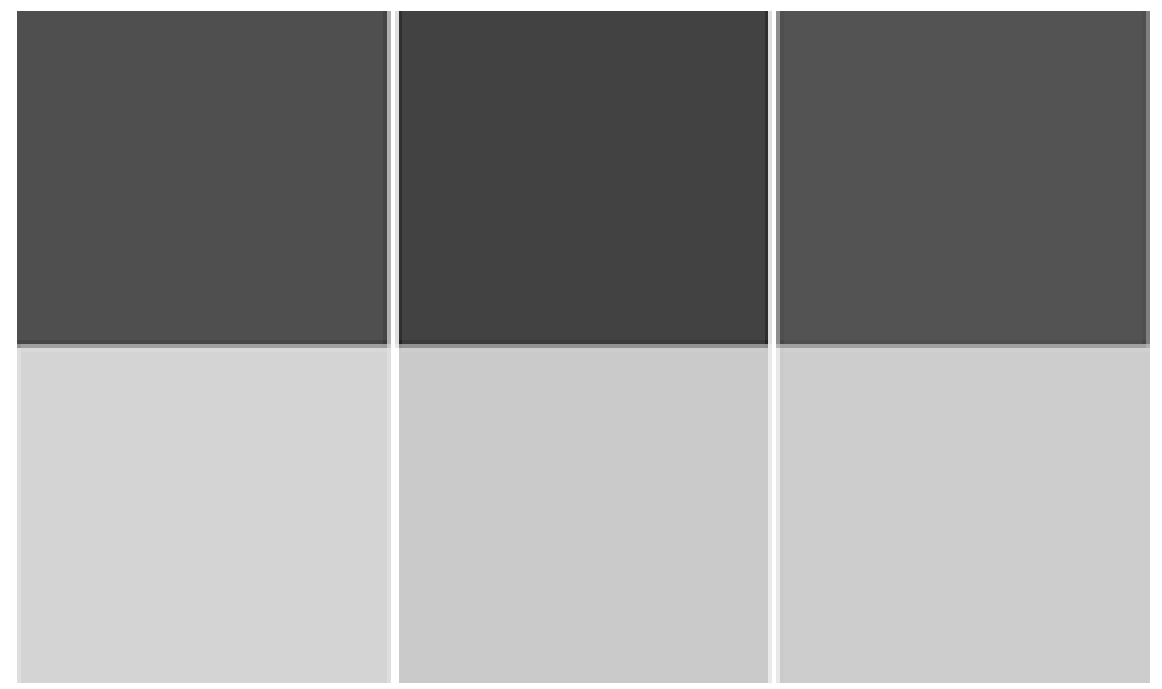




\section{INTRODUÇÃO}

A ascensão tecnológica dentro de um contexto de tecnologias digitais de redes possibilitou, por meio da internet, a criação de um novo ambiente de interação social capaz de relacionar indivíduos com interesses comuns, promovendo por meio da contribuição coletiva o compartilhamento eficaz de conteúdos e informações. No entanto, foi a popularização aliada a acessibilidade aos instrumentos de acesso a essa rede virtual que permitiu que essas tecnologias passassem a integrar o cotidiano de uma grande parcela de pessoas. Essa disseminação do acesso abriu portas para que um novo cenário educacional viesse a ressignificar o então modelo de ensino-aprendizagem.

Buscando beneficiar-se do que há de novo em termos de tecnologias digitais, a área de pesquisa em tecnologias educacionais têm estado cada vez mais atuante, no propósito de melhorar os recursos digitais voltados ao ensino. Um exemplo disso é o uso da Inteligência Artificial (IA), que tem potencializado os avanços nos ambientes educacionais. Rossi (2016) aponta a existência de diversas técnicas da IA em aplicações que reúnem a díade pedagogia-tecnologia, como por exemplo, o uso de agentes artificiais, que atuam de forma a enriquecer as relações entre o conteúdo e os usuários do sistema. Feitosa (2011) traz a utilização de Algoritmos Genéticos e mineração de dados em Ambientes Virtuais de Aprendizagem (AVA) no desenvolvimento de um modelo computacional de combinação social.

É crescente o número de trabalhos no campo dos sistemas educacionais que vem fazendo o uso da IA; contudo, diante da gama de recursos da IA e considerando-se o desprovimento de estudos que contemplam uma análise sobre a utilização da IA em sistemas e/ou funcionalidades no âmbito da Educação a Distância (EaD), este trabalho propõe a obtenção de informações com o intuito de se conhecer acerca do que vem sendo utilizado em termos de IA nos sistemas voltados para a $\mathrm{EaD}$, bem como propor sugestões de aplicações a serem desenvolvidas posteriormente. O método do presente estudo, dar-se-á por meio de pesquisa bibliográfica através da revisão de literatura em teses, dissertações e artigos publicados em periódicos científicos. 
A presente obra focou em publicações em português devido ao escopo do trabalho e para tornar o mesmo factível. Para que tal restrição não trouxesse prejuízos para os resultados obtidos, foi realizada uma pesquisa mais ampla em artigos em português e inglês que tratam dos principais desafios da $\mathrm{EaD}$. Desta pesquisa mais ampla, formam extraídas as abordagens baseadas em IA mais presentes para atacar os desafios da EaD. E com estas abordagens conhecidas, foi possível concentrar a pesquisa bibliográficas em dissertações de mestrado e teses de doutorados em português recentes, que, por sua vez, incluem considerável número de referências.

Neste contexto, o presente trabalho objetiva apresentar possibilidades de utilização da IA de forma específica na $\mathrm{EaD}$, visando uma melhor eficiência ao processo de ensino/aprendizado, através da revisão de literatura em teses, dissertações e artigos científicos da área, para identificar possíveis aplicações.

\section{REFERENCIAL TEÓRICO}

Nesta Seção são apresentados os principais conceitos sobre o Ensino a Distância e seus desafios, os Ambientes Virtuais de Aprendizagem (AVAs) e de Inteligência Artificial, incluindo as técnicas descritas neste trabalho.

\subsection{Ensino a Distância}

Diante do impacto da disseminação do acesso às tecnologias, principalmente as digitais, a EaD, outrora caracterizada por um sistema de correspondência pelo qual eram realizadas a troca de materiais físicos, agora se manifesta em um plano virtual, tornando-se ainda mais viável, por meio do apoio de softwares aplicativos. Essa viabilidade na $\mathrm{EaD}$, que data do começo da década de 90, transformou o ambiente da sala de aula, possibilitando que a díade professor-aluno pudesse interagir de forma assíncrona em relação ao tempo e espaço.

Para BICA (2000, apud Lazzarotto, 2010) a EaD tem por objetivo o desenvolvimento de ambientes e de metodologias que propiciam o aprendizado remoto, ou seja, que um ou mais alunos possam vivenciar 
experiências de aprendizagem em locais fisicamente distintos daqueles ambientes nos quais os recursos instrucionais se encontram.

Já Souza, et al. (2013) aponta a definição de Educação à Distância nos termos da Legislação Brasileira onde a EaD é caracterizada como a modalidade educacional na qual a "mediação didático-pedagógica nos processos de ensino e aprendizagem ocorre com a utilização de meios e tecnologias de informação e comunicação, com estudantes e professores desenvolvendo atividades educativas em lugares ou tempos diversos"(Art. 1), organizadas segundo metodologia, gestão e sistemas de avaliação com características próprias (BRASIL, 2005).

Alves (2011, apud, SEMENSATO et al., 2015) conceitua a $\mathrm{EaD}$ como uma modalidade de educação efetivada através do uso de tecnologias da informação e comunicação, na qual professores e alunos estão separados fisicamente, seja no espaço ou no tempo. No entanto, SEMENSATO (2015), discute a definição de EaD, expondo resultados de um levantamento realizado por ALVES (2011), que revela a existência de variação de concepções no que diz respeito ao que vem a ser a EaD. Ele relata que diferentes autores enfatizam características distintas em seu conceito de Ensino a Distância. As ênfases incluem, definição de $\mathrm{EaD}$ como sendo uma forma de estudo; como sendo as ações do professor e a comunicação deste com os alunos; ou também como sendo a separação física e uso de tecnologias de comunicação.

SEMENSATO et al (2015) descreve que até a ideia de que a EaD seja uma concepção ou modalidade educacional, é discutível. Pois, de acordo com o autor, seria mais esclarecedor o uso da ideia de "forma educacional", seja esta, presencial ou à distância, pois o termo modalidade, pode confundir com especificidades educacionais, tais como Educação de Jovens e Adultos (EJA), Educação Profissional, Educação Especial, Educação Indígena, consolidadas como modalidades educacionais. Tamanha imprecisão, segundo o autor, trazem à reflexão, a existência de normas legais que chegam a dizer que $\mathrm{EaD}$ é uma modalidade educacional que poderá ser aplicada a diversos níveis e modalidades de ensino. 


\subsection{Principais desafios relacionados os Ensino a Distância}

Entre os grandes desafios enfrentados pela Educação a Distância, podemos citar a evasão, a retenção, a falta de sentimento de pertencimento do aluno ao curso/instituição e o engajamento do aluno. Estes desafios são descritos a seguir.

\subsubsection{Evasão}

Entre os temas de grande relevância no que diz respeito à educação em um cenário de políticas públicas, encontramos a problemática da evasão escolar, sendo esta, um dos temas mais discutidos na educação (QUEIROGA, 2017). De acordo com QUEIROGA (2017), o conceito de evasão escolar define-se quando o aluno toma a decisão de se ausentar das aulas, caracterizando o abandono da escola durante o período letivo. $\mathrm{O}$ autor ainda define a evasão como um processo gradativo, que muitas vezes ocorre de maneira silenciosa e despercebida. Embora a EaD tenha possibilitado uma melhor difusão do conhecimento e democratização da informação como aponta SOUZA (2013), a reprodução do ambiente escolar no ambiente virtual também trouxe consigo os reais desafios enfrentados nos ambientes físicos, o que nos permite afirmar que a evasão também é um fato dentro do contexto $\mathrm{EaD}$.

Em relação a EaD, a definição de evasão se torna mais complexa, visto que não existe uma contagem de presença às aulas, como no ensino tradicional. De fato, em geral são consideradas questões como o número de acesso ao AVA, download de materiais como vídeos e apostilas, participação de fóruns, entre tantos outros parâmetros que geralmente são extraídos de logs de acesso automaticamente do AVA adotado.

\subsubsection{Retenção}

A questão da retenção do estudante de $\mathrm{EaD}$ está relacionada à dificuldade na avaliação e acompanhamento do desenvolvimento do aluno de acordo com o modelo a distância. Alguns autores apresentam a retenção como a solução para evasão, porém o que precisaria 
ser discutido é o aumento da taxa de sucesso/conclusão de curso, e não a retenção do aluno no curso, aumento seu tempo para conclusão. Isto se deve ao fato de que a complexidade de alguns conteúdos e o baixo repertório de estratégias didáticas utilizadas pelos professores faz com que os índices de reprovação em determinadas disciplinas fazendo com que os alunos não consigam progredir no curso, ficando retidos.

\subsubsection{Senso de Pertencimento do Aluno}

Este assunto também é de grande interesse para a $\mathrm{EaD}$ e está diretamente relacionado ao fato de não haver um relacionamento pessoal físico entre aluno e instituição de ensino. Por exemplo, no ensino tradicional, quanto mais ativo um aluno é na vida da instituição, como representante de turma, membro de um grêmio ou associação de alunos, ao participar de eventos esportivos ou culturais, o aluno cria e fortalece sua relação com a própria instituição.

\subsubsection{Engajamento do aluno}

O engajamento do aluno se dá quando ele desenvolve atividades relacionadas aos seus estudos e que objetivam seu aprendizado. Tais atividades incluem, por exemplo, participar de grupos de estudos, frequentar bibliotecas, usar monitorias, ter acesso aos professores fora dos horários de aula.

Já no contexto da $\mathrm{EaD}$, é preciso adotar processos e ferramentas que simulem ou permitam tais situações.

\subsection{Os ambientes virtuais de aprendizagem}

Delano (2013, apud QUEIROGA, 2017) cita um dos grandes benefícios que a $\mathrm{EaD}$ no contexto virtual trouxe; alcançar o público residente nas regiões periféricas aos grandes centros universitários, público este que de uma forma geral, tende a ficar isolado dos programas 
de graduação e cursos técnicos profissionalizantes. Perante esse alcance, que aboliu a barreira geográfica, tornou-se possível a expansão do acesso à educação; e com a função de intermediar a relação aluno-professor em uma plataforma Web, entraram em cena os AVAs.

Moreira (2017) elucida que foi o trabalho de grandes Instituições de Ensino no mundo, que tinham como objetivos buscar novas formas de reunir recursos de interação com páginas de conteúdos criadas por professores, bem como o armazenamento de atividades e aprendizagens realizadas pelos alunos, que concebeu o conceito de Virtual Learning Environments (VLEs) ou AVA, que também são denominados na literatura como Ambientes de Aprendizagem Online, Sistemas Gerenciadores de EaD, Software de Aprendizagem Colaborativa ou Sistemas Gerenciadores de Conteúdo e Aprendizagem na Web.

Os AVA são desenvolvidos com o intuito de auxiliar professores e tutores no processo de criação, gerenciamento e disponibilização de conteúdos e materiais complementares ofertados aos alunos. Através destes ambientes, também é possível fazer o acompanhamento de todo o processo de aprendizagem do aluno, colhendo-se por meio de suas interações, dados que representam seu desempenho no decorrer de sua jornada acadêmica. Seu objetivo principal é conduzir o processo de aprendizagem na Web, utilizando-se de interfaces que viabilizem a construção e utilização de seus recursos.

Moreira (2017) aponta os AVAs como ferramentas de gestão do conhecimento que são utilizadas para incentivar a aprendizagem do aluno, permitindo maior flexibilidade para o acesso ao material didático, possibilitando que as discussões entre os autores envolvidos ultrapassem o limite do espaço e tempo. Desta forma, os AVAs são considerados ferramentas fundamentais para que o processo de $\mathrm{EaD}$ ocorra.

Queiroga (2017) define AVA como o "local virtual" onde os cursos na modalidade a distância, ou semipresenciais, normalmente acontecem. Ele os descreve como ambientes que utilizam plataformas especialmente planejadas para abrigar cursos.

Os AVA ou ainda Ambientes Virtuais de Ensino e Aprendizagem (AVEA) também podem ser definidos como ambientes onde se realizam cursos online, onde a definição de cursos online consiste naqueles em que no mínimo $80 \%$ do conteúdo educacional é transmitido via AVEA, assim relata Allen e Seaman (2016, apud 
MORAIS, 2018). É importante destacar a diversidade de sistemas encontrados na literatura científica e a relevância dos Massive Open Online Course (MOOC) e das Universidades Abertas para tal popularização (MORAIS, 2018).

Grande parte dos AVEAs são compostos por uma estrutura que se organiza em módulos, com a finalidade de facilitar o processo de ensino-aprendizagem. Tais módulos contém atividades e recursos pedagógicos direcionados a um subgrupo temático do curso. Entre os principais recursos pedagógicos, destacam-se: fóruns de discussão, bate-papos, envios de arquivos, questionários, wikis ${ }^{1}$ e objetos de aprendizagem. A multidimensionalidade dos recursos pedagógicos possui o intuito de melhor entender as interações dos alunos (MORAIS, 2018).

Entre os temas de grande relevância no que diz respeito à educação em um cenário de políticas públicas, encontramos a problemática da evasão escolar, sendo esta, um dos temas mais discutidos na educação (QUEIROGA, 2017). De acordo com EYNG et al. (2013, apud QUEIROGA, 2017) o conceito de evasão escolar define-se quando o aluno toma a decisão de se ausentar das aulas, caracterizando o abandono da escola durante o período letivo. $\mathrm{O}$ autor ainda define a evasão como um processo gradativo, que muitas vezes ocorre de maneira silenciosa e despercebida. Embora a EaD tenha possibilitado uma melhor difusão do conhecimento e democratização da informação como aponta Maia (2017, apud SOUZA et al. 2013), a reprodução do ambiente escolar no ambiente virtual também trouxe consigo os reais desafios enfrentados nos ambientes físicos, o que nos ermite afirmar que a evasão também é um fato dentro do contexto EaD.

\subsection{A inteligência artificial}

A problemática da evasão se configura como um grande desafio no campo da EaD. Se por um lado, os ambientes virtuais se mos-

\footnotetext{
${ }^{1}$ Wiki é um tipo de programa de computador que permite criar, editar e hiperligar páginas da internet de forma ágil e colaborativa. Em outras palavras, é uma ferramenta que permite que pessoas editem, conectem e compartilhem colaborativamente seus documentos eletrônicos em rede. INUZUKA, M. A. Uso educativo do wiki: Um estudo na Faculdade de Educação da Universidade de Brasília. Trabalho Final (Mestrado Profissional em Tecnologias da Informação e Comunicação na Formação em EAD. 2008, UFC/UNOPAR, Brasília.
} 
tram eficazes na transmissão de conteúdos, por outro, não impedem a ocorrência do fenômeno da evasão. Isto posto, a necessidade de se ter sistemas de software cada vez mais eficientes, torna-se um objetivo na tentativa de melhorar a qualidade do ensino dentro desses ambientes virtuais. Nesse sentido, a IA tem se exercido como ponto chave na evolução desses sistemas que possuem como foco, o ensino e aprendizagem.

Entretanto, o que é exatamente IA? Em sua obra, Rosa (2011) aponta a definição exata desse termo como sendo motivo de discussão entre os pesquisadores da área. “Definir 'Artificial' é relativamente simples. 'Artificial' é tudo o que é feito pelo homem. E 'inteligência'? É bem mais complicado". Para o autor, uma definição bastante esclarecedora para IA é dada por Rich (1994) que afirma que a IA é o estudo de como fazer computadores realizarem tarefas as quais, até o momento, os homens fazem melhor. Segue a explicação do autor, denotando fazer parte da IA, tarefas relacionadas com o processo simbólico, reconhecimento de imagens e tudo que envolve aprendizado, sendo

Um computador convencional é capaz de realizar cálculos extremamente complexos que se realizados por um homem poderiam levar dezenas de anos, mas, no entanto, não é capaz de distinguir uma cadeira de metal de uma de madeira, coisa que até uma criança de três anos é capaz de fazer. Com base nisso, conclui-se que a IA tem por objetivo implementar numa máquina, a possibilidade de realizar tarefas que uma criança é capaz de realizar, mas o mais poderoso dos supercomputadores ainda não (RICH, 1994, p. 73).

Neste estudo, adotamos a perspectiva de Russel e Norvig (2013) veem a IA como um enorme campo que busca, além de compreender como pensam os seres humanos, criar entidades dotadas de inteligência. Os autores enfatizam o surgimento recente desse campo de conhecimento nas ciências e engenharia, atribuindo esse surgimento ao período que data do pós Segunda Guerra, sendo o ano de 1956, o ano em que culminou o termo IA. Eles complementam que a IA abrange uma variedade de subcampos, que vão do geral, que compreende a aprendizagem e a percepção, até tarefas específicas como jogos de xadrez, demonstração de teoremas matemáticos, criação de poesia, direção de um carro em estrada movimentada e diagnóstico 
de doenças. A IA é relevante para qualquer tarefa intelectual; é verdadeiramente um campo universal, afirmam os autores. Eles trazem ainda em uma visão geral, a ideia de agente inteligente como tema unificador no universo da IA. Para eles, a IA também pode ser definida como o estudo de agentes que recebem percepções do ambiente e executam ações.

Kerckhove (2003, apud QUEIROGA, 2017) entende a IA como uma ciência que estuda o fenômeno da Inteligência e o ramo da engenharia que constrói instrumentos para apoiar a inteligência humana, seja por meio de mecanismos ou de softwares. Ele diz ainda que, a aplicação da IA nos AVA representou uma evolução em importantes aspectos da $\mathrm{EaD}$, tais como: a facilidade de uso, interação com o usuário, disponibilidade de feedback para o tutor, e a diminuição de encontros presenciais.

Giraffa (1998, apud QUEIROGA, 2018) aponta para o uso das técnicas de IA, a fim de prover sistemas computacionais de ensino, com capacidade de adaptação ao contexto e personalização do ambiente de acordo com as características dos aprendizes, além de permitir um alto grau de interatividade entre o ambiente e os usuários e um controle maior das sessões de aprendizagem em ambientes multiusuários. Em outras palavras, pode-se enfatizar que a "introdução das técnicas de IA nesse ambiente, é de grande relevância, pois fornece mecanismos de modelagem tanto do processo de ensino, quanto do estado cognitivo do estudante" (BICA 2000, apud LAZZAROTTO, 2010).

A seguir, são apresentados os principais conceitos e abordagens de IA encontrados no contexto da $\mathrm{EaD}$. A aplicação deles é discutida na próxima seção.

\subsubsection{Agentes Inteligentes}

Os agentes inteligentes são geralmente caracterizados por tomarem uma decisão otimizada em face de uma situação. No contexto da computação e da IA, os agentes inteligentes são aplicações de software que tomam decisões baseadas em entradas. O conhecimento do domínio é armazenado em forma de bases de regras ou pelo uso de 
heurísticas. Quando uma mesma aplicação contém múltiplos agentes, é geralmente denominada multiagentes.

Rossi (2016) explica que Sistemas Tutores Inteligente (STI's) é a denominação para Sistemas Multiagentes com finalidade pedagógica; e seguem uma alusão às salas de aula tradicionais, onde os alunos e professores assumem respectivamente, o papel de agentes aprendizes e agentes tutores. $\mathrm{O}$ autor destaca também as vantagens do uso dos agentes inteligentes em um contexto de sistemas educacionais, ele relata que o fato do conhecimento ter a possibilidade de ser distribuído entre vários "tutores" (agentes), cada um com suas crenças, desejos, intenções, emoções, e planos de ação; cria maiores oportunidades de variar técnicas pedagógicas, pois o aprendiz interage de forma mais flexível com o tutor, e também poderá passar ao tutor, conhecimentos que serão compartilhados com os demais aprendizes. Ele também acrescenta que a estrutura dos sistemas multiagentes facilita a adição de novos agentes, uma vez que cada agente consiste em um módulo único e independente do outro. "Ambientes de ensino baseado em arquiteturas multiagente possibilitam suportar o desenvolvimento de sistemas de forma mais robusta, mais rápida e com menores custos" (ROSSI, 2016, p. 57).

Kose (2015, apud SEMENSATO et al., 2015) aponta o uso dos Agente Inteligentes, enfatizando que estes simulam o comportamento humano para resolver problemas. $\mathrm{O}$ autor cita também que há na $\mathrm{EaD}$ diversas aplicabilidades da IA, a exemplo do design de ferramentas para leituras online e desenvolvimento de soluções inteligentes.

\subsubsection{Aprendizado de máquina}

O aprendizado de máquina é uma área da IA que foca na automação da aquisição do conhecimento com base em dados, ou exemplos, de um determinado domínio. O aprendizado de máquina contém três tarefas básicas:

a) Modelos Preditivos: são modelos que classificam padrões com base em conhecimento prévio. Por exemplo, classificar uma pessoa em doente ou sadia. As principais técnicas de IA usadas são os sis- 
temas baseados em regras, as árvores de decisão, os sistemas fuzzy, algoritmos genéticos, redes neurais, entre outros.

b) Agrupamentos: são técnicas que permitem agrupar objetos de acordo com determinadas medidas de similaridade gerais. Por exemplo, distribuir 100 livros em 5 grupos distintos, de acordo com a similaridade entre eles. $\mathrm{O}$ algoritmo K-médias é o mais conhecido para essa tarefa.

c) Regras de Associação: a tarefa básica aqui é encontrar padrões entre conjuntos de objetos. Por exemplo, é comum obtermos sugestões de filmes ou livros quando usamos sistemas na Internet. As sugestões são feitas com base na análise de quais filmes geralmente são comprados ou assistidos em conjunto. Um exemplo clássico do poder das regras de associação é a da descoberta de que clientes de supermercado que compravam fraldas também compravam cerveja. A descoberta foi feita com a análise de milhares de cupons de compras de um supermercado. A explicação para tal é simples, famílias que têm filhos pequenos geralmente não saem para beber em bares, assim, compram cerveja. Tal descoberta foi empregada pela rede de supermercados para colocar cervejas próximas das seções de fraldas para aumentar as vendas.

\subsubsection{Aprendizado por reforço}

O aprendizado por reforço é uma técnica baseada na avaliação das ações de um agente e suas consequências. Cada vez que a ação tomada, entre um conjunto de ações, leve a uma aproximação do objetivo, tal ação recebe um incremento na sua pontuação. De forma similar, ações que afastem o agente do objetivo recebem redução na pontuação.

Assim, com o passar do tempo, o agente tende a encontrar as melhores soluções.

\subsubsection{Chatbots}

Chatbot (ou chatterbot) é um programa de computador que tenta simular um ser humano na conversação com as pessoas. $\mathrm{O}$ ob- 
jetivo é responder as perguntas de tal forma que as pessoas tenham a impressão de conversar com outra pessoa e não com um programa de computador.

Esses programas são usados amplamente por empresas que trabalham na internet para auxiliar clientes, por exemplo. São os chamados assistentes virtuais que respondem a consultas que já foram feitas e respondidas anteriormente. Em geral, caso o assistente virtual não consiga auxiliar o cliente, um humano assume a comunicação.

\subsubsection{Data mining, Learning analytics e Ontologias}

Estas são duas áreas com definições e objetivos similares. Ambas se baseiam na análise de dados, no contexto deste trabalho, dados educacionais, para extrair conhecimento do processo de ensino e aprendizado e, assim, possibilitar melhoras (MOISSA, 2015).

Data Mining (DM), ou Mineração de Dados, usa técnicas de $\mathrm{AM}$, em especial agrupamentos e classificação, e a técnicas que se baseiam em estatística. Já Learning Analytics (LA), geralmente usa as mesmas técnicas associadas a técnicas de visualização da informação para análise dos resultados obtidos. Outra área de pesquisa da LA é a análise de redes sociais.

As ontologias, por sua vez, servem para modelar dados que representam um conjunto de conceitos de um domínio e os relacionamentos entre esses conceitos. Assim, é uma técnica que é empregada na Mineração de Dados e Learning Analytics.

\subsubsection{Jogos}

Os jogos, ou jogos sérios, são sistemas computacionais desenvolvidos de forma a permitir a interação entre jogadores para transmitir conhecimento. São amplamente usados para treinamento e possuem a vantagem do caráter lúdico dos jogos. Outra vantagem do uso de jogos no contexto da educação é que o perfil dos alunos tem mudado, estão sempre próximos de smartphones e manter a atenção do aluno é um desafio constante para o professor. Assim, os jo- 
gos aproveitam a grande aceitação dos jovens, em especial, e o apelo competitivo característico para transmitir conhecimento de forma mais descontraída e motivadora do que as aulas tradicionais.

Jogos são usados desde treinamento profissional para saúde, publicidade, até engenharia da computação.

\subsubsection{Lógica Fuzzy}

A lógica Fuzzy e os sistemas fuzzy são baseados na teoria de conjuntos fuzzy proposta por Lofti Zadeh (Zadeh, 1965). Basicamente, os conjuntos fuzzy permitem modelar computacionalmente variáveis que são geralmente definidas com valores linguísticos. Por exemplo, é comum uma pessoa dizer que o dia está muito quente. Tais valores não são processados pelos sistemas computacionais. É preciso definir qual o intervalo para temperatura quente, e qual o ajuste a ser feito com o modificador muito. Depois de definido o intervalo, pode-se criar regras para serem processadas por sistemas computacionais. Por exemplo, se a temperatura está quente, então ajuste a potência do sistema de refrigeração para alta. Se o intervalo entre 30 e 35 graus Célsius define temperatura quente, 29,9 graus não dispara o sistema para que a potência seja ajustada para alta. A lógica usada no exemplo anterior é a dos conjuntos clássica. Um elemento pertence ou não a um conjunto. Os conjuntos fuzzy permitem que um elemento pertença a um conjunto com um determinado grau de pertinência. Isso permite que o mesmo elemento pertença a mais de um conjunto, possibilitando tratar de forma natural informações linguísticas, amplamente usada pelo ser humano.

Os sistemas fuzzy são usados para todas as tarefas de Aprendizado de Máquina.

\subsubsection{Sistemas Tutores Inteligentes}

O termo Sistema Tutores Inteligente (STI) é bastante abrangente e engloba qualquer programa de computador que contém alguma inteligência e que pode ser usado para o aprendizado. Assim, STIs podem usar qualquer uma das técnicas de IA descritas anteriormente 
para auxiliar no desenvolvimento e melhoria de AVAs. Por exemplo, um STI pode empregar Agentes Inteligentes para definir estratégias de ensino e conteúdo para alunos.

Para Santos Magalhães e D'Emery (2010, apud, SEMENTSATO et al., 2015) houve mudança no conteúdo dos ambientes educativos em EaD com inserção dos conceitos de (IA). Os Sistemas Tutores Inteligentes (STI's), por exemplo, tornaram-se muito populares. A característica principal desses aplicativos é sua capacidade de interagir com pessoas, percebendo as ações do aluno e a partir disso, atualiza sua base de conhecimentos.

\section{METODOLOGIA}

Esta pesquisa visa apresentar um levantamento das técnicas e conceitos de IA presentes nos sistemas de softwares educacionais voltados para o cenário da $\mathrm{EaD}$ nos últimos dez anos. Também será feita uma apresentação das mais diversas tendências nos mais diversos campos da IA, com o intuito de propor o advento de novas aplicações inteligentes que confiram melhor eficiência ao processo de ensino-aprendizado. Para tanto, a metodologia deste trabalho configura-se da seguinte forma: 1) Tipologia da pesquisa; 2) Etapas Metodológicas; 3) Objeto de Estudo; 4) Método de coleta de dados; e, 5) Técnicas de análise desses dados.

\subsection{Tipologia da Pesquisa}

O presente trabalho se classifica como uma pesquisa descritiva quali-quantitativa. Descritiva por fazer um levantamento sobre as diversas técnicas e paradigmas de IA que vêm sendo utilizados no período de 2009 à 2019, nos sistemas de software dedicados a EaD para, a partir destes dados, propor soluções futuras. Esta caracterização se embasa na compreensão de Ary, Jacobson e Razavish juntamente a Cook e Kenneth (1975, apud BEZERRA, 2014, p. 92) que afirmam que,

[...] a pesquisa descritiva serve para obtenção de informações relacionadas à situação atual de um fenômeno, envolvendo dados que descre- 
vem basicamente a forma como se dá uma determinada situação. Tais dados possibilitam que o pesquisador obtenha uma imagem presente, que serve de base para uma crítica ou tomada de decisão a respeito de uma situação específica.

Quanti-qualitativa por utilizar-se de métodos de revisão de literatura para realizar a coleta dos dados. Os dados quantitativos, foram agrupados com base na frequência das técnicas/paradigmas da IA; e os dados qualitativos, são provenientes da leitura de teses, dissertações e monografias. A escolha desses métodos é justificada pela compatibilidade ao tipo de estudo realizado.

A abordagem utilizada nesta pesquisa é a interpretativa, através da qual serão realizadas interpretações dos conteúdos obtidos por meio da leitura em teses, dissertações e monografias publicadas no período de tempo que compreende os anos de 2009 a 2018, cujas interpretações foram posteriormente categorizadas.

\subsection{Etapas Metodológicas}

Os passos que elucidam a construção deste trabalho estão dispostos cronologicamente nos seguintes etapas:

- Levantamento Bibliográfico dos referenciais teóricos relacionando os principais conceitos ligados a $\mathrm{EaD}$, AVA e IA.

- Levantamento Bibliográfico dos trabalhos desenvolvidos com o uso de técnicas/paradigmas da IA utilizados na EaD.

- Levantamento das tendências nas pesquisas sobre aplicação da IA na $\mathrm{EaD}$.

-Análise quantitativa e qualitativa dos dados.

- Indicação de possíveis aplicações a partir das tendências na IA e nas modalidades de software educativo, no contexto EaD.

- Comparativo dos resultados desta pesquisa com os de pesquisas correlatas.

- Contribuições, limites e possibilidades. 


\subsection{Objeto de Estudo}

O objeto de estudo do presente artigo restringe-se em identificar tendências na IA que possam ser aplicadas ao contexto da EaD.

\subsection{Método de Coleta de Dados}

Os dados desta pesquisa foram coletados por meio da realização de pesquisa bibliográfica em teses, dissertações e monografias, do Banco de Teses e Dissertações da CAPES, podendo ser classificados como fonte de referência.

\subsubsection{Fontes de Referência}

- Referencial teórico da área de Educação a Distância;

- Referencial teórico na área de IA;

- Publicações recentes (monografias, teses e dissertações defendidas no Brasil) a respeito de aplicações que fazem uso da IA no âmbito da $\mathrm{EaD}$;

- Publicações recentes (artigos de revistas científicas, monografias, teses e dissertações) sobre o uso contemporâneo da IA.

\subsection{Técnicas de Análise de Dados}

Os dados desta pesquisa foram analisados como mostrado abaixo:

- Os dados qualitativos foram organizados manualmente em documentos eletrônicos, com base nos princípios de análise de conteúdo.

- Os dados quantitativos foram tabulados de acordo com os princípios da análise estatística, utilizando o Microsoft Excel.

- A análise dos dados compreendeu as seguintes estratégias de análise: estatística, de conteúdo e documental. 


\section{ANÁLISE E DISCUSSÃO DOS RESULTADOS}

Nesta Seção são apresentadas e detalhadas as tarefas principais da proposta, assim como seus resultados.

\subsection{Levantamento bibliográfico para definição das técnicas prin- cipais de IA na EaD}

Após, foi feita o levantamento bibliográfico das técnicas de IA usadas como estratégias para lidar com os desafios da $\mathrm{EaD}$, previamente definidos, em obras em todos os idiomas.

O quadro 1 apresenta as técnicas encontradas na literatura para o problema da evasão, assim como o total de obras encontradas e a query usada para a busca.

\begin{tabular}{|c|c|c|}
\hline Problema & Técnicas Aplicadas & Palavras da pesquisa (147 referências encontradas) \\
\hline \multirow{11}{*}{ 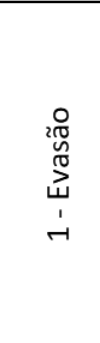 } & Agentes Inteligentes & \multirow{11}{*}{ "distance education" + "evasion" + "artificial intelligence } \\
\hline & Aprendizado por reforço & \\
\hline & Chatbots & \\
\hline & Data Mining & \\
\hline & lógica fuzzy & \\
\hline & Jogos & \\
\hline & Learning analytics & \\
\hline & Multi Agentes & \\
\hline & Redes neurais & \\
\hline & Regressão & \\
\hline & Sistemas tutores inteligentes & \\
\hline
\end{tabular}

Quadro 1 - Técnicas usadas para atacar a evasão na EaD.

Fonte: Dos Autores (2019)

O quadro 2 apresenta as técnicas encontradas na literatura para o problema da retenção, assim como o total de obras encontradas e a query usada para a busca.

\begin{tabular}{|c|c|c|}
\hline Problema & Técnicas Aplicadas & Palavras da pesquisa (1.420 referências encontradas) \\
\hline \multirow{7}{*}{ 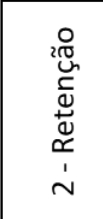 } & Aprendizado de máquina & \multirow{7}{*}{ "distance education" + "retention" + "artificial intelligence" } \\
\hline & Jogos & \\
\hline & Learning Analytics & \\
\hline & Mineração de Dados & \\
\hline & Multi-agentes & \\
\hline & Redes Neurais & \\
\hline & Sistemas tutores inteligentes & \\
\hline
\end{tabular}

Quadro 2 - Técnicas usadas para atacar a retenção na EaD.

Fonte: Dos Autores (2019) 
O quadro 3 apresenta as técnicas encontradas na literatura para o problema da conclusão, assim como o total de obras encontradas e a query usada para a busca.

\begin{tabular}{|c|l|c|}
\hline Problema & Técnicas Aplicadas & Palavras da pesquisa (122 referências encontradas) \\
\hline 3 & Aprendizado de máquina & \multirow{2}{*}{ distance education + "study progress" + "artificial intelligence" } \\
\cline { 2 - 2 } Conclusão & Learning Analytics & \\
\hline
\end{tabular}

Quadro 3 - Técnicas usadas para atacar a conclusão na EaD. Fonte: Dos Autores (2019)

O quadro 4 apresenta as técnicas encontradas na literatura para o problema do pertencimento, assim como o total de obras encontradas e a query usada para a busca.

\begin{tabular}{|c|c|c|}
\hline Problema & Técnicas Aplicadas & Palavras da pesquisa (757 referências encontradas) \\
\hline \multirow{5}{*}{ 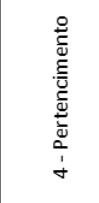 } & Aprendizado de Máquina & \multirow{5}{*}{ distance education + "belonging" + "artificial intelligence" } \\
\hline & Jogos & \\
\hline & Learning Analytics & \\
\hline & Ontologias & \\
\hline & Redes Neurais & \\
\hline
\end{tabular}

Quadro 4 - Técnicas usadas para atacar o senso de pertencimento na EaD. Fonte: Dos Autores (2019)

O quadro 5 apresenta as técnicas encontradas na literatura para o problema do engajamento, assim como o total de obras encontradas e a query usada para a busca.

\begin{tabular}{|c|c|c|}
\hline Problema & Técnicas Aplicadas & Palavras da pesquisa (923 referências encontradas) \\
\hline \multirow{4}{*}{ 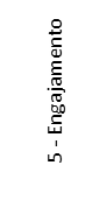 } & Agentes Inteligentes & \multirow{4}{*}{ distance education + "student engagement" + "artificial intelligence" } \\
\hline & Aprendizado de Máquina & \\
\hline & Jogos & \\
\hline & Learning Analytics & \\
\hline
\end{tabular}

Quadro 5 - Técnicas usadas para atacar o engajamento do aluno na EaD. Fonte: Dos Autores (2019) 


\subsection{Levantamento Bibliográfico dos trabalhos em português que usam as técnicas definidas na etapa anterior para atacar os princi- pais desafios da EaD com base na IA}

$\mathrm{O}$ uso da IA em aplicações na $\mathrm{EaD}$ se constitui um tema de caráter emergente e, por consequência, a quantidade de trabalhos desenvolvidos é pequena, principalmente no que diz respeito a estudos experimentais. Neste contexto, foi realizado um levantamento bibliográfico com foco em monografias, teses e dissertações, publicadas no período de 2009 à 2018, acerca do uso da IA no domínio da EaD, envolvendo todas as possíveis modalidades em AVA.

O levantamento bibliográfico em monografias, teses e dissertações da área totalizou 14 trabalhos relacionados às palavras-chaves: a) IA na EaD, IA em AVAs, Sistemas Tutores Inteligentes, Sistemas Multiagentes na EaD, Learning Analytics EaD, Mineração de dados na EaD. Destas, 4 são teses, 8 são dissertações e 1 é monografia. A seguir podemos observar o fenômeno de novas técnicas/abordagens da IA sendo inseridos no contexto da EaD.

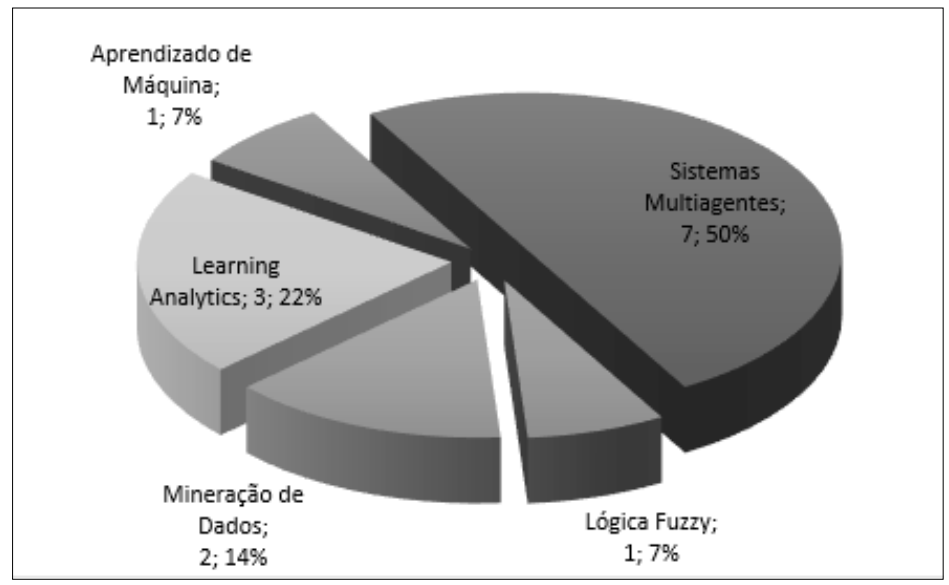

Gráfico 1 - Distribuição das abordagens de IA nos últimos dez anos Fonte: Dos Autores (2019)

No que se refere às técnicas/paradigmas abordados no levantamento das pesquisas, foi realizada a categorização apresentada no quadro 6. 


\begin{tabular}{l|c}
\multicolumn{1}{c|}{ Tema } & Pesquisas \\
\hline Sistemas Multiagentes/ Sistemas Tutores & 7 \\
\hline Lógica Fuzzy & 1 \\
\hline Mineração de Dados & 2 \\
\hline Learning Analytics & 3 \\
\hline Aprendizado de Máquina/Machine Learning & 1 \\
\hline Total & $\mathbf{1 4}$ \\
\hline
\end{tabular}

Quadro 6- Distribuição das abordagens da IA por pesquisas Fonte: Dos Autores (2019)

Observando-se a tabela 1, pode-se verificar que os Sistemas Tutores Inteligentes/Sistemas Multiagentes concentram a maior parte das pesquisas. Embora tenham sido utilizados ao longo dos anos, os STI's/SMA's vem perdendo espaço para novas tecnologias, tendo em vista os novos recursos da IA e sua adequação no tratamento das novas necessidades dos alunos EaD. Diante disso, técnicas como mineração de dados, Learning Analytics e Aprendizado de Máquinas indicam-se promissoras para melhorar a eficiência dos sistemas de ensino e aprendizado na $\mathrm{EaD}$, uma vez que são capazes de promover uma condução personalizada do aluno a partir da exploração de seus recursos.

Analisando-se a distribuição das pesquisas por ano pode-se verificar que de 2010 a 2015 houve pouca variação da quantidade de monografias, dissertações e teses sobre aplicações da IA na EaD, variando entre 0 e 1 pesquisa por ano. A partir de 2016 percebe-se um aumento na quantidade anual de pesquisas (gráfico 2), o que pode estar relacionado a uma nova fase de preocupação dos gestores e demais profissionais que atuam na $\mathrm{EaD}$, pois nos 10 primeiros anos de oferta de EaD no Brasil (2005 a 2015) as preocupações estavam voltadas para a viabilização dos requisitos mínimos para oferta de cursos nessa modalidade de ensino. Depois de 10 anos de aprendizado, os problemas passaram a se concentrar em: a) evasão; b) retenção; c) baixo percentual de sucesso/êxito (conclusão); d) baixo sentimento de pertença (quando o aluno se sente parte da instituição de ensino); e) baixo nível de engajamento com as atividades do curso e/ou disciplinas. 


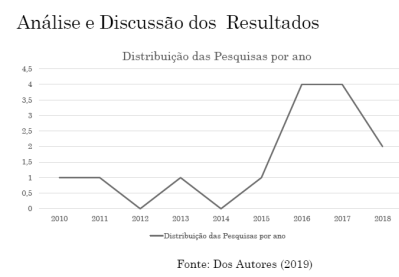

Gráfico 2 - Distribuição das pesquisas por ano Fonte: Dos Autores (2019)

Já quando as pesquisas encontradas são organizadas por técnica de IA aplicação na $\mathrm{EaD}$ (gráfico 3) pode-se verificar que até 2015 as duas técnicas que aparecem são Sistemas multiagentes e Mineração de dados. No entanto, a partir de 2016, além dessas duas técnicas, também passam a aparecer pesquisas utilizando Lógica Fuzzy, Learning Analytics e Aprendizado de máquina, o que pode indicar uma tentativa dos pesquisadores da área em diversificar as técnicas para a resolução de um número maior de problemas clássicos da $\mathrm{EaD}$.

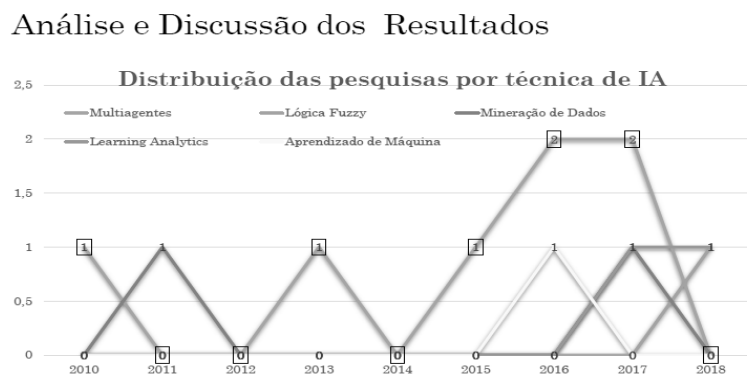

Gráfico 3 - Distribuição das pesquisas por técnica de IA Fonte: Dos Autores (2019)

A descrição detalhada dos trabalhos pesquisados, incluindo autor, ano de publicação, tipo de pesquisa e título, são apresentadas no Quadro 7. 
Quadro 7 - Trabalhos sobre aplicação da IA na EaD e ou em AVAs

\begin{tabular}{|c|c|c|c|}
\hline AUTOR & ANO & $\begin{array}{l}\text { TIPO DE } \\
\text { PESQUISA }\end{array}$ & TÍTULO \\
\hline MORAIS & 2018 & Tese & $\begin{array}{l}\text { Abordagem Avaliativa Multidimensio- } \\
\text { nal para Previsão da Evasão do Discente } \\
\text { em Cursos Online }\end{array}$ \\
\hline SILVA & 2018 & Tese & $\begin{array}{l}\text { Uma Abordagem de Learning Analytics } \\
\text { para a Autorregulação da Aprendizagem } \\
\text { de Estudantes em Sala de Aula Inverti- } \\
\text { da. }\end{array}$ \\
\hline BARBOSA & 2017 & Dissertação & $\begin{array}{l}\text { Exploring Learning Analytics Approaches } \\
\text { to Minimize Undergraduate Evasion }\end{array}$ \\
\hline MOREIRA & 2017 & Tese & $\begin{array}{l}\text { Um Modelo de Sistema AVA-SMA } \\
\text { Orientado à Legislação }\end{array}$ \\
\hline QUEIROGA & 2017 & Dissertação & $\begin{array}{l}\text { Geração de Modelos de Predição para } \\
\text { estudantes em risco de evasão em } \\
\text { cursos técnicos a distância utilizando } \\
\text { técnicas de mineração de dados. }\end{array}$ \\
\hline SANTANA & 2017 & Dissertação & $\begin{array}{l}\text { Geração de Ambientes Virtuais de Ensi- } \\
\text { no-Aprendizagem para Cursos Basea- } \\
\text { dos na Realização de Projetos }\end{array}$ \\
\hline FERREIRA & 2016 & Monografia & $\begin{array}{l}\text { Técnicas de Aprendizado de Máquina } \\
\text { aplicadas à identificação de perfis de } \\
\text { aprendizado em um ambiente real de } \\
\text { ensino. }\end{array}$ \\
\hline PAIVA & 2016 & Dissertação & $\begin{array}{l}\text { Melhoria na Convergência do Algorit- } \\
\text { mo Q-learning na Aplicação de Siste- } \\
\text { mas Tutores Inteligentes }\end{array}$ \\
\hline PORTAL & 2016 & Dissertação & $\begin{array}{l}\text { Estratégias Para Minimizar a Evasão e } \\
\text { Potencializar a permanência em EAD a } \\
\text { partir de Sistemas que utiliza Minera- } \\
\text { ção de Dados Educacionais e Learning } \\
\text { Analytics }\end{array}$ \\
\hline ROSSI & 2016 & Tese & $\begin{array}{l}\text { Infraestrutura Inteligente para o au- } \\
\text { mento da reusabilidade de objetos de } \\
\text { aprendizagem }\end{array}$ \\
\hline XAVIER & 2015 & Dissertação & $\begin{array}{l}\text { Um Sistema Multiagente de apoio à } \\
\text { Gestão de Cursos EAD em um ambien- } \\
\text { te virtual de aprendizagem }\end{array}$ \\
\hline
\end{tabular}




\begin{tabular}{c|l|l|l}
\hline $\begin{array}{c}\text { GALASFAS- } \\
\text { SI }\end{array}$ & 2013 & Dissertação & $\begin{array}{l}\text { Agente Pedagógico para medição do } \\
\text { processo de Ensino-Aprendizagem da } \\
\text { dedução natural na lógica proposicio- } \\
\text { nal. }\end{array}$ \\
\hline FEITOSA & 2011 & Dissertação & $\begin{array}{l}\text { Um Modelo Computacional de Com- } \\
\text { binação Social aplicado ao processo } \\
\text { de planejamento de orientadores em } \\
\text { Ambiente Virtuais de Aprendizado. }\end{array}$ \\
\hline $\begin{array}{c}\text { LAZZARO- } \\
\text { TTO }\end{array}$ & 2010 & Dissertação & $\begin{array}{l}\text { Sistemas Multiagentes na avaliação } \\
\text { pedagógica e na deteç̧ão do perfil cog- } \\
\text { nitivo dos alunos: proposta de modelo } \\
\text { para uso em ambientes de Ensino a } \\
\text { Distância. }\end{array}$ \\
\hline
\end{tabular}

Fonte: Dos Autores (2019)

Sobre as pesquisas contidas no Quadro 1, foram considerados tanto os casos descritivos como experimentais.

Moreira (2017) traz em seu trabalho, uma aplicação da IA em AVA com o uso de Sistemas Multiagentes (SMA). Afirma a autora, que atribuir IA em Ambientes Virtuais, é uma forma de procurar que esses ambientes tenham um bom desempenho e que seus recursos facilitem o processo de aprendizagem; Lazzarotto (2010), utiliza Sistemas Multiagentes para avaliar perfis cognitivos e avaliar pedagogicamente os alunos na EaD. Outras aplicabilidades multiagentes podem ser conferidas nos trabalhos de Xavier (2015), Santana (2017), Paiva (2016), Galafassi (2012) e Rossi (2016).

Barbosa (2017) faz abordagens com Learning Analytics no combate à evasão, enquanto Silva (2018) traz em sua tese, uma abordagem L.A para a autorregulação da aprendizagem de estudantes em sala de aula invertida.

Morais (2018) utiliza lógica fuzzy na abordagem avaliativa multidimensional para previsão de evasão dos alunos em cursos online.

Ferreira (2016) trabalha o aprendizado de máquina na identificação de perfis em um ambiente real de ensino.

Utilizando técnicas de Mineração de Dados, Queiroga (2017) traz em sua obra, modelos de predição para estudantes da EaD em risco de evasão. Ele relata acerca dos resultados satisfatórios que a 
aplicação de técnicas de predição da IA na modelagem de comportamento dos alunos EaD tem gerado. Destaca ainda o autor que a predição nos ambientes virtuais têm um caráter bifocal, podendo se utilizada para atuar na predição das notas dos alunos nas avaliações, ou ainda para prever o risco de evasão destes alunos. Já Feitosa (2011) utiliza as técnicas de mineração de dados em um modelo de combinação social para auxiliar no processo de planejamento de orientadores em AVA.

\section{CONSIDERAÇÕES FINAIS}

Com base nos objetivos traçados, pode-se afirmar que a presente pesquisa alcançou êxito ao que se propôs, trazendo um levantamento dos recursos de IA que foram utilizados ao longo dos dez últimos anos e observando a inserção de novas técnicas de IA no contexto da EaD, principalmente no que se refere às aplicações em AVA.

\subsection{Contribuições da pesquisa}

Através da revisão bibliográfica sobre aplicações da IA na EaD em teses, dissertações, monografias e artigos em periódicos publicados dos últimos 10 anos, foi possível identificar as pesquisas desenvolvidas sobre essa temática e realizar uma análise categórica dessas pesquisas segundo as técnicas de IA indicadas nas publicações.

Como principal contribuição do presente estudo, pode-se citar a identificação das novas tendências de aplicações da IA na EaD em seus mais diversos campos, bem como indicar possíveis novas aplicações a partir de técnicas da IA que possuem potencial para contribuir na resolução de alguns problemas clássicos da $\mathrm{EaD}$.

\subsection{Limitações da pesquisa}

Como principal dificuldade encontrada ao longo do estudo, pode-se citar a quantidade pequena de pesquisas sobre o tema formalmente publicadas, o que corrobora o caráter emergente do inves- 
timento em pesquisas sobre as possíveis aplicações da IA na EaD e, especialmente, nos AVAs.

Também é importante ressaltar que, mesmo as publicações que sinalizam em seu título sobre a apresentação de técnicas da IA aplicadas a EaD acabam por apresentar técnicas já conhecidas historicamente por serem "aplicáveis" na educação, como sistemas tutores inteligentes e agentes.

\subsection{Estudos futuros}

Como estudos futuros, pode-se utilizar as sinalizações aqui apresentadas como guias para a realização de pesquisas sobre as aplicações das técnicas da IA para promoção da acessibilidade em AVAs, para desenvolver e disponibilizar ambientes de simulação nos AVAs, que potencializem o aprendizado dos alunos, bem como aproveita a tendência do uso de jogos na educação para desenvolver e aplicar jogos inteligentes, que utilizem técnicas de IA, nos AVAs, tanto para potencializar o aprendizado como para aumentar o nível de engajamento dos alunos da $\mathrm{EaD}$, o que poderia influenciar tanto nas taxas de permanência (redução da evasão) como de êxito/sucesso (conclusão de curso).

Também pode-se citar como novas aplicações o uso de learning analytics e técnicas de data science para a realização de análises sobre os dados de perfil, comportamento e desempenho acadêmico dos alunos nos AVAs.

\section{REFERÊNCIAS}

BARBOSA, A. M. Exploring Learning Analytics A proaches to minimize undergraduate evasion. 2017. Dissertação (Mestrado em Ciência da Computação). Universidade Federal do Ceará, Fortaleza.

BEZERRA, V. G. Os professores de instrumentos e suas ações nas escolas parquet de Brasília: uma pesquisa descritiva. 2014. Dissertação (Mestrado em Educação Musical). Departamento de Música, Universidade de Brasília, Brasília. 
FEITOSA, D. L. Um modelo computacional de combinação social aplicado ao processo de planejamento de orientadores em ambientes virtuais de aprendizagem. 2011. Dissertação (Mestrado em Modelagem Computacional de Conhecimento). Instituto de Computação, Universidade Federal de Alagoas, Maceió.

FERREIRA, L. D. Técnicas de aprendizado de máquina aplicadas à identificação de perfis de aprendizado em um ambiente real de Ensino. 2016. Monografia (Qualificação de Mestrado em Ciências - Ciências da Computação e Matemática Computacional). Universidade de São Paulo, São Carlos.

GALAFASSI, F. F. P. Agente pedagógico para mediação do processo de ensino-aprendizagem da dedução naural na lógica. 2013. Dissertação. UNISINOS, São Leopoldo.

LAZZAROTTO. L. L. Sistemas multiagentes na avaliação pedagógica e na detecção do perfil cognitivo dos alunos: proposta de modelo para uso em ambientes de ensino a distância. 2010. Dissertação (Mestrado em Ciência da Computação). Universidade Federal de Viçosa, Viçosa. MORAIS, A. M. Abordagem avaliativa multidimensional para previsão da evasão do discente em cursos online. 2018. Tese (Doutorado em Ciência da Computação). Centro de Engenharia Elétrica e Informática, Universidade Federal de Campina Grande, Campina Grande.

MOREIRA, M. I. G. Um modelo de sistema AVA-SMA orientado à Legislação. 2017. Tese (Doutorado em Ciência da Computação). Instituto de Informática, Universidade Federal do Rio Grande do Sul, Porto Alegre.

PAIVA, E. O. Melhoria na convergência do Algoritmo Q-learning na aplicação de sistemas tutores inteligentes. 2016. Dissertação. Universidade Federal dos Vales do Jequitinhonha e Mucuri, Diamantina.

PORTAL, Cleber. Estratégias para minimizar a evasão e potencializar a permanência em EAD a partir de sistema que utiliza mineração de dados e learning analytics. 2016. Dissertação (Mestrado em Educação). UNISINOS, São Leopoldo.

QUEIROGA, E. M. Geração de modelos de predição para estudantes em risco de evasão em cursos técnicos a distância utilizando técnicas de mineração de dados. 2017. Dissertação (Mestrado em Ciência da Computação). Centro de Desenvolvimento Tecnológico, Universidade Federal de Pelotas, Pelotas. 
ROSA, J. L. G. Fundamentos da inteligência artificial. Rio de Janeiro: LTC, 2011. ISBN 978-85-216-0593-5.

ROSSI, L. H. L. Infraestrutura inteligente para o aumento da reusabilidade de objetos de aprendizagem. 2016. Tese (Doutorado em Ciência da Computação). Instituto de Informática, Universidade Federal do Rio Grande do Sul, Porto Alegre.

RUSSEL, S.; NORVIG, P. Inteligência artificial. Tradução de Regina Célia Simille. 3. ed. Rio de Janeiro: Elsevier, 2013.

SANTANA, A. O. Geração de ambientes virtuais de ensino-aprendizagem para cursos baseados na realização de projetos. 2017. Dissertação (Mestrado em Sistemas e Computação). Departamento de Informática e Matemática aplicada. Universidade Federal do Rio Grande do Norte, Natal.

SANTOS, C. F. G. Optical character recognition using deep learning. 2018. Dissertação (Mestrado em Ciência da Computação). UNESP, São José do Rio Preto.

SEMENSATO, M. R.; FRANCELINO, L. A.; MALTA, L. S. Revista Cesuca Virtual: Conhecimento sem fronteiras, Cachoeirinha, RS. v.2, n.4, Ago/2015.

SILVA, J. C. S. Uma abordagem de learning analytics para a autorregulação da aprendizagem de estudantes em sala de aula invertida. 2018. Tese (Doutorado em Ciência da Computação). Universidade Federal de Pernambuco, Recife.

SOUZA. D.L. et al. Redes na educação a distância: uma análise estrutural do sistema UAB em Minas Gerais, Belo Horizonte, Revista Pretexto, v.15, p.84-98, 2014. Disponível em: <http://www.fumec.br/ revistas/pretexto/article/view/1700>. Acesso em: ago.2019.

XAVIER. N. B. Um sistema multiagente de apoio a gestão de cursos EAD em ambiente virtual de aprendizagem. 2015. Dissertação (Mestrado em Informática). Universidade Federal do Amazonas, Manaus. 
O ENSINO HÍBRIDO POTENCIALIZANDO O USO DE TICS PARA ALÉM DOS MUROS DA ESCOLA

José Wilson Cavalcante Júnior

Kátia Cilene da Silva

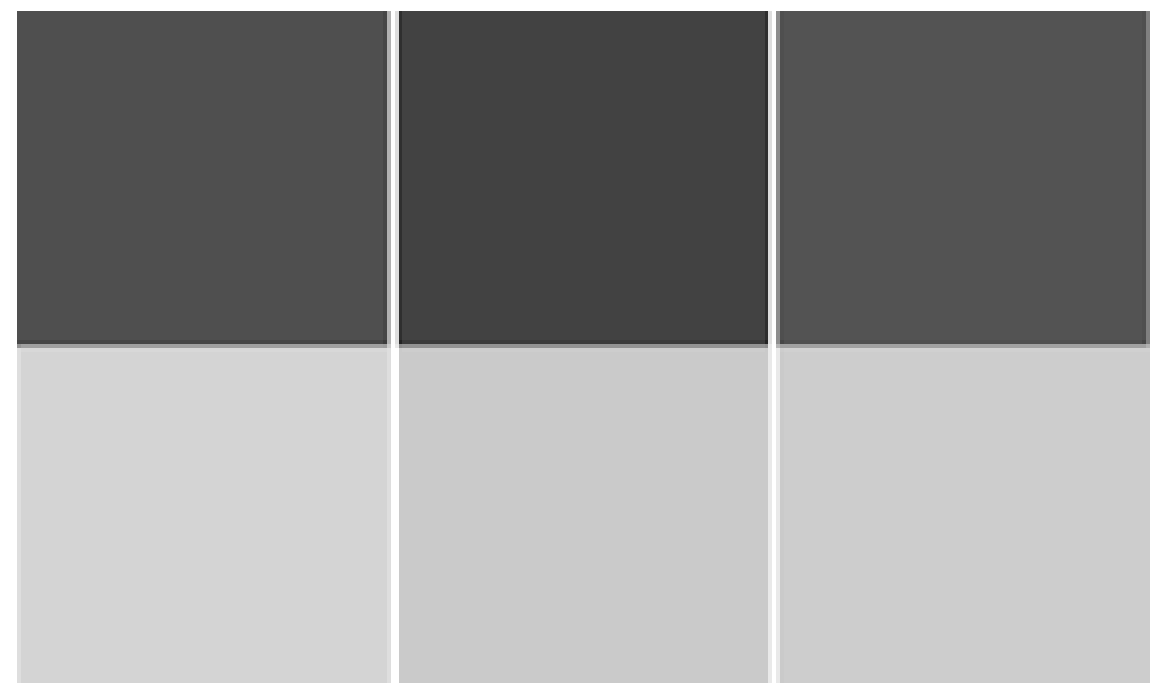




\section{INTRODUÇÃO}

As tecnologias da informação e comunicação (TICs) estão cada vez mais em alta, o que possibilita a melhor e maior interação entre os meios da sociedade. No âmbito educacional, o computador é uma das principais ferramentas, contribui para o docente na sua tarefa de transmitir o conhecimento e torna o ensino mais dinâmico e criativo. Além disso, o contato com a tecnologia favorece a motivação dos alunos durante as aulas, contribuindo para consolidar de forma efetiva o aprendizado.

Podemos dizer que o computador não é uma ferramenta que ensina, mas é um dispositivo que o aluno produz algo, e, com isso, o aprendizado ocorre devido o discente está pondo em prática uma tarefa através do computador.

Segundo Almeida e Valente (2011), o computador colabora na construção do conhecimento, uma vez que propicia novos conteúdos e estratégias para incrementar o nível de conhecimento adquirido e dessa forma o aluno torna-se o criador do seu próprio conteúdo. Mas para que isso seja de fato possível, convém uma reestruturação nas instituições de ensino. É necessário que professores e todos os envolvidos no ensino e aprendizagem estejam devidamente capacitados e aptos ao processo. Somando-se a isto, as escolas necessitam de adequado espaço físico e estrutural para desempenhar suas atividades.

Kenski (2008) afirma que as tecnologias são o uso do raciocínio do homem quando são postas em prática, dando origem a diferentes equipamentos, instrumentos, recursos, produtos, processos e ferramenta. Para o senso comum é o estudo sobre técnicas, processos, métodos, meios e instrumentos de um ou mais ofícios ou domínios da atividade humana.

Neste contexto, o presente trabalho de pesquisa traz como tema "Os desafios do uso de laboratórios de informática nas escolas públicas", buscando investigar como esses desafios se materializam na escola pesquisa, a partir dos usos que os docentes fazem dos recursos de TICs, tanto em sala de aula, quanto no laboratório de informática da escola. 
A escola em questão possui um pequeno laboratório de informática que contém 15 computadores, mas apenas 7 funcionam corretamente, o qual é usado esporadicamente por alunos e professores. Partindo desse pressuposto que a prática é fundamental para consolidar o conhecimento teórico da disciplina, surge a necessidade de entender como funciona a didática escolar e consequentemente adaptá-la para agregar maior eficácia no rendimento escolar.

Sendo assim, o presente trabalho de pesquisa justifica-se pela necessidade de identificar quais os usos que os professores da escola pesquisada fazem dos recursos de tecnologias de informação.

Como objetivo da pesquisa, buscou-se entender, por meio da explanação dos docentes da Escola Estadual José Martins de Vasconcelos, suas ideias e atitudes com relação ao uso da informática nas suas práticas educativas na escola. Para tanto, investigou-se como os docentes da escola interpretam a inclusão da informática nas suas aulas, bem como buscou-se identificar as dificuldades dos docentes relacionadas ao uso da informática nas suas aulas.

\section{REVISÃO DE LITERATURA}

As TICs são ferramentas de trabalho dos professores, empresários, publicitários, jornalistas, comunicadores e tantos outros, que aproveitam destes meios em diversos campos de atividade. Constituem-se em tecnologias usadas para informação e servi de meio na comunicação, envolvendo hardware de computadores, redes, celulares, softwares de busca e navegação, documentos colaborativos como o Google docs., ferramentas de conferência audiovisuais com Whatsapp Angus entre outros. Correspondem a todas as tecnologias que interferem e mediam os processos informacionais e comunicativos.

Com a evolução dos hardwares e softwares foi assegurado à instrumentalização da comunicação e dos processos decorrentes em meios virtuais, mas foi a popularização da internet que colocou de vez o uso das TICs em diversos campos inclusive a educação.

Por meio da colaboração, profissionais que se encontram distantes geograficamente trabalham em equipe. As trocas de informa- 
ções geram novos conhecimentos e competências entre os profissionais abrindo novo horizonte, novas perspectivas, novas soluções.

Moran (2007) Diz que as tecnologias digitais hoje são muito acessíveis, instantâneas e podem ser utilizadas para se aprender em qualquer lugar, tempo e de múltiplas formas.

As tecnologias na educação são mais do que recursos didáticos, ampliam e modificam a forma de mediação na relação professor e aluno, ensinar e aprender causa uma ruptura com o pensamento hierárquico dessa relação e, portanto, permite ao aluno construir seu próprio conhecimento com um material vasto disponível, como Whatsapp Hotmail, twitter, instagran para interagir com práticas educacionais.

A escola deve fornecer experiências pedagógicas aos estudantes para construir e produzir esta tecnologia mental colaborativa. Kenski (2008) enfatiza que: a escola deve assumir o papel de capacitar os cidadãos para a complicação do mundo e os desafios que ele propõe, preparar cidadãos conscientes para lidar criticamente com informações e mudanças excessivas, para lidar com inovações e sucessivas transformações de conhecimento em todas as áreas.

\subsection{A formação de professores}

É fundamental que o professor esteja em constante processo de formação, buscando sempre a nova maneira de aprimorar as suas práticas pedagógicas, pois com esta busca constante pela capacitação continuada ele será capaz de melhorar sua prática pedagógica considerando a sua trajetória pessoal, pois a carreira profissional do educador também se relacionada à sua vida pessoal, assim ele seguirá em procura das suas realizações enquanto professor. Para Moran a mudança na educação depende basicamente da boa formação dos professores:

Bons professores são as peças-chave na mudança educacional. Os professores têm muito mais liberdade e opções do que parece. A educação não evolui com professores mal preparados. Muitos começam a lecionar sem uma formação adequada, principalmente do ponto de vista pedagógico. Conhecem o conteúdo, mas não sabem como gerenciar uma classe, como motivar diferentes alunos, que dinâmicas utilizar para facilitar a aprendiza- 
gem, como avaliar o processo ensino-aprendizagem, além das tradicionais provas (MORAN 2007, p.18).

A formação está ligada ao desenvolvimento do ensino, e da profissão docente. A formação de professores traz aspectos importantes que constituem o ser professor. Para Alves (1991), a formação permanente dos professores tem como objetivos: possibilitar a participação do professor na organização dos processos de formação; satisfazer as necessidades do professor enquanto indivíduo; ampliar o campo das experiências profissionais do professor; e prepará-lo para a mudança e eficácia.

\subsection{O professor e as TICs}

Correia (2003) também diz que o que deve ser considerado nessa relação entre professor/aluno e computador, é a análise crítica do professor ou do aluno no que diz respeito ao conhecimento quantitativo e qualitativo da tecnologia, implicando assim na forma que se deve utilizá-la.

Ainda sobre o contexto da utilização da TICs na escola, Rosa (2013, p. 1) afirma que, "diante deste cenário pode-se dizer que um desafio imposto aos professores ao utilizarem as tecnologias é de compreendê-las de forma cada vez mais abrangente tornando-as parte de seu trabalho docente". Ou seja, os professores hoje em dia ainda têm muitas dificuldades em dominar as tecnologias para levar para dentro da sala de aula.

O que ocorre é que na sua formação muito pouco ou quase nada é visto no que diz respeito a informática. Oderico (2012), em sua análise de um questionário, "revelou que, em sua maioria, a formação inicial do professor não contemplou tópicos relacionados ao uso da informática no ensino. Apenas $14 \%$ dos docentes da primeira escola e $11 \%$ dos docentes da segunda escola afirmaram que tenham participado de algum curso relacionados a recursos computacionais em sua formação."

O professor tem que estar preparado para a vivência nas escolas e nas aulas no seu dia a dia, pois para que seja inserido a compu- 
tação nas aulas os docentes devem se sentir seguros com o que está fazendo. Sobre isso, Almeida e Valente (2011) afirmam que:

[...] uma das principais barreiras à integração curricular das TIC não se limita, portanto, à dificuldade de apropriação técnica das tecnologias, mas sobretudo à dificuldade em compreender as inúmeras possibilidades de diversificação de estratégias e de soluções sobre o que fazer com as mesmas (...) existe uma interligação ou dialética entre a competência técnica e a competência pedagógica que crescem em interdependência e em espiral. [...] (ALMEIDA; VALENTE, 2011, p. 29).

A formação dos professores não inclui nada referente a informática como é destacado por Libâneo (1998) que diz que as resistências ao uso da informática existem, pois não são trabalhadas nos processos de formação inicial e contínua do docente. Ele ainda afirma que isso poderia ocorrer a partir da integração das novas tecnologias aos currículos, do desenvolvimento de habilidades e da formação de atitudes favoráveis ao emprego dessas tecnologias.

Em contrapartida, não existem apenas o caso de os professores não serem preparados como deveria. Existe também a parte de infraestrutura das escolas que em muitas vezes não são adequadas para o uso. Em seu estudo de caso, Bittar (2000), em conversas com os profissionais relataram que uma das dificuldades enfrentadas por eles era que não existem máquinas para todos os alunos o que implica na forma de ser feita a avaliação dos trabalhos.

Assim como foi descrito por Ribeiro (2017), os laboratórios muitas vezes parecem sucateados devido à falta de manutenção dos computadores, e quando são feitas manutenções nunca volta da forma que deveria, o que acaba impossibilitando o seu uso. Entretanto, não podemos acreditar que apenas a inclusão do computador na sala de aula seja suficiente para melhor a aprendizagem dos alunos, mas pode servir de pontapé inicial para o processo de modernização do ensino e aprendizagem.

Enfim, uma mudança na forma como é sistematizado o ensino atualmente das escolas brasileiras implica em mudanças consideráveis e é isso que torna o desafio ainda maior na mudança da realidade nas salas de aulas. 


\section{METODOLOGIA}

A metodologia adotada, com inspiração empírica e teórica na abordagem qualitativa, destacou a escola estadual de ensino fundamental do município de Mossoró/RN, para aplicação de entrevista semiestruturada, com levantamento da formação dos professores, experiências vividas e planejamento das atividades a serem desenvolvidas no laboratório de informática.

A escola que foi escolhida para realização de uma pesquisa de campo é uma escola da rede pública estadual da cidade de Mossoró, com o intuito de investigar como estava sendo utilizado o laboratório de informática na escola. Sendo assim, foi pesquisado junto aos professores da escola o ambiente da escola, turnos de funcionamento, público-alvo da mesma.

Ela se deu por meio de formulário na web, onde será repassada para que os professores possam acessar de forma fácil e direta e que podem serem respondidas até mesmo pelos seus smartphones.

O questionário foi elaborado para compreendermos a realidade da escola pesquisada e foi respondida por diretores, vice-diretores, professores e pedagogos da escola em questão, com o objetivo de identificar a situação da infraestrutura do laboratório de informática, uso pedagógico do laboratório e as dificuldades vivenciadas pelos professores na escola escolhida.

Foram elaboradas questões com o objetivo de coletar dados classificados em 4 categorias, a saber: a) Identificação dos sujeitos; b) Formação e experiência docente; c) Uso dos recursos informatizados; e, d) Inserção da informática na educação.

$\mathrm{Na}$ categoria "Identificação dos sujeitos" foram perguntadas a idade e o gênero dos sujeitos participantes da pesquisa, com o objetivo de traçar seu perfil.

$\mathrm{Na}$ categoria "Formação e experiência docente" foram perguntadas a área de graduação e ano de conclusão, a área da especialização e o ano de conclusão, as capacitações cursadas (ofertadas pela escola, pela rede de ensino, por iniciativa própria), a área de atuação na docência, o nível de ensino em que atua e o tempo de experiência em docência. 
Na categoria "Uso dos recursos informatizados" foi perguntado se o professor possui computador em casa, qual a tecnologia que utiliza para o acesso à internet, quanto tempo faz uso da internet por dia, se o professor faz uso do laboratório de informática da escola e com qual frequência, se o professor se sente seguro para fazer uso de tecnologia em suas aulas, caso não, por quais motivos, quais recursos tecnológicos são disponibilizados pela escola e, destes, quais o professor usa em suas aulas.

$\mathrm{Na}$ categoria "Inserção da informática na educação" foi perguntada a opinião do professor sobre algumas questões, como: a) quais motivos justificariam a inserção de recursos tecnológicos na educação; b) o que seria o uso da tecnologia na escola; c) se existem problemas que dificultam o uso do laboratório de informática e quais são; e, d) Se o professor teve alguma experiência significativa com o uso dos computadores realizada por professores e alunos na escola e qual(is) foi(ram).

Anteriormente à aplicação dos instrumentos de coleta foi obtida a autorização da direção da escola para, bem como diretor e professores foram orientados sobre o teor do questionário e qual era o objetivo da sua aplicação.

A abordagem de aplicação dos instrumentos foi realizada presencialmente com aplicação direta dos questionários com os professores.

\section{O CAMPO DE PESQUISA}

A escola escolhida para realização da pesquisa foi a Escola Estadual Vasconcelos (figura 1), localizada no bairro Liberdade, zona urbana da cidade de Mossoró. A escola, fundada em 1983, conta com mais de 500 alunos, distribuídos nos turnos matutino e vespertino, segundo os registros da própria supervisão da escola. À época da coleta de dados com a direção da escola, o corpo docente era composto de 26 professores efetivos, 2 supervisoras, atuando coordenadora e supervisora pedagógicas e 25 funcionários. 


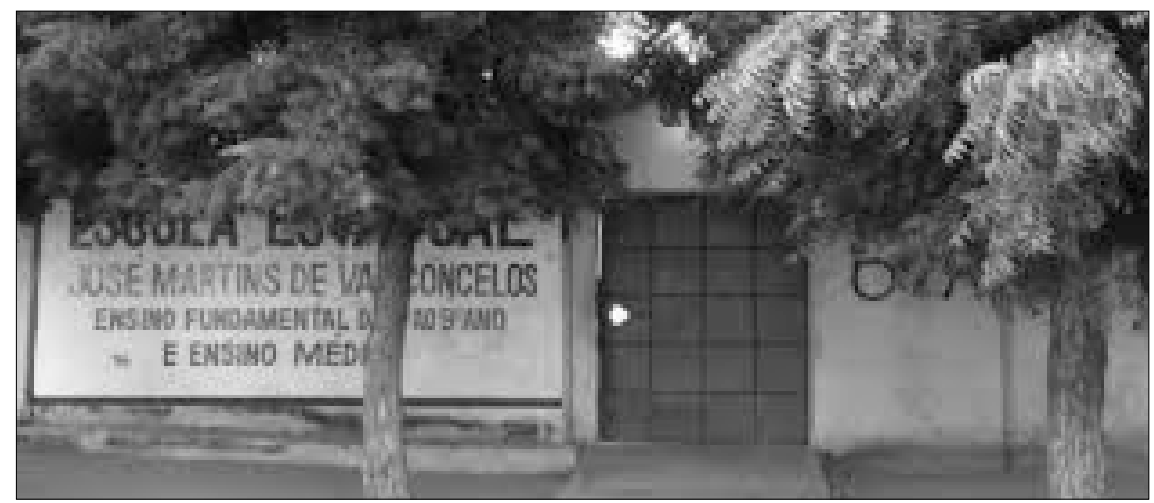

Figura 1 - Fachada da Escola Estadual José Martins de Vasconcelos Fonte: Google Maps

O contato inicial com a escola se deu a partir da realização do Estágio Supervisionado IV, no segundo semestre de 2017, com o cumprimento de carga horária referente a um turno semanal na escola. Durante a realização do estágio foi possível conhecer toda a estrutura física da escola, através de visita às principais áreas, como diretoria, secretaria, biblioteca, área de convivência e o laboratório de informática.

O contato com o laboratório de informática, com as principais dificuldades dos professores e com as condições de trabalho para todos os funcionários e professores motivaram a realização da presente pesquisa de conclusão de curso.

A escola conta com sete salas de aula, cozinha, biblioteca, um laboratório de informática, sala de professores e secretaria. O laboratório de informática é composto por 15 computadores, todos com o Linux Educacional (sistema operacional com instalação de fábrica nos computadores licitados pelo FNDE e disponibilizados para as escolas públicas no Brasil). Desses computadores apenas sete estavam funcionando corretamente. Os demais estavam no aguardo do governo enviar o técnico para o diagnóstico e conserto dos mesmos.

Quanto ao nível de informatização da escola, ou de adoção de tecnologias para a realização de tarefas de gestão administrativa ou gestão pedagógica, foi possível observar que a organização dos históricos, as matrículas, o controle, armazenamento e recuperação dos dados dos alunos; tudo realizado de forma manual, sem a adoção de um sistema de gestão. 
Durante as observações das aulas dos professores foi possível identificar que poucos fazem uso das TICs para a realização das suas aulas; dos poucos que utilizam, preparam aulas tradicionais, expositivas, somente apresentando os conteúdos em formato de slides, com o auxílio de um projeto digital (datashow).

Também foi possível verificar que a área de computação ainda tem muito a crescer e melhorar, pois não existem profissionais qualificados na escola para ministrar aulas de informática, os computadores estão defasados e também não existem uma pessoa responsável por fazer a organização do laboratório.

\section{ANÁLISE E DISCUSSÃO DOS RESULTADOS}

Os participantes da pesquisa foram professores em regência de classe, que atuam na Escola Estadual José Martins de Vasconcelos. Todos os professores da escola foram solicitados a participar da pesquisa, mas somente 11 (onze) aceitaram contribuir com suas respostas.

No que se refere a identificação do perfil dos respondentes, foram analisadas duas variáveis: faixa etária e gênero.

Quanto à faixa etária, como pode ser observado no gráfico 1 , $54,6 \%$ dos respondentes tem mais de 35 anos.

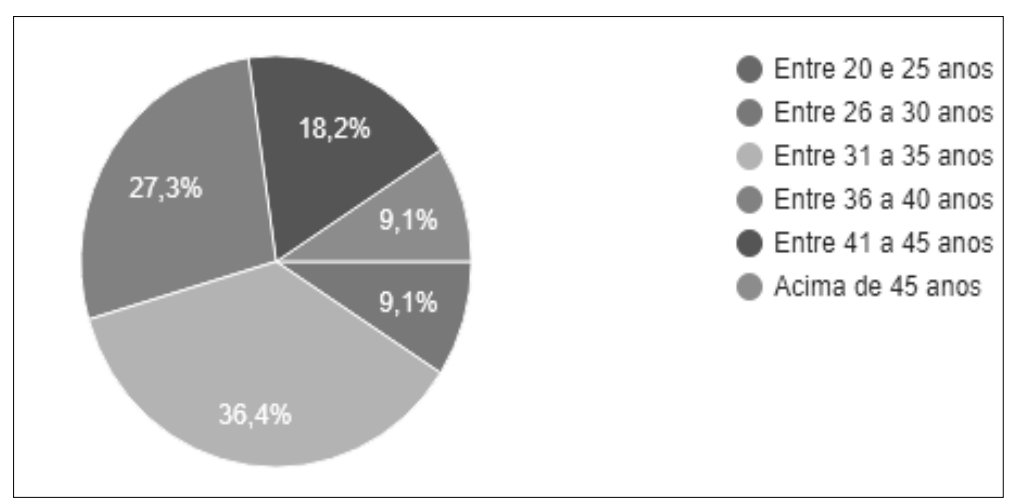

Gráfico 1 - Distribuição dos professores quanto à faixa etária

Fonte: Elaborado pelo autor (2019) 
Quanto ao gênero, os professores da escola são, majoritariamente, homens $(63,3 \%)$.

No que se refere a formação e a experiência docente foram perguntadas a área de graduação e ano de conclusão, a área da especialização e o ano de conclusão, as capacitações cursadas (ofertadas pela escola, pela rede de ensino, por iniciativa própria), a área de atuação na docência, o nível de ensino em que atua e o tempo de experiência em docência.

Quanto à área de graduação pode-se verificar que os professores estão distribuídos por diversas áreas do conhecimento, com uma certa prevalência para as graduações em Letras, independentemente de sua habilitação (gráfico 2). Porém, quanto ao tempo de conclusão da graduação, aproximadamente $63,6 \%$ dos professores concluíram seus cursos de graduação há 10 anos ou mais e 36,4\% há menos de 10 anos, sendo que destes nenhum concluiu há menos de 3 anos.

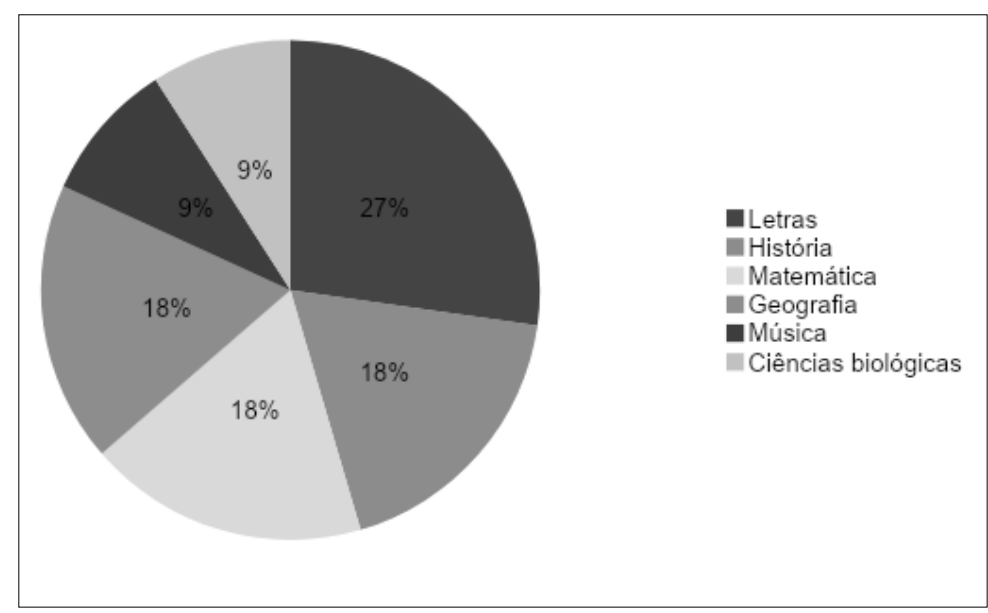

Gráfico 2 - Distribuição dos professores quanto à área de graduação Fonte: Elaborado pelo autor (2019)

Quanto aos cursos de especialização 81,82\% dos professores cursaram alguma especialização e somente 18,18\% não possuem algum curso de especialização. Já no que se refere às áreas dos cursos, em sua maioria, os professores cursaram especialização com relativa aderência às suas áreas de graduação, cuja distribuição por áreas pode ser observada no gráfico 3 . 
No entanto, no que se refere ao tempo de conclusão dos cursos de especialização, aproximadamente $77,8 \%$ dos professores concluíram seus cursos há 5 anos ou mais e 22,2\% há menos de 5 anos.

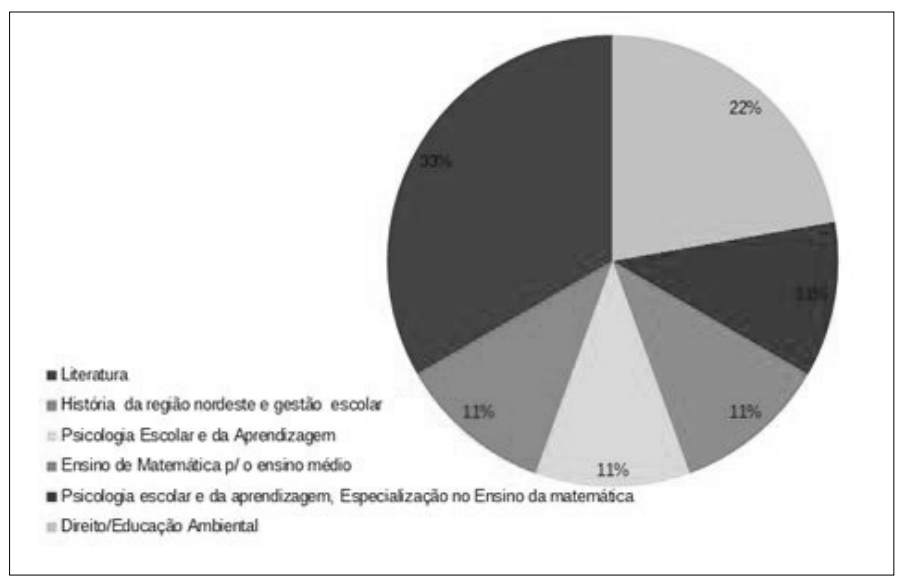

Gráfico 3 - Distribuição dos professores quanto à área de especialização Fonte: Elaborado pelo autor (2019)7

Quando perguntados sobre as capacitações cursadas, sejam elas ofertadas pela escola ou pela rede de ensino, os professores citaram os cursos listados no quadro 1.

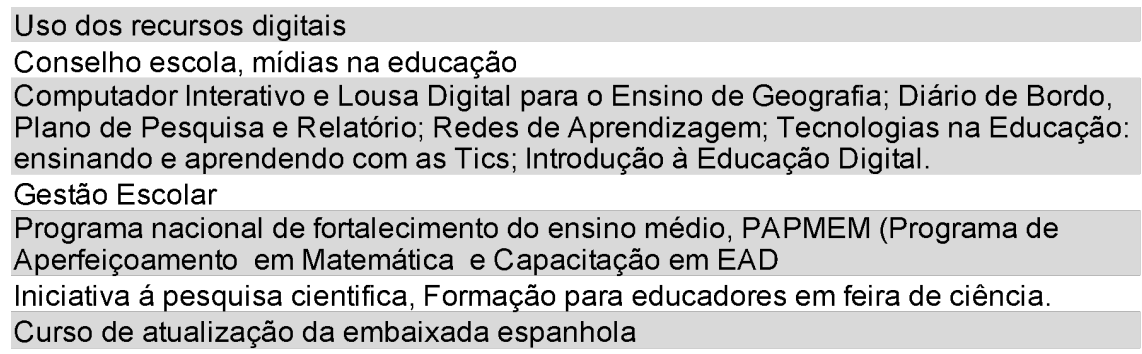

Quadro 1 - Cursos de capacitação ofertados pela escola ou pela rede Fonte: Elaborado pelo autor (2019)

Observando-se os cursos citados pelos professores, pode-se observar (gráfico 4) que estes estão organizados em 3 diferentes grupos: os que não cursaram capacitações, os que cursarem capacitações em TICs e em outras áreas, e os que somente cursaram capacitações em outras áreas. 


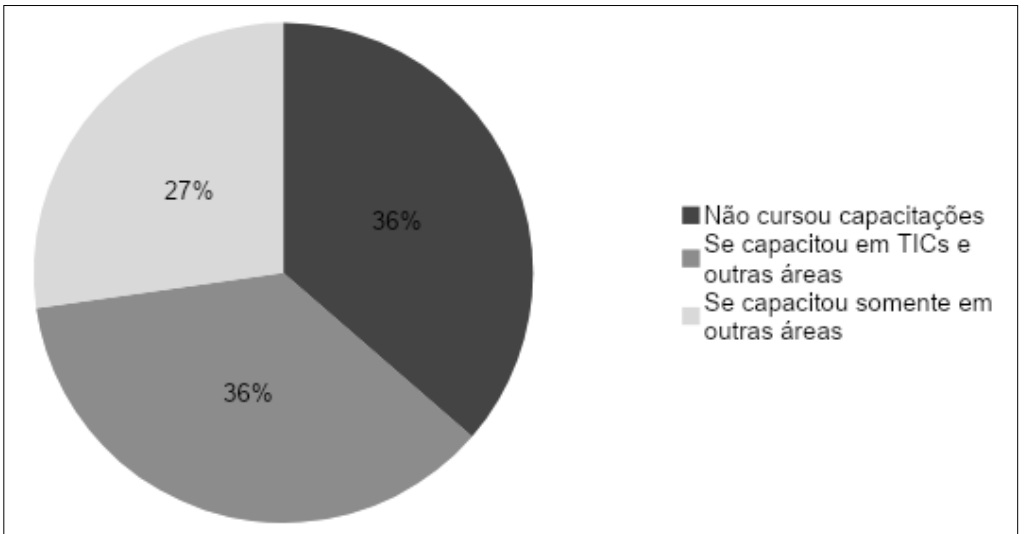

Gráfico 4 - Distribuição dos professores quanto ao tipo de capacitação (ofertada pela escola ou pela rede)

Fonte: Elaborado pelo autor (2019)

Quando comparados os resultados das capacitações ofertadas pela escola ou pela rede, cursadas pelos professores, com as capacitações cursadas por eles por iniciativa própria, percebe-se que o percentual de professores que não cursou capacitações caiu de $36 \%$ para $18 \%$, o que pode significar que, apesar das ofertas de cursos pela rede ou pela escola, os professores estão buscando por capacitações. Porém, no que se refere aos professores que se capacitaram em TICs, os 36\% capacitados em TICs por cursos ofertados pela escola ou pela rede, passaram a ser somente $27 \%$ capacitados em TICs por iniciativa própria.

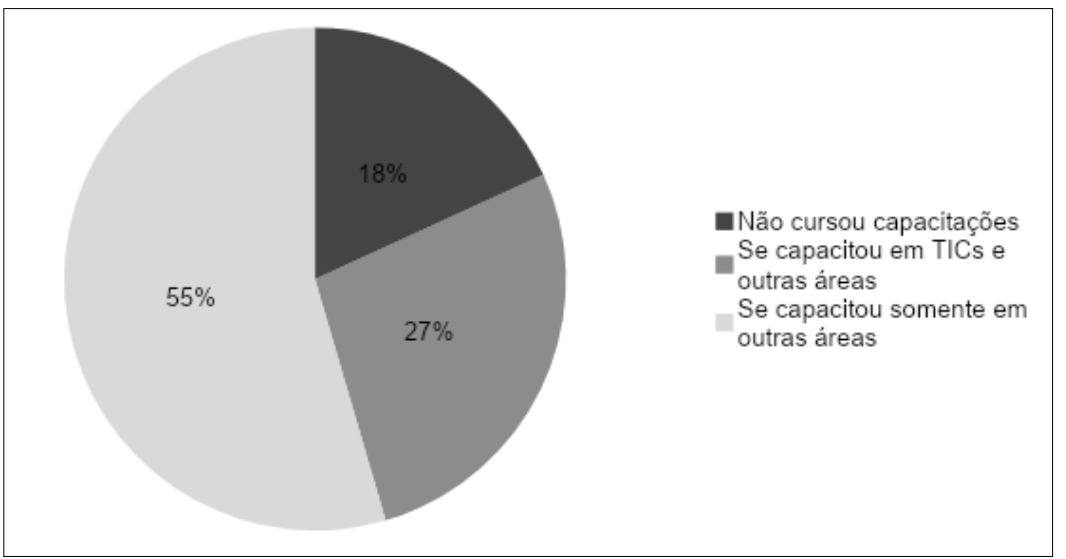

Gráfico 5 - Distribuição dos professores quanto ao tipo de capacitação (cursadas por iniciativa própria

Fonte: Elaborado pelo autor (2019) 
Quanto a área de atuação na docência, quando comparadas as áreas de atuação dos professores às áreas de graduação e/ou especialização destes percebe-se que somente $9 \%$ atuam fora de sua área de formação, na escola pesquisada.

Quando observados os dados sobre o nível de ensino em que os professores atuam, 18,2\% dos professores atuam somente no ensino Fundamental II, 36,4\% atuam somente no ensino Médio e 36,4\% atuam em ambos os níveis de ensino. Cabe ressaltar que não foram registradas atuações no ensino Fundamental I em função da pesquisa ter sido realizada em uma escola da Rede Estadual de Ensino Básico, que contem somente os níveis de ensino Fundamental II e Médio.

No que se refere ao tempo de experiência em docência, 72,7\% possuem mais de 10 anos de experiência, com destaque para o fato de que somente 1 dos professores possui menos de 1 ano de experiência (gráfico 6).

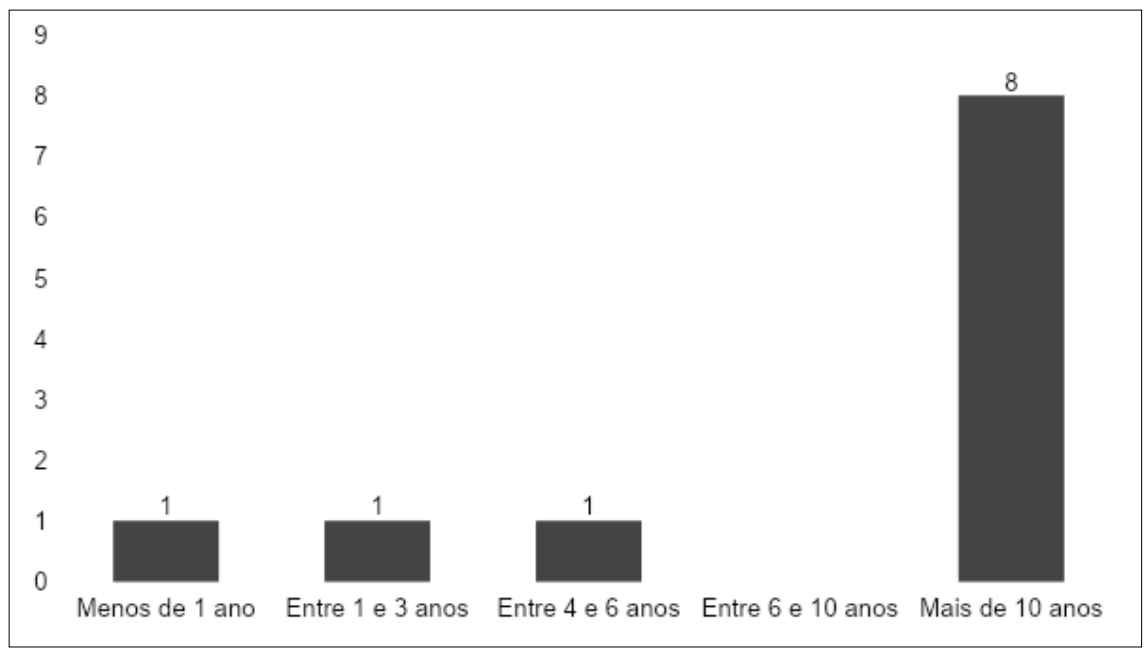

Gráfico 6 - Distribuição dos professores quanto ao tempo de docência Fonte: Elaborado pelo autor (2019)

No que se refere ao uso dos recursos informatizados foi perguntado se o professor possui computador em casa, qual a tecnologia que utiliza para o acesso à internet, quanto tempo faz uso da internet por dia, se o professor faz uso do laboratório de informática da escola e com qual frequência, se o professor se sente seguro para fazer uso de tecnologia em suas aulas, caso não, por quais motivos, quais 
recursos tecnológicos são disponibilizados pela escola e, destes, quais o professor usa em suas aulas.

Quando perguntado se possui computador em casa $100 \%$ dos professores disseram possuir algum. Já quanto ao tipo de recurso tecnológico utilizado para acessar internet os citados foram computador de mesa, notebook, tablet, smartphone/celular, com prevalência para notebooks e smartphones; sendo que, em maioria, os professores disseram utilizar mais um tipo de recurso para acesso à internet. Quanto ao tempo diário de uso da internet, mais de $90 \%$ dos professores disseram usar a internet entre 1 e 4 horas por dia, sendo que somente $9 \%$ disseram usar até 1 hora e nenhum relatou usar 5 horas ou mais por dia (gráfico 7).

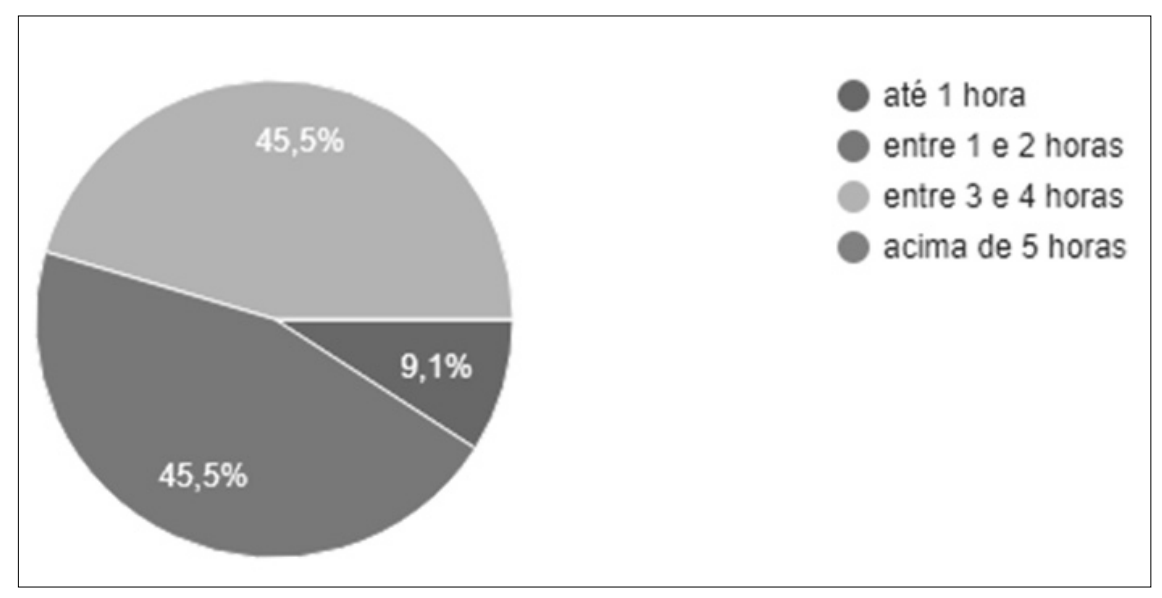

Gráfico 7 - Tempo diário de uso da internet Fonte: Elaborado pelo autor (2019)

Comparando-se o tipo de recurso digital utilizado pelos professores com as horas por dia que passam na internet, pode-se dizer que os professores da escola são relativamente conectados; o que sugere que não teriam dificuldades técnicas em usar recursos digitais em sala de aula, visto que já os utilizam fora dela.

Apesar de a escola possuir laboratório de informática, mesmo que em condições precárias, $100 \%$ dos professores dizem não utilizá-lo, sob a alegação de não possuir laboratório de informática na escola. Em contrapartida, aproximadamente $82 \%$ dos professores dizem 
sentir-se seguros e somente $18 \%$ dizem não sentir-se seguros em usar o laboratório de informática da escola; todos sob a alegação de não possuir a infraestrutura adequada.

Quando perguntados sobre quais os recursos tecnológicos a escola disponibiliza, os professores citaram caixa de som, datashow e computadores para os professores, porém quando questionados sobre o uso desses recursos somente 54\% disseram usar caixa de som em suas aulas, sendo que a maioria diz utilizar o datashow. Esses resultados são corroborados na pesquisa de Pimenta (2018), também realizada em uma escola da rede pública de ensino básico de Mossoró, na qual afirma que, apesar de possuírem formação para o uso de TICs, somente utilizam o datashow em um formato de aula expositiva tradicional.

Segundo Santos e Braga (2004), os professores encontram mais dificuldades para incorporar o computador e rede ao seu fazer pedagógico.

Seguindo essa linha de raciocínio, ir às escolas e colocar laboratórios de informática com computadores novos, com acesso à internet e outros recursos tecnológicos, não quer dizer que está sendo inserido uma nova proposta pedagógica no processo de ensino. Deve-se ser investido na formação continuada dos professores, pois o conhecimento de aplicações pedagógicas dos recursos é mais importante que sua simples presença.

No que se refere à inserção da informática na educação foi perguntada a opinião do professor sobre algumas questões, como: a) quais motivos justificariam a inserção de recursos tecnológicos na educação; b) o que seria o uso da tecnologia na escola; c) se existem problemas que dificultam o uso do laboratório de informática e quais são; e, d) Se o professor teve alguma experiência significativa com o uso dos computadores realizada por professores e alunos na escola e qual(is) foi(ram).

Quanto aos motivos justificariam a inserção de recursos tecnológicos na educação, a maioria dos professores afirma que encaram a informática como fomentadora de uma nova possibilidade de aprendizado, pensamento e crescimento emocional e cognitivo (quadro2), o que parece estar em consonância com a formação para o uso de TICs, bem como com o uso pelos professores fora da sala de aula, porém em dissonância com uso que estes fazem das TICs na escola. 
Hipótese catalítica - As escolas podem ser mudadas ou modificadas; podem incorporar novos meios de aprendizagem que facilitem a vida do professor e do aluno

Hipótese de ordem pedagógica - Estes encaram a informática como fomentadora de uma nova possibilidade de aprendizado, pensamento e crescimento emocional e cognitivo

Hipótese de ordem social - A informática vai dominar o mundo, então todos devem saber utiliza-la. A escola precisa conhecer como funciona e integrar a suas pratica o quanto antes

Quadro 2 - Justificativas da inserção de TICs na escola Fonte: Elaborado pelo autor (2019)

Quanto às concepções sobre o uso da tecnologia na escola, das 5 citadas no instrumento de coleta somente 3 foram citadas como mais relevantes, a saber: a) computador como meio de aprendizagem por descobertas; b) computador como meio para simulações e jogos; e, c) computador como recurso facilitador de tarefas; como pode ser observado no quadro 3.

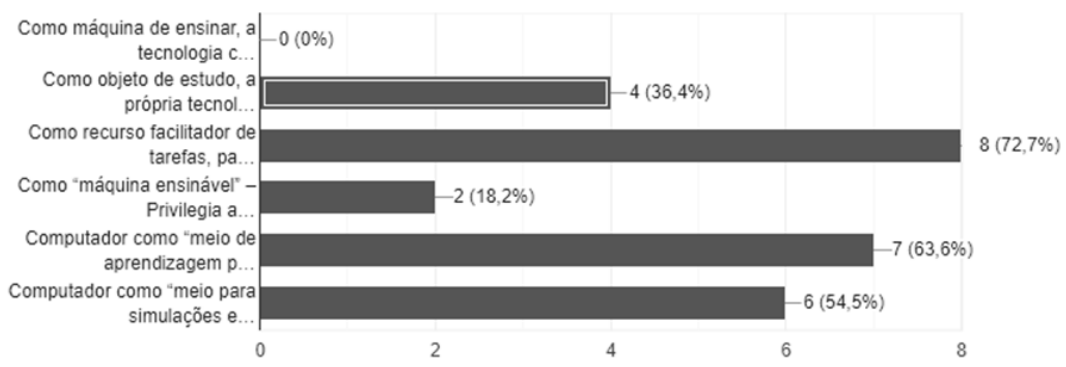

Gráfico 8 - Concepções do uso das TICs na escola

Fonte: Elaborado pelo autor (2019)

Quanto aos problemas que dificultam o uso do laboratório de informática os mais citados foram a ausência de computadores/laboratório de informática na escola e a ausência de internet na escola (quadro 3). 


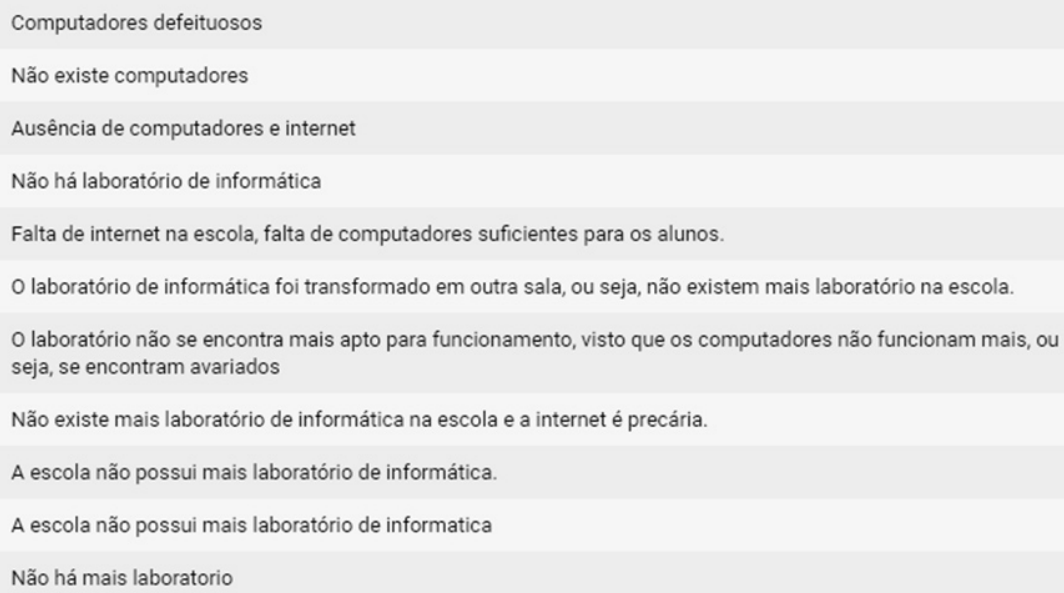

Quadro 3 - Dificuldades para o uso de TICs na escola Fonte: Elaborado pelo autor (2019)

Quando questionados sobre se tiveram alguma experiência significativa com o uso dos computadores realizada por professores e alunos na escola e qual(is) foi(ram), somente dois professores disseram ter que sim; destes, um citou "a correção dos próprios textos", o que não se caracteriza uma experiência com os alunos e, o outro, citou o "uso de mapas e imagens nas aulas de história", equivalendo à somente $13,7 \%$ dos professores com alguma experiência significativa no uso de TICs com os alunos na escola.

Assim, analisando-se os dados coletados na escola é possível perceber que, para que as TICs sejam inseridas de fato as escolas é necessário que seja feita uma melhor estruturação das escolas e dos professores, pois os mesmos por mais que se digam seguros para ministrar uma aula no laboratório de informática, não o fazem por vários fatores e um deles é a questão da sua formação. Segundo Almeida e Valente (2011) seria necessária:

[...] uma formação que promovesse de forma equilibrada o desenvolvimento de competências técnicas, pedagógicas e sociais, em articulação estreita com a aquisição e o desenvolvimento das dimensões investigativa e de inovação que a exploração do potencial pedagógico das tecnologias digitais exige (ALMEIDA; VALENTE, 2011, p.42). 
Aspectos estes que também são reafirmados por Silva e Costa (2016) que, juntamente os demais capítulos da série Professor Criativo, em seu volume "Educação criativa: multiplicando experiências para a aprendizagem" ressaltam, não somente as contribuições do uso das TICs na escola, como também da capacitação/qualificação dos professores para uso de tais recursos tecnológicos.

\section{CONSIDERAÇÕES FINAIS}

$\mathrm{O}$ avanço das ciências e tecnologias produz transformações que criam desafios que geram conflitos e conformismo da escola. Com isso, entender as razões pelas quais as escolas são influenciadas a adotar recursos informatizados traz a possibilidade de definir a teoria e a prática sobre a compreensão das representações dos professores, que são peças fundamentais na condução de trabalho em busca de melhorias da escola.

A inclusão de inovações na escola é uma ação que movimenta, basicamente, todos os setores da escola. Vemos que os professores ficam inseguros e inquietos com a possibilidade de mudanças que alterem a sua posição dentro da escola, que traga mais atividades para o seu dia a dia.

Com a pesquisa realizada na escola, foi observado que existem muitas dificuldades na situação da infraestrutura e o uso do laboratório, sendo necessário que os gestores e professores prevejam meios de estimular a inclusão digital na escola.

Os docentes da escola estudada acreditam que o uso da tecnologia é uma ferramenta eficaz no aperfeiçoamento do processo educacional. O seu uso cria novas formas de ensino-aprendizagem, trazendo a educação características inovadoras capazes de motivar os professores e os alunos. Com ela é possível fazer uma mudança significativa para o desenvolvimento da criatividade, da autonomia e da possibilidade de construir o próprio conhecimento. As ferramentas tecnológicas são bastante atrativas aos alunos. A utilização dentro do contexto aliada à realidade dos alunos, provoca impacto e motiva o interesse. 
Um ponto que nos serviu de reflexão, a partir dos dados de pesquisa, foi o completo abandono dos laboratórios de informática, onde na escola pesquisada foi descontinuado por falta de manutenção e investimentos. Um programa governamental precisa conceber a descentralização de funções, além de uma divisão de responsabilidades.

Com isso, entende-se que para que seja adotado e usado as práticas pedagógicas que façam uso de ferramentas tecnológicas nas escolas, é necessário que seja revisto a formação dos professores, onde pode ser modificado para uma formação continuada dos docentes.

Esse tema de pesquisa não se encerra aqui, pois além identificar e investigar as interpretações dos docentes, é importante, partindo dessa comprovação, conseguir pensar e aplicar, com os professores, um modelo para a formação continuada na educação. Essa mudança deve promover uma mudança do paradigma de resistência para a sua aceitação.

\section{REFERÊNCIAS}

ALMEIDA, M.; VALENTE, J. A. Tecnologias e currículo: trajectórias convergentes ou divergentes? SãoPaulo: Paulus, 2011.

ARAUJO, N. M. S.; RIBEIRO, F. R.; SANTOS, S. F. dos. Jogos pedagógicos e responsividade: ludicidade, compreensão leitora e aprendizagem. Bakhtiniana, Rev. Estud. Discurso [online]. 2012, vol.7, n.1, pp. 4-23.

CAMBOIM, A. F. L; BARROS, A. C. P. RELACIONAMENTO MERCA DOLÓGICOCOM OS CIBERNATIVOS NA INTERNET. In: Anais do XII Congresso de Ciências da Comunicação na região Nordeste. São Paulo: INTERCOM, 2010, v.1.

CORREIA, D. S. Utilização dos laboratórios de informática nas Escolas da Rede Municipal de Itabuna - BA. Florianópolis: UFSC, 2003. GIL, A. C. Métodos e técnicas de pesquisa social. São Paulo: Atlas, 1999.

KENSKI, V. M. Educação e Tecnologias: o novo ritmo da informação. Campinas: Papirus, 2008.

LIBÂNEO, J. C. Adeus professor, adeus professora?: novas exigências educacionais e profissão docente. 2 ed. São Paulo: Cortez Editora, 1998. 
MORAN, J. M. A educação que desejamos: novos desafios e como chegar lá. Papirus Editora, 2007.

MORESI, E. Metodologia da Pesquisa. Brasília: UCB, 2003.

NETO, E. S.; FRANCO, E. S. Os professores e os desafios pedagógicos diante das novas ger ações: considerações sobre o presente e o futuro. Revista de Educação do COGEIME - Ano 19 - n.36 - janeiro/ junho 2010.

ODORICO, E. K.; NENES, D. M.; MOREIRA. A.; OLIVEIRA, H. M. P.; CARDOSO, A. Análise do não uso do laboratório de informática nas escolas públicas e estudo de caso. Rio de Janeiro: UFRJ, 2012. PIMENTA, E. F. O impacto das TICs e a relevância que os professores capacitados para usá-las podem proporcionar a educação (Monografia de graduação). Mossoró, UFERSA, 2018.

RIBEIRO, J. C.; SILVA, A. M. C. Uma análise sobre o uso do computador nos laboratórios de informática do PROINFO nas escolas públicas municipais da cidade de Codó - MA e suas contribuições para a aprendizagem. São Luis: UFMA, 2017.

ROSA, R. Trabalho docente: dificuldades apontadas pelos professores no uso das tecnologias. Revista Encontro de Pesquisa em Educação. v.1. n.1, p. 214-227. Uberaba: Universidade de Uberaba, 2013. SANTOS, G. L.; BRAGA, C B. O uso do computador na educação infantil: um estudo de caso no Distrito Federal. Revista Latino Americana de Tecnología Educativa. Extremadura (Espanha), v. 3, n. 3, p. 10-28, 2004.

SERAFIM, L. B. Tecnologias educacionais e desempenho escolar em cursos de licenciatura a distância (Dissertação de Mestrado). Lavras: UFLA, 2013.

SERAFIM, M. L.; SOUSA, R. P.. Multimídia na educação: o vídeo digital integrado ao contexto escolar. In: SOUSA, R. P.; MOITA, F. M. C. S. C.; CARVALHO, A. B. G.. (orgs.) Tecnologias digitais na educação. Campina Grande: UEPB, 2011. pp. 19-50.

SILVA, K. C.; COSTA, M. N. D.. O uso de jogos digitais como objetos de aprendizagem no ensino da matemática: uma proposta para as escolas públicas do semiárido potiguar. In: RAABE, A. L. A.; GOMES, A. S.; BITTENCOURT, I. I.; PONTUAL, T.. Educação criativa: multiplicando experiências para a aprendizagem (Série professor criativo, IV). Recife: Pipa Comunicação, 2016. pp. 374-409. 


\section{O PROINFO COMO ABORDAGEM HÍBRIDA DE FORMAÇÃO CONTINUADA: O IMPACTO DAS TICS \\ E A RELEVÂNCIA QUE PROFESSORES CAPACITADOS PARA USÁ-LAS PODEM PROPORCIONAR À EDUCAÇÃO}

Enoy Fernandes Pimenta Kátia Cilene da Silva

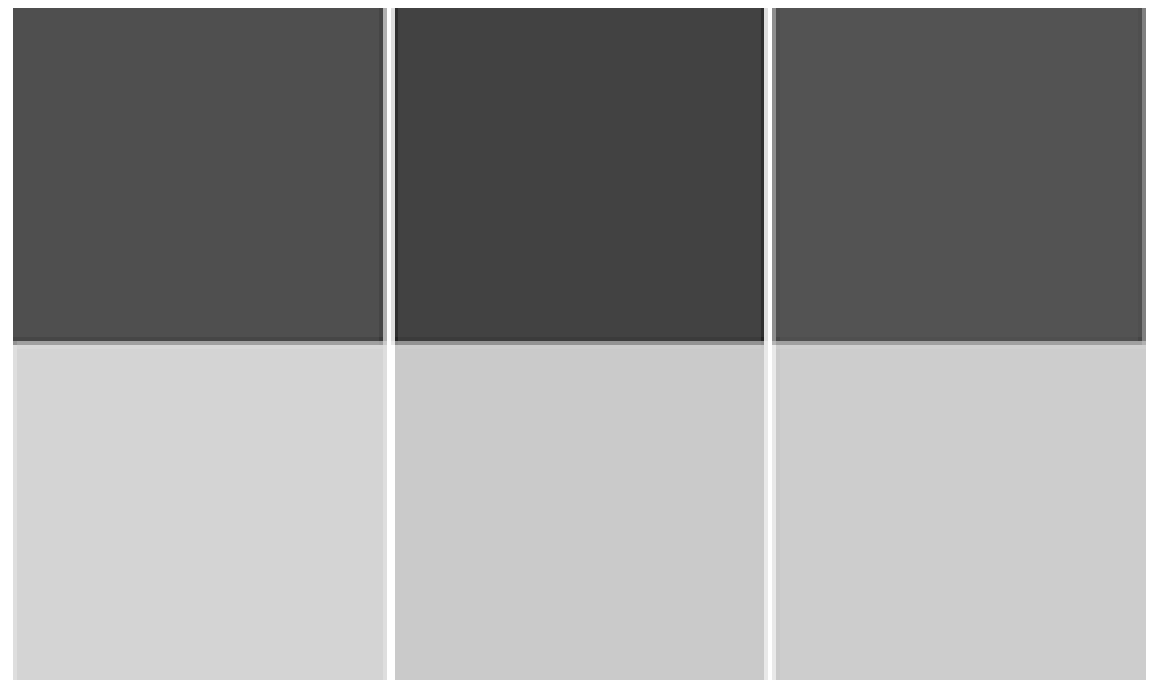




\section{INTRODUÇÃO}

A introdução das tecnologias da informação e comunicação (TICs) em contexto escolar tem sido alvo de reflexão e análise, em relação aos impactos que elas têm e às mudanças que podem provocar no processo de ensino-aprendizagem. Elas podem ser um recurso auxiliar para dinamizar e potenciar as aulas do professor, criando ou atualizando as políticas ligadas ao seu uso. Verificando a limitações do ambiente e se esse ambiente possibilita à utilização de tecnologias conectadas a internet, conscientizando-se sobre sua importância, expandindo e melhorando as opções de conexão.

A utilização das TICs na educação depende, quase sempre, da melhoria da infraestrutura do seu ambiente. Elas devem ser trabalhadas no desenvolvimento das suas metodologias, oferecendo acesso a todos dentro da sala de aula, garantindo igualdade de utilização sem distinção de sexo. Por isso considera-se que a educação e suas atividades não deve oferecer nenhuma discriminação quanto ao perfil do seu usuário. Qualquer atividade deve ser levada em conta, criando e tirando maior proveito do conteúdo educacional onde Todo o material criado deve ser pensado no formato de uma nova dinâmica de aula, onde se utilizem as tecnologias inclusivas para criar e usar o material didático, treinando os professores, tornando-os aptos e seguros para utilizar as TICs na sala de aula, promovendo o uso saudável e responsável delas. A tecnologia na educação não devem ser uma barreira e sim um meio de estímulo de comunicação entre pais, professores e estudantes.

A maioria das escolas ainda não se beneficia dessas tecnologias, mesmo tendo na sua dependência hardwares e softwares cedidos pelo Governo Federal pelo Programa Nacional de Tecnologia Educacional (Proinfo) que é um programa educacional criado pela Portaria $n^{\circ}$ 522/MEC, de nove de abril de 1997, para promover o uso pedagógico das TICs na rede pública de ensino fundamental e médio. Somente a introdução dos computadores na escola não é suficiente para tornar o ensino e aprendizagem eficiente, é preciso formar também os professores, em cursos preparatórios para saber utilizar com confiança e maestria estas ferramentas. 
A aplicação e mediação que o docente faz em sua prática pedagógica do uso das TICs em sala de aula dependem de como ele entende essas ferramentas, de que maneira eles devem se apropriar, relacionando as TICs a sua didática e a capacidade cognitiva que envolve pensamento, raciocínio, abstração, linguagem, memória, atenção, criatividade, capacidade de resolução de problemas, entre outras funções.

A presente pesquisa tem como objetivo mostrar os impacto das TICs e a relevância que professores bem preparados para usá-las podem proporcionar a educação.

Este trabalho justifica-se na importância da preparação do professor em contribuição para a educação com o melhor uso das TICs. Isso é, mostrará o que teremos de melhor, quando os professores se capacitam para usá-las.

\section{METODOLOGIA}

A pesquisa científica está tomando seu lugar em cursos de educação superior em várias universidades. Este foi considerado um lugar onde a cultura universal é vivida e cujo propósito é o ensino, a pesquisa e a extensão, sendo organizado para a formação de profissionais que trabalharão na sociedade (RODRIGUES, 2006).

Este estudo permitiu verificar que, quando houvesse preparação e planejamento no trabalho de ensino aliado às tecnologias da informação na área pedagógica, os benefícios para os alunos se tornaram evidentes. A metodologia utilizada nesta atividade foi à pesquisa bibliográfica, com coleta de dados no campo; fazendo uso de conhecimentos de pesquisa já utilizados por outros para resolver problemas.

Para chegar aos objetivos desta pesquisa, no primeiro momento foi feita uma pesquisa explicativa, como uso da pesquisa bibliográfica sobre o fato de usar materiais já elaborados: livros, artigos científicos, revistas, documentos eletrônicos e enciclopédias. No segundo momento, feito uma pesquisa de campo classificada como indutiva na pesquisa e alocação de conhecimento sobre quais ferramentas digitais os professores estavam usando para mediar à pesquisa de ensino para seus alunos, relacionando esse conhecimento com abordagens já trabalhadas por diversos autores. 
O presente artigo estrutura-se em quatro seções, a primeira sobre o que são as TICs, explicitações a respeito de sua importância, seus conceitos e características, na segunda a formação continuada de professores, na terceira uma pesquisa de campo e, por último, discorremos sobre a vantagem de se ter professores preparados tecnologicamente.

\section{O QUE SÃO AS TICs?}

Antes de descrevermos a respeito das tecnologias de Informação e Comunicação abordaremos antes sobre o conceito de tecnologias.

Kenski (2008) afirma que as tecnologias são o uso do raciocínio do homem quando são postas em prática, dando origem a diferentes equipamentos, instrumentos, recursos, produtos, processos e ferramenta.

Para o senso comum é o estudo sobre técnicas, processos, métodos, meios e instrumentos de um ou mais ofícios ou domínios da atividade humana.

Nesse sentido, conforme as necessidades surgiram, o homem lançou mão de sua capacidade racional para desenvolver novas tecnologias e canais para a comunicação.

As ferramentas de comunicação são técnicas e formas de linguagem que foram evoluindo com o passar da história e são através delas que hoje se desenvolvem várias formas de gestão e comunicação entre os grupos, empresas e comunidades.

TICs são ferramentas de trabalho dos professores, empresários, publicitários, jornalistas, comunicadores e tantos outros, que aproveitam destes meios em diversos campos de atividade.

As TICs são tecnologias usadas para informação e servi de meio na comunicação, envolvendo hardware de computadores, redes, celulares, softwares de busca e navegação, documentos colaborativos como o Google docs., ferramentas de conferência audiovisuais. Correspondem a todas as tecnologias que interferem e mediam os processos informacionais e comunicativos.

Pode-se dizer que TICs são um conjunto de recursos tecnológicos que, se estiverem integrados entre si, podem proporcionar a 
automação e a comunicação de vários tipos de processos existentes nos negócios, no ensino e na pesquisa científica, na área bancária e financeira, ou seja, são tecnologias usadas para reunir, distribuir e compartilhar informações, como exemplo: sites da Web, equipamentos de informática (hardware e software), telefonia, quiosques de informação e balcões de serviços automatizados.

Com a evolução dos hardwares e softwares foi assegurado à instrumentalização da comunicação e dos processos decorrentes em meios virtuais. Mas verdadeiramente foi a popularização da internet que colocou de vez o uso das TICs em diversos campos inclusive a educação.

Por meio da colaboração, profissionais que se encontram distantes geograficamente trabalham em equipe. As trocas de informações geram novos conhecimentos e competências entre os profissionais abrindo novo horizonte, novas perspectivas, novas soluções.

A área da educação pode tirar proveito das TICs, dar saltos de qualidade e criatividade, tudo em nome de uma nova maneira de ver o mundo e isso irá fortalecer-se, desde a educação básica até a pesquisa científica, passando pelo ensino a distância (Alexandre, 2008).

Moran (2007) Diz que as tecnologias digitais hoje são muito acessíveis, instantâneas e podem ser utilizadas para se aprender em qualquer lugar, tempo e de múltiplas formas.

As tecnologias na educação são mais do que recursos didáticos, ampliam e modificam a forma de mediação na relação professor e aluno, ensinar e aprender causa uma ruptura com o pensamento hierárquico dessa relação e, portanto, permite ao aluno construir seu próprio conhecimento com um material vasto disponível, como Whatsapp Hotmail, twitter, instagran para interagir com práticas educacionais.

A escola deve fornecer experiências pedagógicas aos estudantes para construir e produzir esta tecnologia mental colaborativa. Kensk 2008 enfatiza que: a escola deve assumir o papel de capacitar os cidadãos para a complicação do mundo e os desafios que ele propõe, preparar cidadãos conscientes para lidar criticamente com informações e mudanças excessivas, para lidar com inovações e sucessivas transformações de conhecimento em todas as áreas. 


\section{FORMAÇÃO DE PROFESSORES}

É fundamental que o professor esteja em constante processo de formação, buscando sempre a nova maneira de aprimorar as suas práticas pedagógicas, pois com esta busca constante pela capacitação continuada ele será capaz de melhorar sua prática pedagógica considerando a sua trajetória pessoal, pois a carreira profissional do educador também se relacionada à sua vida pessoal, assim ele seguirá em procura das suas realizações enquanto professor. Para Moran a mudança na educação depende basicamente da boa formação dos professores:

\footnotetext{
Bons professores são as peças-chave na mudança educacional. Os professores têm muito mais liberdade e opções do que parece. A educação não evolui com professores mal preparados. Muitos começam a lecionar sem uma formação adequada, principalmente do ponto de vista pedagógico. Conhecem o conteúdo, mas não sabem como gerenciar uma classe, como motivar diferentes alunos, que dinâmicas utilizar para facilitar a aprendizagem, como avaliar o processo ensino-aprendizagem, além das tradicionais provas (MORAN, 2007, p.18).
}

A formação está ligada ao desenvolvimento do ensino, e da profissão docente. A formação de professores traz aspectos importantes que constituem o ser professor. Para Alves (1991), a formação permanente dos professores tem como objetivos: possibilitar a participação do professor na organização dos processos de formação; satisfazer as necessidades do professor enquanto indivíduo; ampliar o campo das experiências profissionais do professor; e prepará-lo para a mudança e eficácia.

Quando se conjectura o trabalho do Professor, imediatamente imagina ele em frente a uma turma de alunos utilizando um quadro negro e giz expondo um conteúdo, aplicando atividades, textos de leitura, buscando a forma mais elementar possível, simplificar o conteúdo na intenção de que o aluno aprenda a proposta em questão, Diante do exposto discorreremos agora sobre a formação dos docentes para se tornarem capazes de dominar a tecnologia da informação e comunicação, pois como afirmara Piaget: 
A principal meta da educação é criar homens que sejam capazes de fazer coisas novas, não simplesmente repetir o que outras gerações já fizeram. Homens que sejam criadores, inventores, descobridores. A segunda meta da educação é formar mentes que estejam em condições de criticar, verificar e não aceitar tudo que a elas se propõe (Piaget, 1982, p. 246). . .

Relacionando o exposto observamos que o dito vai ao encontro do programa do Governo Federal PROINFO que tem como propósito disponibilizar para toda a sociedade escolar, formação dos professores acerca das novas tecnologias, bem como realizar análises e reavaliações do processo de implantação do programa nas escolas. Outra objetiva é desenvolver novas habilidades em todo o âmbito escolar, desenvolver novas formas de ensinar a leitura e a escrita, desenvolver dinâmicas de trabalho em equipe entre os profissionais da escola,

Temos como exemplo no programa o professor multiplicador que é responsável por capacitar professores de escolas para o uso da telemática em sala de aula: adota-se no Programa, portanto, o princípio professor capacitando professor.

Os multiplicadores capacitam os professores das escolas nas bases tecnológicas do Proinfo nos estados os Núcleos de Tecnologia Educacional (NTE) que são estruturas descentralizadas de apoio ao processo de informatização das escolas, auxiliando tanto no processo de planejamento e incorporação das novas tecnologias, quanto no suporte técnico e capacitação dos professores e das equipes administrativas das escolas.

O ProInfo É desenvolvido Pela Secretaria de Educação a Distância (SEED), por Meio do Departamento de Infra - Estrutura Tecnológica (DITEC), em Parceria com as Secretarias Municipais e Estaduais de Educação. O Programa funciona de forma descentralizada, Sendo que cada Unidade da Federação existe uma má Coordenação Estadual do Proinfo, cuja principal atribuição é de introduzir o uso das Tecnologias de Informação e Comunicação nas escolas da rede.

\section{PESQUISAS DE CAMPO}

Esta pesquisa foi baseada nas observações feitas no estágio supervisionado IV do Curso de Licenciatura em Computação da Universidade Federal do Semiárido UFERSA na cidade de Mossoró RN, 
ela mostrará como estão sendo utilizadas as tecnologias de informação e comunicação no ambiente escolar, como elas estão sendo utilizadas no processo de aprendizagem dos alunos, e verificar como está o nível de conhecimento dos professores sobre esta temática, através de uma pesquisa de campo realizada em uma escola pública municipal, que conta em sua estrutura física, dez Salas de aula, dois banheiros, um bebedouro, 01 laboratório de informática com 13 computadores.

A introdução de recursos tecnológicos na sala de aula requer planejar como inserir as TIC adequadamente para facilitar o processo didático-pedagógico da escola, buscando uma aprendizagem significativa e melhorando o desempenho de todo o sistema educacional, onde as tecnologias são empregadas eficiente e efetivamente.

As tecnologias que a escola possui são: Uma sala de informática, um auditório informatizado, computadores, retroprojetores, tevê, aparelho de DVD, aparelho de som, microfone, máquina de Xerox, impressoras, data show, internet, telefones.

$\mathrm{Na}$ direção faz se uso de impressora, telefone e computador integrado à internet, pois, tudo que diz respeito a assuntos burocráticos da escola é informatizado. Na Coordenação tem um computador desktop e um notebook, uma impressora, na Secretaria dispõe de dois computadores desktop e um notebook, uma impressora, uma máquina de Xerox, essas tecnologias são frequentemente utilizadas, já que tudo é informatizado.

Já o professor recorre a objetos educacionais digitais, como, animações, imagens, televisão e o vídeo/DVD para dar suporte às aulas,

Moran (2000, p.39-40) apresenta algumas propostas de utilização da televisão e do vídeo na educação escolar: "Inicia por vídeos mais simples; vídeo como sensibilização; vídeo como ilustração; vídeo como simulação; vídeo como conteúdo de ensino; vídeo como produção; vídeo integrando o processo de avaliação; televisão/ "Vídeo-espelho".

Os docentes estimula a pesquisa dos alunos na internet, como encontrar a informação desejada de forma segura e a partir de fontes confiáveis. As TICs que eles mais utilizam para a realização de suas as atividades em se tratando dos hardwares são: Os PC no laboratório 
de informática, TV, som, microfone, DVD, retroprojetor e datashow, o software utilizados com frequência é: ABC - Blocks - Alfabeto móvel Anagramarama - Jogo para treinamento de digitação, Kanagrama - Ordenação de palavras, KhangMan - Jogo da forca, Klettres - Aprendizado do alfabeto a partir de sons de letras e sílabas, KTurtle - aplicativo do tipo LOGO.

De acordo com Moran,

Cada vez mais poderoso em recursos, velocidade, programas e comunicação, o computador nos permite pesquisar, simular situações, testar conhecimentos específicos, descobrir novos conceitos, lugares, ideias. Produzir novos textos, avaliações, experiências. As possibilidades vão desde seguir algo pronto (tutorial), apoiar-se em algo sem desenhado para complementá-lo até criar algo diferente, sozinho ou com outros. (MORAN, 2000, p.44)

O auditório possui DVD, TV, microfones, retroprojetores, data show e ar condicionado. O laboratório de informática: possui um retroprojetor e treze computadores que de acordo com o coordenador estão todos integrados à internet, mas não estão sendo usados, livremente porque a escola não possui um profissional para este espaço, sendo usada quando o professor vem com os estudantes de pesquisa.

Demo (2008), sobre as Tecnologias de Informação e Comunicação, aponta: "Toda proposta que investe na introdução das TICs na escola só pode dar certo passando pelas mãos dos professores. O que transforma tecnologia em aprendizagem, não é a máquina, o programa eletrônico, o software, mas o professor, em especial em sua condição socrática.".

Para verificação de conhecimento dos professores sobre as TICs Na instituição, foi feito uma pesquisa para coleta de dados e esta coleta se consistiu na produção de um questionário que foi aplicado junto aos professores.

Sobre a estrutura do questionário, foram elaboradas três questões, fechadas. Os enunciados buscaram em seu contexto investigar sobre o conhecimento, formação e uso das TICs. Os questionários foram aplicados pessoalmente na referida escola entre um período de duas horas do dia 24 de novembro de 2017, Os dados extraídos 
dos questionários foram organizados em gráficos no formato de pizza, utilizando porcentagem e para cada questão há um do gráfico.

Dentre os questionamentos, um dos mais relevantes se trata do conhecimento dos participantes sobre as TICs. Com os dados obtidos, $100 \%$ dos participantes, ou seja, todos. Possuem algum conhecimento frente a essas tecnologias. Esses dados nos apresentam a dimensão e proporção das TICs no contexto educacional atual, comprovando o que se tinha observado anteriormente.

A segunda indagação, sendo objetiva e com duas alternativas, consiste em saber se eles, os professores possuíam formação pelo Proinfo. Os cursos ajudam os professores a desenvolver metodologias inovadoras e até a dar suporte aos alunos que dele necessitem na preparação de trabalhos. "Esses conhecimentos servem para melhorar a qualidade das aulas e também o aprendizado dos alunos", (Schenini, 2013) a resposta pode ser observada no gráfico 1 abaixo.

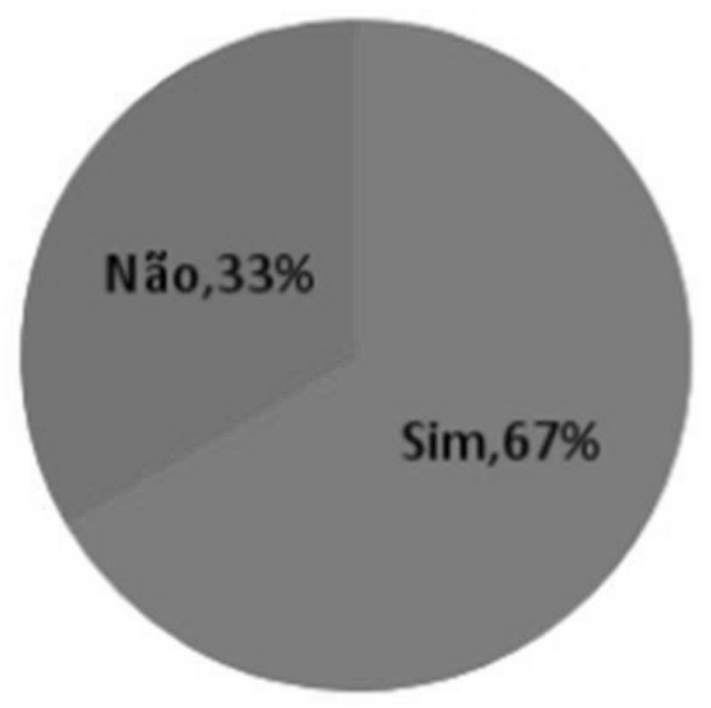

Gráfico 1: Professor com formação no ProInfo

Fonte: Dos autores (2018)

Conforme podemos perceber, $67 \%$ dos docentes possuem capacitação, enquanto 33\% não estão capacitados, fazendo ver que no quesito formação de professores no Pronto a escola está bem à frente das outras da cidade. 
A terceira, sendo também objetiva e com duas alternativas, consiste em saber se eles, os professores, faziam uso da TICs em suas práticas pedagógicas, conforme pode ser observado no gráfico 2 .

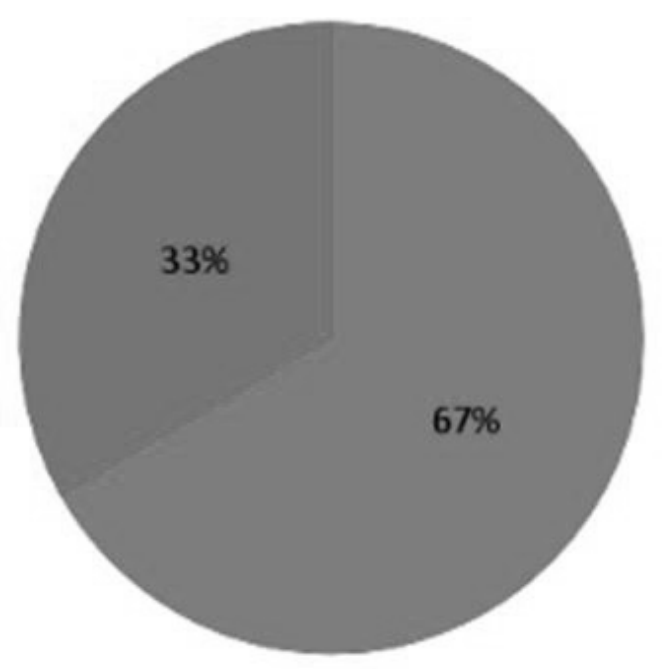

Gráfico 2: Professor com formação no ProInfo 2

Fonte: Dos autores (2018)

Conforme observado no terceiro gráfico onde temos a verificou-se que $67 \%$ dos professores usam as ferramentas tecnológicas em ambiente escolar enquanto a minoria 33\% deixa de usar, portanto fica evidente o comprometimento dos professores do Colégio Evangélico Leôncio José de Santana na Cidade de Mossoró, no sentido utilizam as TICs em suas práticas pedagógicas.

\section{VANTAGENS DE SE TER UM PROFESSOR PREPARADO TECNOLOGICAMENTE}

Podemos citar vários benéfico que uma escola pode ter em razão de ter em seu quadro funcional professores preparado tecnologicamente, eles desenvolvem ou ajudam a desenvolver metodologias inovadoras e dar suporte aos alunos que dele necessitem na preparação de trabalhos. Estes professores capacitados usam Esses seus conhecimentos para melhorar a qualidade das aulas e também 
o aprendizado dos alunos, eles deixam as aulas mais atrativas, deste modo, o aluno melhora na aprendizagem. Aqueles alunos que não demonstravam interesse passaram a trabalhar mais em grupo, a pesquisar e a ter mais participação nas aulas.

$\mathrm{Na}$ escola pesquisada podemos apontar vários benefícios adquiridos por se ter pedagogo bem preparado, dentre eles a escola já foi duas vezes vice-campeão do prêmio de qualidade, também nos últimos anos vem se destacando no Índice Desenvolvimento da Educação Básica IDEB Superando os noves Capitais dos Estados do Nordeste. (Cadastro, 2015)

Portanto sabe-se que o uso adequado das TICs possibilita ao professor a escolha de objetos de estudos diferenciados, de acordo com as necessidades e desejos do aluno, despertando o conhecimento e senso crítico sobre diversos assuntos, facilitando assim o trabalho e manuseios das informações.

Com isso observou-se que quando o docente tem conhecimento das TICs e sabe transmitir ou mediá-las aos seus alunos o conhecimento através do seu uso, todo o envolvido na educação sai ganhando.

\section{CONSIDERAÇÕES}

Este trabalho foi realizado com intuito de mostrar qual o impacto das TICs na educação e a relevância que professores bem preparados para usá-las podem Proporcionar a educação

\section{REFERÊNCIAS}

ANDRADE, A. de; LIMA, M. C. M. Albuquerque L. Ligeiras reflexões sobre os principais métodos de tratamento da epilepsia. 1993.

CARVALHO, A. M. P. de (Org.). Formação continuada de professores. São Paulo: Pioneira Thomson Learning, 2003.

GOMES, C. R. A.; GOMES, A. S.; ARAÚJO, C. A. O que me constitui professor?: análise da mudança da prática docente em relação ao uso de tecnologias digitais no ensino.

DEMO, P. TICs e educação. 2008. Disponível em: <http://www.pedrodemo.sites.uol.com.br>. 
MORAN, J. M. Novas tecnologias e mediação pedagógica. 6. ed. Campinas: Papirus, 2000.

MORAN, J. M. A educação que desejamos: novos desafios e como chegar lá. Papirus Editora, 2007.

NUÑEZ, I. B. O livro didático para o ensino de ciências. Selecioná-los: um desafio para os professores do ensino fundamental. Encontro Nacional de Pesquisa em Educação em Ciências, v. 3, p. 88-89, 2001. PIAGET, J. O nascimento da inteligência na criança. 4. Ed. Rio de Janeiro: zahar, 1982.

RODRIGUES, A. de J. Metodologia científica: completo e essencial para a vida universitária. São Paulo: Avercamp, 2006. 
REDE COLABORATIVA DE INOVAÇÃO TECNOLÓGICA NA EDUCAÇÃO: COMPARTILHANDO CONHECIMENTOS A PARTIR DA APRENDIZAGEM NA ERA DIGITAL

Querte Mehlecke

Neferson Barbosa da Silva Ramos

Maria Auxiliadora Soares Padilha

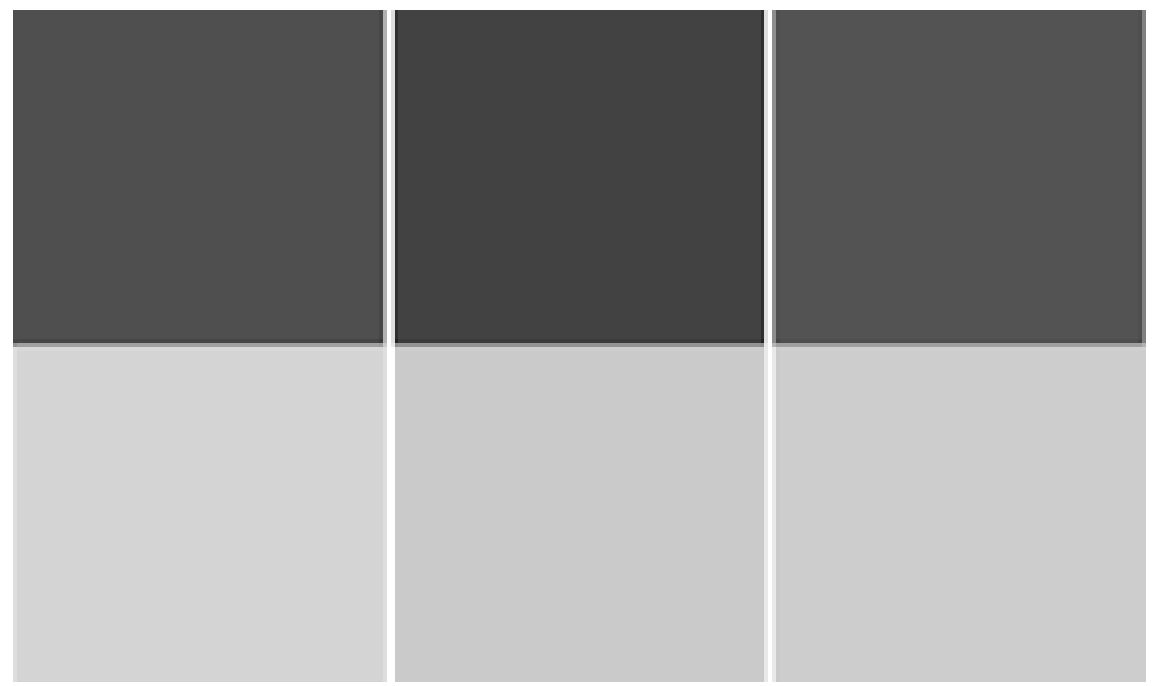




\section{INTRODUÇÃO}

Este estudo apresenta uma pesquisa sobre o uso de uma Rede Colaborativa de Inovação Tecnológica na Educação, a qual tem por objetivo compartilhar projetos de pesquisas desenvolvidos por alunos do Programa de Pós-Graduação em Educação Matemática e Tecnológica - EDUMATEC, UFPE. A metodologia utilizada é um estudo de caso baseado no desenvolvimento de um portal para o compartilhamento de projetos inovadores de pesquisas relacionados com as tecnologias digitais, metodologias ativas e coreografias didáticas. O aporte teórico está embasado em Borges (2014), Christensen (2015), Bakthin (2000), Lévy (1999), Morin (1999), Moran (2012; 2013; 2017), Mitre (2008), PADILHA (2017; 2018), dentre outros. Os resultados da pesquisa estão evidenciados no portal desenvolvido para a inclusão de projetos inovadores.

A geração atual vive conectada e, muitas vezes, percebemos que os docentes deixam de utilizar os recursos tecnológicos em sala de aula, ora por desconhecer recursos que possam contribuir para o processo de ensino e aprendizagem, ora por não saber e não ter o pertencimento das tecnologias digitais, não sabendo, muitas vezes, como as utilizar a favor da aprendizagem.

Ao pensar em como contribuir para que os docentes possam sentir-se motivados e atraídos pela tecnologia, em sala de aula, surge o projeto "Rede colaborativa de inovação tecnológica na educação". Este projeto representa uma proposta de rede colaborativa a qual disponibilizará relatos de experiências dos projetos de pesquisa quanto ao uso dos recursos tecnológicos, em sala de aula, metodologias inovadoras, bem como servir de repositório para boas práticas do uso das tecnologias digitais e da prática docente em sala de aula. Essa rede nasceu a partir de uma proposta de projeto para a realização do "pós-doc". Inicialmente, seu uso está restrito aos alunos de mestrado e doutorado do Programa de Pós-Graduação em Educação Matemática e Tecnológica - EDUMATEC, UFPE, programa em que a pesquisadora está inserida.

O objetivo deste projeto é incentivar a participação e divulgação dos projetos de pesquisa inovadores, no tocante ao uso das tecnologias educacionais em sala de aula, na Rede colaborativa en- 
tre as instituições de ensino, inicialmente no grupo de pesquisa do EDUMATEC, e, depois, abrir para as instituições de ensino do Brasil e do exterior.

O novo repensar da sala de aula, a metodologia, a inovação pedagógica e as tecnologias digitais, necessitam de reflexão, de ações dos docentes e do pensar sobre o quê e como as tecnologias digitais estão sendo utilizadas na educação. Ainda, preocupar-se com as competências que este aluno irá necessitar desenvolver, no decorrer do seu processo formativo, debruçando-se sobre as diferentes possibilidades do fazer docente em sala de aula e do voltar-se ao aluno para que ele possa construir seu conhecimento com novo aporte metodológico e por meio de recursos tecnológicos que o instiguem, provoquem e que venham despertar sua curiosidade, autonomia e engajamento com o seu aprendizado.

Neste sentido, o Projeto Rede colaborativa, busca enfatizar a utilização de um formato de compartilhamento de projetos desenvolvidos pelos alunos do Programa de Pós-Graduação em Educação Matemática e Tecnológica - EDUMATEC, UFPE, por meio de um Web Portal. De modo geral, os alunos participam das aulas, apresentam e participam de seminários e encontros com a orientadora para discutir o projeto. Quando iniciam o desenvolvimento da pesquisa, dando início ao projeto, começam a surgir dúvidas, falta inspiração e, nessa inquietação, a Rede colaborativa pode ser uma fonte de inspiração e pesquisa para este e outros alunos do programa EDUMATEC.

\section{FUNDAMENTANDO O ESTUDO}

A análise das tecnologias educacionais utilizadas pelos docentes, e disponibilizados na Rede, terá como referência a literatura que trata do desenvolvimento e aplicabilidade de metodologias inovadoras, em sala de aula.

O aporte teórico está embasado em Borges (2014), Christensen (2015), Bakthin (2000), Lévy (1999), Morin (1999), Moran (2012, 2013 e 2017); Mitre (2008); PADILHA (2017 e 2018), dentre outros estudiosos, que fundamentaram o projeto de pesquisa através dos conceitos de: tecnologias educacionais, inovação tecnológica 
e redes colaborativas. A partir dos conceitos destacados, salienta-se que as atividades propostas, à luz de conceitos de Bakthin (2000), podem ser mais diversificadas e dialógicas, podendo propiciar um percurso mais significativo, tanto para os trabalhos em grupo quanto individuais. Nesse sentido, a Rede propiciará o compartilhamento de informações sobre as tecnologias inovadoras utilizadas ou que poderão ser utilizadas, na sala de aula.

Deste modo, destaca-se a fala de Lévy (1999, p. 17) que, na época, já dizia que não queria, de forma alguma, “[...] dar a impressão de que tudo o que é feito com as redes digitais seja "bom". Isso seria tão absurdo quanto supor que todos os filmes sejam excelentes. Peço apenas que permaneçamos abertos, benevolentes, receptivos em relação à novidade". Nesta linha, propõe-se, através deste projeto, apresentar um recurso adicional em favor dos docentes, focalizando-o no processo de ensino e aprendizagem dos alunos.

Há um compromisso, desta feita, com o repensar as tecnologias adotadas em sala de aula, a partir de reflexões dos docentes quanto ao aprendizado dos alunos, que possibilitem a articulação e a (re)organização do conhecimento. Morin (1999, p. 39) reforça esta ideia quando afirma que há que se reformar o pensamento de modo paradigmático:

Para articular e organizar os conhecimentos e assim reconhecer e conhecer os problemas do mundo é necessário uma reforma do pensamento. Ora esta reforma é paradigmática e não programática: é a questão fundamental para a educação porque ela respeita à nossa aptidão em organizar o conhecimento.

O conhecimento, segundo Morin (1999), a partir das informações ou dados isolados, não faz sentido. Para que haja sentido é necessário situar as informações e os dados em um contexto. Assim, o repensar docente só fará sentido na construção do conhecimento se estiver contextualizado. Deste modo, cabe ressaltar que as diferentes tecnologias utilizadas pelo docente devem ser compartilhadas; devem estar contextualizadas, explicadas para que outros docentes, em seus contextos específicos, possam repensá-las, adaptá-las e aplicá-las. Esse novo aplicar em contextos diferentes irá gerar novas ações e resultados. E essas ações compartilhadas irão contribuir para que 
o processo de ensino e aprendizagem faça sentido, mesmo que em contextos diferentes.

Colaborando, Padilha e Zabalza (2016, p. 839), afirmam que a

A docência universitária (ZABALZA; ZABALZA, 2010), didática universitária (ZABALZA, 2007), pedagogia universitária (CASTANHO, 2000) passaram a ser, nos últimos anos, objetos de estudo mais discutidos na academia e muitos professores tornaram-se mais sensíveis quanto à necessidade de pensar a docência como uma atuação profissional com características próprias e distintas e que necessita de formação específica para exercê-la.

Assim posto pelos autores, destaca-se que o elo entre a inovação pedagógica e a Rede colaborativa está na divulgação dos projetos, nas trocas e nas discussões de cada um que insere o seu trabalho e comenta o do colega. Neste cenário, onde praticamente todos são professores participam, a colaboração é um fator que enriquece a aprendizagem e as trocas de informações e ideias inovadoras. Neste sentido, Zabalza e Padilha (2016, p. 844) contribuem ao dizer que,

Sendo assim, criar um cenário integrando as tecnologias digitais - TD para coreografias didáticas inovadoras não é uma atividade simples, considerando todas as dimensões necessárias para isso e a complexidade de variáveis que os professores precisam ter em conta para essa montagem.

Mas afinal, o que são coreografias didáticas?

Para responder a esta questão, Padilha e Zabalza (2016, p. 844) dizem que,

O cenário é o espaço, presencial ou virtual, onde a história acontece. Para escrever a coreografia, o coreógrafo planeja o cenário e como a dança irá ocorrer nesse espaço, físico ou virtual. Ele é composto por cores, texturas, móveis e artefatos de um modo geral que estão dispostos de maneira estratégica para dar sentido à cena e também aos personagens. Os dançarinos, e até mesmo o público, interagem com o cenário e seus artefatos. Da mesma forma, na coreografia didática o professor precisa pensar sobre o cenário da aprendizagem de maneira estratégica, pois este está muito variado e os alunos, hoje, influenciam mais na escolha dos componentes desse espaço do que em outros tempos. 
Neste viés, a Rede de colaboração dos alunos do Programa de Pós-Graduação em Educação Matemática e Tecnológica - EDUMATEC, UFPE, voltada para o compartilhamento de projetos e propostas de mestrados e doutorados, se apresenta em um cenário de inovação pedagógica, onde as coreografias didáticas ilustram os cenários e o movimento intelectual deixa de ser individualizado e passa a ser compartilhado.

A educação está sendo cada vez mais valorizada na sociedade e a academia passa a ser um espaço privilegiado em que, através do processo de ensino e aprendizagem, pode-se discutir refletir e contribuir para o desenvolvimento do ser humano consciente de sua inserção no meio acadêmico e social.

Desta forma, o docente reforça o seu papel, o qual irá repercutir positivamente nas ações praticadas em sala de aula, por meio de técnicas de ensino e recursos tecnológicos inovadores. Em decorrência, passa a refletir sobre a sua docência, instância essa que deverá contribuir para que o aluno obtenha as competências traçadas para o seu curso.

Considerando a prática docente como uma ação metodológica, é fundamental para o desenvolvimento do aprendizado dos alunos que os docentes utilizem tecnologias educacionais inovadoras, que propiciem o desenvolvimento das competências e habilidades dos alunos. Segundo Zabalza (2006), os processos de aprendizagem dos estudantes estão fortemente relacionados com os métodos de ensino dos professores. Neste sentido, justifica-se este projeto em que cada docente compartilhe suas ações metodológicas, práticas de ensino imbricadas em estratégias voltadas para a sala de aula, seja essa presencial seja a distância, com o intuito de compartilhar as tecnologias inovadoras utilizadas.

\section{CENÁRIO DE ESTUDO}

A metodologia utilizada é estudo de caso, segundo Cervo (2007, p. 78), “[...] é a pesquisa sobre determinado indivíduo, família, grupo ou comunidade que seja representativo de seu universo[...]." E é na representatividade e na formação continuada de docentes que este estudo de caso é evidenciado. O universo da pesquisa são todos 
os alunos do Programa de Pós-Graduação em Educação Matemática e Tecnológica - EDUMATEC, UFPE, PE.

Neste cenário, onde a pesquisa configura-se como um estudo de caso, com análise temática dos dados empíricos, gerados pelos alunos do programa, a partir da inserção de seus projetos e pesquisas no portal da Rede colaborativa, cada aluno recebe um usuário e senha para inserir seus projetos, modificar e comentar o projeto dos demais colegas. Inicialmente, o administrador do sistema insere os primeiros projetos e cadastra os usuários. A partir da inserção dos projetos de pesquisa, que envolvem inovação pedagógica, metodologias ativas, tecnologias digitais e coreografias didáticas, os dados serão coletados a partir da criação da rede e das tecnologias inovadoras compartilhadas e utilizadas em sala de aula.

Os métodos e as técnicas utilizadas para o alcance dos objetivos propostos neste estudo baseiam-se nos estudos de Borges (2014), Christensen (2015), Bakthin (2000), Lévy (1999), Morin(1999), Mitre (2008), Padilha e Zabalza (2016), entre outros estudiosos que teoricamente fundamentam o projeto de pesquisa.

De acordo com Borges (2014, p. 120), pode-se entender metodologias como

[...] formas de desenvolver o processo do aprender que os professores utilizam na busca de conduzir a formação crítica de futuros profissionais nas mais diversas áreas. A utilização dessas despertando a curiosidade, estimulando tomadas de decisões individuais e coletivas, advindos das atividades essenciais da prática social e em contextos do estudante.

Ao tomar consciência de que aprendizagem mediada pelas tecnologias inovadoras percebemos que diversos fatores influenciam na organização de um cenário ou ambiente de aprendizagem, seja ele presencial ou virtual (PADILHA e ZABALZA, 2016), contudo é um instrumento necessário e significativo para ampliar suas possibilidades e caminhos, o aluno, neste cenário, poderá exercitar a liberdade e a autonomia na realização de escolhas e na tomada de decisões (CYRINO; TORALLES-PEREIRA, 2004).

Neste sentido, o presente estudo possibilitará a participação e integração dos alunos convidados a incluir seus projetos, compar- 
tilhando as diferentes tecnologias educacionais e metodologias ativas conectadas com as coreografias didáticas para refletir em grande grupo, o seu uso.

\section{REFLEXÕES}

Planejar, pensar, refletir e colocar em prática um projeto, requer, antes de tudo, objetivo claro, metodologia, aporte teórico, plano de ação e resultados esperados. E, ao chegar no final deste estudo, percebe-se que a sua utilização, a qual ainda está no começo, pode ser um espaço de colaboração entre os alunos de cursos de Pós-Graduação Stricto Sensu e demais pesquisadores.

A proposta da Rede colaborativa trouxe para o grupo de pesquisas do EDUMATEC um espaço de colaboração, em que a troca pode ocorrer a qualquer momento. Ainda, ser um espaço onde o pesquisador não se sente sozinho, sente-se acompanhado e acolhido pelos demais colegas de estudos.

Ao se pensar em coreografias didáticas, metodologias ativas, tecnologias digitais inovadoras e o processo de Rede colaborativa, verifica-se que uma se encontra conectada a outra, que se complementam, levando o aluno ao encantamento de se ver em relação com o outro, vendo seu projeto conectado ao projeto do colega.

A partir dessas reflexões, chega-se ao consenso de que as redes podem contribuir para o processo de ensino e aprendizagem mediado pelas Tecnologias de Informação e Comunicação Digital, e, essas, compartilhadas e interconectadas, possibilitam a outros docentes e alunos refletir, discutir, divulgar e compartilhar suas experiências.

\section{REFERÊNCIAS}

BAKHTIN, M. Estética da criação verbal. São Paulo: Martins Fontes, 2000.

BORGES, Tiago Silva; ALENCAR, Gidélia. Metodologias ativas na promoção da formação crítica do estudante: o uso das metodologias ativas como recurso didático na formação crítica do estudante do en- 
sino superior. Cairu em Revista. Jul/Ago 2014, Ano 03, nº 04, p. 1 19143 , ISSN 22377719. Disponível em: < http://www.cairu.br/revista/ arquivos/artigos/2014_2/08\%20METODOLOGIAS\%20ATIVAS\%20 NA\%20PROMOCAO\%20DA\%20FORMACAO\%20CRITICA \%20 DO\%20ESTUDANTE.pdf>. Acesso em: 30 abr. 2019.

CYRINO, EG, TORALLES-PEREIRA ML. Trabalhando com estratégias de ensino-aprendizado por descoberta na área da saúde: a problematização e a aprendizagem baseada em problemas. Cad Saúde Pública, Rio de Janeiro, 2004;20(3):780-788.

DIESEL , Aline; MARCHESAN, Michele Roos; MARTINS,Silvana Neumann. Metodologias ativas de ensino na sala de aula: um olhar de docentes da educação profissional técnica de nível médio. Disponível em: http://www.univates.br/revistas/index.php/signos/article/ viewFile/1008/995. Acesso em: 30 abr. 2019.

MITRE, Sandra Minardi et al. Metodologias ativas de ensino-aprendizagem na formação profissional em saúde: debates atuais. Ciênc. Saúde coletiva, Rio de Janeiro, v. 13, supl. 2, p. 2133-2144, Dec. 2008. Disponível em: <http://www.scielo.br/scielo.php?script=sci_arttext\&pid=S1413-81232008000900018\&lng=en \&nrm=iso $>$. Acesso em: 30 abr. 2019. http://dx.doi.org/10.1590/S1413-81232008000900018. MORAN, José Manuel. A educação que desejamos: novos desafios e como chegar lá. 5. ed Campinas: Papirus, 2012.

MORAN, José Manuel. Novas tecnologias e mediação pedagógica (em colaboração com MASETTO, Marcos \& BEHRENS, Marilda). 21. ${ }^{a}$ ed., São Paulo: Papirus, 2013.

MORIN, Edgar. Os sete saberes para a educação do futuro. Lisboa: Instituto Piaget Divisão Editorial, 1999.

VALENTE, J. Valente. Disponível em: <http://www.scielo.br/pdf/er/ nspe4/0101-4358-er-esp-04-00079.pdf>. Acesso em: 30 abr. 2019.

PADILHA, Maria Auxiliadora Soares; ZABALZA, Miguel Angel. Um cenário de integração de tecnologias digitais na educação superior: em busca de uma coreografia didática inovadora. Revista e-Curriculum, São Paulo, v.14, n.03, p. 837 - 863 jul./set.2016, e-ISSN: 1809-3876 Programa de Pós-graduação Educação: Currículo - PUC/SP. Disponível em: <http://revistas.pucsp.br/index. $\mathrm{php} /$ curriculum $>$ Acesso em 20 de setembro de 2018. 
SOBRE OS AUTORES

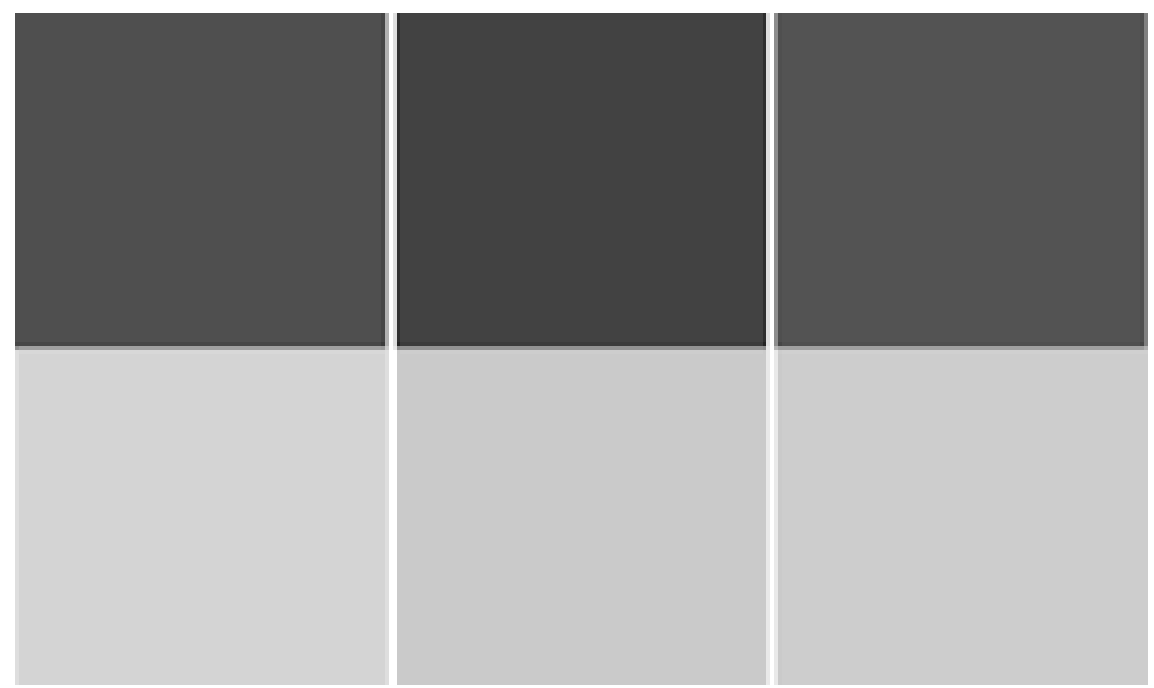




\section{Ana Karine das Chagas Vieira}

Formação Acadêmica Possui graduação em Pedagogia pela Universidade do Estado do Rio Grande do Norte, concluiu em 2001. Pós-graduação em Psicologia Escolar e da Aprendizagem pela Faculdade Integrada de Patos PB(FIP), concluiu em 2009 e em Atendimento Educacional Especializado AEE pela UFERSA concluído em agosto de 2016. Tem curso de aperfeiçoamento em Atendimento Educacional Especializado . Com experiência na área de Educação desde 1999 na Educação Infantil e Ensino Fundamental, ainda como professora de graduação e pós graduação pela CEAPE, FALC, IFET e FVJ desde 2011 e como tutora presencial da disciplina História e educação no polo de Grossos pela UFERSA no semestre 2014.2 e no polo de Natal em 2015.1 e 2017.1 e como tutora a distância novamente na UFERSA da disciplina Curso preparatório em EAD e Introdução em Educação a Distância no curso de matemática 2017.3, em 2018.1, Tutora da disciplina Introdução em EAD, em 2018.2 tutora em Política, Estrutura e Gestão da educação.Possui experiência em Coordenação Pedagógica No Centro de Referência da Assistência Social-CRAS do município de Grossos de Junho de 2013 a dezembro de 2017, Coordenadora Pedagógica e supervisora de estágio acadêmico nas turmas de graduação em Pedagogia de janeiro de 2017 a 2018(prestadora de serviços) E atualmente como professora efetiva de AEE na Escola Municipal Julita Alves no município de Areia Branca, desde 2015 e Coordenadora Pedagógica (Bolsista CAPES) do NEaD Ufersa desde 10/2018 até os dias atuais. Já ministrei algumas palestras na área de Educação Infantil,Ensino Fundamental, Educação Especial, Inclusão e Educação à Distância. Participo atualmente como Pedagoga do Projeto de Extensão ROBOT em Ação (parceria da UFERSA, PETROBRAS).

\section{Antônio Soares de Oliveira Filho}

Possui graduação em Matemática (Ufersa), bacharel em Teologia e licenciado em ciências da Religião pelo Instituto Superior de Teologia Aplicada (2008). Curso técnico na Escola Técnica Federal do Rio Grande do Norte ? ETFRN (1996); sou professor da rede pública Estadual em Matemática, ministrei aulas no ensino fundamento II e EJA na escola Estadual Ambulatório Pe. Dehon. Especialização em Psicopedagogia Institucional pela Fatin, atualmente ministro aulas no Ensino Fundamenta II e no Ensino Médio na Escola Estadual Manoel João. Tive o privilégio também de ser supervisor no PIBID(Ufersa) coordenando alguns colegas do curso de Licenciatura em Ma- 
temática (Ufersa), desenvolvendo um projeto sobre jogos digitais em Matemática. Curso Mestrado na faculdade Interamericana, fase de conclusão, sob orientação da Dra Taniamá Viera Barreto e a co-orientadoras Dra Katia Cilene da Silva, com o seguinte tema de projeto de pesquisa: Tecnologia e História da Matemática como possibilidades didáticas motivadora do ensino da rede pública em Mossoró.

\section{Cláudia Magalhães}

Licenciada em Pedagogia pela Universidade Federal de Pernambuco; Especialista em Arte Educação pela Faculdade Campos Elíseos, Graduanda em Artes Visuais com Ênfase em Digitais pela UFRPE, Pós-graduanda em Arte e Tecnologia também pela mesma instituição. Monitora voluntária do Projeto Brinc@rte.

\section{Cristiane Kessler de Oliveira}

Possui graduação em Relações Públicas pela Universidade do Vale do Rio dos Sinos (2002), pós-graduação (MBA) em Gestão de Negócios, com ênfase em Marketing Estratégico pela Universidade do Vale do Rio dos Sinos (2005) e Mestrado em Educação pela Universidade do Vale do Rio dos Sinos (2011). Atualmente é docente nível superior presencial e EAD nas Faculdades QI.

\section{Danniel Cavalcante Lopes}

Possui graduação em Engenharia de Computação pela Universidade Potiguar (2002), mestrado em Engenharia Elétrica - Pontifícia Universidade Católica do Rio Grande do Sul (2005) e doutorado em Engenharia Elétrica pela Universidade Federal do Rio Grande do Norte (2009). Atualmente é avaliador de cursos do Instituto Nacional de Estudos e Pesquisas Educacionais Anísio Teixeira e professor adjunto III da Universidade Federal Rural do Semi-Árido. Tem experiência na área de Ciência da Computação, com ênfase em Inteligência Artificial.

\section{Enoy Fernandes Pimenta}

Possui Graduação em Licenciatura em Computação pela Universidade Federal Rural do Semi-Árido, Brasil (2019). 


\section{Ernandes Rodrigues do Nascimento}

Diretor Acadêmico, Professor Universitário, Conteudista para EAD, Pesquisador, Procurador Institucional e Avaliador de Cursos (INEP). Experiência com: Direção de IES; Coordenação de Curso Superior; Coordenação Acadêmica de Polo EAD e Tutoria Presencial e Virtual. Foi membro do Grupo de Pesquisa MKP (Centro de Estudos em Marketing e Pessoas) do PROPAD - CCSA/DCA - UFPE durante os anos de 2013 e 2014 e do Grupo de Pesquisa Mídias Digitais e Mediações Interculturais entre os anos 2017 e 2018. Em novembro de 2018 passou a integrar o Laboratório de Pesquisa e Prática - Educação, Metodologias e Tecnologias - Educat, coordenado pela Profa. Maria Auxiliadora Soares Padilha e pelo Prof. Marcos Alexandre de Melo Barros.

\section{João Padilha Moreira}

Mestrando em Ensino de Ciências e Matemática - ULBRA - 2017-1, especialista em formação de professores (QI-2013), especialista em gestão da tecnologia da informação, pelo Curso de Ciência da Computação (UNICRUZ-2006), Comunicólogo (UNICRUZ-2005). Diretor de Ensino na Faculdade Alcides Maya, foi coordenador do curso Superior em Análise e Desenvolvimento de Sistemas-QI. Administrador Plataformas: Moodle, NAVI, Wordpress, Joomla, Concrete, OJS/ SEER, Linguagens de Programação: Pascal, C, Java, Python, HTML5, CSS3, JavaScript, BootStrap, AngularJS, PHP, Arduino, Scratch, GIT e GITHUB, Banco de Dados: MySQL, Postgress, Oracle, MongoDB. Redes de computadores: Protocolo TCP/IP, SNMP, UDP, Ferramentas Gráficas: Photshop, Gimp, Corel, Ilustrator, picasa e editores de vídeo, Sistemas Operacionais: Windows e Linux, Construção de servidores, Máquinas Virtuais e Docker.

\section{Josivania Maria Alves de Freitas}

Pedagoga pelas Faculdades Integradas da Vitória de Santo AntãoFAINTVISA; Especialista em Formação de Educadores pela Universidade Federal Rural de Pernambuco-UFRPE; Psicopedagoga Clínica e Institucional pelo Centro Universitário Internacional UNINTER-SC/ PR; Mestra e Doutoranda em Educação Matemática e Tecnológica, na linha de pesquisa Educação Tecnológica pela Universidade Federal de Pernambuco-PPG EDUMATEC-UFPE. É Coordenadora Pedagógica da Escola Virtual de Formação e Educação na Saúde da Diretoria Executiva de Gestão do Trabalho e Educação na Saúde (DEGTES) Secretaria de Saúde (SESAU) da Prefeitura da Cidade do Recife (PCR); 
Professora Autora e Formadora de Cursos a distância e Online da Secretaria de Educação do Estado de Pernambuco e da Universidade Federal de Pernambuco/ Campus/Agreste, Caruaru-PE de Cursos Técnicos e de Aperfeiçoamento/ Formação Continuada de Professores e Gestores Indígenas em Pernambuco. Docente da Pós-Graduação/ Lato Sensudos Cursos de Docência do Ensino Superior, Neuropsicopedagogia e Gestão Pública com Ênfase em Saúde da Família do Instituto Nacional de Ensino e Pesquisa-INESP/Polo Faculdade Novo Horizonte- Caruaru-PE. Professora da Pós-Graduação em Psicopedagogia Educacional e Educação Especial Inclusiva da Universidade Nabuco - UNINABUCO-Recife-PE e, é Professora do Ensino Fundamental na rede pública de ensino da Prefeitura do Jaboatão dos Guararapes-PJG. É indigenista da origem entre os dois Povos indígenas em Pernambuco/ Fulni-ô e Xukuru. É membro e pesquisadora no Grupo de Pesquisa e Prática Educação, Metodologias e Tecnologias (EDUCAT), da Universidade Federal de Pernambuco (UFPE) e do grupo de pesquisa estilos de aprendizagem e coaprendizagem pelo Departamento de Educação e Ensino a Distância (DEED), da Universidade Aberta de Portugal- (UAB/PT). Atualmente desenvolve pesquisas sobre as seguintes temáticas: estratégias para coaprendizagem na educação superior a distância e online, estilos de aprendizagem e de uso do espaço virtual, metodologias ativas, didática no ensino superior, formação de professores, teorias da aprendizagem para análises psicopedagógicas e inclusivas; avaliação psicopedagógica, produção e prática de projetos para educação escolar indígena em PE.

\section{Kátia Cilene da Silva}

Graduada em Informática pela URCamp, com especialização em Ciência da Computação - URCamp/UFRGS e Gestão Educacional pela URCamp/UFSM. Mestre e doutora em Educação Matemática e Tecnológica - UFPE. Atuou como Diretora dos Cursos Superiores Tecnológicos de Redes de Computadores e de Gestão de Tecnologia da Informação da Faculdade dos Guararapes, sendo responsável pela implantação destes. Como Diretora do Curso de Ciência da Computação, da Faculdade dos Guararapes. Possui experiência anterior em gestão do ensino superior como Coordenadora do Curso de Graduação em Informática da URCamp, campus universitário de Alegrete - RS. Atuou como Coordenadora dos Trabalhos de Conclusão de Curso, do Curso de Ciência da Computação da Faculdade dos Guararapes. Professora da UFERSA desde out/2010, ministrando as disciplinas de Tópicos em Informática, Introdução à Computação, Introdução a lógica, Ambiente Virtual de Ensino Aprendizagem Moodle, 
Introdução à Educação à Distância e Tecnologias Assistivas e tendo coordenado o Subprojeto de Matemática EaD do PIBID. Exerceu as coordenações do Núcleo de Educação à Distância, da Institucional da UAB e do Comitê Institucional de Formação Inicial e Continuada de Profissionais do Magistério da Educação Básica. É professora concursada para a disciplina de Introdução a EaD e Docente orientadora da Residência Pedagógica de Matemática.

\section{Jéssica Ester Frutuoso de Souza}

Possui Ensino Profissional de nível técnico em Técnico em Informática para Internet pelo Instituto Metrópole Digital, Brasil (2016). Graduanda em Ciência da Computação pela Universidade Federal Rural do Semi-Árido - UFERSA. Possui experiência em Educação a Distância no Núcleo de Educação a Distância da UFERSA.

\section{José Wilson Cavalcante Júnior}

Possui Graduação em Licenciatura em Computação pela Universidade Federal Rural do Semi-Árido, Brasil (2019)

\section{Leandro Krug Wives}

Diretor do Centro Interdisciplinar de Novas Tecnologias na Educação (CINTED) da Universidade Federal do Rio Grande do Sul (UFRGS) desde 2017. É Professor Associado no Instituto de Informática da UFRGS. Orientador permanente do PPG em Computação e do PPG em Informática na Educação. Graduado em Ciência da Computação em 1997, pela UCPEL. Mestrado (1999) e Doutorado (2004) em Ciência da Computação, ambos pelo PPGC da UFRGS. Atuou como pesquisador visitante em 2008 no Telecom \& Management SudParis, França. Foi membro da Comissão de Pós-graduação do PPGC durante dois mandatos (2013-2014; 2015-2016). Foi vice-coordenador de duas edições do Curso de Especialização em Informática na Educação para professores do Ensino Básico em modalidade EAD pelo sistema UAB/UFRGS e coordenador de duas edições do Curso de Especialização em Gestão de TI em modalidade semipresencial (2016-2017 e 2017-2018). Participou em duas ocasiões (2011 e 2016) como membro do Comitê Gestor de TI da UFRGS (para a elaboração do PDTI). Foi membro do colegiado do DEPINA por três mandatos (2007-2008; 2011-2012; 20172018). Representante institucional da SBC (2008-2012). Atuou 
em diversos projetos de pesquisa acadêmica (10+), alguns em âmbito de cooperação internacional (4), tendo sido ainda coordenador de um projeto CAPES STIC-AMSUD em parceria com França e Argentina, 2 projetos FAPERGS, um projeto universal CNPQ e um projeto FINEP, de transferência tecnológica. É membro do Laboratório Internacional em Processamento de Alto Desempenho e Informática Ambiente (LICIA), que integra o Instituto de Informática da UFRGS e a Universidade de Grenoble. Como resultado de suas pesquisas, projetos e orientações, publicou mais de 80 trabalhos em eventos, 15 capítulos de livro e 20+ artigos em periódicos. Atua nas áreas de Sistemas de Recomendação, Recuperação de Informações, Big Data Analytics, Mineração de dados (em especial na Web e em textos) e sua aplicação no Ensino a Distância. Associado da Sociedade Brasileira de Computação (SBC) - Associado da Association for Computing Machinery (ACM) - Associado da IEEE Computer Society (IEEE Computer). ORCID:/0000-0002-8391-446X.

\section{Luiz Leonardo Nascimento Denicol}

Diretor Acadêmico da FAQI Gravataí de jan/2017 a mar/2019, Procurador Institucional de 2016 a 2019.Possui graduação em CST em Processos Gerenciais pela Faculdade de Tecnologia de Gravataí, (2008), Especialização em Formação de Professores pela Faculdade de Tecnologia de Porto Alegre (2010) e Esp. em Andamento em Metodologias Ativas (2019). Coordenador do Curso de Processos Gerenciais da FAQI Gravataí de 2013 a 2016. Vice-diretor Acadêmico da FAQI Gravataí de 2016 a 2017. Ministrou aula em Graduação no Eixo de Gestão e Negócios e Pós Graduação em Educação e Gestão. Tem conhecimento e experiência na área de Legislação Educacional Superior, Regulação, Matrizes Curriculares, Projeto de Desenvolvimento Institucional (PDI), Plano Pedagógica Institucional (PPI), Projetos Pedagógicos de Cursos (PPC), Avaliação Institucional, preparação para recebimento de comissões de avaliação do INEP/MEC e gestão do corpo docente, desenvolvimento institucional para melhoria contínua do desempenho dos alunos no ENADE. Experiência em implantação de Educação a Distância, Currículo e Gestão. Possui sólida experiência em processos de credenciamento e recredenciamento institucional junto ao MEC, tanto para modalidade presencial quanto à distância. De de 2010 a 2012 foi professor dos Cursos Técnicos da QI. 


\section{Luiza Helena Felix de Andrade}

Possui graduação em Licenciatura em Matemática pela Universidade Estadual do Ceará (2002), mestrado em Matemática pela Universidade Federal do Ceará (2007) e doutorado em Engenharia de Teleinformática pela Universidade Federal do Ceará (2018). Atualmente é adjunto II da Universidade Federal Rural do Semi-Árido. Tem experiência na área formação de professores de matemática e de Geometria Riemanniana, atuando principalmente em Geometria da Informação.

\section{Marcos Evandro Cintra}

Concluiu recentemente um postdoc na Universidade Federal de São Paulo. É doutor pela USP - ICMC em ciências da computação, Inteligência Artificial e atualmente professor adjunto na UFERSA, Universidade Federal Rural do Semi-Árido, Mossoró, Rio Grande do Norte, desde 2012. Durante o doutorado foi bolsista da FAPESP e fez estágio sanduíche com bolsa CAPES na Universidade de Bristol no Reino Unido (2008 a 2009). É mestre em ciências da computação (2007) pela Universidade Federal de São Carlos - UFSCar com bolsa CAPES. É bacharel em informática pela Universidade de São Paulo - ICMC (2003). É membro da Sociedade Brasileira de Computação desde 2007 e da European Society for Fuzzy Logic and Technology EUSFLAT, desde 2008.

\section{Maria Auxiliadora Soares Padilha}

Possui graduação em Pedagogia, Mestrado e Doutorado em Educação pela Universidade Federal de Pernambuco, e Pós-Doutora pela Universidade de Santiago de Compostela, na Espanha. Pesquisa e atua sobre Coreografias Didáticas e Institucional, Tecnologia Digital da Informação e Comunicação para a educação com ênfase em didática, Inovação Pedagógica e Metodologias Ativas, Educação a Distância, Inclusão Digital, Processos de Ensino e Aprendizagem e Formação de Professores. É professora do Programa de Pós-Graduação em Educação Matemática e Tecnológica da UFPE. Foi coordenadora do Programa Institucional de Inovação Pedagógica,e coordena desde 2011 o Programa de Extensão Proi-Digital da UFPE. 


\section{Michela Melo da Silva}

Graduada em Pedagogia pela Universidade do Estado do Rio Grande do Norte (2006), com mestrado profissional em Ciências da Educação e Multidisciplinariedade pela FACNORTE (2016). Atuei como tutora à distância da Faculdade Estadual do Rio Grande do Norte no curso de letras. Atualmente sou professora das séries iniciais da Escola Estadual Mariano Azevedo .

\section{Mylani Nathalini Dantas Costa}

Mestranda em Ciências da Linguagem ? UERN. Graduada em Letras Língua Inglesa na Universidade do Estado do Rio Grande do Norte? UERN. Graduada em Licenciatura em Matemática pela Universidade Federal Rural do Semi Árido ? UFERSA. Cursou o curso de Extensão Universitária em Língua Inglesa no Núcleo de Ensino e Estudo de Línguas? NEEL (Nível 10) - UERN. Possui experiências como docente de língua inglesa, alfabetização de Jovens e Adultos ? EJA, Professora Mediadora a distância e Presencial - IFRN, UFRN e UFERSA e Assistente à Docência ? CAPES. Participou do programa de iniciação à docência na área de tecnologia. Atualmente é colaboradora e pesquisadora em projetos de extensão e pesquisa com ênfase nas áreas de ensino, linguística, fonética e fonologia da língua inglesa.

\section{Neferson Barbosa da Silva Ramos}

Mestrando em Educação Matemática e Tecnológica (EDUMATEC/ UFPE). Licenciado em Pedagogia, Especialista em Gestão da Educação e Coordenação. Especialista em Arte e Tecnologia pela Universidade Federal Rural de Pernambuco (UFRPE). Atualmente professor do Centro Universitário Brasileiro (UNIBRA), Design Instrucional bolsista do Hospital das Clínicas UFPE. Pesquisador do Laboratório de Pesquisa e Prática - Educação, Metodologias e Tecnologias EDUCAT (UFPE/CNPq). Participa do Projeto de Extensão Proi-Digital Espaço de Criação para Inclusão da Cultura Digital e Maker. Pesquisa sobre Metodologias Ativas, Educação Online e Coreografias Didáticas. Foi professor EAD do Instituto Federal de Pernambuco (IFPE), experiência docente na Educação Infantil e Educação Fundamental nas escolas da Prefeitura do Recife. Foi Assessor de Coordenação do Centro Universitário Joaquim Nabuco-Paulista e Coordenador de Pós-graduação MBAs. 


\section{Nelson Luis Eufrasio Junior}

Mestre em Educação pela Unisinos. Especialista em Informática Educativa pela PUCRS. Graduado em Pedagogia hab. Multimeios e Informática Educativa pela PUCRS e em Séries Iniciais pela UCS. Criação e desenvolvimento de projetos em Educação Continuada (presencial e online), Educação Técnica-profissionalizante e Educação Corporativa. Pesquisa design educacional, design thinking, tecnologias digitais, educação a distância, educação online, materiais didáticos, ensino híbrido e formação de professores. Experiência em formação inicial e continuada de professores, acompanhamento pedagógico docente e mediação tecnológica.

\section{Querte Mehlecke}

Pós-Graduação em Informática na Educação a Distância, UFRGS e Doutorado em Informática na Educação pela Universidade Federal do Rio Grande do Sul, UFRGS. Realizou estágio de doutorado na Universidade Aberta, Lisboa, Portugal. Realizando o Pós-doutorado na Universidade Federal de Pernambuco - UFPE; EDUMATEC; Grupo de Pesquisa EDUCAT; Laboratório de Pesquisa e Prática; Educação, Metodologias e Tecnologias (UFPE/CNPq). Professora das Faculdades Integradas de Taquara - FACCAT, Taquara, RS. Tutora dos Cursos de Pós-Graduação de Mídias na Educação, UFRGS, UAB. Coordenadora do Núcleo de Educação a Distância e Informática Educativa desde 1998. Coordenadora, desde a primeira edição, do 23 Seminário Internacional de Educação, Tecnologia e Sociedade, FACCAT, Taquara, RS. Coordenadora do Projeto do CST em Redes de Computadores, Faculdade IBCMED, Sete Lagoas, MG. Tem experiência na área de Educação, Cursos Superiores presenciais e a distância nas áreas da administração; informática e Hotelaria. Coordena e ministra dos cursos de formação docente para o uso dos recursos tecnológicos em sala de aula para professores universitários. Coordena e ministra cursos de extensão para Tutores, Capacitação pedagógica para EaD; produção de materiais didáticos para EaD. Ênfase em Educação a Distância, atuando principalmente nas seguintes áreas: tecnologias de informação e comunicação; educação a distância, mídias digitais; sistemas de informação, tecnologias educacionais, informática na educação, metodologias e processos de avaliação presencial e a distância; desenvolvimento de objetos de aprendizagem; desenvolvimento e implementação de ambientes virtuais de aprendizagem; formação de professores. Avaliadora de cursos de Graduação presencial, a distância e institucional. 


\section{Rafael Lira}

Possui graduação em Sistema de Informação pela Faculdade Integrada do Recife e mestrado em Ciências da Computação pela UFPE. Atualmente é Professor Assistente do curso de Licenciatura em Artes Visuais com ênfase em Digitais da Unidade Acadêmica de Educação a Distância e Tecnologia da UFRPE. Tem experiência na área de produção de material didático, atuando principalmente nas áreas de design, ilustração, animação e tecnologias digitais.

\section{Renata Araújo}

Professora Assistente da Universidade Federal Rural de Pernambuco. Doutora em Educação Matemática e Tecnológica pela Universidade Federal de Pernambuco com doutoramento sanduíche pela Universidade Aberta de Portugal. Mestre em Educação Matemática e Tecnológica/UFPE, Especialista em Psicologia na Educação/UFPE e Licenciada em Pedagogia. Atuação em pesquisa na área de Educação e com os seguintes temas: tecnologias e educação, educação a distância, cibercultura e educação online, avaliação da aprendizagem online e formação docente na cibercultura. Tem capítulos escritos no livro de 10 anos da EAD/UFRPE e da Série EAD em debate, no volume 3. Livro publicado em ebook resultante de sua dissertação de mestrado intitulado "A interatividade como processo na avaliação da aprendizagem na educação online".

\section{Roges Horácio Grandi}

Mestre e Bacharel em Ciência da Computação pela UFRGS. Arquiteto de Sistemas do Serviço Federal de Processamento de Dados (SERPRO). Atuou como professor de graduação e pós-graduação de tecnologia e gestão na Estácio FARGS (2001-2017). Professor convidado da pós-graduação da IMED Passo Fundo e do SENAC Passo Fundo.

\section{Rosangela Gonçalves dos Santos}

Possui graduação em Licenciatura em Pedagogia pela Universidade Estadual do Rio Grande do Norte (1996) Pós Graduada em Supervisão Escolar e Gestão Escolar, Curso de Formação de Profissionais de Educação em PROEJA FIC e Curso de Formação de Gestores e Supervisores em PROEJA-FIC oferecido pelo Instituto Federal de Educação, Ciência e Tecnologia do Rio Grande do Norte; Curso de Formação para Professores/Tutores em Educação à Distância oferecido pelo Núcleo de Educação à Distância da Universidade Federal 
do Semi Árido. Tem experiência na área de Educação, com ênfase em Docência na Educação Básica e Docência no Ensino Superior no Curso de Licenciatura em Pedagogia na Faculdade Integrada do Brasil, Instituto de Ensino Superior Múltiplo e Universidade Anhanguera; Atuando também como Tutora no NEAD/UFERSA - Núcleo de Educação à Distância da Universidade Federal do Semi Árido nos Cursos de Licenciatura em Computação e Licenciatura em Matemática; Tutora e Co Orientadora no Curso: A Escola e a Cidade: Políticas Públicas Educacionais. Ampla experiência em Supervisão e Coordenação Pedagógica; e Gestão Educacional. Desenvolve a Função de Supervisora Pedagógica, atualmente lotada na Secretaria de Educação do Município de Areia Branca/RN

\section{Ulisses de Melo Furtado}

Mestre em Ciência da Computação pela Universidade Federal Rural do Semi-Árido (UFERSA) e Universidade do Estado do Rio Grande do Norte (UERN) em 2014; Especialista em Mídias na Educação pela UERN em 2013; Graduado em Sistemas de Informação pela Faculdade de Ciências e Tecnologia Mater Christi em 2011 (Bolsista do Prouni); Atuo como Gerente de Redes e Ambientes Virtuais administrando o Ambiente Virtual de Aprendizagem no Núcleo de Educação a Distância (NEaD) da UFERSA; Professor do Curso Técnico de Nível Médio Integrado em Informática da Rede Estadual de Educação do Rio Grande do Norte, além atuações como Suporte de Rede, Professor Formador, Professor Conteudista e Tutor a Distância. Tenho experiência em Tecnologias da Informação e Comunicação (TICs); Formador/Tutor do Programa Nacional de Formação Continuada em Tecnologia Educacional; Desenvolvimento Web, atuando na 'área pública de ensino e administrativa; Professor de Ensino Fundamental, Técnico e Superior; áreas relativas a TICs, Educação a Distância (EaD), Gestão e Inclusão Digital de Professores, além de Administração Pública. 